UNIVERSIDADE DE SÃO PAULO (USP)

ESCOLA DE COMUNICAÇÕES E ARTES

EMERSON ADRIANO GOMES VASCONCELOS

MAGDALENA LÉBEIS E O REGISTRO SISTEMÁTICO DE UM PROCESSO PEDAGÓGICO: RESGATE HISTÓRICO E ANÁLISES INICIAIS

São Paulo

2012 
EMERSON ADRIANO GOMES VASCONCELOS

MAGDALENA LÉBEIS E O REGISTRO SISTEMÁTICO DE UM PROCESSO PEDAGÓGICO: RESGATE HISTÓRICO E ANÁLISES INICIAIS

Dissertação apresentada ao Programa de Pós-Graduação em Música, Área de Concentração: Processos de Criação Musical, da Escola de Comunicações e Artes da Universidade de São Paulo, como exigência parcial para obtenção do título de Mestre em Música, sob a orientação da Profa. Dra. Silvia Maria Pires Cabrera Berg.

São Paulo

2012 
EMERSON ADRIANO GOMES VASCONCELOS

\section{MAGDALENA LÉBEIS E O REGISTRO SISTEMÁTICO DE UM PROCESSO PEDAGÓGICO: RESGATE HISTÓRICO E ANÁLISES INICIAIS}

Dissertação apresentada ao Departamento de Música da Escola de Comunicações e Artes da Universidade de São Paulo e aprovada como exigência parcial para obtenção do título de Mestre em Música pela banca examinadora.

Profa. Dra. Silvia Maria Pires Cabrera Berg (orientadora)

São Paulo, de de 2012 


\section{AGRADECIMENTOS}

A Lenice Prioli, pelos preciosos ensinamentos musicais e artísticos e pela amizade.

A Paulo Bomfim, sobrinho de Lébeis, pelas entrevistas e pelo contato dos demais sobrinhos herdeiros do patrimônio intelectual deixado por Lébeis.

A Luis Roberto Severo Lébeis, Vera Cecília Dias Motta e José Carlos Dias (sobrinhos de Magdalena Lébeis).

A Silvia Maria Pires Cabrera Berg (minha orientadora).

A Fábio Pellegatti (editor dos exemplos musicais).

A Adriana Bairrada e Vinicius Oliveira (revisores do texto).

A Aloysio L. Nogueira, Antonio D. Teixeira, Edson Marçal de Assis, Eliana Alcoba, Jackson C. Oliveira, Jéssica Barreto, Maria Antonia da Silva, Maria Valéria R. Sostena, Milton Rodrigues Moraes, Osvaldo Vanderlei Ascânio e Vivian T. Costa (funcionários da Discoteca Oneyda Alvarenga).

A Isabel Grau (Bibliotecária da Uniro).

Aos amigos Daniela Skromov de Albuquerque, Gil Veloso, Maíra Portugal, Marcelo Aquino, Marcio Junji Sono, Maria Emília Moura Campos, Miranda Bartira Souza, Priscila Priondi e Valter Pinheiro.

A minha mãe e aos meus sobrinhos, pelo grande carinho. 


\section{RESUMO}

Magdalena Lébeis registrou sistematicamente em seis cadernos de aulas, durante um período compreendido entre 1937 e 1955, as 1006 aulas de canto que fez com Vera Janacópulos. Este trabalho traz a transcrição completa dos manuscritos do vol. 1 dos Cadernos de Aulas de Canto de Magdalena Lébeis. Propõe análises iniciais a propósito da abordagem, tanto de Lébeis, quanto de Janacópulos, de elementos técnicos e interpretativos no estudo do canto, contidos no relato sistemático, de próprio punho, de Lébeis, utilizando diferentes fontes da bibliografia sobre pedagogia vocal e especialmente os conceitos expressos por Richard Miller. Procurou-se também contextualizar o desenvolvimento da carreira de Lébeis nas questões sócio-musicais que orbitavam no cenário musical paulistano, durante os anos contemplados pelo depoimento manuscrito de Magdalena Lébeis. Optou-se pela não sistematização das análises, por se entender que seriam necessárias ferramentas de análise adequadas, cujo desenvolvimento pertenceria a outro projeto de estudo.

Palavras-chave: Magdalena Lébeis, Vera Janacópulos, Pedagogia Vocal, Processos Pedagógicos, Técnica Vocal, Interpretação, Canção de Câmara Brasileira. 


\begin{abstract}
Magdalena Lébeis systematically recorded in six notebooks the content of 1006 singing lessons that she took with Vera Janacópulos between 1937 and 1955 . This paper presents the first volume of the manuscripts Cadernos de Aulas de Canto de Magdalena Lébeis. It proposes an initial analysis of how Lébeis as well as Janacópulos approached the technical and interpretive elements in the study of singing which is thoroughly described in Lébeis's account. Besides her manuscripts we have also made use of a considerable literature on vocal pedagogy and especially the concepts expressed by Richard Miller. We also sought to contextualize Lébeis career development within the social and musical scene that was revolving in São Paulo back then. It has been opted for a non-systematic analysis because we understand that a different one would require appropriate and diverse arguments and that would belong to another project.
\end{abstract}

Key-words: Magdalena Lébeis, Vera Janacópulos, Vocal Pedagogy, Pedagogical Processes, Vocal Technique, Interpretation, Song of Brazilian Chamber. 


\section{LISTA DE FIGURAS}

Fig. 1 - Dedicatórias manuscritas dos autores: Dinorá de Carvalho, Guilherme de Almeida e Alfredo Mesquita, coleção Magdalena Lébeis.

Fig. 2 - Diário de São Paulo, por Maurício Loureiro Gama, em 07/05/42.

Fig. 3 - Parte do programa extraída por Lébeis, terceiro caderno de aulas, p.219.

Fig. 4 - Recorte compilado por Lébeis, terceiro caderno de aulas, p. 257.

Fig. 5 - Primeiro recital solo, quarto caderno de aulas, p. 6.

Fig. 6 - Programa compilado por Lébies, quarto caderno de aulas, p. 277.

Fig. 7 - Programa compilado por Lébies, quarto caderno de aulas, p. 277.

Fig. 8 - Quinto caderno de aulas, p. 3.

Fig. 9 - Quinto caderno de aulas, p. 44 e 45.

Fig. 10 - Quinto caderno de aulas, p. 93.

Fig. 11 - Quinto caderno de aulas, p. 136.

Fig. 12 - Carta original digitalizada, assinada por Villa-Lobos, coleção Magdalena Lébeis.

Fig. 13 - Sexto caderno de aulas, p. 67.

Fig. 14 - Foto original digitalizada, sexto caderno de aulas, p. 87.

Fig. 15 - Programa de inauguração da Rádio Eldorado e recorte de do jornal "O

Estado", sexto caderno de aulas, p. 100-101.

Fig. 16- Lébeis, CML-15, p. 22.

Fig. 17 - Lébeis, CML-15, p. 23.

Fig. 18 - Lébeis, CML-15, p. 24.

Fig. 19 - Lébeis, CML-15, p. 25.

Fig. 20 - Lébeis, CML-15, p. 29.

Fig. 21 - Lébeis, CML-15, p. 31.

Fig. 22 - Lébeis, CML-15, p. 35.

Fig. 23 - Lébeis, CML-15, p. 49.

Fig. 24 - Lébeis, priemiro caderno de aulas, p. 17.

Fig. 25 - Página digitalizada do primeiro caderno de aulas, referente a aula de número 37. 
Fig. 26 - Lébeis, quinto caderno de aulas, p. 80.

Fig. 27 - Lébeis, quinto caderno de aulas, p. 83.

Fig. 28 - Lébeis, quinto caderno de aulas, p. 80.

Fig. 29 - Lébeis, quinto caderno de aulas, p. 81.

Fig. 30 - Lébeis, quinto caderno de aulas, p. 83.

Fig. 31 - Lébeis, quinto caderno de aulas, p. 111.

Fig. 32 - Lébeis, quinto caderno de aulas, p. 112, 113.

Fig. 33 - Lébeis, quinto caderno de aulas, p. 114, 115. 


\section{LISTA DE EXEMPLOS MUSICAIS}

Ex. 1 - Exercício proposto na $4^{\mathrm{a}}$ aula.

Ex. 2 - Exercício proposto $91^{\mathrm{a}}$ aula.

Ex. 3 - Exercício proposto na $65^{\mathrm{a}}$ aula.

Ex. 4 - Exercício proposto na $16^{\mathrm{a}}$ aula.

Ex. 5 - Exercício proposto na $37^{\mathrm{a}}$ aula.

Ex. 6 - Exercício proposto na $43^{\mathrm{a}}$ aula.

Ex. 7 - Exercício proposto na $52^{\mathrm{a}}$ aula.

Ex. 8- Exercício proposto na $52^{\mathrm{a}}$ aula.

Ex. 9 - Exercício proposto na $102^{\mathrm{a}}$ aula.

Ex. 10 - Segundo caderno de aulas, p. 268.

Ex. 11- Terceiro caderno de aulas, p. 21.

Ex. 12 - CML - Trecho de "Na minha terra tem".

Ex. 13 - CML - Trecho de "Toada p'ra você".

Ex. 14 - CML - Trecho de "Toada p'ra você".

Ex. 15 - CML - Trecho de "Toada p'ra você".

Ex. 16 - CML - Trecho de "O doce nome de você".

Ex. 17 - CML - Trecho de "O doce nome de você".

Ex. 18 - CML - Trecho de "O doce nome de você".

Ex. 19 - CML - Trecho de "O doce nome de você".

Ex. 20 - CML - Trecho de "O doce nome de você".

Ex. 21 - CML - Trecho de "O doce nome de você".

Ex. 22 - CML - Trecho de "O doce nome de você".

Ex. 23 - CML - Trecho de "O doce nome de você".

Ex. 24 - CML - Trecho de "O doce nome de você". 


\section{LISTA DE ABREVIATURAS}

ABM Academia Brasileira de Música

APM Academia Paulista de Música

CML Coleção Magdalena Lébeis

TBC Teatro Brasileiro de Comédia

EAD Escola de Arte Dramática 


\section{SUMÁRIO}

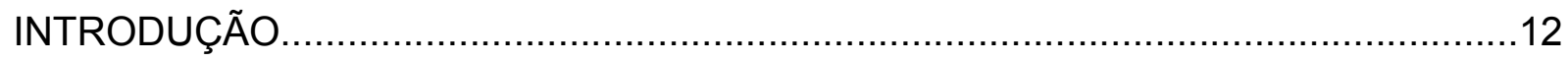

CAPÍTULO 1: Aspectos Biográficos e Contexto Histórico............................................14

1.1. Magdalena Lébeis e o Solar dos Lébeis..........................................................15

1.2. A Opção pelo Canto: “Noite de São Paulo" .......................................................16

1.3. Vera Janacópulos: da disciplina ao reconhecimento........................................18

1.4. Vera Janacópulos numa São Paulo efervescente...........................................23

1.5. O Encontro de Magdalena Lébeis com Vera Janacópulos..................................28

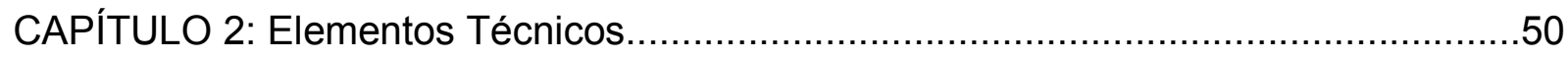

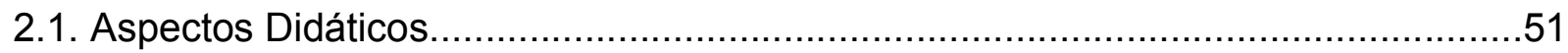

2.2. Elementos Técnicos - Respiração e Apoio......................................................57

CAPÍTULO 3: Elementos Interpretativos ........................................................

3.1. TAVARES, Heckel: Saudade, Minha Terra tem .............................................. 71

3.1.1. LORENZO FERNANDEZ, Oscar: Toada p'ra você.............................................74

3.1.2. MIGNONE, Francisco: O doce nome de você................................................77

3.1.3. CAMARGO GUARNIEIRI, Mozart: A Serra do Rola Moça...................................80

3.1.4. VILLA-LOBOS, Heitor: Poema de Itabira....................................................83

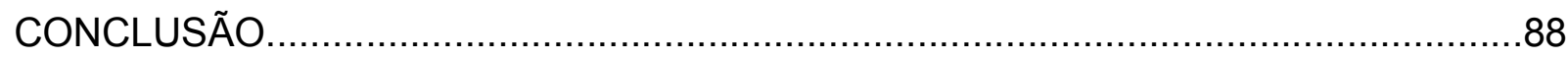

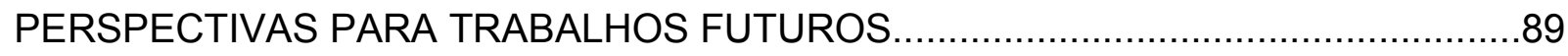

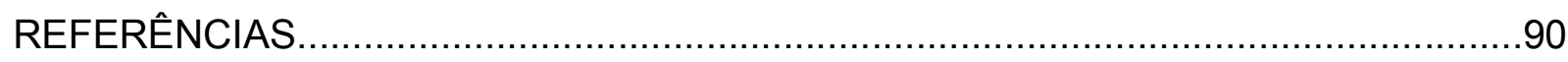

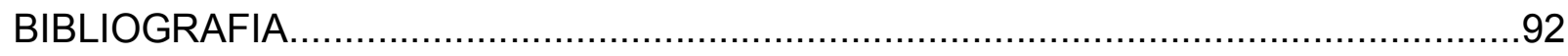

ANEXO I - Cadernos de Aulas de Canto v. 1 - Transcrição Integral.............................94 


\section{INTRODUÇÃO}

Magdalena Lébeis (1912-1984), cantora e professora de canto paulista estudou canto com Vera Janacópulos (1892-1955) durante 17 anos, no período compreendido entre 1937 e 1955, e registrou, de próprio punho, em seis Cadernos de Aulas de Canto, mil e seis aulas.

O acervo Magdalena Lébeis depositado no Centro Cultural São Paulo, contém, além dos cadernos de aulas, uma coleção de partituras com 982 itens, entre os quais se encontram obras manuscritas, obras anotadas por Lébeis, obras autografadas por seus respectivos compositores e dedicadas a Lébeis, e ainda edições raras, especialmente aquelas de música brasileira.

Há também outros 23 itens no acervo, entre os quais, 13 artigos escritos por Lébeis, textos relacionados à interpretação do canto, 34 fotos que documentam diferentes fases da carreira de cantora e professora, a relação de assinaturas dos ouvintes dos Cursos Públicos de Interpretação do Canto, ministrados por Lébeis, e a compilação datiloscrita de toda a crítica musical produzida sobre a carreira de Lébeis, durante cerca de 20 anos.

O ineditismo e a riqueza das informações dos registros sistemáticos de Lébeis, a projeção alcançada por Janacópulos e Lébeis no meio musical, tanto pela divulgação de música do século $X X$, quanto pelas estreias de obras inéditas do repertório nacional e internacional, assim como pelo trabalho pedagógico e pela atuação expressiva em importantes instituições culturais brasileiras, tais como a EAD - Escola de Arte Dramática da USP, o TBC - Teatro Brasileiro de Comédia, as Rádios Gazeta, Eldorado, Nacional, Roquete Pinto e a Sociedade de Cultura Artística, foram os principais fatos que motivaram e justificaram o desenvolvimento do trabalho.

O processo pedagógico relatado por Lébeis é estruturalmente embasado pela formação técnica e pela formação artística ou interpretativa, faz uso de um repertório canônico no princípio do desenvolvimento técnico-vocal, prioriza o repertório de câmara e de concerto e destaca obras brasileiras e do repertório do séc. XX, inclusive em primeiras audições. 
Diante do volume dos registros de Lébeis, se fez necessária uma escolha direcionada por uma triagem que se estabeleceu da seguinte maneira: foram analisados apenas elementos técnicos contidos no primeiro caderno de aulas, ou seja, no período de 1937, 1938 e 1939, onde estão compreendidas as primeiras 124 aulas que, constituem o embasamento técnico do processo pedagógico percorrido por Lébeis.

Sobre os elementos interpretativos analisados no terceiro capítulo, estes foram extraídos de uma triagem apenas sobre o repertório brasileiro trabalhado em aulas por Lébeis, e que, procurou destacar obras que fornecessem um maior número de informações acrescentadas por Lébeis, como anotações de aulas, partituras anotadas e gravações.

Para as análises dos segundo e terceiro capítulos, foram usadas diferentes referências da produção bibliográfica sobre pedagogia vocal, mas, principalmente a produção do pedagogo Richard Miller.

Entendeu-se também ser necessária a realização de um resgate de memória artística de Magdalena Lébeis, contextualizado pelas questões sócio-musicais nas quais orbitavam as carreiras de Janacópulos e Lébeis, assunto que foi exposto no primeiro capítulo e que, teve como referências, um levantamento bibliográfico, além de entrevistas com Paulo Bomfim, sobrinho de Lébeis, e com Lenice Prioli, aluna de Lébeis.

A transcrição integral do volume de número 1 dos Cadernos de Aulas de Canto, que, como os demais, permanecia inédito, foi anexada a dissertação, que também contém imagens diversas como suporte ao texto.

O encontro com Paulo Bomfim, propiciou o contato com os demais sobrinhos herdeiros do patrimônio intelectual deixado por Lébeis, o que resultou na permissão para o trabalho com os manuscritos (visto que não estão em domínio público). 


\section{CAPÍTULO 1: Aspectos Biográficos e Contexto Histórico.}

"Magdalena Lébeis nasceu sob o signo da arte"1, assim escreveu o poeta Paulo Bomfim. Formada em piano sob orientação de Marieta Lion, Lébeis estudou também com Furio Franceschini e com Mademoiselle Burron, chegando a se apresentar como pianista. Em 1937 iniciou uma rotina de aulas de canto com Vera Janacópulos que duraria até 1955. Uma das maiores intérpretes da época, Janacópulos possuía prestígio internacional, era uma artista solicitada por compositores como Stravinsky, Prokofiev, Falla, Milhaud, Poulenc e pioneira na divulgação internacional da obra vocal de VillaLobos.

Lébeis cantou na inauguração da Rádio Eldorado, fez parte da programação da Rádio Gazeta, foi regida por Souza Lima e acompanhada por Fritz Jank em concertos periódicos, atuou regularmente, de 1940 a 1960, na programação da Sociedade de Cultura Artística, cantando no concerto de inauguração do Teatro Cultura Artística, que, aliás, ilustra o patamar alcançado por Lébeis como intérprete do Modernismo Brasileiro.

Ao longo dos anos, Lébeis não somente registrou com afinco as aulas feitas com Janacópulos, especificando data, local e conteúdo técnico e artístico estudado (para se ter uma idéia, no primeiro dos seis cadernos de aulas há quase trezentos exemplos em pauta musical, de exercícios e de trechos do repertório), mas também documentou a carreira com os programas de concerto e críticas publicadas na imprensa, além de fotos e cartas.

Com uma carreira dividida com a pedagogia, ela acumulou um valioso acervo de partituras, muitas delas copiadas à mão da coleção Vera Jancópulos, hoje pertencente a Unirio, mas que esteve aos cuidados de Lébeis durante algum período ${ }^{2}$, em sua casa em São Paulo. Importante salientar a raridade do acervo Vera Janacópulos, descrito no artigo A música do século XX no acervo Vera Janacópulos, Lago (1999).

\footnotetext{
${ }^{1}$ Frase extraída de texto de Bomfim escrito para a "Exposição de partituras, fotos e documentos de Magdalena Lébeis", realizada no Centro Cultural São Paulo, em 29 de novembro de 1988.

2 "Na ocasião da guerra de 1940 guardei em minha casa - desde que Janacópulos mudou-se para o Rio, - todas as partituras da minha grande Mestra. Naquela ocasião, tirei muitas cópias de melodias interamente inéditas que não poderia obter, caso não fosse Janacópulos confiar e haver, na época o copista Lorenzo Cella que a mão nos dava páginas mais claras que as próprias músicas impressas." (LÉBEIS, s. d. 6 p. Artigo (CML Doc. 23/3)
} 


\section{1. - Magdalena Lébeis e o Solar dos Lébeis.}

O ambiente familiar no qual Lébeis nasceu, em 1912, era extremamente favorável para o desenvolvimento de um artista. Seus pais, Sebastião Lébeis e Elisa de Magalhães Lébeis, organizavam no solar da família, situado à Rua Rego Freitas, serões literários, primeiro sob a liderança de Carlos e Cecília, irmãos de Magdalena Lébeis, depois sob a condução dela própira. Neles se apresentavam tanto os principais artistas que viviam em São Paulo como também aqueles que passavam pela cidade. Olavo Bilac, Vicente de Carvalho (este, segundo Alberto Prado Guimarães, chegou a escrever uma peça para ser representada no Solar). Guiomar Novaes - cuja casa se localizava em frente ao solar dos Lébeis -, Mário de Andrade, Guilherme de Almeida, além de personalidades como Assis Chateaubriant, figuravam entre os frequentadores dos saraus. Em sessão da Academia Paulista de Letras, Alberto Prado Guimarães fez um pronunciamento sobre os Lébeis, publicado em 22 de Outubro de 1978 pelo Diário Popular, revelando em detalhes a árvore genealógica da família, com o contexto social no qual estavam inseridos os seus membros, e fazendo considerações a respeito deste antigo salão da Pauliceia.

Guimarães também citou os nomes de Ernani Braga, Helena de Magalhães Castro, Tácito de Almeida, Cleomenes Campos, Paulo Setúbal, Noemia Nascimento Gama, Martins Fontes, Catulo da Paixão Cearense, Narbal e Epíteto Fontes, Edith e Maria da Gloria Capote Valente, Ivone Daumerie, Felix Otero, Angela Vargas, Afonso Lopes de Almeida, Cyro Costa, Getúlio Paula Santos e Francisco Mignone ${ }^{3}$.

Paulo Bomfim se refere à casa dos avós como "um verdadeiro centro cultural", 4 e, quando indagado sobre a presença de Mário de Andrade nos serões, faz uma revelação que não pode ser desconsiderada: "Mário estava em todos os encontros"5. Ainda que "todos" possa talvez ser uma força expressão, não altera o fato de que a

\footnotetext{
${ }^{3}$ A opção por transcrever todos os nomes citados por Guimarães no corpo do texto se deu devido à constatação da escassez de informações a respeito do assunto e, também, para preservar tais informações para pesquisadores que, por ventura, venham a se interessar pelas atividades musicais nos antigos salões paulistas.

4 Entrevista realizada (na companhia de Lenice Prioli,) com o poeta Paulo Bomfim, sobrinho de Magdalena Lébeis, especialmente para este trabalho de pesquisa, no Palácio da Justiça de São Paulo, em 7 jan. 2011.

${ }^{5}$ Idem.
} 
presença frequente de um intelectual da envergadura do autor de Macunaíma nos indica a efervescência cultural e artística dos saraus.

A rede social da qual Lébeis fazia parte evidentemente facilitou em muito sua aproximação com o meio artístico e lhe proporcionou contatos valiosos para a construção de uma carreira artística. O poder aquisitivo de sua família lhe garantia também a tranquilidade econômica e a possibilidade de se dedicar a uma atividade que não gerasse necessariamente lucros imediatos.

Se, por um lado, o ambiente familiar e social era, no mínimo propício para o desenvolvimento da personalidade artística da cantora e futura educadora, por outro, sem a sua determinação, cuidado e empenho, Lébeis não teria se tornado a artista e educadora que foi.

\section{2. - A Opção pelo Canto: "Noite de São Paulo"}

Antes das aulas com Janacópulos e do desenvolvimento de sua carreira de cantora e educadora, Lébeis já possuía sólida formação musical. Estudou e se formou em piano com Marieta Lion, da escola Chiafarelli; estudou teoria musical com maestro e organista Furio Franceschini, além de ter tido um primeiro contato com o estudo de canto com Mlle. Bouron.

Embora tenha chegado a se apresentar algumas vezes como pianista, em 1936, optou definitivamente pela dedicação ao canto, quando estrelou a peça intitulada Noite de São Paulo, fantasia em três atos de Alfredo Mesquita com música inédita e regência de Dinorá de Carvalho e "palavras" de Guilherme de Almeida. O espetáculo se tratava de uma peça teatral acompanhada por orquestra, na qual Lébeis atuou e cantou "Róseas Flores D'alvorada", uma das Modinhas Imperiais, recolhidas e harmonizadas por Mário de Andrade.

Neste primeiro momento da carreira de Lébeis já podemos observar a estreita relação com a Família Mesquita, proprietária do jornal O Estado de São Paulo. O contato com Alfredo Mesquita e especialmente com Esther Mesquita com o tempo se tornaria constante e definidor dos rumos da carreira da artista, como veremos na 
programação da Sociedade de Cultura Artística, "palco" principal de seus recitais e concertos e, portanto, valoroso ambiente para a projeção de sua carreira.

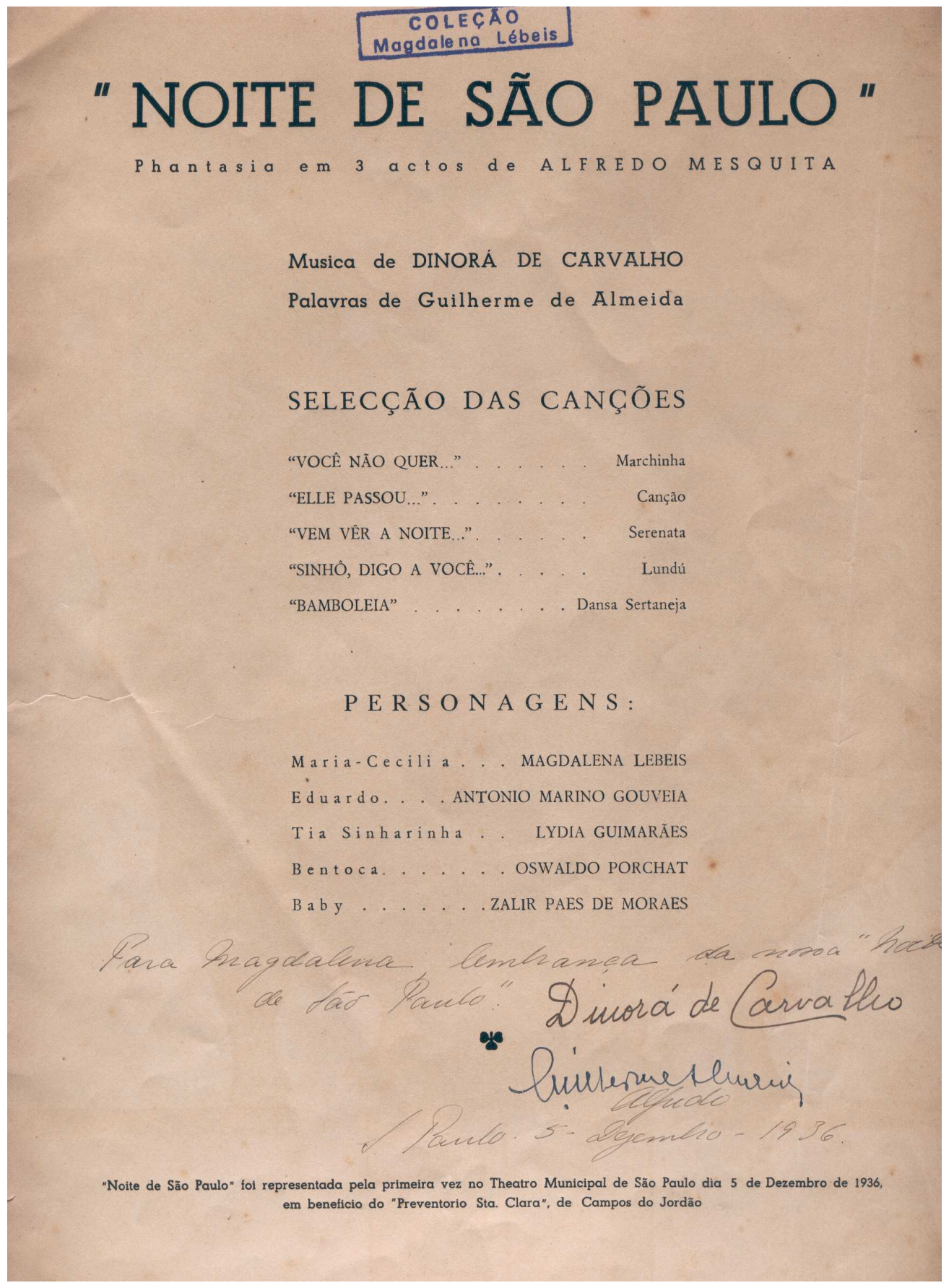

Fig. 1 - Dedicatórias manuscritas dos autores: Dinorá de Carvalho, Guilherme de Almeida e Alfredo Mesquita, Coleção Magdalena Lébeis (CML) 
Foi durante o período de ensaios de Noite de São Paulo que Lébeis conheceu Janacópulos. Um ano e meio depois elas dariam início a um processo de ensino e aprendizagem que duraria 17 anos, ao longo dos quais Lébeis fez o registro sistemático de mil e seis aulas.

Antes de descrevermos detalhadamente esse encontro, entendemos ser necessário apresentar a trajetória artística de Janacópulos e as questões sociais nas quais a carreira dela orbitava.

\section{3. - Vera Janacópulos: da disciplina ao reconhecimento.}

Descontados os elogios hiperbólicos, naturais em uma obra escrita por um ardoroso admirador, pode-se aceitar em Eurico Nogueira França (1959) a asserção de que a cantora ocupava o mais elevado patamar de renome internacional que um artista brasileiro poderia ambicionar na primeira metade do século XX. Além do mais, o papel fundamental que ela teve na implantação e consolidação de importantes instituições culturais brasileiras, como a Escola de Arte Dramática (EAD) da Usp, o Teatro Brasileiro de Comédia (TBC), a Rádio Gazeta e a Sociedade de Cultura Artística, não pode ser tido em menor conta, assim como o pioneirismo com que exerceu a difusão mundial de criações brasileiras.

Radicada em Paris desde os quatro anos de idade, juntamente com a irmã Adriana, que mais tarde se tornaria escultora, Janacópulos iniciou seus estudos em música aprendendo violino com Georges Enesco, a quem Janacópulos costumava, quando mais avançada em anos, creditar acima de todos seus outros mestres, os de canto inclusive, os seus predicados artísticos. Foi ele quem lhe indicou Mme. Reja Bauer como professora de canto, modalidade que ela esperava conciliar com o violino. Se a opção pela arte vocal foi o resultado de sua natural capacidade, os anos disciplinadamente dedicados ao violino não haveriam de ser desperdiçados.

Pois da sua experiência musical de violinista extraiu Vera Janacópulos o acento natural da frase no canto, evitando quer a ausência da inflexão, quer as acentuações bruscas, capazes de fragmentar a linha melódica. (FRANÇA, 1959, p. 13). 
Em 1914, às vésperas do início da Primeira Guerra Mundial, Janacópulos faz sua estréia como cantora em concerto organizado pelo barítono brasileiro Carlos de Carvalho. Pouco depois, um concerto, realizado na Suíça quando ali estavam Vera e Adriana tentando voltar da Bélgica para a França em meio à Grande Guerra recentemente deflagrada. Organizado pelo pianista Lazare Levy e acompanhado por Enesco, o recital a pôs em evidência: ela chegou a ser acompanhada ao piano por seu célebre ex-mestre de violino.

Com seus professores seguintes, Jan de Reszke e Jean Perrier, Janacópulos aprimoraria sua técnica vocal e, com Perrier, principalmente sua expressividade interpretativa, a qual também esperava aperfeiçoar quando se tornou aluna de Lilli Lehmann, na ocasião em que a procurou em Salzburgo para tomar contato mais profundo com a interpretação dos Lieder. Isto não veio a acontecer, porque Lehmann não se atinha às questões interpretativas, mas as lições de controle respiratório e domínio sobre as diversas áreas de ressonância vocal (FRANÇA, 1959, p.15). Lehmann foi uma cantora e professora de projeção internacional, cujo trabalho relacionado à emissão vocal foi pioneiro na elaboração de um esquema gráfico que procurava demonstrar os diferentes níveis de ressonância da voz. Nas primeiras leituras dos cadernos de aulas de canto de Lébeis, podemos observar facilmente que Janacópulos, já na primeira aula, demonstra prioritariamente a preocupação com as questões respiratórias e de ressonância. Lébeis inclusive reproduz o conhecido desenho de Lehmann antecedido do seguinte comentário: "Tenho em seguida uma figura tirada do livro de Lili Lehmann que é justamente o que Dona Vera explica”. Sobre a qualidade expressiva de Janacópulos, diria Gretchaninoff, discípulo de Rimsky-Korsakoff: "você não canta com um, mas com dois corações" (FRANÇA, 1959, p. 53). Tamanha sensibilidade faria, acima de quaisquer outras virtudes, a fama da cantora, como atesta uma crítica publicada pelo The New York Times, em 2 de novembro de 1919.

Frequentadores de recitais às vezes se sentem motivados a reclamar da mesmice, da incapacidade dos cantores de fazer uma canção parecer diferente da outra, e de torná-las todas interessantes. Ninguém que ouviu Vera Janacópulos cantar em seu recital no Aeolian Hall na noite de ontem - e havia muitos ali - teve ocasião de fazer uma reclamação tal. Ela tinha 
uma emoção para cada número que era capaz de impregnar-lo inteiramente dela, e abundantes recursos para burilá-la. (ALDRICH, 1919, não paginado, tradução do autor $)^{6}$

O jornalista ressalta que, apesar de a apresentação da jovem de 26 anos conter algumas deficiências técnicas sua expressividade interpretativa era notável.

Uma nota no mesmo jornal sobre a apresentação de Janacópulos um pouco depois (a nota data de 11 de dezembro) reitera esse caráter em sua presença de palco, então acrescida de detalhes:

Vera Janacopulos, uma soprano greco-brasileira cuja interpretação, antes que propriamente os dons musicais, frequentemente remete à sua compatriota Novaes, ofereceu a última palavra em poesia de tom exótico de Igor Stravinsky ontem no Aeolian Hall - quatro peças que só são canções no nome, foram declamadas no russo de um velho, de mendigos, de uma garotinha e de um coronel, com grotescos apartes de oito acompanhadores em instrumentos de cordas e sopro, que soavam como se estivessem sem palavras para expressar sua admiração. George Barrère levou os músicos assistentes da Sociedade Sinfônica e eles mesmos riram alto com a platéia ruidosa da brincadeira de Stravinsky, ainda que houvesse russos presentes, incluindo Prokofiev, Michel Fokine e outros, que aplaudiram com evidente satisfação.

Senhorita Janacópulos cantou duas novas canções em francês de Jean Huré e diversas peças elaboradas, para as quais seu equipamento vocal é muito delicado, de Duparc e Mussorgsky. (THE NEW YOR TIMES, 1919, não paginado, tradução do autor). ${ }^{7}$

\footnotetext{
${ }^{6}$. Frequenters of songs recital sometimes feel moved to complain of their sameness, of the inability of the singers to make one song seen different from another, and to make them all interesting. Nobody who herd Miss Vera Janacopulos inher recital in Aeolian Hall yesterday afternoon - and many heard her had occasion to make any sucir complaint. She had a thrill for every number that was at all capable of carrying a thrill, and abundant resources for furnishing it.

${ }^{7}$ Vera Janacópulos, a Greek-Brazilian soprano whose interpretative rather than musical gifts often recall her compatriot Novaes, gave the last Word in exotic tone poetry by Igor Stravinsky yesterday at Aeolian Hall for songs in name only, declaiming in Russian of an old man and beggars, a yong girl, a Colorel, with grotesque "asides" from eight commenting players of string and wind instruments, as if without words to express their amazement. George Barrère le assistingplayers from the Synphony Society, and these music ians themselves laughed aloud whit the roaring audience at Styravinsky's merry jets, thouh there were Russians present, including Prokofieff, Michel Fokine and others, who applauded with evident relish.
} 
É interessante notar que Poulenc, por sua vez, considerava Janacópulos uma intérprete "miraculosa" da obra de Mussorgsky (LAGO, p. 3).

As incursões na América do Norte assinalariam a consagração internacional da cantora, que viria a se apresentar por várias salas de concerto de excelência pela Europa e pelo resto do mundo, passando pelo Brasil em 1920 e por algumas ocasiões na década de 1930. Mas a dimensão negativa dos comentários feitos sobre suas qualidades técnicas, em contraste com a veemente admiração que despertaram suas qualidades interpretativas, pode constituir indício de manifestação de um arraigado temor que ela testemunhava abrigar quando se apresentava, desde o momento em que o reconhecimento público a imbuiu de imensa responsabilidade artística, um pavor exasperante que a fazia por vezes torcer por um desastre que a liberasse da performance. Torna-se, assim, inevitável ponderar que, quando a cantora deu o natural passo de se dedicar ao ensino do canto, o fato de ter recorrido a um curiosíssimo expediente pode revelar uma tentativa de sistematizar uma espécie de desprendimento que ela supunha necessário à superação pela voz do tenso peso que decorre da presença em cena: quando inicialmente se lançou no magistério, em Paris, Vera Janacópulos criou um processo pedagógico que envolvia o uso de marionetes.

os bonecos não ficam nervosos. Nos seus destinos de títeres, que uma vontade superior traça, matematicamente, não há lugar para emoções parasitárias, e se alguma hierarquia é necessário estabelecer eles a aceitam com o fatalismo próprio da sua condição de autômatos. Assim, também, já que cantam, são profundamente submissos à música sem a preocupação do efeito a obter. Essa perfeição inumana vale por uma escola de disciplina. E Vera Janacópulos, obtida a colaboração de Joaquim Nin para os arranjos musicais e de Raymond Cid para a cenografia, lançou seu "guignol" com larga variedade de repertório, e profusa fantasia de disposições cênicas, quase sempre, no entanto, baseando o canto e o enredo e, portanto, a trama vivida pelos personagens, no folclore de vários países. (FRANÇA, 1959, p. 44).

Miss Janacopulos sang two novel patter songs in French by Jean Huré and several elaborate pices, for which her vocal equipment is yet slender, by Duparc and Moussorgsky. 
Assim, em vez de recitais penosos, por meio de um processo pedagógico inovador, ela apresentava aos alunos um ambiente talhado para extrair, com o mínimo de tensão, o máximo de expressão, criando situações seguras para que eles pudessem se desenvolver sem traumas; a um só tempo, propunha um exercício de absoluta entrega musical e de superação da apreensão que invade grande parte dos intérpretes antes da presença em palco.

A intensa e estreita relação com compositores contemporâneos, como Prokofiev, Manuel de Falla ${ }^{8}$, Stravinsky, Poulenc e Villa-Lobos - de quem Vera seria um dos maiores intérpretes divulgadores na Europa e América, senão o maior, juntamente com Rubinstein; Lago (1999, p. 4) menciona uma dedicatória feita por Villa-Lobos, em que ele diz: "a maior artista que conheço e a melhor intérprete das minhas obras" -, e o amor por Debussy, que, ao contrário do que se supõe, ainda não era tão célebre e popular (mas viria a ser, também graças à ampla repercussão da interpretação de Vera à Colloque Sentimental), denotam que a cantora era dotada de um espírito artístico inovador, ligado a seu tempo e colocava seus dotes artísticos a serviço de uma grande parcela de repertório que não o convencional ou consagrado.

A utilização dos títeres como ferramenta pedagógica ilustra seu caráter inventivo. Com o guignol, Janacópulos fazia públicas também tiradas satíricas com que ironizava a ópera. Além de ampla repercussão na imprensa, seu método recebeu grande atenção de pessoas de círculos respeitáveis, chegando a ensejar uma conferência feita por Jean Aubry.

Seja como for, nos círculos de maior importância, ou seja, entre os maiores compositores da época com quem Janacópulos privava e/ou tinha papel de destaque na difusão de suas obras, sua relevância era opinião unânime. De acordo com Lago (1999), que realizou uma criteriosa análise do acervo de partituras da cantora, sintetizando a importância que Janacópulos atingira como intérprete destacada de Stravinsky, Prokofiev, Villa-Lobos, Milhaud e Poulenc:

\footnotetext{
${ }^{8}$ A estreitíssima relação que Janacópulos manteve com Manuel de Falla mereceria, decerto, uma mais profunda apreciação. Como a maioria dos compêndios históricos que a citam mencionam o fato de ser ela uma das interpretes favoritas do espanhol, o papel fundamental dela deve ter sido fundamental não apenas na difusão e fixação do repertório cantado do autor, mas também em seu desenvolvimento e compreensão.
} 
entre as numerosas primeiras edições, manuscritos e autógrafos, destacam-se manuscritos originais de obras das quais $\mathrm{VJ}$ realizou primeira audição: de Stravinsky, as instrumentações de 1923 para Pastorale e Tilimbom; de Prokofiev, a orquestração de A Rosa e o Rouxinol; de Milhaud, os Quatro Poemas de Catulo (para voz e violino); de Villa-Lobos, a orquestração de Viola. A presença de uma cópia autógrafa de VillaLobos, datada de 1920, dos Pribaoutki (de Stravinsky) permite novas hipóteses quanto ao conhecimento da música contemporânea no Rio, antes de sua primeira viagem a Paris em 1923; por outro lado, os programas e críticas dos recitais de VJ nos anos 20 trazem algumas precisões a respeito de primeiras audições de obras de Villa-Lobos e na reconstituição dos primeiros concertos com sua música em Paris. A coleção revela duas transcrições para orquestra inéditas e não catalogadas: de Prokofiev, a melodia A Rosa e o Rouxinol de RimskiKorsakov, e de Villa-Lobos a melodia Phidylé de Reynaldo Hahn. Deve ser observado o número e a qualidade excepcionais das dedicatórias autógrafas (Fauré, Ravel, Stravinsky, Roussel, Milhaud, Poulenc, Bloch, Markevitch, Mignone, Mengelberg, Mitropoulos etc.), que constituem testemunho eloquente da posição alcançada por Vera Janacópulos (LAGO, 1999, p. 2).

Cabe mencionar que praticamente todos os compositores citados acima se apresentaram com ela em concerto, como instrumentistas, ou como regentes.

\section{4. - Vera Janacópulos numa São Paulo efervescente.}

O início das atividades docentes de Vera se deu ainda em Paris. França (1959, p. 13), comenta: "Durante a primeira Grande Guerra teve Janacópulos uma discípula americana que, paradoxalmente, a conduziu à sua segunda tutela pedagógica [...]". Também fica claro que o fato se deu na Europa, mas a transição de cantora para professora se completaria simultaneamente à decisão de retornar ao Brasil. Em 1936, instalalou-se em São Paulo e foi contratada pelo Departamento de Cultura do município para lecionar canto, o que não a impediu de imiscuir-se em praticamente todas as 
iniciativas culturais relevantes no período e, na maior parte dos casos indicar como sucessora, sua discípula Lébeis.

Designada para ministrar aulas no Teatro Municipal, Janacópulos fez uma seleção de 110 aspirantes a alunas, para chegar, por fim, a duas turmas de 15 discípulas. Entre estas estava Madalena Lébeis, cujo caderno de aulas de canto assinala o dia 30 de outubro de 1937 como o da primeira aula com Janacópulos.

Apesar da contratação pela prefeitura e do grande impacto que teria na cena local a presença de uma profissional de renome internacional, seria em iniciativas particulares que Janacópulos se veria pela primeira vez em meio a projetos de nível técnico e artístico sem precedentes no panorama paulista e brasileiro. Da primeira dessas iniciativas, a Sociedade de Cultura Artística, ela já participara como intérprete em março de 1920, outubro de 1930, setembro e outubro de 1933, outubro de 1934 e em dezembro de 1937.

Criada em 1912 com a finalidade de estimular a produção e a fruição cultural da cidade de São Paulo, a Sociedade de Cultura Artística tinha em seus programas, nas primeiras décadas, nomes como Arthur Rubinstein, Claudio Arrau, Souza Lima, Guiomar Novaes, Magda Tagliaferro, para citar apenas as celebridades mais frequentes. Inicialmente dedicada a saraus literários, que reuniam intelectuais e escritores como, Graça Aranha, Olavo Bilac, Armando Prado, Amadeu Amaral, Afonso Arinos, Alfredo Pujol, Oliveira Lima, Martins Fontes e Coelho Neto, rapidamente a Sociedade se organizaria para promover na cidade uma programação musical como nunca se ouvira, que incluía também Arnaldo Estrela, Heitor Villa-Lobos, Francisco Mignone, Camargo Guarnieri, Ernani Braga, Henrique Oswald, Lorenzo Fernandes, Mehlich, Bidú Sayão, Eleazar de Carvalho, Furio Franceschini, Luigi Chiafarelli, Fritz Jank.

As atividades da Sociedade se estenderam também para a área teatral e, sob a iniciativa de Alfredo e Esther Mesquita, e de Décio de Almeida Prado, iniciou-se ali uma efervescência produtiva que mais tarde, notadamente em vista do espírito empreendedor de Almeida Prado, que à época já dirigia o Grupo de Teatro Experimental, resultaria na criação do TBC, Teatro Brasileiro de Comédia. 
Estas palavras de Mário de Andrade, citadas em diversos materiais atuais da Cultura Artística testemunham a admiração que o trabalho desenvolvido ali despertaria:

\begin{abstract}
O que determina, em principal, o mérito primeiro e a utilidade magnífica da Sociedade de Cultura Artística é a qualidade musical que ela impõe a São Paulo, se erguendo a pioneira na apresentação dos grandes virtuosos e agrupamentos musicais de celebridade mundial. [...] E se é incontestável que a vida musical paulista ainda se consegue manter numa elevação muito honrosa, ela o deve em parte decisiva ao exemplo e ação da Sociedade de Cultura Artística". Se as sentenças finais carecem de uma atualização corretiva, principalmente no que diz respeito à música, não contradiz, porém, o valor do que foi construído pela iniciativa pioneira. (Disponível em: www.culturaartística.com.br Acesso em:14 jul. 2012)
\end{abstract}

Outro marco da ebulição cultural de São Paulo em meados do século XX seria a criação, por Alfredo Mesquita, de uma escola de arte dramática. Anunciada pelo jornal da família em 18 de abril de 1948, essa iniciativa previa um rol de notáveis encabeçando o corpo docente: lecionando atitude e expressão corporal, a célebre bailarina Chinita Ullmann, precursora da dança-teatro no País; história do teatro, Décio de Almeida Prado; representação de drama, o proprio Alfredo Mesquita; comédia, ninguém menos que Cacilda Becker; dicção e impostação vocal, Janacópulos. A aula inaugural da Escola de Arte Dramática de São Paulo foi proferida por Paschoal Carlos Magno no auditório da Biblioteca Municipal, em maio de 1948. A escola teria diversas moradas: primeiramente numa sala cedida da Escola Elvira Brandão, passaria, no ano seguinte, para o segundo andar do prédio em que funcionava o recém-inaugurado TBC, permanecendo ali por alguns anos. Seguiram-se como sede um casarão na Rua Maranhão e, ao longo da década de 1960, as dependências do Liceu de Artes e Ofícios, na avenida Tiradentes. Como assinala a pesquisa de mestrado de Hecker (2009), Alfredo Mesquita, que creditava sua concepção das artes cênicas ao diretor francês Jacques Copeau, se afirmava inteiramente filiado ao teatro francês - o que pode ter sido muito confortável para Janacópulos.

No trabalho de Guerrini (2004) sobre a Rádio Gazeta, o autor faz a seguinte descrição de outro projeto que, talvez com maior expressividade, tenha sido decisivo 
para a adoção local de uma produção musical que nada ficaria devendo a projetos promovidos por rádios europeias:

Imagine-se uma emissora de rádio comercial no Brasil que mantinha uma Orquestra Sinfônica formada por músicos brasileiros e estrangeiros de altíssimo gabarito e notáveis práticas orquestrais; que dispunha de um coral formado através de concurso público amplamente divulgado; que transmitia um programa semanal onde eram apresentadas, com seu próprio elenco, versões compactadas de grandes óperas, algumas em primeira audição em São Paulo [e no Brasil], e um programa de música sinfônica aos domingos em que se ouviam grandes atrações nacionais e internacionais; que chegou a contratar cantores líricos na Itália; que promovia um concurso de jovens pianistas, patrocinado por uma fábrica de pianos, em que se revelaram alguns talentos que hoje estão entre os grandes nomes do teclado brasileiro; que contava também com um "Jazz", ou big band, que se apresentava várias vezes por semana; e ainda um Jazz Sinfônico, que era a união da big band com a Sinfônica; uma emissora cujo primeiro Diretor Artístico era reverenciado como "o príncipe dos pianistas brasileiros", tendo ganho o primeiro prêmio do Conservatório de Paris, convivido com Ravel e estudado com Madame Debussy; que empregava uma programadora musical de fulgurante carreira internacional como cantora, tendo-se apresentado numerosas vezes com Stravinsky, Prokofiev, de Falla, Villa-Lobos e outros nomes do modernismo musical das primeiras décadas do século $X X$. Imagine-se também que o acesso ao seu auditório era gratuito, e nele podia-se assistir a algumas horas de música ao vivo pelo menos seis dias por semana; que essa emissora era ligada a um jornal que chegou a ser o de maior tiragem em São Paulo, e que the dava constante e extensa cobertura; [...] (GUERRINI, 2006, p. 26)

Tratava-se de modelo de projeto que países desenvolvidos adotaram no mesmo período, a exemplo da Orquestra Sinfônica da Rádio de Viena, fundada em 1969, da Orquestra Sinfônica Tchaikovsky da Rádio de Moscou, da britânica Orquestra Sinfônica BBC, ambas fundadas em 1930, da Orquestra Sinfônica da Rádio Bávara (1949), da Orquestra Sinfônica NHK, do Japão, da Orquestra Sinfônica Nacional Dinamarquesa 
fundada em 1925, e da Orquestra Sinfônica NBC (1937 - 1954), que era conduzida por Arturo Toscanini. A descontinuidade do projeto brasileiro, porém, é de se lamentar. Em especial porque a programação da rádio era dedicada não apenas aos grandes clássicos do repertório tradicional, mas também à música moderna e contemporânea de então, além do jazz e da música popular, incluindo o folclore e o sertanejo, que influenciavam a nova música de câmara e de concerto.

A união de Souza Lima, Janacópulos e Armando Belardi, que viria a suceder Souza Lima na direção da Rádio Gazeta, se mostraria sob medida para a consolidação de uma programação ampla e formadora de público. Souza Lima e Janacópulos estavam atentos à tradição e, ao mesmo tempo, tinham profundo interesse pela produção moderna. Ele se atinha às obras orquestrais e ela, às de câmara. Belardi, por sua vez, assegurava a difusão de um repertório diversificado, uma vez que suas preferências musicais não se concentravam na música moderna da época, fato também importante na diversificação do repertório, contribuíndo para uma melhor educação musical da população, uma proposta da rádio.

Apesar de ter deixado Paris pouco antes do advento da Segunda Grande Guerra e abandonado grande parte de seus pertences, entre eles dois quadros de Picasso, que nunca seria recuperada depois do saque feito ao seu apartamento na invasão alemã de Paris, Janacópulos veio ao Brasil com um conjunto de partituras que certamente ajudou a difundir aqui o repertório que ela conhecia.

Outra contribuição de Janacópulos à programação da Rádio Gazeta, talvez mais sutil, porém decisiva, se deu por intermédio de Mário de Andrade. Enfático nos elogios a essa intérprete (ANDRADE, 1993, p. 245-246), não opôs resistência ao empréstimo à rádio de inúmeros exemplares de discos da Discoteca Pública Municipal (GUERRINI, 2006, p. 30). A discoteca, dirigida por Oneyda Alvarenga, era uma subseção de um outro projeto, que infelizmente não passou de projeto, a Rádio-Escola, que Mário de Andrade e Paulo Duarte tinham em mente.

Vera Janacópulos desenvolveu uma carreira de cantora ligada ao seu tempo e a sua origem, também atuou como professora. Divulgou, e, por muitas vezes, criou em primeiras audições, na Europa, nos Estados Unidos e no Brasil, obras que se tornariam 
célebres para o repertório vocal moderno, além de fazer presente a música brasileira em suas realizações.

\section{5 - O Encontro de Magdalena Lébeis com Vera Janacópulos.}

Em 1937, no ano seguinte à realização de "Noite de São Paulo", Janacópulos, residindo definitivamente em São Paulo, cidade na qual vivera durante oito anos ${ }^{9}$, e contratada pelo Departamento de Cultura, começa a dar aulas para Lébeis. A relação de ensino e aprendizagem entre elas duraria quase duas décadas, chegando ao fim com o falecimento de Janacópulos, em 1955.

A rede social da qual Lébeis fazia parte veio a encaminhar os rumos da sua formação e carreira, e a relação com a Família Mesquita, que, convém ressaltar, já vinha desde seus antepassados ${ }^{10}$, foi determinante também para o encontro dela com Janacópulos. Lébeis, em entrevista para a Folha da Tarde, em 16 de fevereiro de 1981, deu a seguinte resposta ao Ihe perguntarem como a tinha conhecido:

Bem, em 1936, Alfredo Mesquita convidou-me para encenar o papel principal na peça "Noite de São Paulo", que havia escrito, com três apresentações no Teatro Municipal de São Paulo. Diante disso, eu preparei a Modinha Imperial Róseas Flores d'Alvorada, de autor anônimo e recolhida por Mário de Andrade, que cantei sob regência de Dinorá de Carvalho. Vera Janacópulos estava presente em quase todos os ensaios, pois veio ao Brasil a convite da Cultura Artística para com Mário de Andrade formar um coral. Um ano e meio depois, quando perdi meu pai, Esther Mesquita me aproximou de Vera, que me disse: "Se você quiser

\footnotetext{
${ }^{9}$ A informação de que Janacópulos viveu com residência fixa em São Paulo durante oito anos, aqui reproduzida, se deve a França (1959). Nos cadernos de Lébeis, há várias considerações sobre a mudança de Janacópulos para o Rio, mas não a data precisa, provavelmente esta informação esteja entre os documentos do acervo da Uniro. Cabe considerar que a frequência com que ela se dividida entre São Paulo e Rio, mesmo durante os anos de residência em São Paulo, era muito intensa. Isso nos fica claro na leitura dos cadernos, e os períodos de afastamento relativamente longos nos permitem dizer que, de fato, Janacópulos se dividia entre as duas cidades até se fixar definitivamente no Rio de Janeiro.

${ }^{10}$ Guimarães (Diário Popular, 22/10/1978) deixa entrever o vínculo das famílias ao contar o seguinte: "A Família Lébeis tem a sua origem na cidade de Gau-Algesmein [...] Seu patriarca no Brasil foi Guilherme Lébeis que veio para São Paulo em meados do século XIX. Aqui casou-se com D. Escolástica (Sinharinha) de Arruda Botelho, nascida em Itu, em 10 de Janeiro de 1846. Segurando o véu da noiva entrou na Igreja a menina Lucila Cerqueira César que seria futuramente a senhora Julio Mesquita".
} 
cantar para roda limitada, você não precisa estudar, mas se quiser fazer carreira, garanto que nestes cinco anos você conseguirá". "Naquele momento Esther Mesquita torna-se minha madrinha musical e quatro anos depois eu já estreava no Teatro Municipal de São Paulo sob regência de Souza Lima.

Lébeis, desde a primeira até a última aula que teve com Janacópulos, manteve a disciplina de registrar em seis cadernos de aulas de canto, assim ela os intitulou, cada um desses encontros pedagógicos, não de maneira casual, mas sistemática e conscientemente, registrando data e local, numerando as páginas uma a uma, anotando o conteúdo trabalhado e fazendo observações sobre o processo pedagógico que se desenvolvia.

Diante do volume dos registros de Lébeis, seis cadernos de aulas, cada um com aproximadamente trezentas páginas manuscritas, entre outros textos produzidos pela artista, e do vasto período que abrangem, é espantoso o fato de quase não encontrarmos imprecisões ou rasuras, no entanto, no tocante ao número de aulas registradas, esta pesquisa conclui que há, de fato, oitocentas e vinte seis, e não mil e seis. Do registro da aula de número setecentos e nove há um salto para a de oitocentos e à aula de número novecentos antecede a de número oitocentos e nove.

Cabe aqui também esclarecer que Lébeis considerava como aulas também os ensaios e repasses com Jank e Salles, nos quais não necessariamente estaria presente Vera Janacópulos. Não consideramos de relevância determinante fazer um levantamento exato por compreender que a qualidade de um processo pedagógico não se define apenas por uma soma exata de encontros, e sim pela qualidade da orientação do educador e pela capacidade de recepção do educando.

Lébeis rejeitava claramente que se pudesse denominar os cadernos de aulas de "diários": "Este caderno não foi feito para ter o fim de um diário, do que sempre tive horror."11.

\footnotetext{
${ }^{11}$ Frase escrita em 8/04/1942, extraída da página 169, número da paginação original manuscrita, pertencente ao terceiro caderno de aulas de Lébeis. O texto é intitulado como "Observações minhas", título que aparecerá periodicamente, ainda que não em grande número de ocorrências. Normalmente estas "observações", são uma espécie de licença poética, para usar os cadernos de maneira diferente, ou seja, se distanciar um tanto dos registros prioritariamente técnicos, pedagógicos ou estilísticos e dar
} 
Os primeiros anos de estudo com Janacópulos foram dedicados principalmente à formação técnico-vocal, facilitada em muito pela experiência de instrumentista que Lébeis possuía. Janacópulos fazia audições domiciliares durante o período de formação de seus alunos. Lébeis relata detalhadamente esses eventos, que, se não bastasse a finalidade óbvia de expor paulatinamente os discentes ao contato com o público, tinham também uma função de vitrina que revelasse alunos que pudessem seguir carreira. No ano de 1939, ocorreram quatro audições, além de uma apresentação no Teatro Municipal de São Paulo, um concerto a dezesseis vozes regido por Janacópulos. No ano seguinte, outras quatro audições; na segunda delas, em 26 de setembro de 1940, Esther Mesquita fez o primeiro de vários convites a Lébeis para que ela se apresentasse na temporada da Sociedade de Cultura Artística.

Foi hoje um dos dias mais felizes de minha vida! Hei de conservar sempre em minha memória esta data onde alcancei um êxito. Dona Vera deu hoje mais uma audição que foi bem concorrida. Cantei "Jalousie et fierté", "Nanny", "Le Manoir de Rosemonde" e "Mon amour". Cantei do meu gosto como eu desejava cantar; com desenvoltura, voz clara, boa dicção com toda ardência de minh'alma. Ao acabar percebi nos olhos de Dona Vera um sincero contentamento. Ela ficou tão contente que foi por vê-la assim que eu me senti feliz. Fui convidada para um recital no Cultura Artística em Abril ou Maio. Esther Mesquita gostou de ouvir-me prova é que gentilmente me fez este convite. ---- Quem me dera que eu pudesse realizar esse sonho!... Que Deus me proteja! (LÉBEIS, segundo caderno de aulas, 1940, p. 169170)

Em Outubro de 1940 Dinorá de Carvalho também Ihe fizera um convite: "Cantei hoje um programazinho para Dinorá de Carvalho e fui bastante bem. Ela convidou-me para cantar em Janeiro próximo, acompanhada pela orquestra feminina, no Salão Vermelho do Esplanada. Se Deus me ajudar, aceitarei."12 No mesmo mês Lébeis faria uma audição exclusiva para família Mesquita.

vazão a alguma emoção ou um desabafo que não pudesse esperar, todos, porém, sistematicamente anotados como uma ressalva.

${ }^{12}$ Não há registros da realização do concerto. 
Cantei para a Família Mesquita e graças a Deus fui muito bem. Obedeci ao seguinte programa:

Marcello - Quella fiamma, Gluck - O Del mio dolce ardor, Haendel - Ch'io m'ai vi possa, Acis e Galatée, Schubert - Mon séjoour, Jalousie e fierté, Le poleau indicateur, Le Rois des Alunes, Duparc - La vie interieur, Le Manoir de Rosemonde, Chausson - Nanny, Fauré Rencontre e Toujours Ao finalizar o programa cantei a pedido as seguintes musicas:

Duparc - L'invitation au Voyage, Roussel - Le bachelier de Salamanque, Schubert - La poste, Brahms - Mon amour. (LÉBEIS, segundo caderno de aulas, p. 192)

Os episódios acima citados mostram a posição de destaque que Lébeis ocupava. Ao nos debruçarmos sobre o legado documental de Lébeis, perceberemos o quanto ela galgou, passo a passo e com extraordinária disciplina, para obter seus feitos artísticos, porém o prestígio de Janacópoulos, suas relações sociais e artísticas, bem como os próprios contatos de Lébeis, desde os saraus do solar dos Lébeis, foram relevantes para que ela pudesse expressar a sua verve.

Seguem-se periódicas, durante 1941 e 1942, as aulas com Janacópulos e as audições domésticas que antecederam o primeiro concerto para a Sociedade de Cultura Artística. Além do conteúdo técnico e do repertório, chamam a atenção a autonomia crítica e a severidade com a qual Lébeis se refere às aulas que foram acompanhadas por Camargo Guarnieri em 1941:

A lição de hoje foi acompanhada por Guarnieri. Dei pela primeira vez "La vague et la cloche" de Duparc, musica dificílima de interpretar e de cantar. O acompanhamento, que é completamente desvairado atrapalhou-me bastante porque o Guarnieri, embora vibrátil e bom conhecedor de música, embrulhou bastante. (LÉBEIS, segundo caderno de aulas, 1941, p. 261)

A capacidade artística de Lébeis seria verbalmente reconhecida por Janacópulos no mesmo ano: "Magdalena eu preciso me confessar que sou sua fã" Você, quando canta me emociona! Estou comovida! Estou orgulhosa de você! E... o que eu senti não posso e nem sei descrever...." (LÉBEIS, segundo caderno de aulas, p. 290) 
A severa crítica a Guarnieri, como acompanhador, ocorre novamente. Optamos por transcrevê-la, não por qualquer característica que pudesse ser interpretada como pitoresca ou anedótica, e sim pela revelação da relação multifacetada que havia entre a discípula, Janacópulos e o compositor.

Guarnieri estava meio louco. Raras vezes ele me acompanhou no tom em que eu estava cantando. Fez umas modulações, umas progressões realmente diabólicas. Pobre Schumann!... (LÉBEIS, terceiro caderno, 1942, p. 132)

Mais dois episódios ilustram a relação dela com personalidades de influência social e artística, como Mário de Andrade, Assis Chateaubriant e Guilherme de Almeida.

A família de tio Valdomiro ofereceu-me uma recepção. Havia bastante gente e todos me aplaudiram calorosamente. Assis Chataubriant levou um repórter do Diário de São Paulo e, pelo que me parece, amanhã ou depois sairá uma crônica nesse jornal. Cantei sem fazer programa e, modéstia à parte alcancei sucesso e propaganda futura Graças a Deus. [...]

Cantei numa reunião aqui em casa para algumas pessoas da imprensa. Veio o senhor Lívio Xavier, critico musical do Diário de São Paulo; Mário de Andrade, Correia Junior e Senhora também compareceram. Fui felicíssima e todos apreciaram bastante, Graças a Deus. (LÉBEIS, 1942, terceiro caderno de aulas, p. 192-206)

Dois dias depois, a critica escrita pelo jornalista de Chataubriant relataria aquela audição particular e faria a "propaganda" do concerto para a Sociedade de Cultura Artística. 


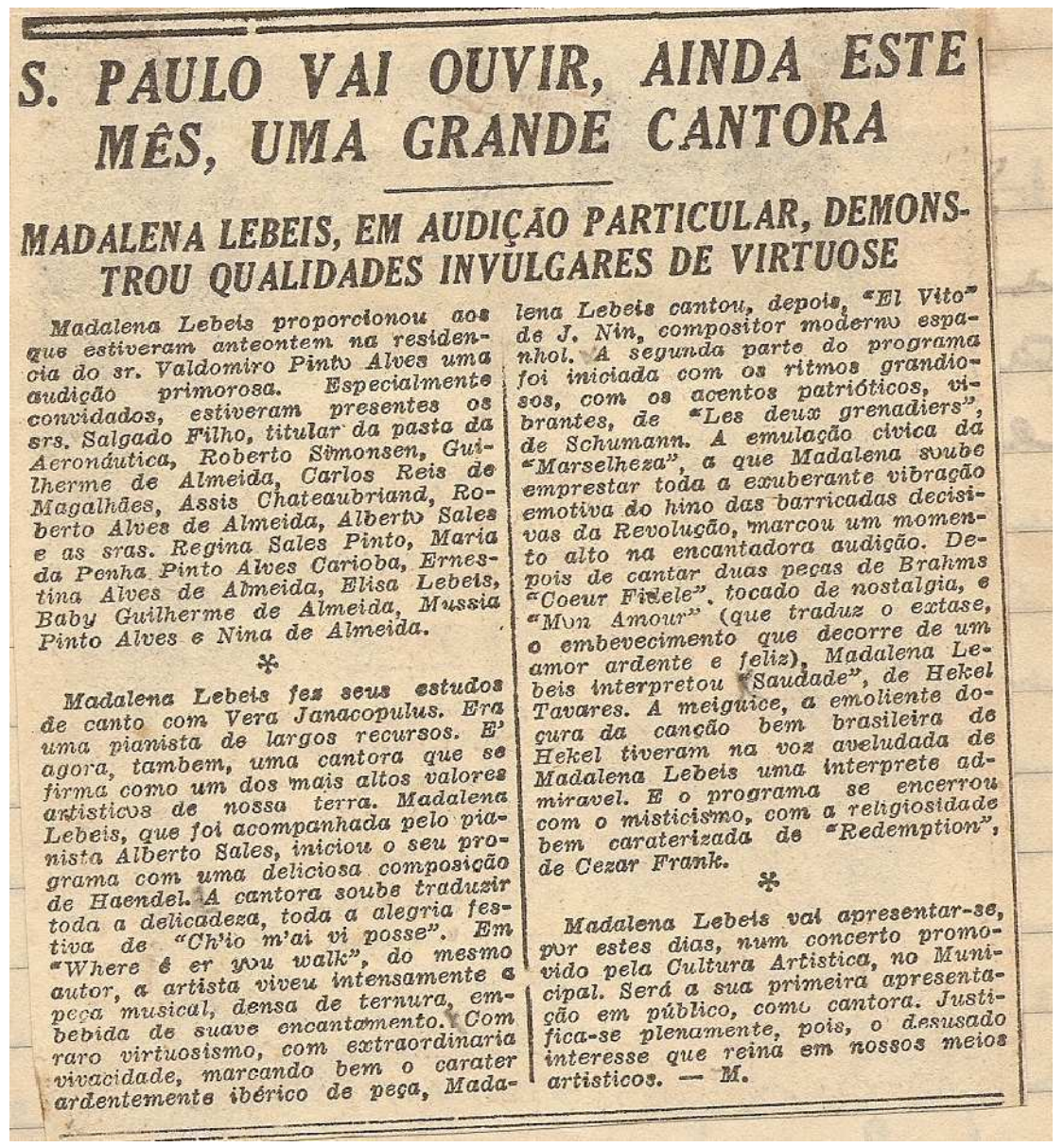

Fig. 2 - Diário de São Paulo, por Maurício Loureiro Gama, em 07/05/42.

Em 2 de junho de 1942, Lébeis se apresenta pela primeira vez para a Sociedade de Cultura Artística, transformando em realidade o convite de Esther Mesquita. $O$ programa foi regido por João de Souza Lima ${ }^{13}$, maestro com o qual ela dividiria o palco tantas outras vezes, como veremos mais adiante, no "Soirée de Gala", programa que faria parte das atrações da Rádio Gazeta, inaugurada, em 12 de março de 1943.

\footnotetext{
${ }^{13}$ Apenas consultando o programa que Lébeis anexou ao terceiro caderno, não é possível saber quem regeu o concerto, porém as aulas que o antecederam revelam o nome de Souza Lima, além de várias críticas de jornal da época, também anexadas ao mesmo caderno.
} 


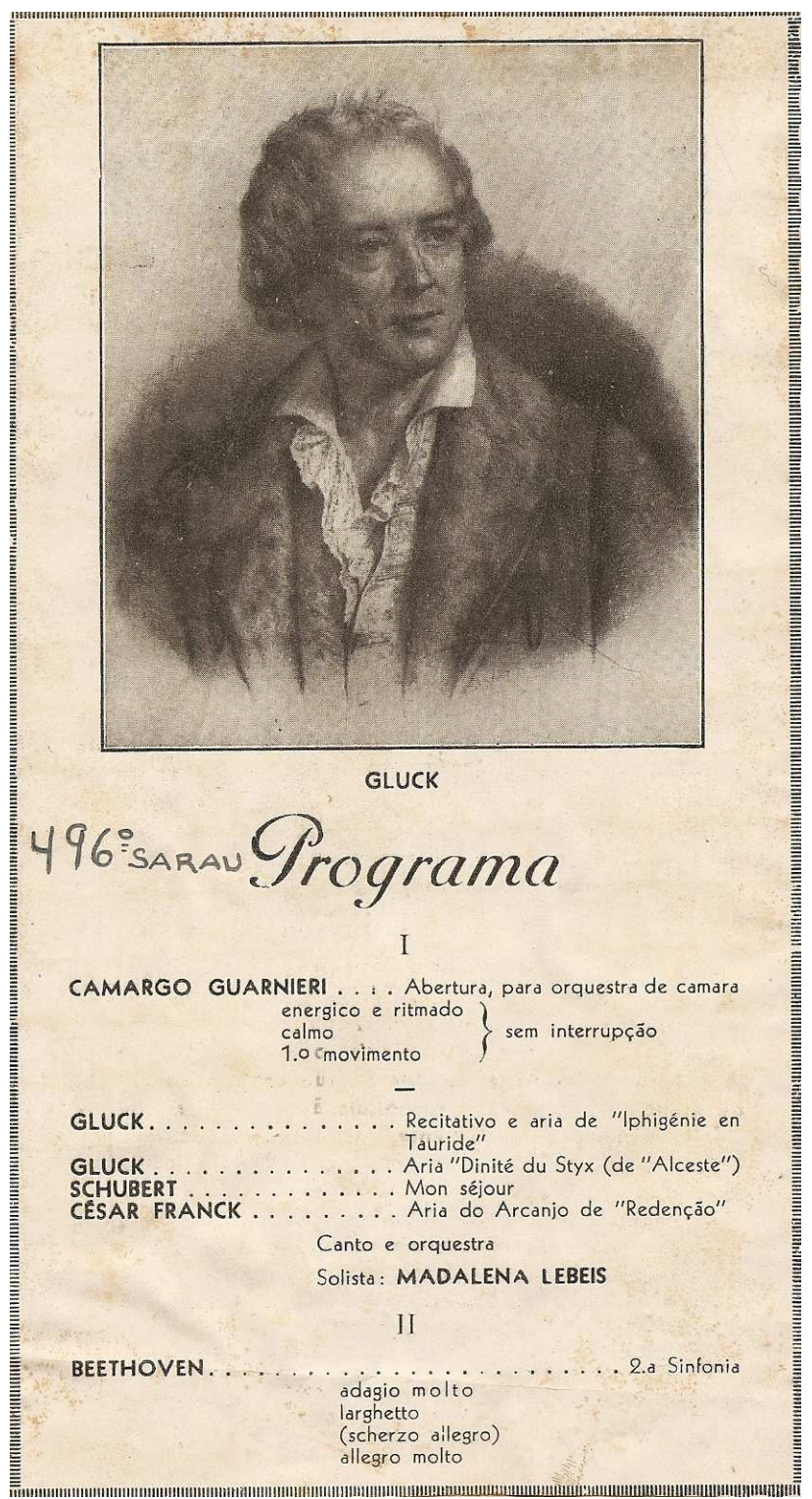

Fig. 3 - Parte do programa extraída por Lébeis, Terceiro Caderno de Aulas, p.219.

O próximo evento profissional do inicio de carreira como cantora foi um concerto para o Departamento de Cultura, regido por Camargo Guarnieri, em que Lébeis interpretou cinco peças do autor ${ }^{14}$.

\footnotetext{
${ }^{14}$ Deste concerto não conseguimos localizar o programa, porém Lébeis anexou ao terceiro caderno de aulas criticas do Diário Popular, Diário da Manhã, Folha de São Paulo e de outro jornal, não identificado, que traz detalhadamente o programa realizado naquela noite.
} 


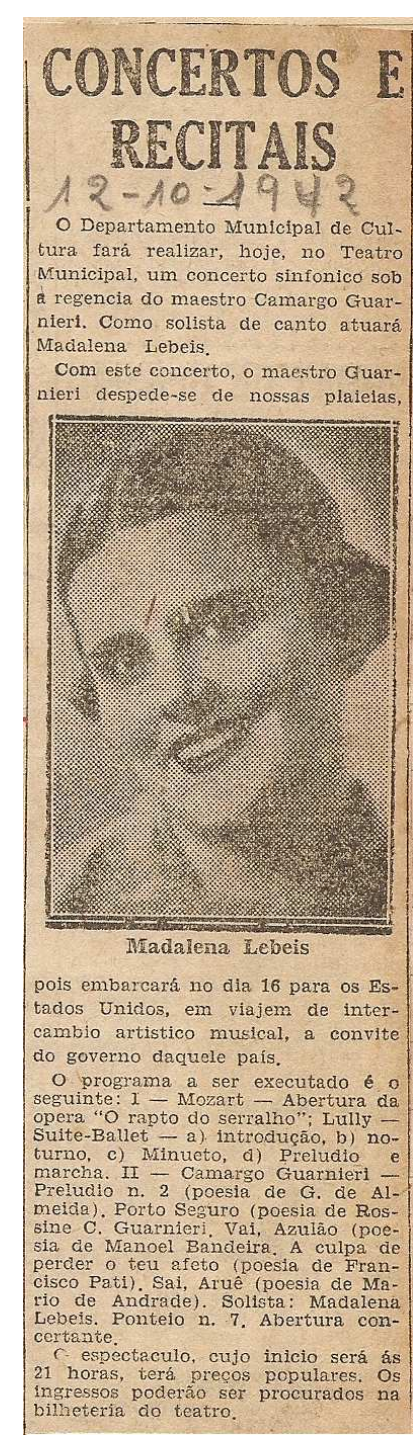

Fig. 4 - Recorte compilado por Lébeis, terceiro caderno de aulas, p. 257.

Nota-se aqui a primeira das interpretações públicas de obras de Camargo Guarnieri por Lébeis. Se observarmos atentamente o programa descrito no recorte, perceberemos que o repertório contava com textos de Manuel Bandeira e Mário de Andrade, intelectuais formadores de opiniões decisivas para os rumos estéticos da arte no Brasil. Lébeis não era uma interprete separada de seu tempo, e sim parte da voz do pensamento dos ideais modernistas. 
Nos anos seguintes, 1943, 1944 e 1945, Lébeis continuou se apresentando na programação da Sociedade de Cultura Artística ${ }^{15}$, onde realizou seu primeiro recital solo, na temporada de 1943, participou de eventos promovidos pelo Departamento de Cultura e pela Comissão Municipal de Cultura de Santos, da programação do Hotel Esplanada, além de audições particulares em casas de mecenas paulistanos, como a família Klabin. Em 1945, realizou audição, na casa de Carleton Sprague Smith para o diretor da Columbia Concerts.

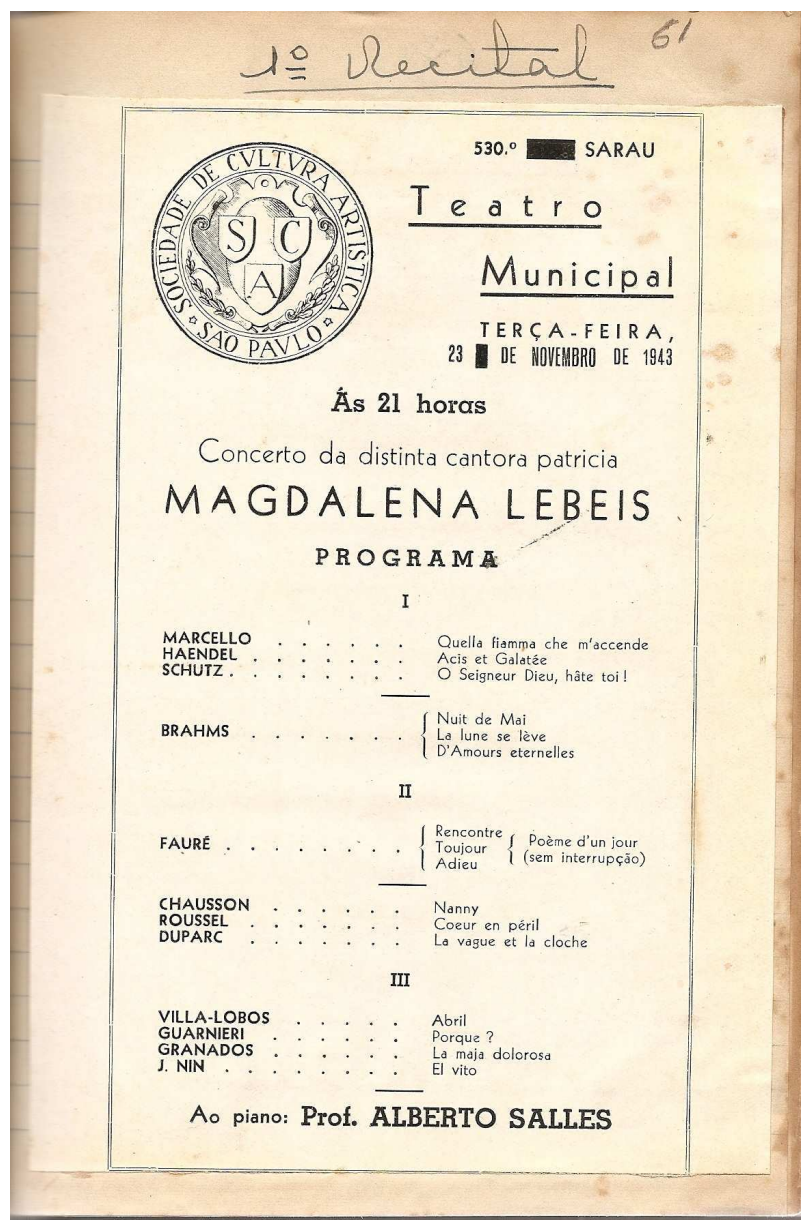

Fig. 5 - Primeiro recital solo, quarto caderno de aulas, p. 6.

\footnotetext{
${ }^{15}$ Lebramos que a programação da Sociedade de Cultura Artística não se limitava a apresentações na cidade de São Paulo, havia também programas da Sociedade pelo interior do Estado de São Paulo e também no Estado do Rio de Janeiro.
} 
Em dezembro de 1945, a cantora se apresentaria mais uma vez no Teatro Municipal de São Paulo, sob regência de Lamberto Baldi. Em 1946 ela realizou, no Rio de Janeiro, um recital para o Centro Musical Roxy King, no Salão Leopoldo Miguez, e se apresentou duas vezes na temporada da Sociedade de Cultura Artística: num recital solo, acompanhado por Fritz Jank, e na homenagem a Mário de Andrade por ocasião do primeiro aniversário de seu falecimento. O programa dedicado a Mário de Andrade merece observação mais atenta, seja pelo repertório, totalmente brasileiro e característico dos ideais estéticos do artista, além da primeira audição de "Lembrança do losango caqui" de Guarnieri, seja pela participação de Manuel Bandeira na primeira parte do programa.

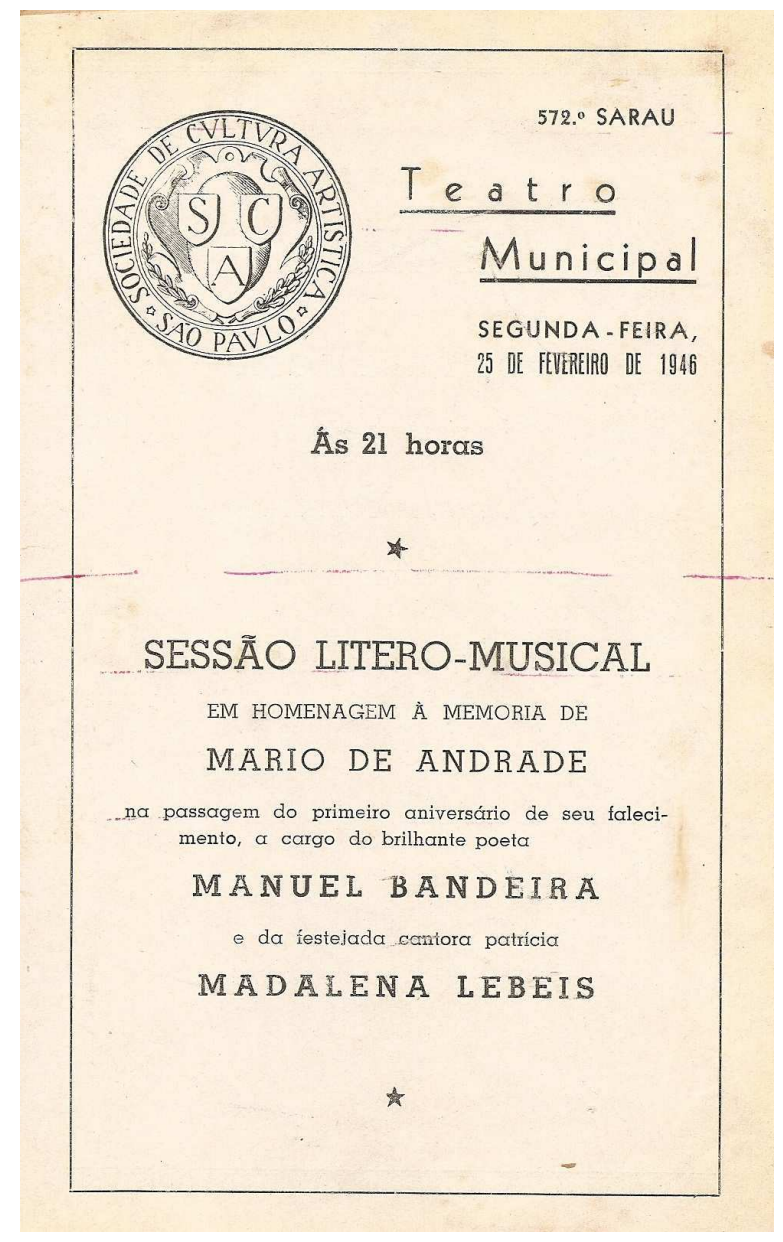

Fig. 6 - Programa compilado por Lébies, quarto caderno de aulas, p. 277 


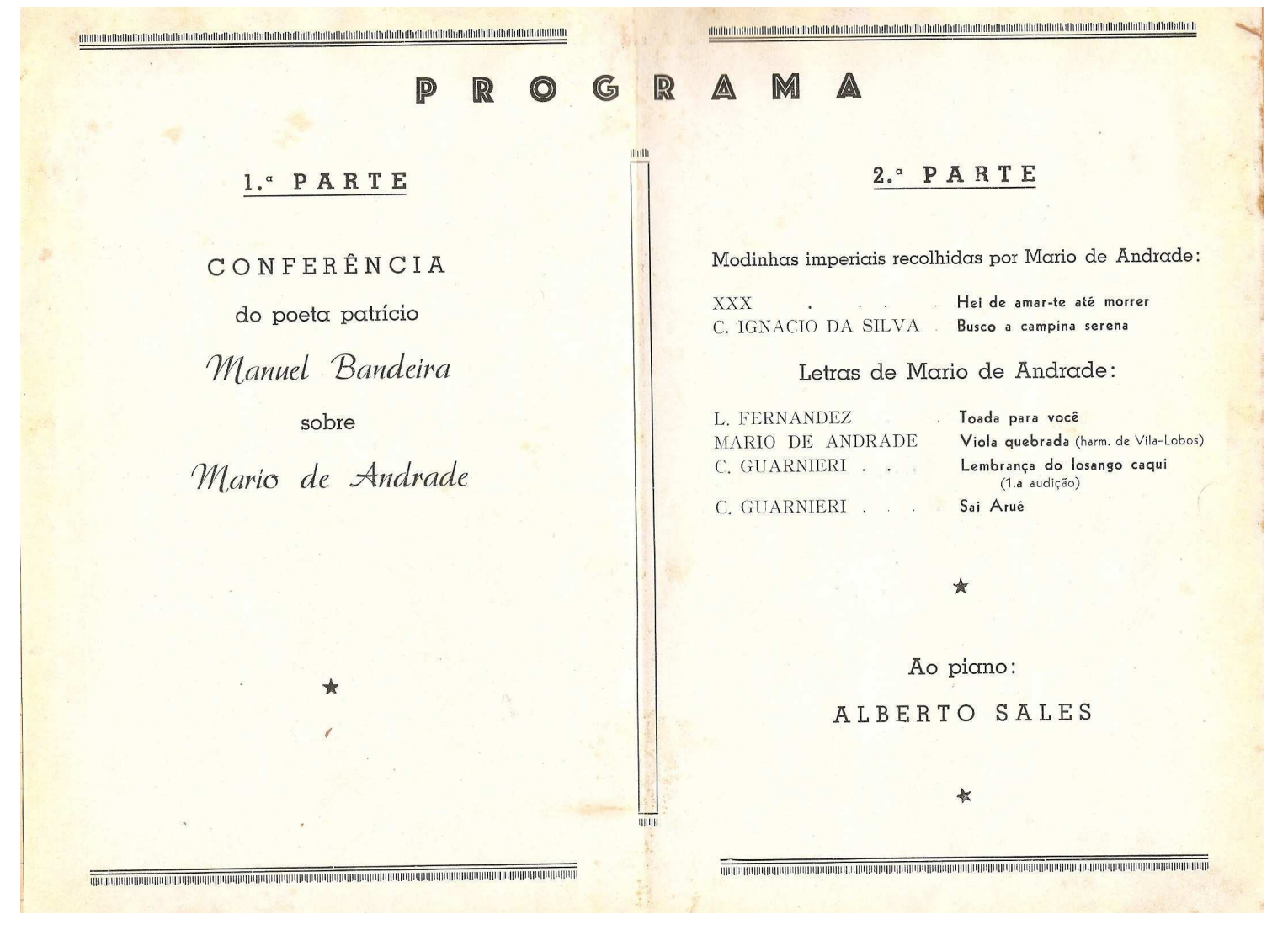

Fig. 7 - Programa compilado por Lébies, quarto caderno de aulas, p. 277

O quarto caderno de aulas termina no ano de 1947, com o registro de outro recital com Jank, para a Sociedade de Cultura Artística do Rio de Janeiro, de um concerto na Escola Nacional de Música e da participação na programação da Rádio Roquete Pinto, também no Rio de Janeiro. As apresentações em terras cariocas demonstram que Lébeis estava conquistando o seu espaço na cena da música erudita no Brasil.

Contratada pela Rádio Gazeta, onde Janacópulos dirigiu o programa "Música dos Mestres", Lébeis manteve periodicamente, durante o ano de 1948, uma rotina semanal de concertos, acompanhada ora pela orquestra da rádio, regida por Souza Lima, no programa "Soirée de Gala", ora pelos seus mais frequentes colaboradores, Fritz Jank e Alberto Salles. Provavelmente devido à exigência de uma participação semanal (as transmissões eram ao vivo e com público no auditório), Lébeis naquele ano dedicou-se 
quase que exclusivamente ao programas da Gazeta, fazendo exceção apenas para um concerto na temporada da Sociedade de Cultura Artística, acompanhada por Jank, em 17 de maio. Lembrando que as aulas com Janacópulos não foram interrompidas e observando a frequência com a qual eram ministradas, podemos supor o tempo de estudo e a energia que demandavam. Para ilustrar o período dedicado à Gazeta, escolhemos os registros de Lébeis das duas primeiras participações e, talvez, das últimas quatro, já que se tratam das últimas anotações sobre a Gazeta.

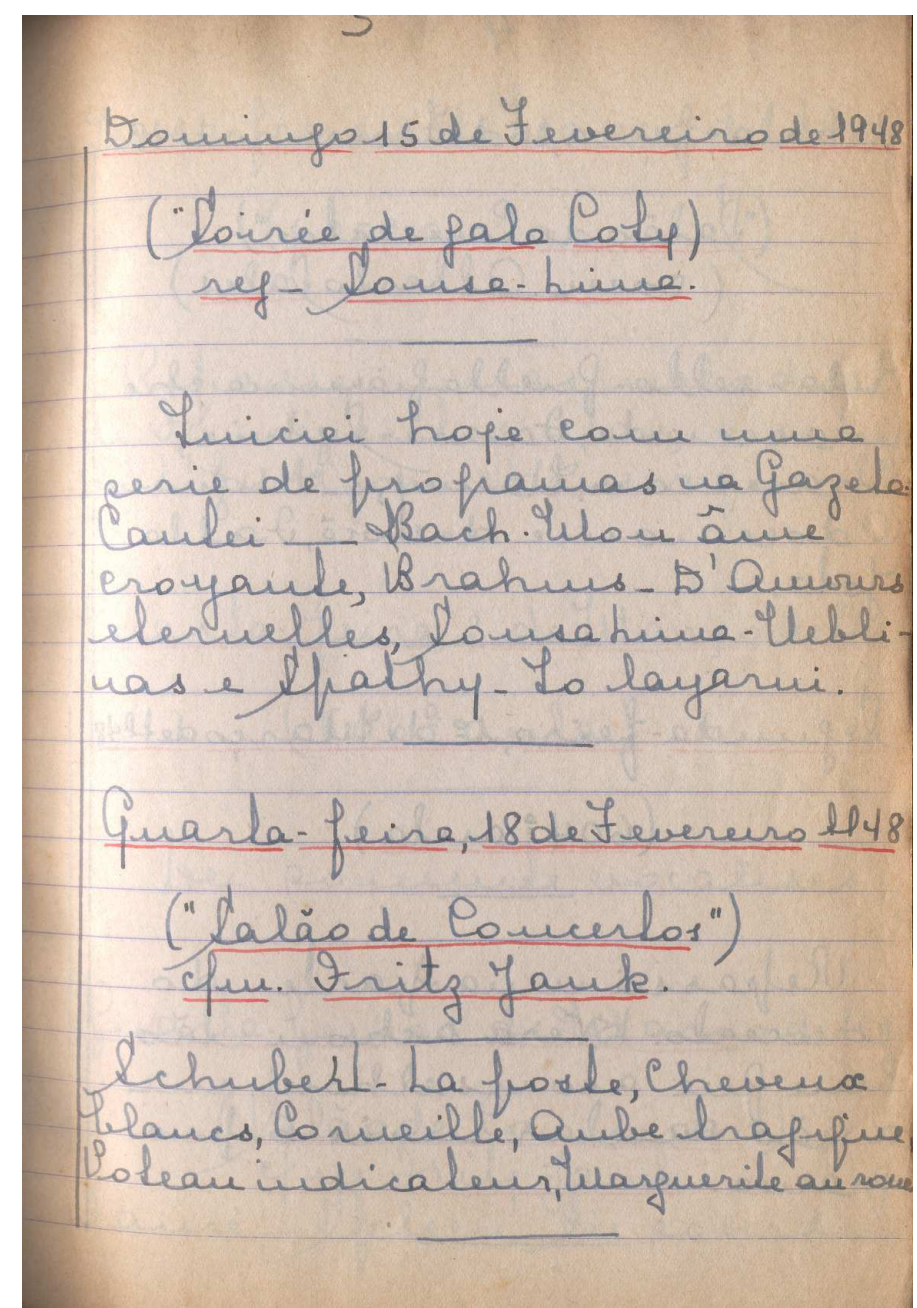

Fig. 8 - quinto caderno de aulas, p. 3 


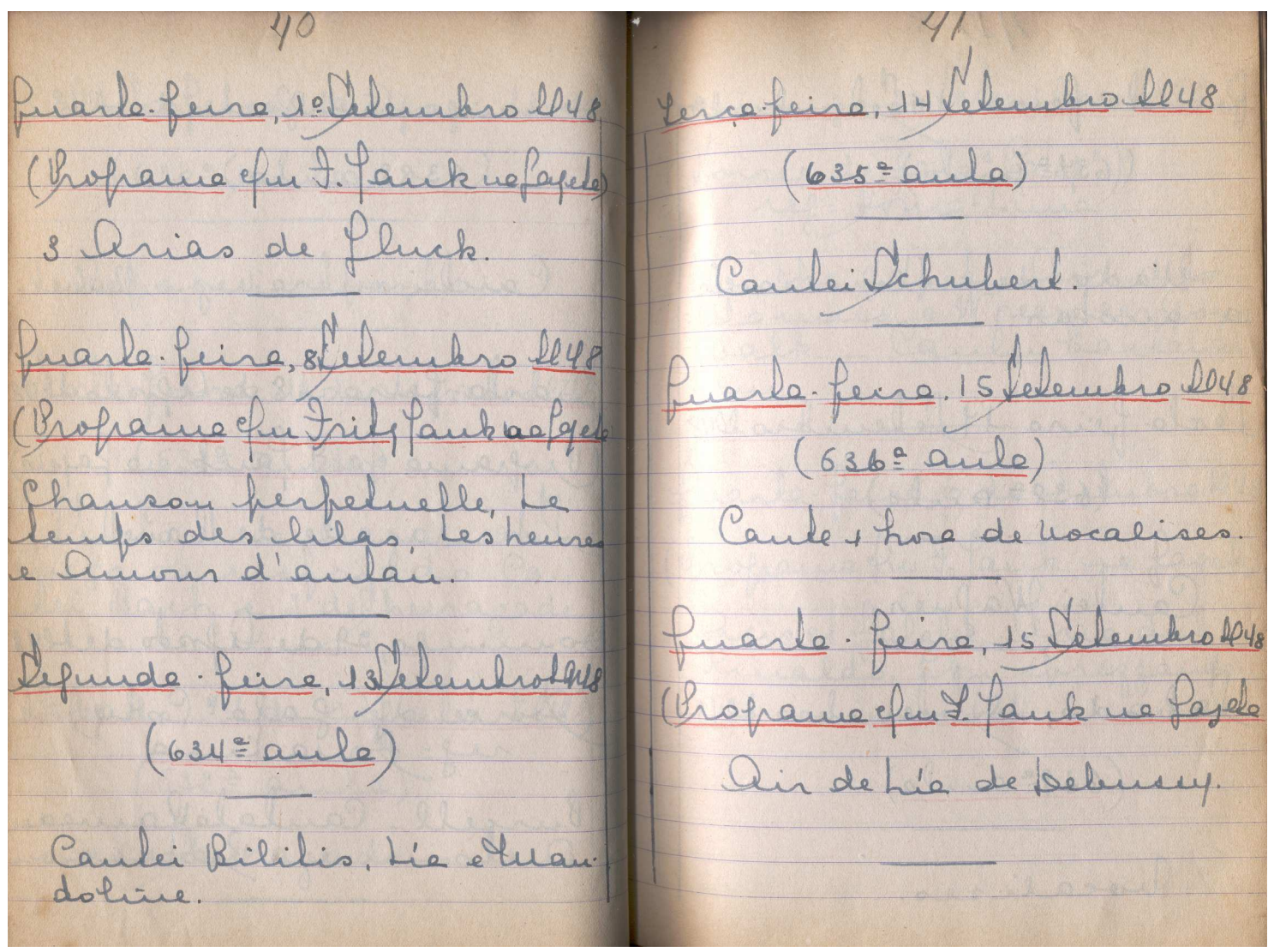

Fig. 9 - quinto caderno de aulas, p. 44 e 45.

Em 1949, Lébeis registrou vinte e cinco aulas e apenas um concerto em Santos, patrocinado pela Comissão Municipal de Cultura.

Em 1950, Lébeis faria quatro apresentações na temporada da Sociedade de Cultura Artística, e o primeiro deles representa um dos pontos mais altos de projeção e prestígio que um artista que se dedicasse à música erudita pudesse alcançar no Brasil naquela época: o de inauguração do Teatro Cultura Artística. Naquela noite, dividindo o programa com Heitor Villa-Lobos, Lébeis interpretou, regida por Camargo Guarnieri "Saudade Indefinida", com letra de Suzana de Campos, "A Serra do Rola-Moça”, com texto de Mário de Andrade, e "Antianti é Tapejara”, extraída do Macunaíma. Villa-Lobos regeu as "Bachianas no. 8" e o "Choros no. 6". Com exceção do "Choros n.6" e de "Antianti é Tapejara", todo o programa foi feito em primeira audição. Em primeira audição brasileira, ainda em 1950, Lébeis apresentaria seis peças de Francis Poulenc. 


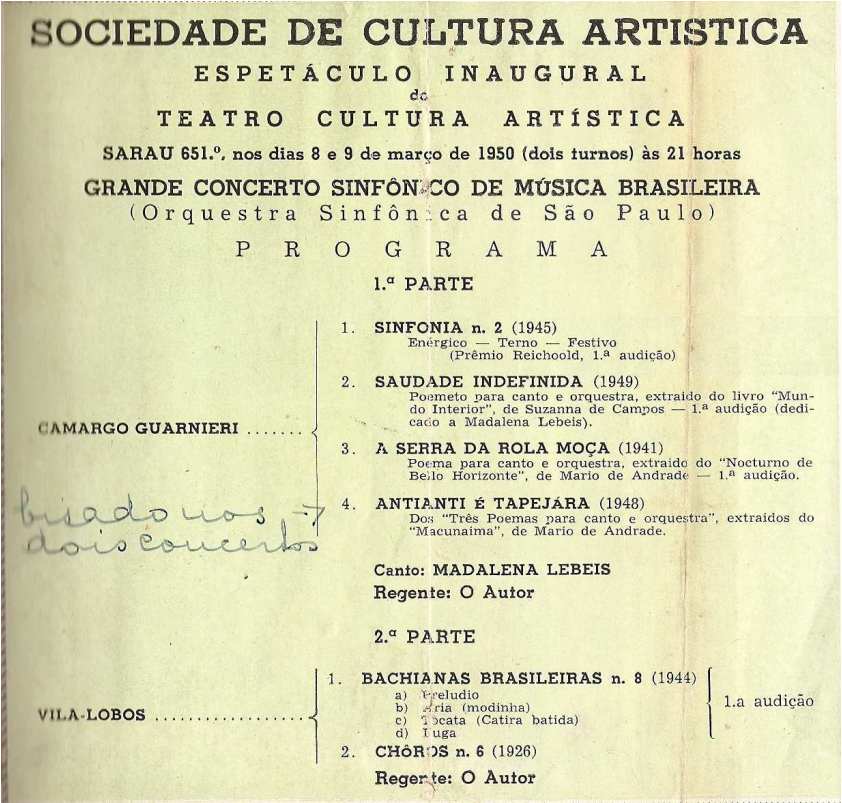

Fig. 10 - quinto caderno de aulas, p. 93.

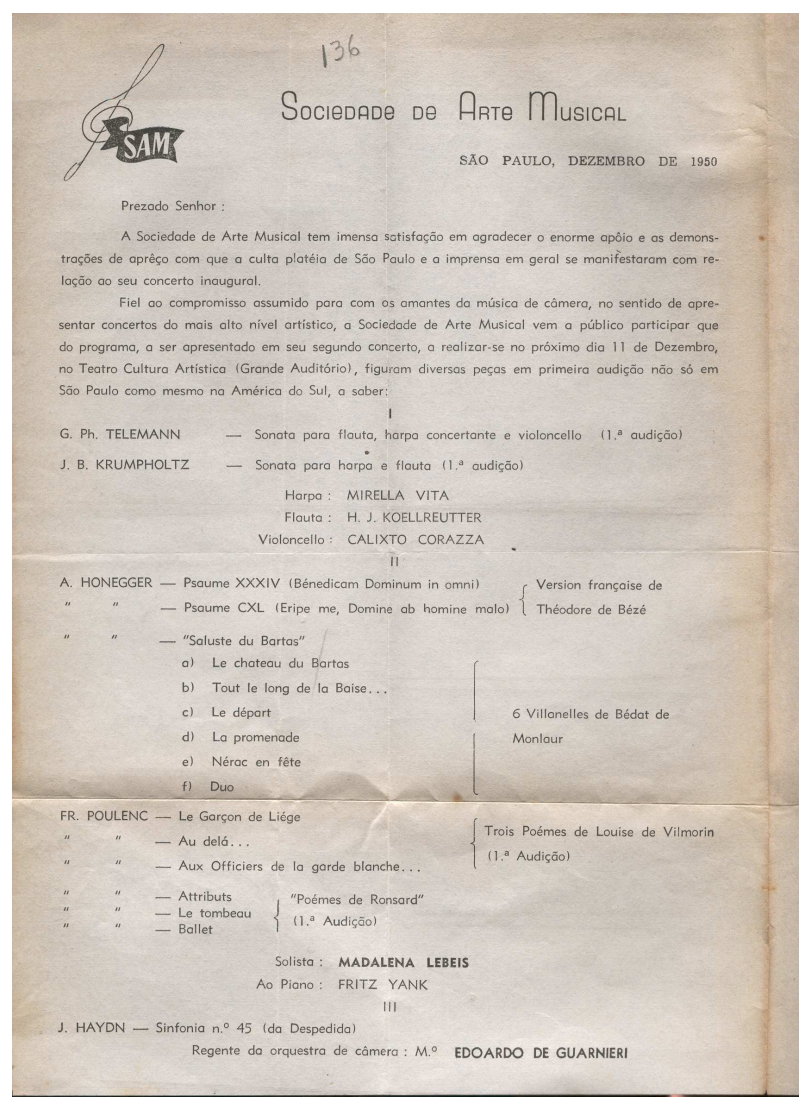

Fig. 11 - quinto caderno de aulas, p. 136. 
Menos de um ano depois do encontro com Villa-Lobos, em 1951 surgiria o convite para integrar, como membro-intérprete, a Academia Brasileira de Música (AMB).

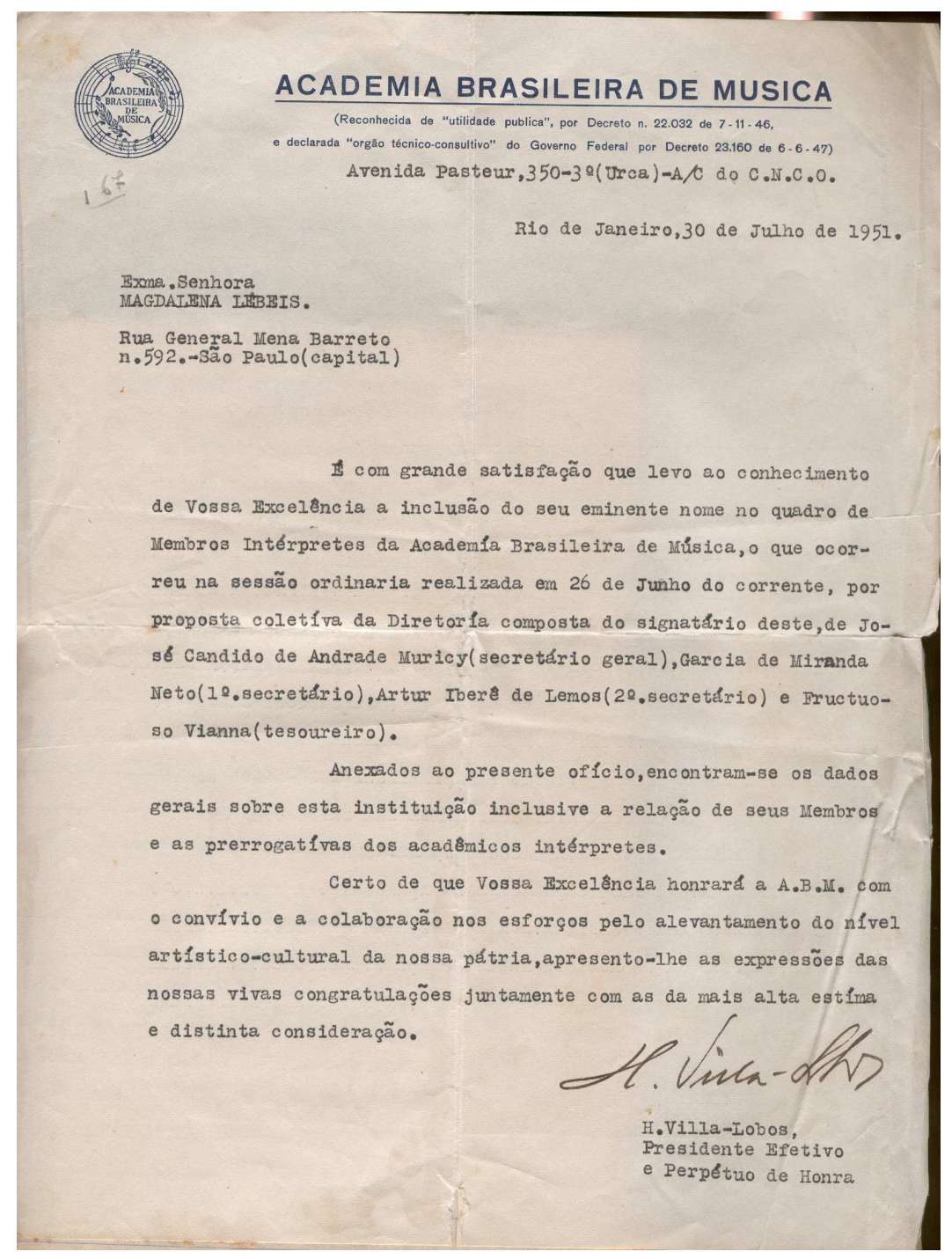

Fig. 12 - Carta original digitalizada, assinada por Villa-Lobos, Coleção Magdalena Lébeis.

Em 31 de Julho de 1951, Villa-Lobos escreve à Lébeis sobre o mesmo assunto, porém, de maneira informal:

Rio, 31 de Julho de 1951

Prezada amiga Magdalena: 
Só hoje venho responder suas amáveis cartas de 4 e 24 corrente, devido a inúmeros resfriados, tosses, etc., e, graças à ${ }^{16}$ Deus, quase liquidados.

Você não terá que agradecer-me a indicação de seu nome para a Academia, mas sim a você mesma, pela sua arte, sua voz, seu valor artístico. Como você não ignora, para mim não há bondade em arte - há sim - valor.

Não tivesse Você o valor que julgo ter ${ }^{17}$, e, por bondade, você não teria o meu apoio artístico.

Dentro de poucos dias você receberá a comunicação oficial da Academia. Já forneci à secretária o seu endereço.

Até hoje, de nada sei sobre os concertos em São Paulo. Souza Lima, há dias de passagem pelo Rio, declarou-me que vai verificar o que há de definitivo, para, então, podermos concretizar a execução de Itabira.

Agora, outro assunto: quer Você participar de uma série de concertos organizados pelo Conservatório Nacional de Canto Orfeônico, aqui no Rio? Esses concertos devem ser realizados no mês de Outubro, no Ministério de Educação.

Infelizmente a verba é pequeníssima, e caso Você concorde em colaborar com o Ministério da Educação, nesse empreendimento cultural, você terá a importância de $\mathrm{Cr} \$ 3.500,00$ (três mil e quinhentos cruzeiros) e a data seria 17 de Outubro, às 21 horas. (1 hora de programa). Como acompanhador você terá o excelente pianista Alceu Bocchino.

Esperando que Você possa enviar uma resposta urgente nesse sentido, aqui vão as nossas saudades extensivas à Família, e o cordial abraço do sempre amigo,

H. Villa-Lobos ${ }^{18}$

(Villa-Lobos, Carta, CML Doc. 1-B, 31 de Julho de 1951)

A então acadêmica Lébeis daria continuidade à carreira durante a década de 1950, mantendo as participações periódicas nas temporadas anuais da Sociedade de

\footnotetext{
${ }^{16}$ Mantivemos o texto de acordo com o datiloscrito original (CML Doc. 1-B).

${ }^{17} \mathrm{Na}$ palavra "ter" há uma rasura - primeiramente foi escrito um [v] no lugar do [t]. Há outras rasuras no quarto e no último parágrafo, porém nada que comprometa o entendimento do documento.

${ }^{18}$ Ao final da carta, acima do nome datiloscrito de Villa-Lobos, consta a assinatura autógrafa do compositor.
} 
Cultura Artística, a parceria com Fritz Jank e a realização de trabalhos com diversos maestros, tais como Edoardo de Guarnieri e Souza Lima, apresentando-se como solista da Orquestra Sinfônica Brasileira, com a Orquestra Municipal e de Câmara de São Paulo, no Cine Atlântico e no Teatro Colyseu Santista, ambos em Santos, fazendo parte da programação da Rádio Roquete Pinto e da Rádio Nacional. Em 1954, como parte de suas atribuições de membro-intérprete da ABM, ela cantaria num recital ${ }^{19}$ para recepcionar a pianista Marguerite Long.

Novamente em visita ao Brasil, em 1957, Marguerite Long fez uma conferencia sobre Claude Debussy, desta vez trazida pela Academia Paulista de Música (da qual Lébeis foi membro e uma das fundadoras ${ }^{20}$ ). Na ocasião Lébeis se apresentou acompanhada por Jank.

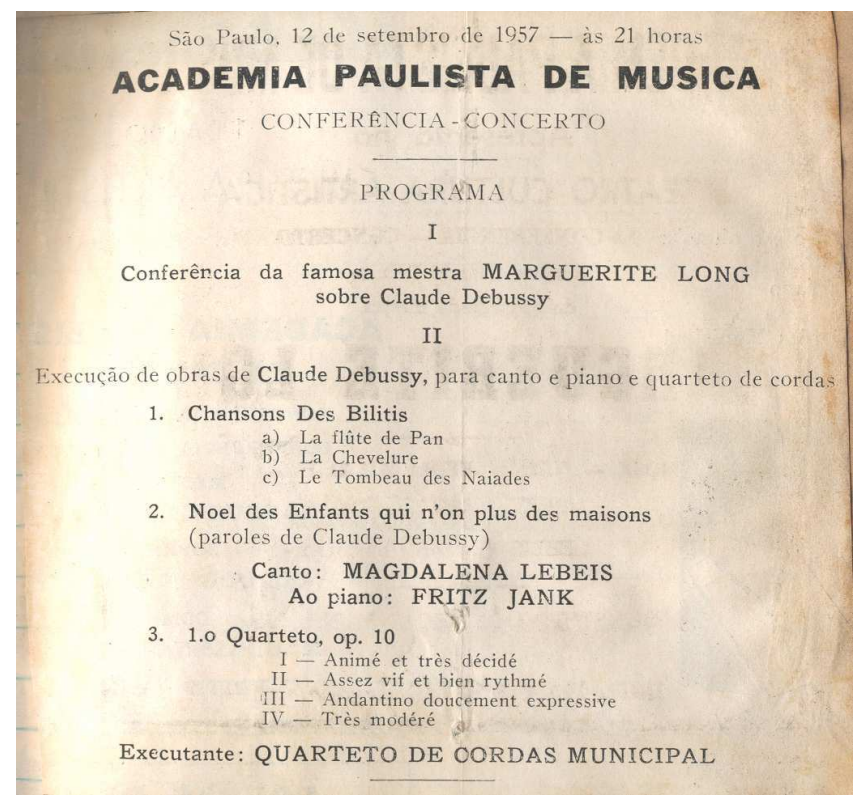

Fig. 13 - sexto caderno de aulas, p. 67

No mesmo mês, setembro de 1957, Lébeis cantaria, regida por Heitor VillaLobos, a "ópera de concerto", assim intitulada por ele, "Poema de Itabira", obra que Lébeis vinha preparando havia quase uma década e que motivou, em 1950, a

\footnotetext{
${ }^{19}$ O programa de concerto encontra-se anexado ao quarto caderno de aulas, p. 238

${ }^{20}$ Convém lembrar que, além ser uma das fundadoras da Academia Paulista de Música, Lébeis fundou o Círculo de Arte Vera Jancópulos, sendo vice-presidente da instituição.
} 
elaboração de um texto contundente sobre a postura de Fritz Jank em relação àquela obra.

Complicadíssimo é o poema de Itabira. Penso que vocalmente não há dificuldades mas...não poderei cantar na tonalidade em que está escrita porque, desde que é para contralto, a orquestra abafa minha voz.. O Jank, com sempre hostil a musica brasileira - lê com pouco interesse -- como se a literatura musical consistisse apenas em Beethoven! Não! Há muita coisa interessante que uma pessoa que é verdadeiramente artista terá curiosidade e o bom gosto de conhecer. - Villa-Lobos! O criador genial do nosso grande Brasil. [...]. Coitados daqueles que não tem alma de artista à altura de compreender a grandiosidade do gênio de Villa-Lobos! O belo Poema de Itabira! As deliciosas Bachianas! - Que grande brasileiro! (LÉBEIS, quinto caderno de aulas, 1950, p. 103-105)

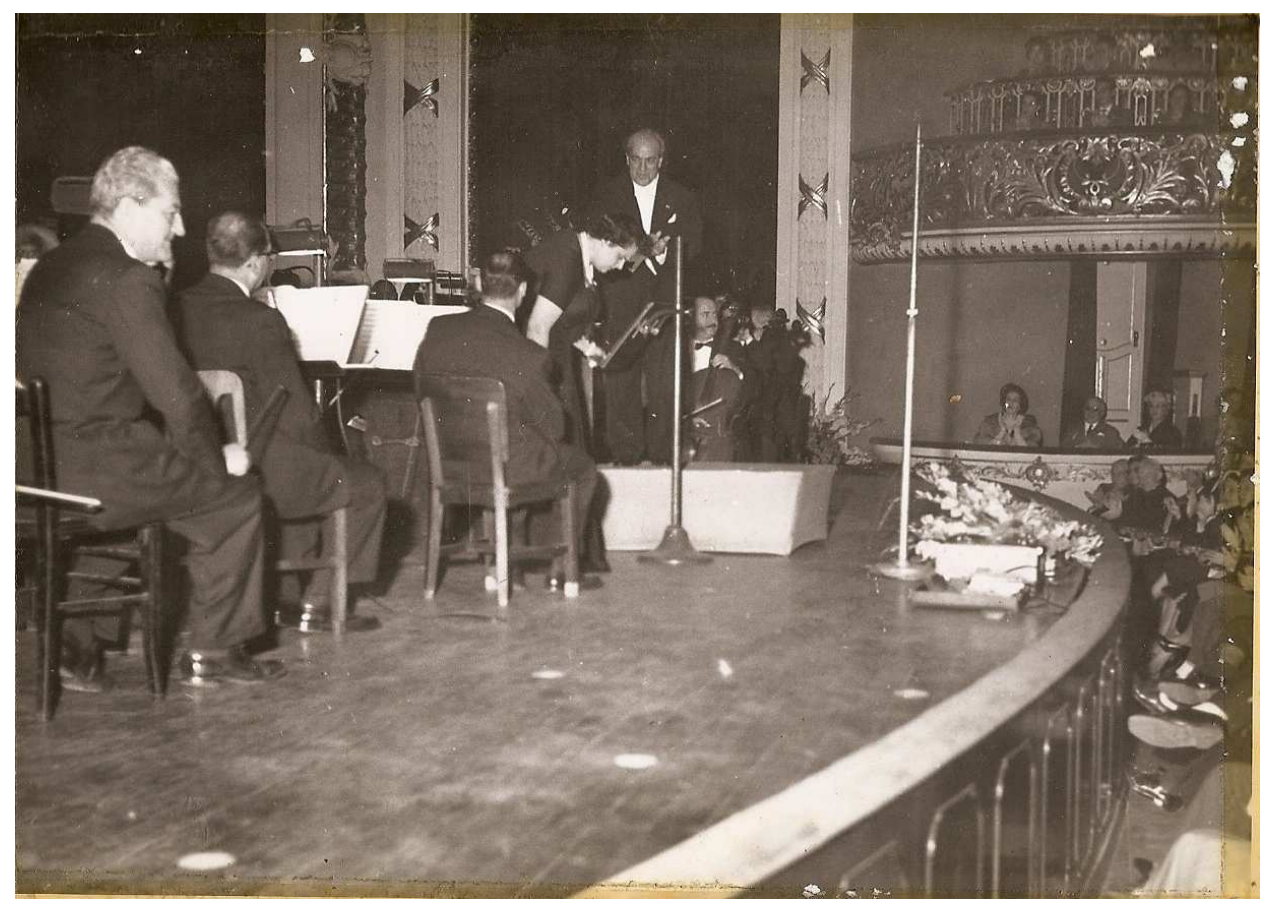

Fig. 14 - Foto original digitalizada, sexto caderno de aulas, p. 87.

O mesmo programa seria realizado no mês seguinte em Santos, sob patrocínio do Centro de Expansão Cultural. 
Antes do fim da década de 1950, Lébeis receberia uma condecoração, a Medalha Imperatriz Leopoldina, concedida pelo Instituto Nacional Geográfico, e teria, entre seus compromissos profissionais, a incumbência de cantar na inauguração da Rádio Eldorado, em São Paulo. Outra demosntração do quanto Lébeis era solicitada para se apresentar em ocasiões de projeção nacional, da mesma maneira que Janacópulos.

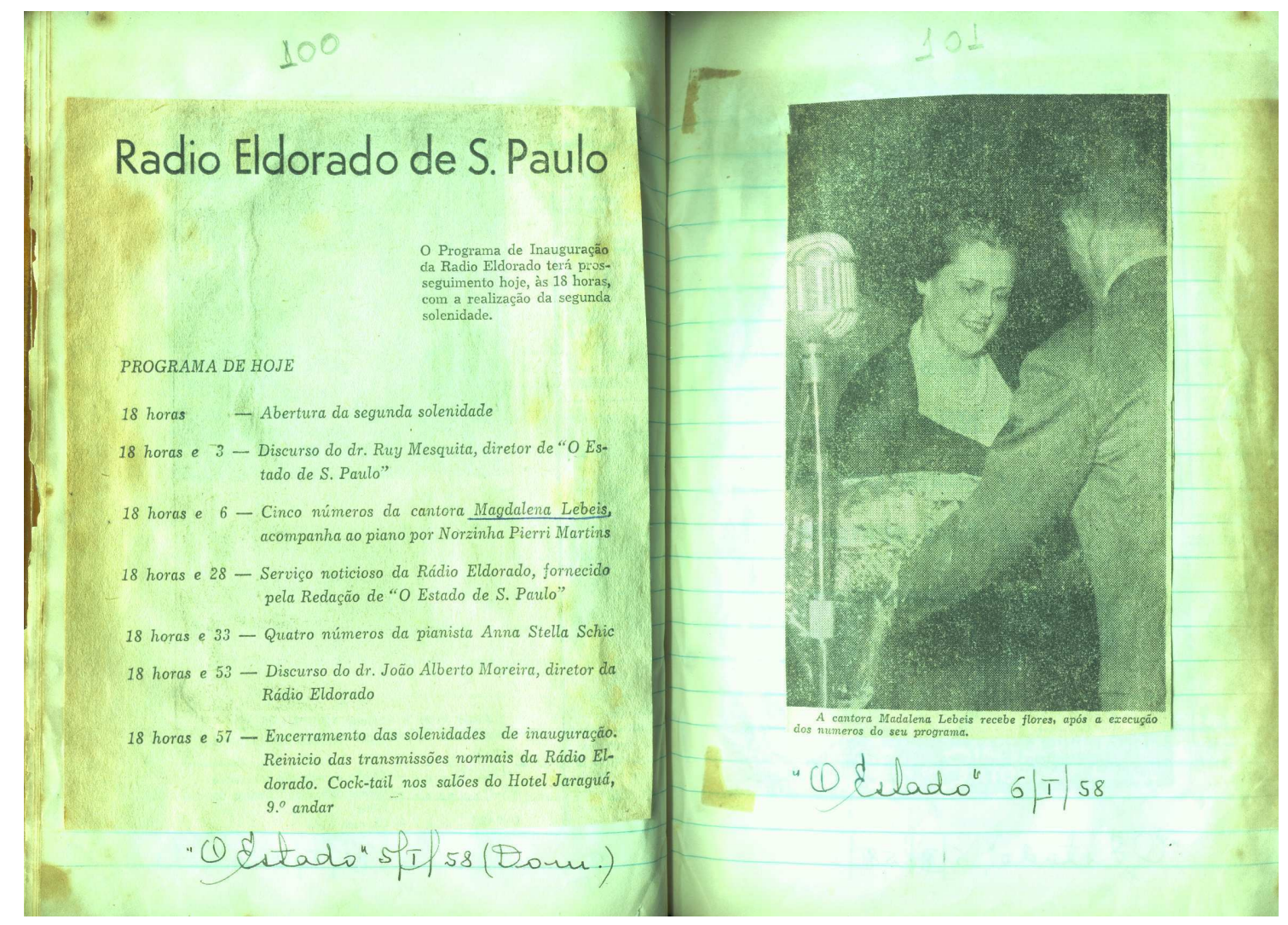

Fig. 15 - Programa de inauguração da Rádio Eldorado e recorte de do jornal O Estado, sexto caderno de aulas, p. 100-101.

A década de 1960 abrange os últimos anos da carreira de Lébeis como cantora. Fazemos a ressalva, "como cantora" porque ela lecionou até os anos 1980 em aulas particulares. O início da atividade como professora tinha se dado logo após sua primeira participação na Rádio Gazeta, como ela mesma afirma para o jornal Folha da Tarde, em 16 de fevereiro de 1981: 
Souza Lima me convidou para cantar na inauguração da Rádio Gazeta. Fiz vários recitais acompanhada por Alberto Salles e Fritz Jank. As pessoas começaram a me procurar e com elas o primeiro aluno. Desde então, é difícil enumerar quantos eu já tive. Mas menciono alguns deles: Luiza Magaldi Moraes, Zuinglio Faustini, Lenice Prioli, Carmen Zingra, Gerson Herszkowicz, Jarbas Braga, Elizabeth Lanfracoi, Leonor Barbieri, Cláudio Picolo, Marília Siegl, e vários outros que, com o correr do tempo apresentarei em público [...].

"[...] Minha vida sempre dividida entre carreira e pedagogia [...]" ${ }^{21}$. Lébeis foi professora de dicção na Escola de Arte Dramática durante oito anos, dando continuidade ao trabalho que Janacópulos vinha desenvolvendo durante dois anos devido às iniciativas de Alfredo Mesquita, além de promover cursos públicos de interpretação do repertório vocal de câmara, em São Paulo, no Rio de Janeiro e em Recife. Na década 1960 recebeu o premio de melhor cantora da Associação Paulista de Críticos Teatrais, justamente no primeiro ano em que se premiou a categoria "Música" (sendo laureada novamente com o mesmo prêmio em 1962), se apresentou na TV Cultura, lançou um long play acompanhada por Fritz Jank, realizou recitais com piano e concertos com orquestra, um dos últimos chama especial atenção já com o título: Recital sem Programa.

Mas por quê "Recital sem Programa?" - Por que? - Nem exotismo, nem inovação, nem propriamente idéia...e sim procurar a concretização de um velho sonho, - tão sonhado por todos - um sonho que muitos tem e que, por protocolo ou falta de coragem de concretizá-lo, nunca tomaram tal iniciativa! Esse sonho é simples: consiste apenas em quebrar essa barreira que sempre existiu entre o artista e o público, entre o público e o artista. Através dessa barreira, torna-se difícil sentir o ritmo e o pulsar dos corações que se encontram na platéia, e nada melhor para o artista, que esse intercambio afetivo; dar-lhe-á o ensejo de cantar ou tocar seguindo aos mandados da alma, sentindo, bem mais de perto, o eco e a reciprocidade todas as outras almas que vieram ao teatro para ouvi-lo.

\footnotetext{
${ }^{21}$ Palavras de Lébeis no discurso de abertura das aulas públicas realizadas no Rio de Janeiro em 1972, (CML Doc. 21/Fichário).
} 
"Recital sem Programa", para ser esclarecido é fazer música, cantar para os amigos, sem protocolos, sem obedecer a seqüência da épocas, cantar o que tiver vontade, cantar de coração para vários corações; de Haendel, passar a um espanhol, de uma Modinha autenticamente brasileira, passar à uma página de Bach, de um "lied" de Schumann ao contraste estilístico de uma Ária de ópera. Cantar! Pelo sublime prazer de cantar! Fazer do canto uma Oração, um agradecimento, um enlevo, um momento de sonho, de beleza e de poesia - ou uma terna confidência...Eis o que é um "Recital sem Programa (LÉBEIS, 1961, sexto caderno de aulas, p. 208)

Segundo o texto transcrito acima, Lébeis não entende como inovação a proposta do recital sem programa, porém nos parece hoje inovadora, principalmente por romper com a barreira entre o artista e o publico e por promover uma escuta diferenciada. Ainda que Lébeis não classificasse a proposta como "inovadora", naquela ocasião ela acreditava ser uma iniciativa inédita, fato que posteriormente ela própria reconsiderou em artigo escrito a respeito de Janacópulos, Poulenc, Milhaud e Ravel:

Houve certa vez em Paris um concerto, todo de primeiras audições, mas "Recital sem programa". Aqui faço um parêntesis relembrando o que lancei no Brasil, expontaneamente (sic). Os grandes críticos de música, como Caldeira Filho, Alberto Ricardi, Rangel Bandeira, Orlando Nasi, Dinorá de Carvalho, Andrade Muricy, Nogueira França, Ondina Dantas, Ayres de Andrade, Massarani, aos quais pedi conselho, se poderia realizar essa coisa inédita, a resposta foi uma só: você pode. [...] (Artigo datiloscrtio, não publicado, s.d, 6 p. Doc. 23/3 - CML)

Lébeis, durante todo o seu percurso artístico, valorizou especialmente a música brasileira, fato que facilmente se comprova diante do grande número de aulas feitas com Janacópulos dedicadas ao repertório nacional, pela numerosa e especialmente valiosa coleção de partituras da artista (com edições raras, além de peças copiadas a mão da coleção Vera Janacópulos ${ }^{22}$ ), pelas dezenas de peças anotadas por Lébeis,

\footnotetext{
${ }^{22}$ No rascunho datiloscrito de uma critica musical, preparada para ser publicada no jornal $A$ Gazeta, Lébeis revela que a coleção de partituras de Vera Janacópulos, extremamente importante para a compreensão do desenvolvimento do modernismo musical no Brasil, como nos esclarece os recentes
} 
pelas obras brasileiras autografadas por seus respectivos compositores ${ }^{23}$, pelas obras dedicadas a Lébeis por nomes da estatura de Souza Lima, Camargo Guarnieri, José Viera Brandão, Lina Pires de Campos, César Guerra-Peixe, Osvaldo Lacerda e Francisco Mignone, pelos numerosos programas de concerto feitos por ela, cujo conteúdo demonstra a periodicidade de apresentações públicas do referido repertório, primeiras audições de obras de Camargo Guarnieri e de Villa-Lobos e pelos registros das aulas públicas ministradas por Lébeis, que também documentam a enfática valorização da canção de câmara brasileira, revelando compositores e obras. As apresentações de repertório brasileiro, o trabalho pedagógico embasado no que havia de mais atual em relação aos conhecimentos do funcionamento do aparelho vocal, a produção de seis Cadernos de Aulas de Canto, manuscritos, com o registro das mil e seis aulas feitas com Janacópulos, e a confecção de um volume de 51 páginas de considerações sobre o estudo do canto, escrito à mão e repleto de desenhos detalhados da anatomia do aparelho vocal, bem como considerações sobre o seu funcionamento, além do compromisso com a divulgação do repertório vocal camerístico internacional do século XX, ou seja, o da música contemporânea da época, sem, contudo, negligenciar os períodos histórico-musicais anteriores, na esteira do que fazia Janacópulos, na atuação de cantora ou de pedagoga, nos parecem ser as maiores contribuições de Lébeis ao cenário musical paulista.

\footnotetext{
trabalhos de Lago (1999; 2010), esteve sob seus cuidados na década de 1940, fato que facilitou a cópia de alguns dos itens: "Na ocasião da década de 1940 guardei em mina casa - desde que Janacópulos mudou-se para o Rio, - todas as músicas pertencentes à minha Mestra. Naquela ocasião tirei muitas cópias de melodias inteiramente inéditas que não poderia obter caso não fosse Janacópulos confiar e haver, na época o copista Lorenço Cella que a mão nos dava páginas mais claras que as próprias músicas impressas. Assim obtive as obras de Milhaud [...]"(Lébeis, CML-Doc. 23/3, 6 pg. datiloscritas)

${ }^{23}$ Dentre os quais estão Heitor Villa-Lobos, Camargo Guarnieri, João de Souza Lima, Dinorá de Carvalho, Norzinha P. Ferreira Martins, Francisco Mignone, Carlos del Negri, Teodoro Nogueira, Octavio Pinto, Arnaldo Rebelo, Osvaldo Lacerda, José Viera Brandão, Oswaldo de Souza e Cláudio Santoro.
} 


\section{CAPÍTULO 2: Elementos Técnicos}

Nas mil e seis aulas de canto, descritas por Lébeis foram abordadas as mais diversas questões técnicas, tais como o apoio, a maneira de respirar, a posição da boca, a articulação dos fonemas, a posição da língua, o ataque do som, além de vastíssimo material relacionado à interpretação, contido nos cadernos de aulas de canto.

O registro de Lébeis oferece inúmeras possibilidades de abordagem; mesmo considerando uma abordagem específica como a de elementos técnicos, há materiais suficientes para que vários pesquisadores se dediquem à pesquisa, como abordagens que possibilitem o surgimento de outros trabalhos de pesquisa derivados de seus registros sistemáticos. Diante dessa constatação optamos por delimitar a apreciação de alguns elementos técnicos descritos no primeiro caderno de aulas de canto: respiração e apoio.

Dado o volume das informações detalhadas por Lébeis em seus seis cadernos de aulas de canto, a quantidade de exemplos que poderiam ser relacionados com os elementos técnicos seria ainda em número demasiado para os limites deste trabalho. Procuramos, portanto, extrair apenas exemplos dos anos de 1937, 1938 e 1939, ou seja, exemplos que constem dos três primeiros anos de estudo de Lébeis com Janacópulos. Nesse período são compreendidas as primeiras 124 aulas, que constituem o embasamento de todo o processo técnico percorrido por Lébeis.

Acreditamos ser relevante esta triagem, porque os exercícios técnicos contemplam principalmente o período inicial do processo pedagógico o qual Lébeis percorreu, pelo menos no que poderia ser classificado como um resumo sistematizado dos principais conceitos e procedimentos relacionados à técnica vocal. Ao longo do relato de Lébeis, não apenas no primeiro caderno, mas nos outros cinco posteriores, as correções e ponderações sobre as questões técnicas permanecem em pauta, porém vão cada vez mais se transformando em ferramentas para alcançar o artístico e perdendo a função inicial de embasamento técnico das primeiras aulas.

Durante todos os anos em que Lébeis realizou o registro dos cadernos de aulas de canto, existe a preocupação com a técnica de emissão vocal; no entanto, é no início do percurso artístico (e literário, se for considerada a produção dos cadernos de aulas 
de canto também como produção literária) que os pontos fundamentais que guiarão o estudo técnico de canto de Lébeis encontram-se mais sistematizados, circunstancia esta que reflete não só o conteúdo abordado, mas também a organização pedagógica que prioriza inicialmente o domínio técnico da voz.

Usaremos como referencia teórica para as análises referentes aos elementos técnicos, respiração e apoio, o trabalho de Miller (1990; 1996), tendo como objetivo observar a linguagem usada descrita por Lébeis e usada para comunicar os elementos da técnica.

\subsection{Aspectos didáticos}

$\mathrm{Na}$ história da pedagogia vocal, a transmissão do conhecimento passou por fases distintas nas quais se podem observar sobretudo mudanças na linguagem usada para comunicar o conteúdo técnico. White (1989), no segundo capítulo, intitulado An historical review of the scienctific study of the voice and the teaching of singing ${ }^{24}$, cita o autor C. D. Taylor a respeito dessas mudanças. Taylor, já no principio do século XX, expõe sistematicamente a situação e define uma divisão do desenvolvimento da pedagogia vocal em fases: uma primeira fase que duraria aproximadamente de 16001741, cuja abordagem técnica seria empírica, uma segunda fase de 1741 a 1854 que o autor classifica como transitória e motivada pelos estudos de Ferrein; por fim, uma terceira fase que ocorreria a partir de 1855 e seria marcada pela invenção do laringoscópio por Garcia, o que imprimiu uma nova tendência, que consiste em procurar explicações para os eventos técnicos fundamentadas na realidade física.

Entretanto, no século XIX, o cenário vocal muda completamente, os últimos castrati dão adeus a cena lírica e já não são mais os principais professores, nem os responsáveis pelas inovações técnicas que marcaram o começo deste século. Começa a se desenvolver uma didática vocal baseada em princípios da fisiologia vocal. (PACHECO, 2006, p.47)

\footnotetext{
${ }^{24}$ Uma revisão histórica do estudo científico da voz e do ensino de canto.
} 
A terceira fase da pedagogia vocal permanece como tendência pedagógica atual e cada vez mais embasada em novos conhecimentos de campos interdisciplinares. A respeito disso, Miller (1996, pg. 5, tradução do autor) ${ }^{25}$ faz a seguinte consideração: "Há uma percepção crescente de que a voz como instrumento pode ser melhor trabalhada por meio de uma comunicação exata de fontes multidisciplinares."

No fichário catalogado na Coleção Magdalena Lébeis, sob o número $15^{26}$, que provavelmente era compreendido por Lébeis como o sétimo caderno de aulas ${ }^{27}$, se pode notar a preocupação da artista em compreender e transmitir conhecimentos embasados em informações objetivas quanto à anatomia do aparelho vocal, bem como sobre o seu funcionamento. Vejamos algumas destas considerações:

O instrumento vocal. Descrição - Funcionamento.

É indispensável para o cantor conhecer bem seu instrumento de trabalho? Um pianista, um violinista não podem acaso ser grandes artistas sem estar ao par dos detalhes da fabricação de seus respectivos instrumentos? [...] Como todas as partes do corpo humano, o aparato vocal é muito complicado. Nele estão números incalculáveis de nervos, vasos sanguineos, músculos, cartílagos, etc que, por terem todos nomes científicos de ressonâncias exóticas, tornam-se impossíveis de guardar cada nome. Tratarei de simplificar o possível sua descrição afim de não desalentar a ninguém e ser compreendida por todos.

1. O aparato respiratório, onde se armazena e circula o ar;

2. O aparato da fonação - que é onde o ar se transforma em som ao passar entre as cordas vocaes [sic].

3. O aparato ressonador [sic], onde o ar, transformando-se em som, expande-se adquirindo sua qualidade e amplitude. (LÉBEIS, s.d. 19-21)

\footnotetext{
25 "There is an increasing realization that the voice as instrument can best be trained through exact communicative from interdisciplinary sources."

${ }^{26}$ CML Doc. 15 - FICHÁRIO - Folhas numeradas até página 62. Nas páginas 53, 54, 55, 58, 59 e 59-A há anotações que não se relacionam com o conteúdo geral do documento; trata-se de esboço de carta de cunho íntimo que achamos por bem serem mantidas afastadas de apreciação por não contribuírem para o desenvolvimento da pesquisa. A página 56 está vazia; nas páginas 57 e 58 há um esboço de discurso a ser feito em curso de interpretação do canto de câmara a se realizar no auditório Villa-Lobos. Não há datas neste fichário.

27 "Durante dezessete anos estudei como Vera Janacópulos e, com toda a riqueza que ela me transmitiu, inspirou-me a escrever sete volumes sobre a Arte do Canto que serão publicados após meu desaparecimento" (Lébies, artigo, sem data).
} 
Ainda que possam ser discutíveis e contestadas algumas considerações de Lébeis, na citação acima, por exemplo, a afirmação de serem "números incalculáveis de nervos [...]", ou ainda "impossível de guardar", é inegável a preocupação em ser precisa quanto à anatomia do aparato vocal e ao seu respectivo funcionamento, preocupação esta presente tanto nas considerações de Lébeis como nas de Janacópulos, como poderemos confirmar nas próximas páginas. "Um melhor aproveitamento do tempo ocorre quando a linguagem técnica é trazida para a realidade física." ${ }^{28}$ (MILLER, 1996, pg. 8, tradução do autor). Veremos a seguir algumas ilustrações e textos de Lébeis a respeito do exposto:

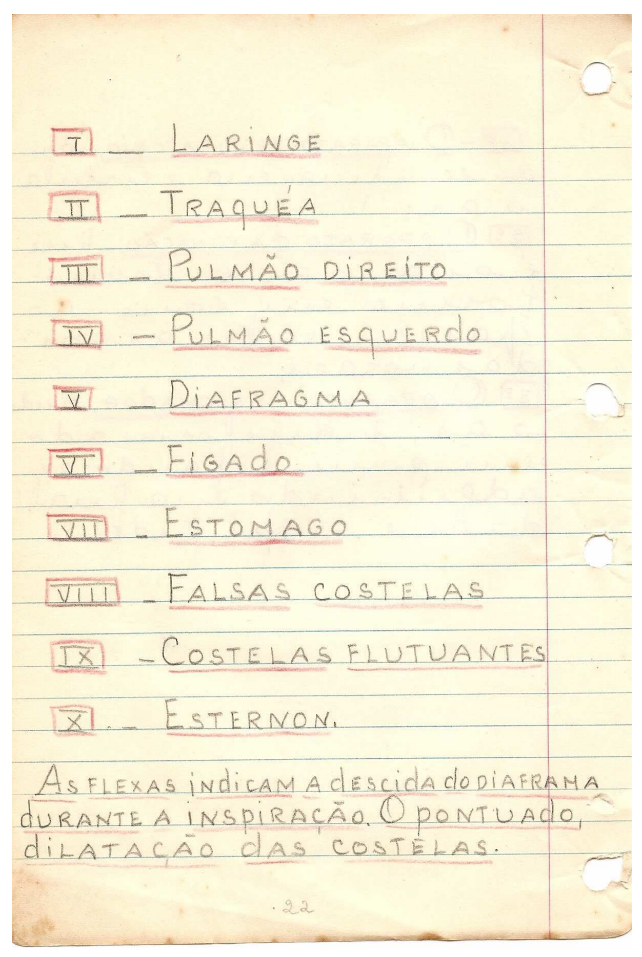

Fig. 16 CML-15, p. 22

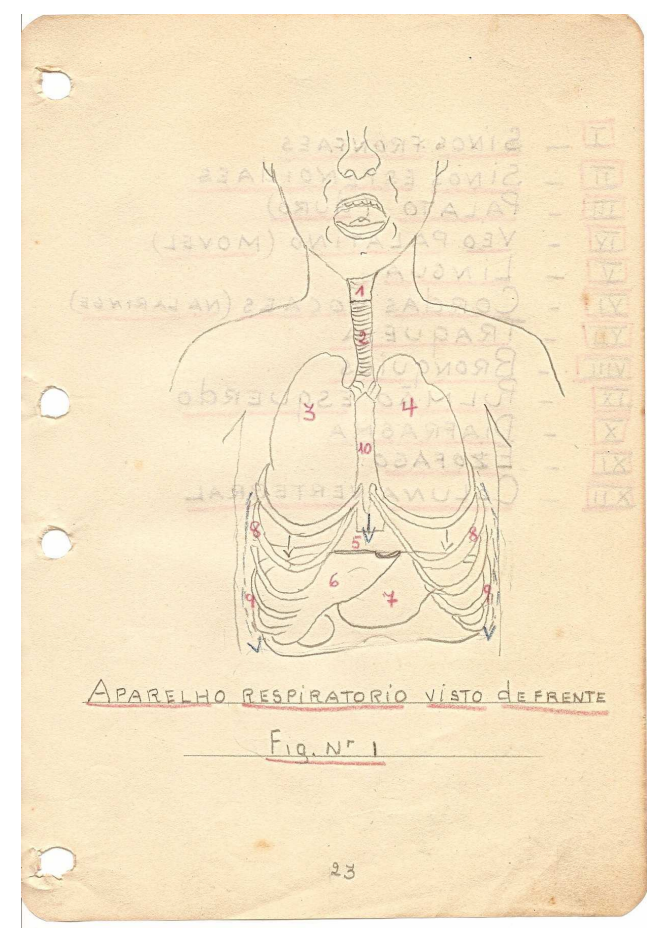

Fig. 17 CML-15, p. 23

\footnotetext{
28 "Far better husbanding of time occurs when technical language is brought into the world of physical reality.
} 


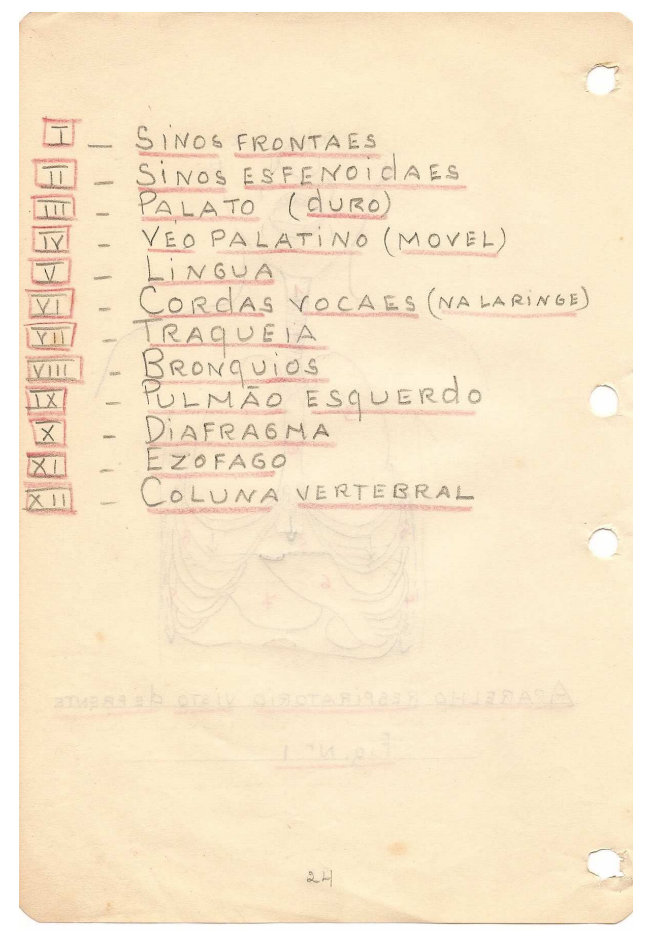

Fig.18 CML-15, p. 24)

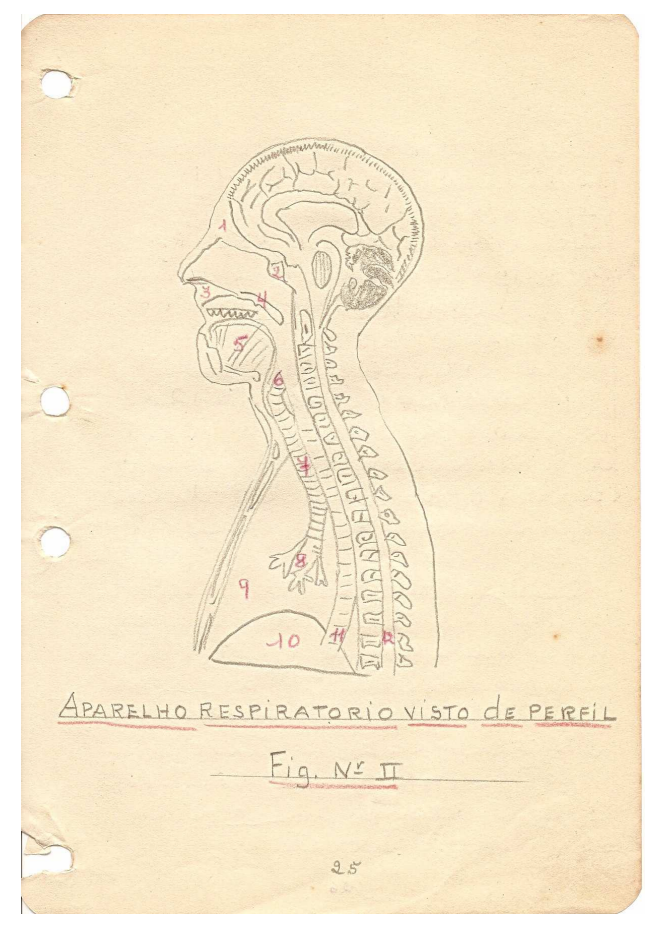

Fig. 19 CML-15, p. 25

\section{O APARELHO RESPIRATÓRIO}

O aparelho respiratório é composto do NARIZ, TRAQUÉIA, PULMÕES E DIAFRAGMA. (VER FIGS. $1 \mathrm{E} \mathrm{2}$ ) $\mathrm{O}$ ar que penetra pelo nariz (ou pela boca), passa pela traquéia, espécie de tubo largo que se divide em dois à entrada dos pulmões. Os pulmões, massas esponjosas e extensas são nossos receptáculos de ar. Estão contidos na caixa torácica. (ver figs. 3 e 4) Essa caixa óssea é formada de cada lado por 12 costelas (ossos curvos e chatos) fixados por de traz da coluna vertebral. Dessas costelas só 7 estão fixadas SEPARADAMENTE sobre o esternuom [sic], pela frente. (ver fig. 3 "caixa torácica) As restantes, as 3 falsas costelas estão unidas "conjuntamente" ao esternuom [sic] por um cartílogo [sic] e as costelas flutuantes estão livres.

$\mathrm{Na}$ inspiração ao enchermos de ar os pulmões, as costelas se separam e a caixa torácica se dilata.

O diafragma é um músculo transversal que separa a caixa torácica da abdominal. (LÉBEIS, s.d., CML-15, p. 27-28) 


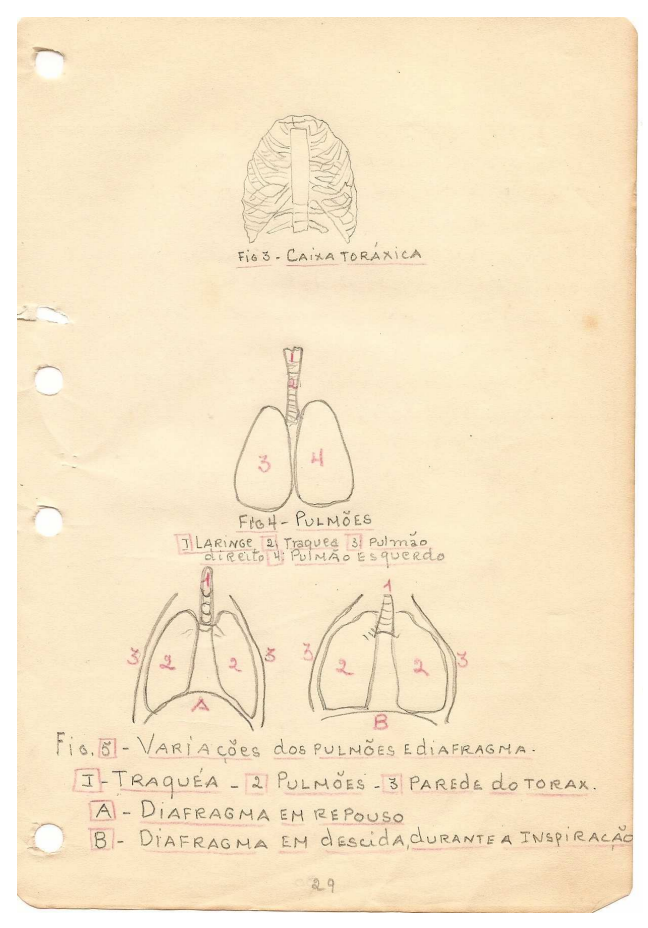

Fig. 20 CML-15, p. 29

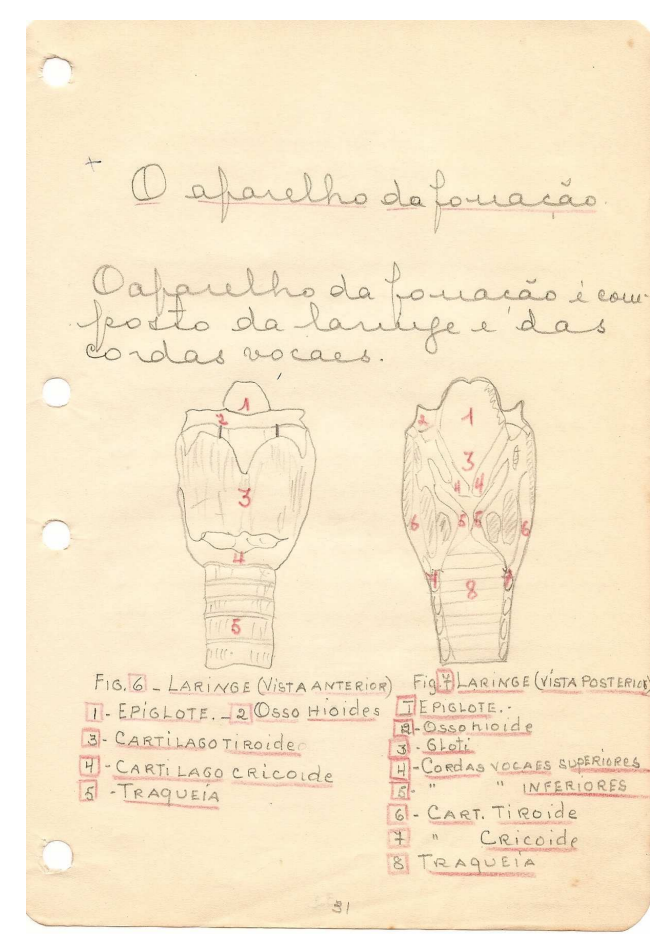

Fig. 21 CML-15, p. 31

A Laringe faz a continuação da traquéia prolongando-a até encima. Situada no interior do pescoço a laringe dá lugar a uma saliência denominada: "maça de Adão". Sua forma é de um tubo, cuja parte mais estreita, adaptada à traquéia, é (ocluída ?) [sic] pelas pregas vocais quando estas se põe a vibrar. Numerosos ossos, ligamentos, cartílogos formam a laringe. Os ingleses dão a laringe o nome de "voice-box" que quer dizer "caixa da voz". Ela é sem dúvida a fonte da voz.

Chama-se gloti o espaço compreendido entre as bordas livres dos ligamentos - cordas vocais. A Gloti se abre para a aspiração e fecha-se para a fonação. (ver Fig. 8)

O som produzido só pelas cordas vocais é muito pequeno. Para adquirir seu brilho, amplitude, redondez [sic], deve passar pelos ressonadores [sic], assim como o som produzido por uma corda de violino deve ressonar na caixa de madeira do instrumento musical.

Quais são, os ressonadores [sic] da voz humana? São muito numerosos e, sem exagero podemos dizer que o esqueleto inteiro toma parte na ressonância vocal.

Os ressonadores [sic]mais importantes encontram-se nos ossos da cabeça e são: Palato ósseo, os sinos, (maxilares etc) e a faringe.

Nas notas graves, os ossos do peito dão também grande riqueza à ressonância.

A beleza da voz, o timbre a amplitude, dependem muito mais da qualidade dos ressonadores [sic] que das cordas vocais. (LÉBEIS, s.d., CML-15, p. $33,34,37)$ 


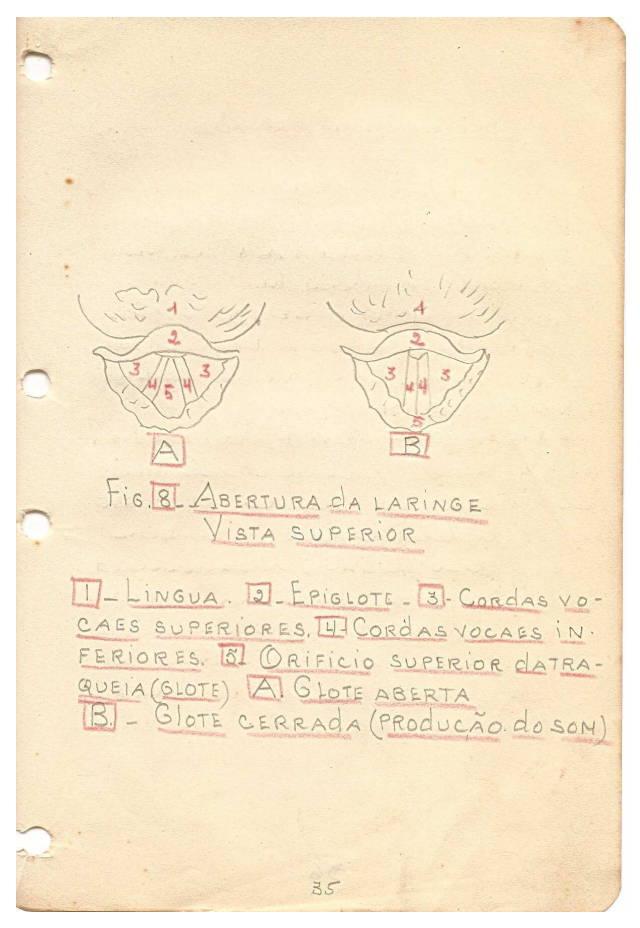

Fig. 22 CML-15, p. 35

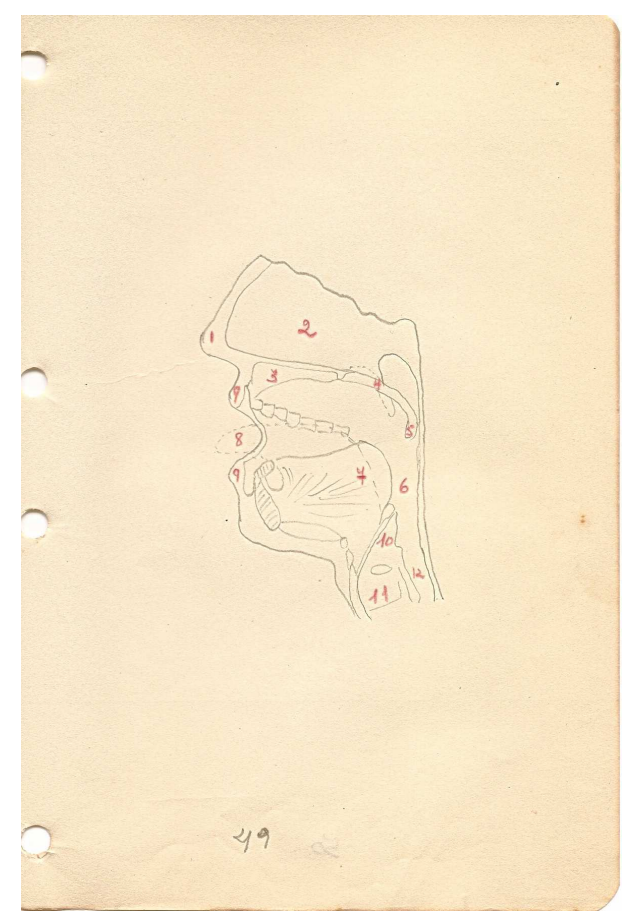

Fig. 23 CML-15, p. 49

Depois de observarmos os desenhos feitos por Lébeis e algumas entre as muitas considerações escritas por ela a propósito da anatomia e do funcionamento do instrumento vocal, nos parece não restar dúvida do comprometimento desta artista e educadora com a busca de um domínio da técnica por meio do conhecimento do aparato vocal.

A pedagogia baseada, essencialmente sobre a interpretação, obtém bons resultados com cantores instintivamente bem coordenados (seria excessivo estimar a proporção de aproximadamente $1 \%$ ?), que possuam um domínio admirável dos requisitos da técnica vocal. (MILLER, 1990, pg. 230, tradução do autor) ${ }^{29}$

29 "La pedagogie essentiellement fondée sur l"interpretation obtien de bons resultats auprès des chanteurs intinctivement coordenés (est-il excessif d'estimer leur proportion à environ $1 \%$ ?) qui possède déjà une amirable maîtrise des exigences de la technique vocale". 
Com esta afirmação não queremos passar a falsa idéia de que Lébeis era uma profunda conhecedora de anatomia nem que recorresse exclusivamente a explicações anatômicas quando tratava de elementos técnicos, mas sim o quanto ela estava em consonância com os conhecimentos mais avançados de seu tempo e o quanto se empenhava em compreender a realidade física do seu próprio instrumento, como consta no conteúdo do Fichário 15, aqui abordado é explicitamente elaborado para que seja lido e compreendido por outrem. "[...] Assim como nas minhas lições me faço entender pelos meus discípulos, quero que esta obra consiga o mesmo do leitor" (LÉBEIS, s. d., CML-15, p. 2)

\subsection{ELEMENTOS TÉCNICOS - Respiração e Apoio.}

Podemos observar que a busca por uma respiração adequada e que possa prover um melhor aproveitamento do ar, conduzindo à melhoria da qualidade sonora, não é assunto recente neste campo de estudo. Os célebres tratados de canto - tanto os do passado, como os de Caccini, Tosi, Garcia, e também recentes pesquisas continuam privilegiando a respiração e o apoio em seus conteúdos técnicos e analíticos.

Neste item trataremos de um aspecto bastante específico do conteúdo técnicovocal, diretamente ligado à questão respiratória: o apoio.

Percebemos a importância dada por Janacópulos e por Lebeis para a questão respiratória ao observar que logo na primeira aula esse tópico já abordado e segue, durante anos de estudo, comentado e relembrado insistentemente como um elemento fundamental no processo técnico descrito por Lébeis.

Ela [Janacópulos] fez primeiro um esboço da qualidade do som. Fez uma verdadeira conferência anatômica. Perguntou-me se eu tinha para cantar alguma maneira de respirar diferente da que uso para falar - Respondi-lhe que não havia reparado que eu apenas já sabia calculá-la afim de não acabar um trecho sem fôlego. Em seguida continuou: "nós devemos respirar normalmente sentindo estufar os lados, alargamento do tórax. (LÉBEIS, $1937,1^{\text {a }}$ aula, grifo do autor) 
A citação acima nos esclarece primeiramente que Janacópulos, segundo o relato de Lébeis, possuía um conhecimento aprofundado e objetivo das questões relativas à fisiologia vocal. Várias são as questões pertinentes à respiração que poderiam se desdobrar a partir deste breve ou brevíssimo relato referente à primeira aula. Repare que Lébeis ainda não usa a palavra apoio nessa primeira aula.

$\mathrm{Na}$ segunda aula, neste início do primeiro caderno, ainda descrita como segunda lição, Lébeis considera:

Fui hoje novamente ao Municipal receber outra aula de Dona Vera. Achei dificílimas as suas explicações. No exercício:

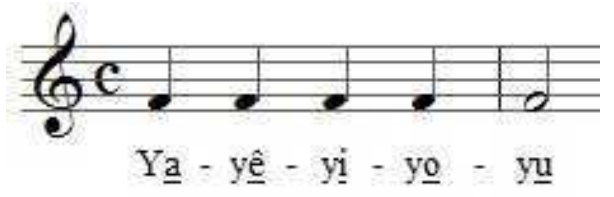

Ex. 1 - Exercício proposto na $4^{\mathrm{a}}$ aula.

Dona Vera quer que se cante sentindo levemente o alargamento do tórax, porém, sem interrupção de uma nota para outra. Quer que todos os sons sejam ligados e no mesmo plano. [...] (LEBEIS, 1937, $2^{\mathrm{a}}$ aula, grifo do autor)

Como podemos observar, segundo Lébeis, Jancópulos fala em "alargamento do tórax", pelo menos naquele momento. A palavra "apoio" surgirá pela primeira vez apenas na página 16 do primeiro caderno, seguida de outras considerações sobre a respiração:

\footnotetext{
Como se constitui a respiração:

I - No mesmo tempo que se respira o diafragma vai se estendendo.

II - alarga-se o tórax com o apoio

III - Assim constitui o armazenamento da respiração.

IV - Significa a pressão da respiração contra os músculos do peito, ou por outra, contra os músculos de "resistência" do peito. (LEBEIS, 1937, 4ª aula, grifo do autor)
}

Esta não é apenas a primeira vez que a palavra apoio aparece, mas também é um momento em que Lébeis associa - não por iniciativa exclusiva, mas pelo material 
teórico do qual fazia uso - a palavra "apoio" ao "alargamento do tórax", anteriormente relatado e aconselhado pela mestra Janacópulos, discípula de Lehmann, autora original dos desenhos e dos conceitos expressos junto a eles.

Salientamos o fato de a palavra apoio aparecer não apenas na mesma frase ou associada ao "alargamento do tórax", ou sequer por uma mera questão geográfica na construção do texto. Aqui, aparece claramente a afirmação de que o alargamento do tórax é o próprio apoio, ou pelo menos parte integrante deste recurso técnico, lembrando que não estamos afirmando ser este o conceito de apoio, mas ser este o conceito expresso por Lébeis.

As observações de Lébeis, ainda que não faça referencia nesse momento, são provenientes do livro de Lehmann, que ela citará em outras oportunidades. Segue junto às considerações um desenho também extraído do citado livro e copiado à mão por Lébeis.

Observemos o desenho seguinte e, nele, também os números que fazem referência aos itens descritos na citação anterior.

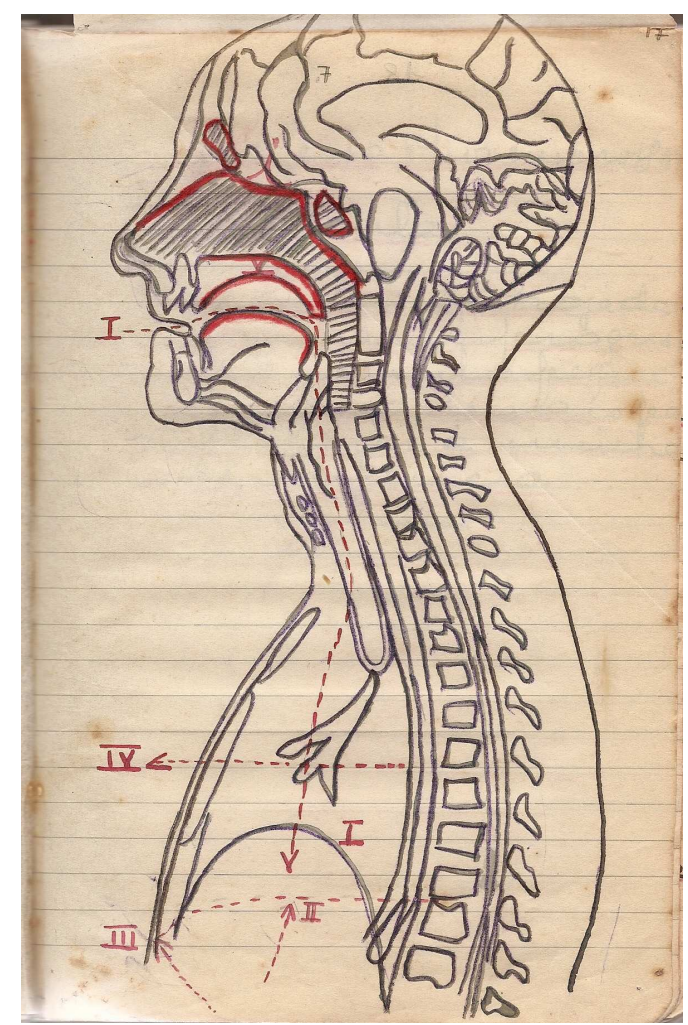

Fig. 24 - Lébeis, primeiro caderno de aulas, p. 17. 
Cantei a seguinte vocalize

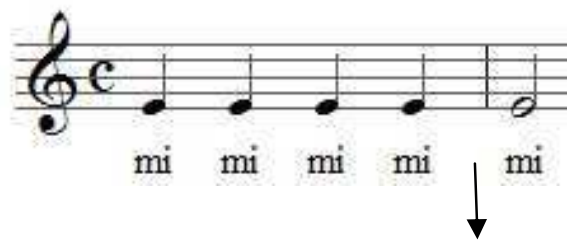

Respirar, aumentar com apoio e alargar o tórax. (Lébeis, 1938, 91ª aula).

Ex. 2 - Exercício proposto $91^{\text {a }}$ aula.

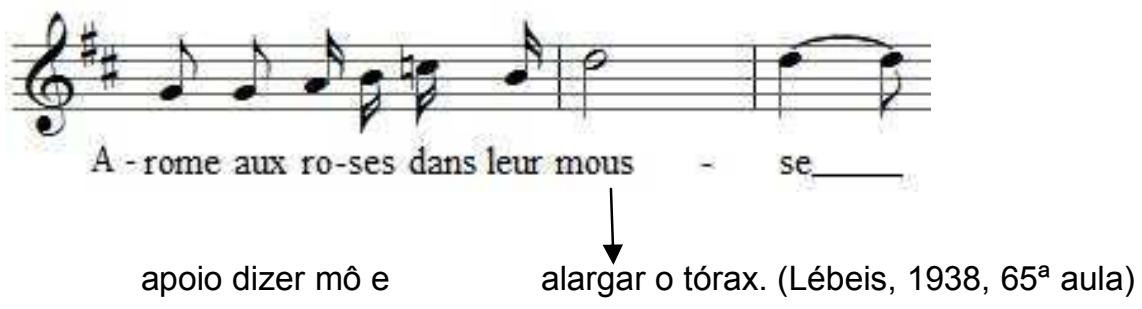

Ex. 3 - Exercício proposto na $65^{\mathrm{a}}$ aula.

A citação anterior é um dos únicos momentos, dentro dos limites do primeiro caderno, que encontramos o termo "apoio" aparentemente representando algo apenas associado ao alargamento do tórax. Notemos que Lébeis escreve "apoio e alargamento do tórax", possivelmente sugerindo alguma diferença entre as duas coisas; porém, no decorrer das aulas relatadas no primeiro caderno - e estas compreendem uma maior atenção as questões técnicas, principalmente no tocante aos principais conceitos - o que percebemos é uma aparente utilização de "apoio" e "alargamento do tórax" como sinônimos. Vejamos, porém, um exemplo onde existe uma aparente separação entre alargamento e apoio.

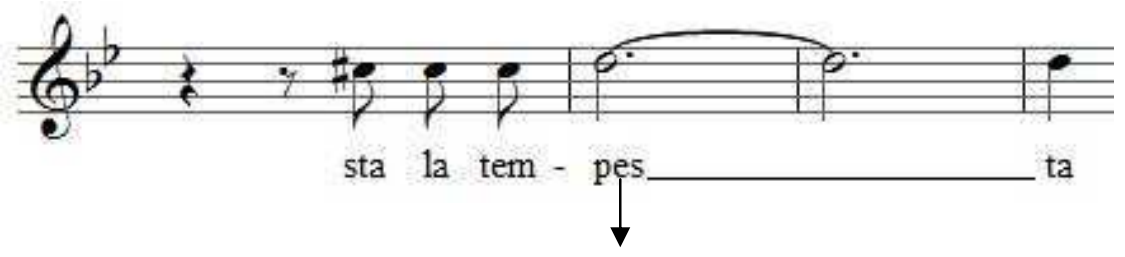

mudar as vogais e-o-u fazer o crescendo da nota com o alargamento do tórax, apoio, muita maleabilidade, muita altura, queixo mole e narinas abertas

Ex. 4 - Exercício proposto na $16^{\mathrm{a}}$ aula 
Normalmente, o que ocorre nas dezenas de exemplos que poderiam ser extraídos do primeiro caderno é a palavra apoio surgir isoladamente; o mesmo ocorre com a recomendação de alargar o tórax; resta certa inquietude do pesquisador (e talvez houvesse também por parte de Lébeis) quanto a esta questão, porém neste último exemplo poderíamos também facilmente interpretar a vírgula que separa "alargamento do tórax" e "apoio" apenas como uma maneira encontrada por Lébeis de enfatizar o recurso técnico exigido naquela situação. Esta segunda idéia parece mais acertada.

Existe uma aproximação entre conceitos e procedimentos que serviram ao trabalho de Lébeis e que permanecem bastante atuais.

No apoio, a região situada entre o esterno e o umbigo sobressai durante a inspiração, mas o principal movimento de expansão se produz no plano lateral. Esta ação não consiste em empurrar para fora o baixo ventre (zona hipogástrica ou pubiana) assim como fazem certas técnicas respiratórias. Depois da expansão inicial começa um movimento quase imperceptível através do interior, salvo se opusermos uma resistência voluntária em compensação da pressão sentida no nível do umbigo, dos flancos e da parte interior das costas. O tórax permanece estável e quase nenhum movimento se faz sentir no plano lateral; ao fim de uma longa frase, evidentemente, se produz um movimento de entrada do abdome. A gente deve ter consciência na inspiração de uma expansão transversal, resultante de um antagonismo dos músculos aterolaterais. Estes músculos compreendem aqueles da cinta do abdominal reto, o músculo abdominal reto, os músculos externo e interno do abdome. ${ }^{30}$

Uma dilatação lateral é sentida ao nível da décima costela e logo abaixo, entre a décima costela e a crista ilíaca (ilium). O equilibrio da ação dos músculos é

30. Dans l'appoggio, la region située entre le sternum et le nombril ressort durant l'inspiration, mais le principal mouvemment d'expansion se produit sur les plans latéraux (voir Fig. 1.3, pour la définition des régions du torse et de l'abdomen). Cette action ne consiste pás à pousser vers l'avant le bas-ventre (zone hypogastrique ou poubienne; voir Fig. 1.3), ainsi que cela se fait dans certaines techniques de respiration. Après l'expansion initiale commence um mouvement presque imperceptible vers l'intérieur, sauf si on lui oppose une résistence volontaire par une compensation de pression ressentie au niveau du nombril, des flancs, et du bas du dos. Le tórax reste stable, aucun mouvement ne se fait quasiment sentir sur les plans lateraux; à la fin d'une longue phrase, evidement, se produit um mouvement de rentrée de l'abdomen. On doit avoir conscience, em inspirant, d'une expansion transversale, resultant de l'antagonisme des muscles antéro-latéraux. Ces muscles comprennent ceux de la gaine de l'abdominal droit, le muscle droit de l'abdomen, les muscles oblique externe et interne, et le muscle transverse de l'abdomen. 
sentido nas zonas anteriores (tórax, epigástrio, região umbilical) e laterais posteriores. (MILLER, 1990, p. 27, tradução do autor) ${ }^{31}$

Quando Janacópulos, por meio do relato de Lébeis, fala em "nós devemos respirar normalmente sentindo estufar os lados, alargamento do tórax" (LÉBEIS, 1937 p. 2), ela se refere ao mesmo movimento classificado por Miller como principal movimento de expansão e demosntra, sobretudo, o grau de objetividade da linguagem usada para comunicar o procedimento técnico referente ao elemento tratado.

São numerosos os exemplos onde o apoio é aconselhado seguido ou não da recomendação de alargamento do tórax. Ao ver alguns destes exemplos, atentemos também para frequência, e aqui serão apresentados apenas alguns dos muitos exemplos em que tal recomendação e a palavra "apoio" aparecem ligadas, ao menos espacialmente à palavra "altura", esta última não menos presente no relato de Lébeis e, em nossa opinião, primeiramente associada à ressonância vocal.

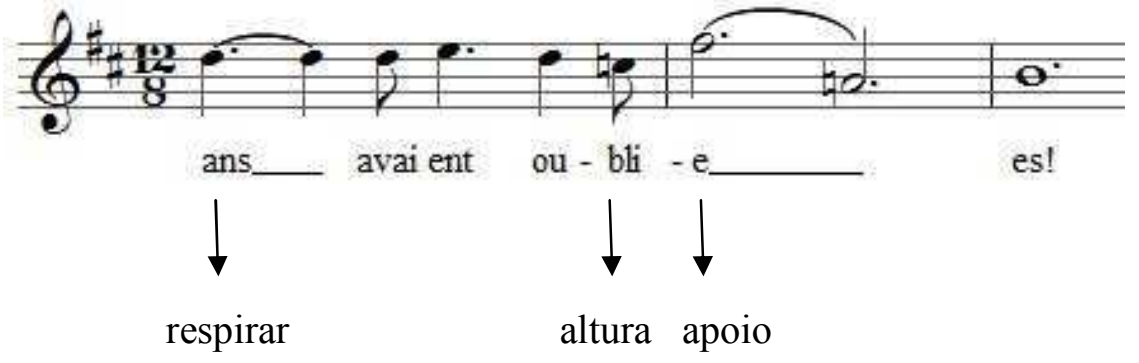

Ex. 5 - Exercício proposto na $37^{\mathrm{a}}$ aula.

Dona Vera apenas corrigiu a parte vocal.

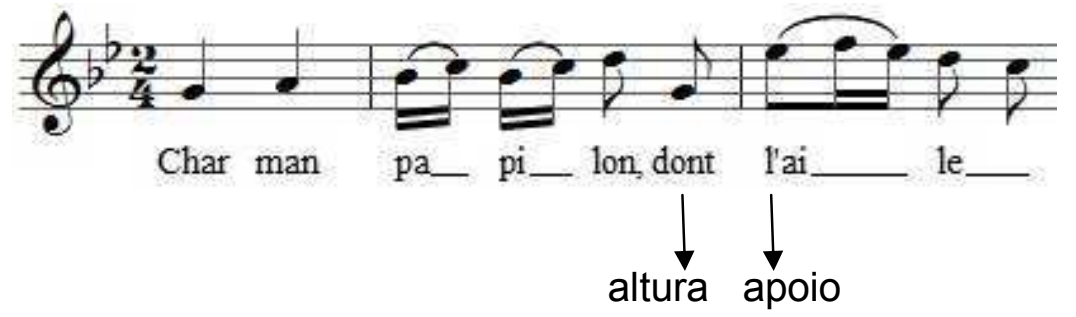

Ex. 6 - Exercício proposto na $43^{\mathrm{a}}$ aula.

\footnotetext{
31. Une dilatation latérale est ressentie au niveau de la dixième côte et immédiatement en dessous, entre la dixième côte et la crête de l'os iliaque (ilium). L'équilibre de l'action des muscles se fait sentir à la fois de zone antérieur (torax, épigastre, région ombilicale) et latéro-postérieres.
} 


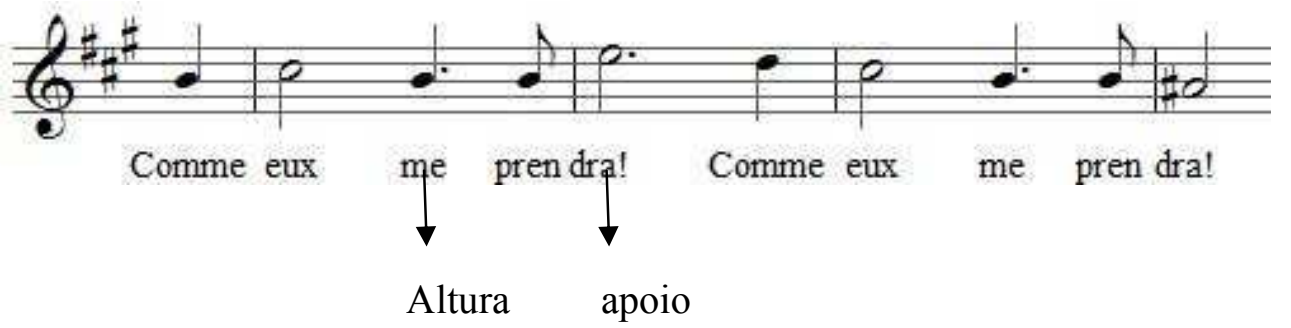

Ex. 7 - Exercício proposto na $52^{\mathrm{a}}$ aula.

\section{Observações minhas (Lébeis)}

(24 maio 1938)

Hoje cedo, ao fazer minha hora de vocalize notei grandes melhoras que me deixaram muito satisfeita. $O$ exercício de terça de boca fechada está bem. Estudei como Dona Vera mandou. Fazer três a quatro vezes a nota de cima até ela sair sem precipitação de sonoridade que sempre é provocada por excesso de sopro. Depois, cantar tal qual ele é, pensando nas seguintes coisas: altura, alargamento do tórax, apoio, boca na mesma abertura tanto nos agudos como nos graves, língua tranquila, queixo flexível e quando subir lembrar do ju. (LÉBEIS, 1938, primeiro caderno de aulas, p. 115-116, grifo do autor)

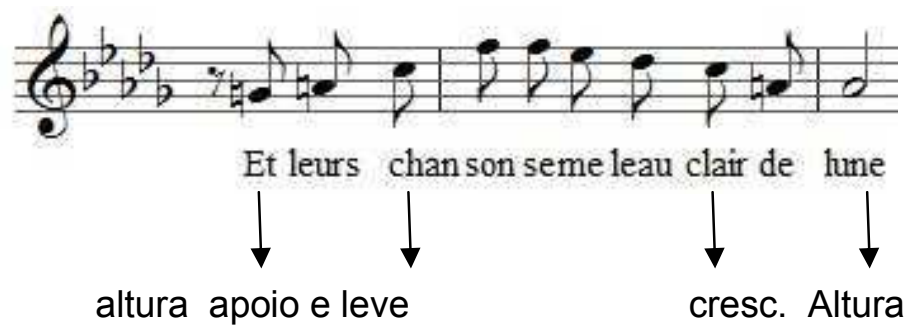

Ex. 8- Exercício proposto na $52^{\mathrm{a}}$ aula.

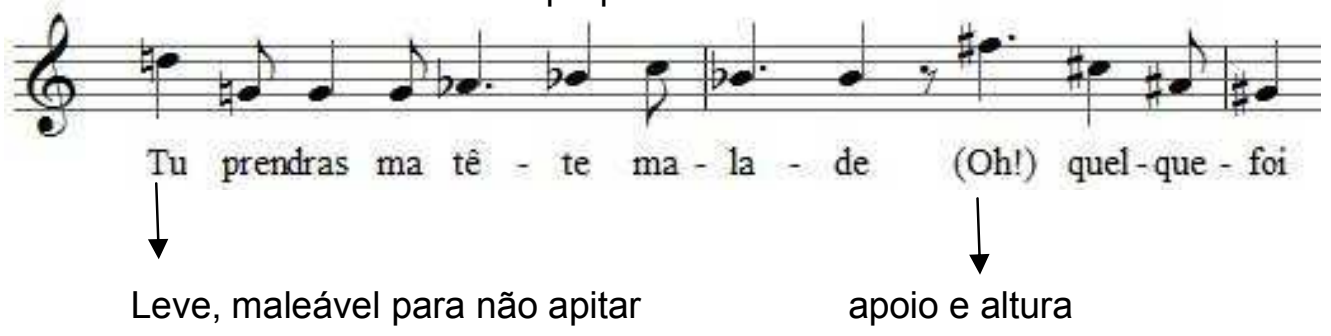

Ex. 9 - Exercício proposto na $102^{\mathrm{a}}$ aula 
A pedagogia moderna de canto - e neste caso nos referimos especialmente a Miller, que nos serve de referencia teórica para as análises - compreende a respiração e conceito de apoio de maneira muito objetiva, embasada por um avanço no conhecimento da fisiologia da voz que somente pode ocorrer devido ao desenvolvimento tecnológico e médico alcançado em nosso tempo, sem esquecer a possibilidade que o acesso ao material produzido por antecessores históricos permitiu para a evolução desses conhecimentos.

Miller deixa claro que não devemos pensar o apoio como um evento motor isolado da ressonância da voz e afirma ser esta a concepção da escola histórica italiana. Salientamos ainda que não podemos afirmar que Lébeis possuía total clareza a esse respeito; nos relatos registrados, percebemos que, mesmo que na maioria das vezes as idéias de apoio e de ressonância apareçam separadas, em alguns momentos tais conceitos aparecem tão próximos que ponderamos a hipótese de que, ainda que conceitualmente Lébeis tratasse esses quesitos técnicos separadamente, no exercício dos procedimentos de execução, por vezes, pareceram fortemente associados.

A escola italiana internacional se caracteriza por uma concepção admiravelmente uniforme da administração do fôlego que, dominou a história do canto no século vinte. O l'appoggio não pode se definir como pensamos frequentemente apenas por "suporte respiratório", o sentido próprio do termo, visto que apoio concerne também o domínio da ressonância tanto quanto do ar. [...] A escola italiana histórica não conhece distinção entre o aspecto motor e os aspectos ressoadores que outras escolas praticavam, o apoio é um sistema que permite equilibrar os músculos do colo, controlando suas relações com os ressoadores situados a cima da glote, sem exagerar uma função em relação à outra no domínio do todo. [...] No que concerne à administração do ar, l'appoggio consiste em conservar ao longo de um período dado uma postura próxima aquela que prevalece no inicio do ciclo respiratório. Esta postura inicial garante a participação dos músculos da zona peitoral, epigástrica e umbilical, bem como o controle diafragmatico. $O$ tronco inteiro participa. A poderosa musculatura abdominal sustenta o mecanismo respiratório. [...] (MILLER, 1990, p. 26, tradução do autor) ${ }^{32}$

32 . L'école internationale du chant italien se caracérise par une conception étonnamment uniforme de la gestion du soufle, qui a dominé l'historie du chant au 20 e siècle. L'appoggio ne peut se définir, ainsi qu'on 
Optamos, no exemplo a seguir, por usar uma reprodução fac-símili, pois há um desenho feito à mão por Lébeis para ilustrar o procedimento durante a realização do exercício. No nosso entendimento este é o momento onde mais claramente apoio e ressonância aparecem associados. Lembramos mais uma vez não se tratar de uma afirmação no sentido de Lébeis compreender tal aspecto técnico de forma idêntica a Miller, mas enxergamos um apontamento para um mesmo tipo de compreensão.

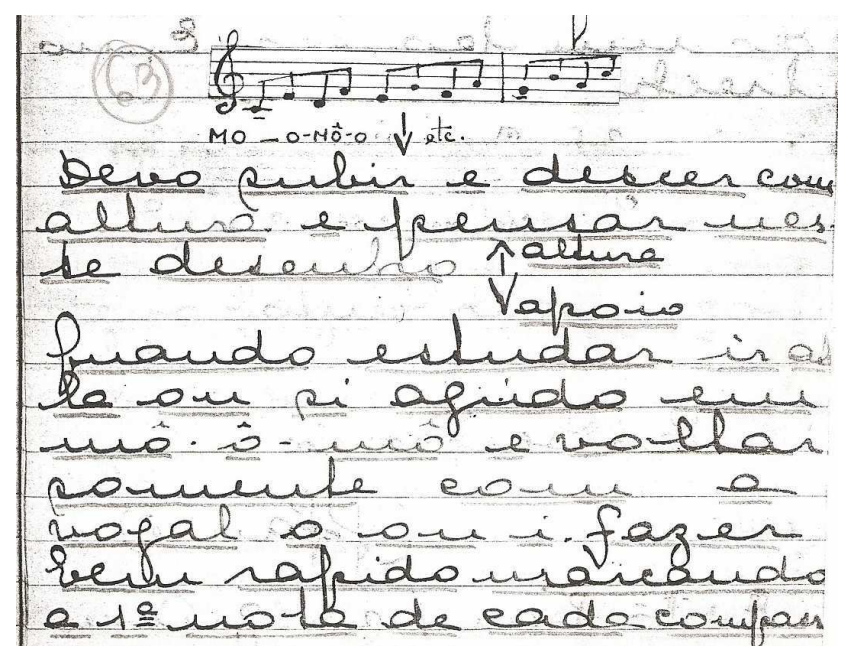

Fig. 25- Página do primeiro caderno de aulas, referente à aula de número 37 .

Na próxima citação, extraída ainda da primeira aula, encontramos várias outras que continuam tomando lugar nos trabalhos teóricos atuais e ocupando aqueles que se dedicam a esta área de estudo.

Não encher por completo os pulmões de ar, pois quando os enchemos em demasia, a qualidade do som não sai redondo devido ao excesso de ar. [...] É curioso fazer esta experiência numa só nota: deu um fá agudo com a boca meio cerrada, saiu estridente, depois, na mesma respiração sobre a mesma

le pense souvent, en tant que -"soutien respiratoire" au sens propre du terme, car l'appoggio concerne aussi bien le domaine de la ressonance que celui du soufle. Appoggio peut se traduire par "appui" (appoggiarsi a, "sappuyer sur"). L'Ecole Italiene historique ne connaissait pas la distinction entre l'aspect moteur et les aspects ressonateur que d'autres écoles ont pratiquée. L'appoggio est un systèrme permettant de combiner et d'équilibrer les muscles du tronc e du cou, en contrôlant leur relation avec les réssonateurs situés au-dessus de la glotte, sans que l'exageration d'une fonction par rapport aux autres ne vienne dominer le tout. 
nota arredondou a boca alargando o tórax com elasticidade tornado o som aveludado e sonoro. [...] (LÉBEIS, 1937, $1^{\text {a }}$ aula, grifo do autor)

Não encher por completo os pulmões, por exemplo, é algo que no passado já se pensou diferentemente. $O$ trabalho de Pacheco (2006) nos serviu de importante fonte para algumas constatações :

Algo digno de nota é que Garcia aconselha a respiração completa, ou seja, além do abaixamento do diafragma e do afastamento das costelas, indica uma elevação do peito, isso não costuma ser indicado pelos professores de canto modernos. (PACHECO, 2006, p. 92)

Percebemos aqui a atualização de Janacópulos e de Lébeis com o seu tempo e notamos que o trabalho que ela desenvolve sob a orientação de Jancópulos já se beneficia de evoluções conceituais e procedimentais no estudo do canto.

"Pediu-me para respirar da seguinte forma: "nunca deixar que os ombros ouçam a minha respiração" (Lébeis, 1937, $1^{\text {a }}$ aula). Essas palavras relatadas por Lébeis nos esclarece perfeitamente que ela não usava uma respiração completa, como aquela sugerida por Garcia; havia uma preocupação muito clara em não encher demais os pulmões e evitar uma dilatação clavicular. Evidentemente, hoje em dia não aceitamos no procedimento pedagógico uma terminologia quase que poética, como a usada neste caso por Lébeis, ou por Janacópulos, já que se trata de uma transcrição da aula ministrada por Janacópulos, no entanto, ainda que subjetiva do ponto de vista da realidade física, tal recomendação técnica da mestra é facilmente entendida e nos esclarece quanto ao seu procedimento.

$\mathrm{Na}$ inspiração destinada ao canto os pulmões não devem dar a impressão de estarem repletos, mas satisfeitos. Ewald Hering e Joseph Breuer foram os pioneiros no estudo do controle reflexo da respiração. Eles voltaram a atenção para os aspectos sensoriais das conduções reflexas ligadas aos pulmões. ${ }^{33}$

\footnotetext{
33. Dans l'isnpiration destinée au chant, les poumon ne doivent jamis donner l'impression d'être remplis, mais satisfaits. Exald Hering e Joseph Breuer furent les pionniers de l'étude du contrôle réflexe ded la respiration. Ils attirent sur les aspects sensoriels des conductions réflexes reliées aux poumon [...] (Miller, 1990, p. 30 trad. para fracês de Jean-Marie Gouëlou )
} 
[...] Encher os pulmões implicara numa grande velocidade de expiração. $\mathrm{O}$ cantor tomando uma respiração cômoda, "restituindo" assim a respiração, terá fôlego maior que aquele que "encher" seus pulmões de ar. Mesmo no caso de uma longa frase os reflexos respiratórios serão melhor controlados se o cantor evitar uma dilatação exagerada. A expansão clavicular da a impressão de que os pulmões estão repletos de ar, porem esta sensação é de fato provocada pela tensão muscular, e não pela expansão dos pulmões. [...] (MILLER, 1990, p. 30 , tradução do autor) ${ }^{34}$

"Quando encher o pulmão seguir logo com a nota passando de uma vogal para outra suavemente" (Lébeis, 1937, 1ª aula). Por meio deste comentário, mais uma vez, Lébeis demonstra quanto seu trabalho, no tocante à questão específica que tratamos neste momento - não reter o ar -, permanece atual e quanto a comunicação entre discípula e mestra, ao se tratar de elementos pertinentes à técnica se mostra prioritariamente clara e objetiva.

Não devemos ter a impressão inicial de reter a respiração, nem de se prender cantando. Se um cantor sente uma extrema resistência muscular no momento da inspiração, seja ao nível do peito ou do abdome, a causa não é uma respiração "plena" ou "profunda"; mas um antagonismo muscular inútil. A glote se comporta como uma simples válvula e é pelo seu fechamento que ela reage, todas as sensações se produzem ao nível das costelas e do abdome. Isso deve ser evitado durante o canto. (MILLER, 1990, p. 29, tradução do autor) ${ }^{35}$

34. "Remplir" les poumons impliquera une plus grande vitesse d'expiration. Le chanteur prenant une respiration aisée, "remplaçant" ainsi le soufle utilisé, aura une plus grande longueur de souffle que celui que "remplit" ses poumon d'air. Même dans le cas d'une longue phrase, les réflexes respiratoires seront mieux contrôlés si le chanteur évite toute dilatation exagérée. La respiration claviculaire donne l'impression que les poumons sont gonflés d'air, alors que cette sensation est en fait provoquée par la tension des muscles, et non par l'expansion des poumon.

35 . On ne doit jamais avoir l'impression initale de retenir son soufle, ni de s'y accrocher en chantant. Si un chanteur ressent une extrême résistance musculaire à l'inspiration, que ce soit au niveau de la poitrine ou de l'abdomen, la cause n'en est pas une respiration "pleine" ou "profonde"; mais c'est qu'un antagonisme musculaire inutile intervient. La glotte se comporte come un simple valve, et c'est par sa fermeture d'elle réagit, normalement, à toute tension se produit au niveau des côtes ou de l'abdomen. Cela doit être évité en chantant. 
Outra questão pertinente à respiração presente em tratados do passado, no relato de Lébeis e também em trabalhos atuais é o fato de a respiração causar ou não ruído. Na próxima citação perceberemos o que Lébeis almejava a este respeito.

Preciso prestar muita atenção no exercício que esta na página anterior. (mame-mi-mo-mu) a sonoridade do mi está estridente, preciso arredondar mais a boca e sentir o queixo bem para traz. Na bergerrette, não ouvir a respiração. (LÉBEIS, 1937, $7^{a}$ aula, grifo do autor)

Comparando questões respiratórias contidas nos tratados de canto de Tosi, Mancini e Garcia, Alberto Pacheco (2006, p. 91) considera que Garcia se preocupava com o ruído tanto na inspiração lenta quanto na instantânea: "em ambos os casos, a passagem de ar pela garganta não deve causar, nem mesmo o mais leve sussurro, que prejudicaria o resultado do canto e causaria secura e rigidez a garganta."

Miller (1990, pg. 31) é bastante enfático quanto a questão do ruído respiratório e não apenas condena esta pratica, como explica detalhadamente as questões fisiológicas envolvidas naquela situação.

Uma inspiração silenciosa é a marca do l'appoggio. O barulho da respiração é causado pela resistência da garganta contra a passagem do ar inspirado. Ainda que a tomada do ar seja rápida ou articulada sobre um momento mais longo (qualquer que seja sua retomada) pelo nariz (esta demanda mais tempo) ou pela boca, o processo de inspiração do l'appoggio permanece o mesmo. A respiração do cantor deve antes de tudo ser inaudível.

Logicamente, poderíamos dizer que todas as técnicas de canto trazem uma certa proximidade, funcionalmente eficaz da administração do fôlego, e que os profissionais que se ocupam dos cantores consideram a respiração silenciosa como parte integrante de uma emissão vocal correta. (MILLER, 1990, p. 31, tradução do autor) ${ }^{36}$

36. Une inspiration silencieuse est la véritable marque de l'appoggio. Le bruit de respiration, rappelonsle, est causé par la résistence de la gorge au passage de l'air inspiré. Que la prise de soufle soit rapide ou répartie sur un moment plus long (quelle que soit sa répartion), par le nez (ce qui demande plus de temps) ou par la bouche, le processus d'inspiration de l'appoggio reste le même. La inspiration du chanteur doit avant tout être inaudible.

En tout logique, on pourrait se dire que toutes les techniques de chant comprennet une telle approche, fonctionnellement efficace, de la gestion du soufle, et que les personnes ayant professionnellement à s'occuper de chanteurs considèrent l'inspiration silencieuse comme partie intégrante d'une émission vocale correcte. 
Quanto à linguagem relatada no primeiro caderno de aulas a respeito da comunicação dos elementos técnicos, se pode observar tratar-se de uma linguagem híbrida, na qual havia a preocupação em explicar a técnica baseada na realidade física, mas também há registros do uso de linguagem metafórica na comunicação de elementos da técnica.

Cabe ressaltar que, especificamente sobre os elementos analisados - respiração e apoio - os registros demonstram o uso de uma linguagem objetiva e baseada nas informações sobre a fisiologia da voz que Janacópulos conhecia. 


\section{CAPÍTULO 3: Elementos Interpretativos.}

Quando nos voltamos para observar e analisar aspectos relativos à interpretação descritos nos cadernos de aulas de canto de Lébeis, nos chama atenção uma diferença bastante clara entre as abordagens técnica e interpretativa. Enquanto na abordagem técnica Lébeis procura se valer de uma linguagem objetiva ${ }^{37}$, fundamentada em informações precisas sobre funcionamento do aparelho vocal, consciente dos aspectos da fisiologia da voz, na abordagem interpretativa ela segue um caminho distinto, valorizando a subjetividade e o uso de imagens e buscando, principalmente, a compreensão poética e dramática da obra estudada, apesar de não abandonar os procedimentos e as escolhas interpretativas objetivas. Optamos aqui pela não sistematização dos recursos utilizados, por entendermos que primeiramente necessitaríamos de ferramentas de análise cujo desenvolvimento pertenceria a outro projeto de estudo e que qualquer tentativa de sistematização sem as devidas ferramentas de análise implicaria análises inorgânicas dos processos interpretativos, não desejáveis neste estudo.

Pretendemos neste capítulo iniciar uma discussão sobre processos interpretativos utilizados por Lébeis e Janacópulos e descritos nos cadernos de aulas de canto, destacar elementos de interpretação e a linguagem usada na comunicação do conteúdo interpretativo.

Convém ressaltar que, vários cantores profissionais notáveis não usem imagens fisiológicas ou psicológicas. Para eles as imagens ocorrem somente no campo da interpretação. Eles mantêm um canal duplo de orientação física e psicológica, no qual os fundamentos técnicos já estão estabelecidos e permitem projeções imaginativas do texto e da música. (MILLER, 1996, p. 4, tradução do autor) ${ }^{38}$

\footnotetext{
${ }^{37}$ Esta afirmação não ignora que "imagens" e outros recursos subjetivos também eram empregados pelas artistas, mesmo no domínio do estudo técnico.

${ }^{38}$ It shoud be remarked that many outstanding professional singers ever use detailed physchologic or techinical imagery. For them, imagery occurs only at the interpretative level. They maintain a dual channel of psychological and phsycal orientation in which the technical fondation that has already been stablished permits imaginative textual and music projetion.
} 
Nos registros de Lébeis encontramos exatamente o processo descrito por Miller, ou seja, a liberdade para o uso de imagens no campo da interpretação.

A imaginação no canto deveria ser melhor direcionada para a realização artística do texto, do drama e do conteúdo musical, não para o controle de aspectos físicos da técnica vocal. (MILLER, 1996, p. 5, tradução do autor) ${ }^{39}$

O repertório estudado por Lébeis, ou estudado e apresentado em concertos e recitais é muito variado, compreende desde obras tradicionais do repertório vocal até obras de autores modernos, contemporâneos a Lébeis, obras em diversos idiomas, tais como italiano, alemão, francês, inglês, espanhol, hebraico, grego e português. Diante da diversidade do repertório e do volume monumental dos registros sistemáticos que o contemplam $^{40}$, propomos uma análise do processo de criação da interpretação no trabalho de Lébeis, direcionada apenas as obras pertencentes ao repertório nacional e descritas nos cadernos de aulas de canto. Ainda que fossem selecionadas apenas as peças brasileiras, o volume de registros tornaria inexequível o processo analítico dentro dos limites deste trabalho, portanto foram adotados alguns critérios para fazer uma seleção dentre as peças nacionais.

Optou-se por peças que fornecessem um maior número de informações acrescentadas por Lébeis, ou seja, anotações de aulas, partituras anotadas, gravação feita pela artista. Procurou-se contemplar obras de pequenas e de grandes proporções, tendo em vista as vezes em que foram mencionadas e trabalhadas em aulas, ou apresentadas em concertos e recitais.

\subsection{TAVARES, Heckel: Saudade, Minha Terra tem.}

A atenção dispensada por Lébeis às páginas de célebres autores nacionais, por exemplo, Guarnieri, Villa-Lobos, Souza Lima, compositores de obras complexas no tratamento da linguagem, não se revela menor quando se analisa alguns dos registros

\footnotetext{
${ }^{39}$ Imaging in singin shoud ideally be directed to the artistic realization of text, drama, and musical content, not to the control of physical aspects of vocal techique.

${ }^{40}$ Registros sistemáticos das aulas, programas de concertos e recitais e artigos publicados em jornais, criticas respectivas as apresentações.
} 
referentes ao estudo de obras de autores como Heckel Tavares, compositor cujo legado está muito mais associado a uma música ligeira de fácil compreensão e de caráter mais popular. Vejamos como Lébeis trata da interpretação das duas pequenas canções de Tavares aqui selecionadas.

Aula divina tive eu hoje! Dona Vera estava um sonho, eu, entusiasmada pela Arte e além do mais fui acompanhada pelo Fritz Jank. Cantei "La vague et la cloche", "Mon ame croyante", "Repouse d'une épouse sage", "Saudade" de Heckel e "Canção do Mar" de Fernandez. Voltei da casa de Dona Vera com alma em chama, com o coração iluminado! O meu desejo era cantar pelas ruas, era cantar ao mundo o quanto me sentia feliz! (LÉBEIS, 1941, Segundo Caderno de Aulas, p. 264 -265)

$\mathrm{Na}$ citação acima, Lebeis demonstra o quanto está envolvida no processo de ensino e aprendizagem e o quanto coloca as emoções à disposição da vivência desse processo; além disso, os registros sistemáticos demonstram a clareza do procedimento no preparo do repertório.

\section{Saudade :}

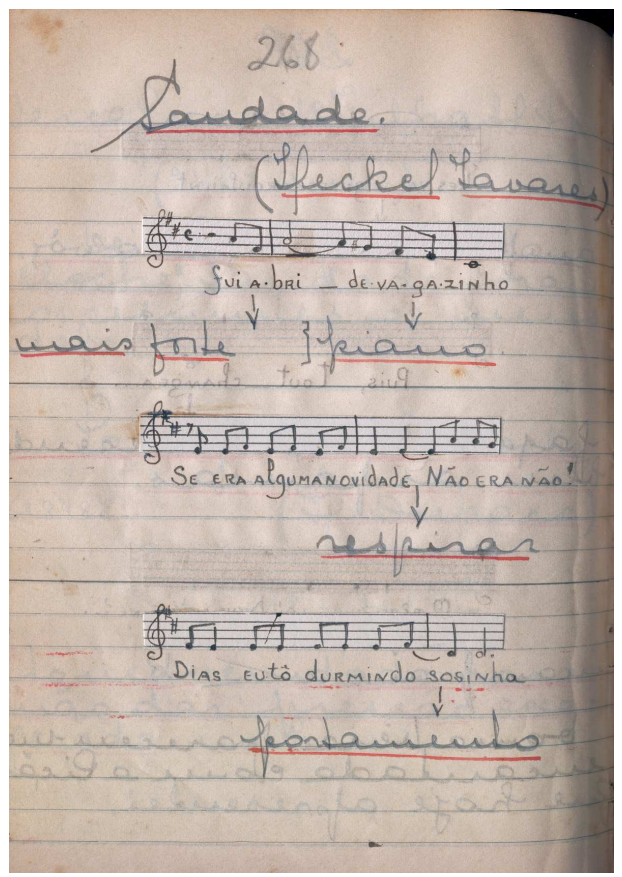

Ex. 10 - Lébeis, segundo caderno de aulas, p. 268. 
Nesta peça Lébeis usa de três recursos: dinâmica, respiração e portamento. Atribuindo um piano ao advérbio de modo "devagarzinho", Lébeis consegue um destaque para a palavra em questão. Na respiração marcada antes de "Não quero não!" é claro o uso persuasivo da retórica, quando a pausa dramática enfatiza a negativa. Por fim, o portamento descendente associado à palavra "sozinho" vem agregar, por meio de um recurso musical, valores subjetivos que estas artistas quisessem atribuir a tal condição. Diz-se "estas artistas", pelo exemplo tratar de uma aula ministrada por Janacópulos (provavelmente estamos aqui analisando uma recomendação da mestra).

\section{Minha terra tem:}

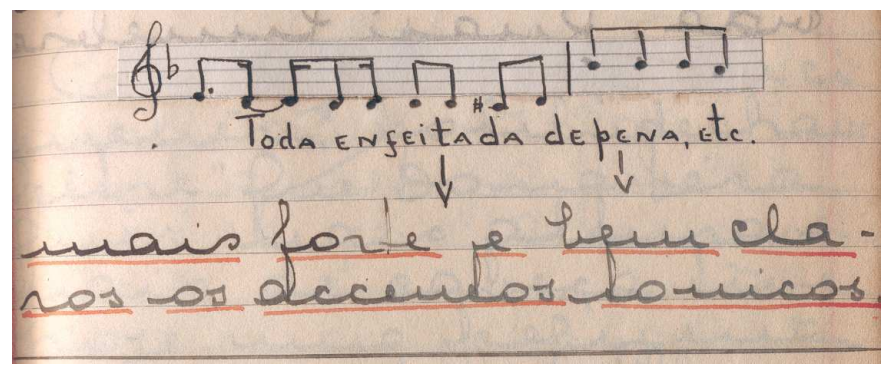

Ex. 11 - Lébeis, terceiro caderno de aulas, p. 21.

Essa música, aliás, como todas as composições do Heckel Tavares devese cantar diferente do que está escrito. [...] Suas melodias são inspiradas, porém, mal calculadas nas divisões de compasso. A orientação que se deve tomar para um estudo de uma suas composições é pensar nos acentos tônicos das palavras desde que, geralmente há pouquíssimas notas para milhares de palavras. [...]. Habituada como estou de seguir a risca as divisões de compassos, das fusas, colcheias e o estilo pessoal de cada compositor, dou pulos para estudar uma melodia de Heckel. Musica de Heckel não se lê, adivinha-se, descobre-se como Cabral descobriu o Brasil. A crítica que Dona Vera fez ouvindo-me hoje cantar "Minha terra tem" foi a seguinte: "Magdalena, que é isso, você dá-me a impressão de estar cantando Gluck ou Mozart! Isso está clássico demais, deve ser mais à vontade, uma fantasia! ..." (LÉBEIS, 1941, terceiro caderno, p. 18-21, grifo do autor) 
No exemplo transcrito por Lébeis, ela aponta o problema na prosódia e registra a necessidade de enfatizar a sílaba tônica da palavra, ainda que o compositor não a tenha escrito da maneira mais precisa. Na partitura de "Minha Terrra tem", que consta da Coleção Magdalena Lébeis, observa-se o mesmo procedimento, ela marca uma acentuação na parte fraca do terceiro tempo do compasso para evitar a distorção da palavra "caçando", com isso propõe uma leitura que vai além dos limites da grafia musical de Heckel.

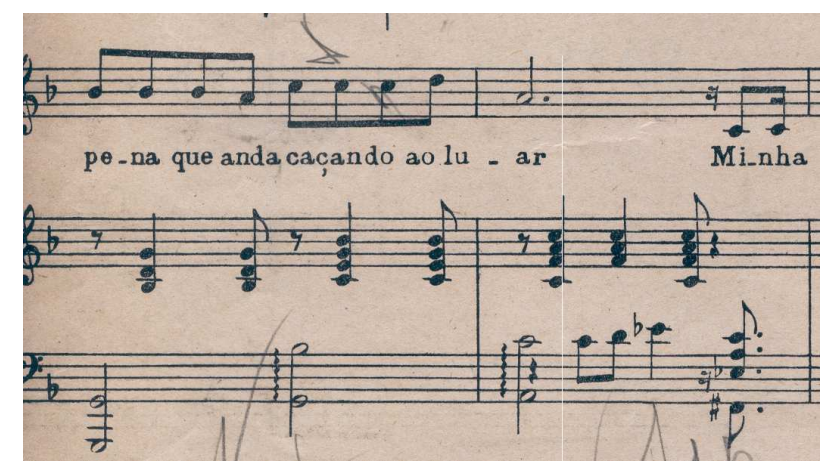

Ex. $12-C M L-933$

\subsubsection{LORENZO FERNANDEZ, Oscar: Toada p'ra você.}

\section{Poesia de Mário de Andrade.}

Todos os "que você me dá", devem ser ditos da mesma forma como quem diz: "eu sei que você me dá isso, aquilo, etc mas... eu queria mais que o "beijo molhado", queria possuir também sua alma, seu pensamento, sua sinceridade total"... (LÉBEIS, 1946, Quarto Caderno de Aulas, p. 271)

Nesta citação de Lébeis a artista demonstra o quanto compreende o sentido poético do texto de Andrade e decide permanecer atenta, durante a execução da peça, a essa compreensão cada vez que proferir as "que você me dá". No compasso de número 16 Lébeis destaca o "Ih" da palavra "molhado", neste caso certamente para fazê-lo mais devagar também, diz-se certamente, pois além dos registros escritos, há também uma gravação de "Toada p'ra você" feita por Lébeis e Jank, em que é possível confirmar esta indução. Com esse recurso, ou seja, demorando na execução do "Ih", a cantora valoriza o sentido da palavra "molhado" de maneira original e parece procurar 
demonstrar que o próprio fonema traz na sua condição intrínseca a característica "molhada".

"Pois então eu imaginei", neste trecho do poema de Andrade, Lébeis escreve na partitura: "linguagem de olhar" 41 . Ela usa, portanto, o recurso que aqui denominamos de "mascara interpretativa": a expressão facial coerente com o texto e com a compreensão poética do mesmo, assim como com a compreensão musical em que o texto está inserido.

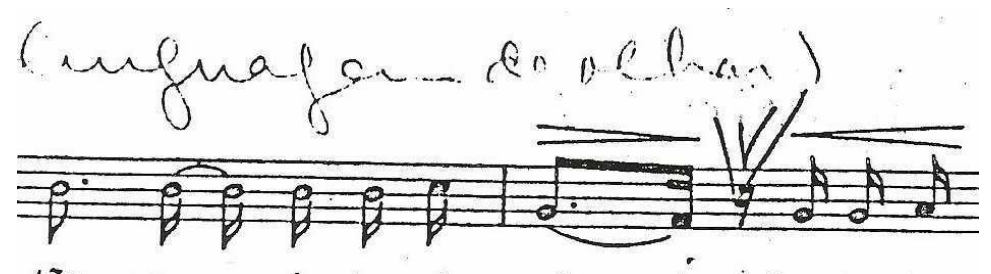

$$
\text { -tão eu i-ma-gi-nei i i Que jun_to }
$$

Ex. 13

Em "a risada que você me da" a anotação de Lébeis é quanto ao uso do "r", ela anota dois "rr" para dar maior ênfase ao substantivo.

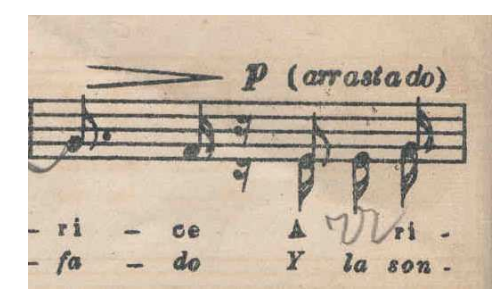

$$
\text { Ex. } 14-C M L-529
$$

Convidada pelo Conservatório Brasileiro de Música, Lébeis ministrou, em 1972, o terceiro "Curso de Interpretação do Canto" no Rio de Janeiro. Para a abertura daquelas aulas ela preparou "Efeitos da Dicção Expressiva", texto cujo conteúdo trata diretamente das questões ligadas à dicção. "Toada p'ra você" é citada como exemplo:

Devemos dobrar as consoantes, mesmo que elas (não) sejam dobradas, como habitualmente tem as línguas italiana e alemã. Em todos os idiomas precisamos dar muita atenção à cor e à força das consoantes para

\footnotetext{
${ }^{41}$ A anotação "linguagem de olhar" e o destaque dado para o 'lh" citados, foram localizados em cópia xerox de "Toada p'ra você" feita a partir de outra cópia xeróx do acervo de Prioli, a grafia parece não deixar dúvida sobre a autoria das escolhas interpretativas e provavelmente tenha sido uma anotação de Lébeis na partitura da discípula.
} 
conseguir um cunho bem expressivo. A casinha pequenina de Ernani Braga, onde se canta: "d'aquele beijo demorado, prolongado". Si catarmos "d'aquele etc", o beijo ficará sem sabor, ressabiado como se sogra e a mãe surgissem de repente... Porém, se acrescentarmos mais um "L", será um beijo de amor, sem pressa, muito mais expressivo. "que...coitado de ssauddade, etc" - torna-se maior essa saudade. Na "Toada pra você" de Lorenzo Fernandez, se puzermos mais um "b" e um "L" na frase "Nem gozar somente esse "beijo, tão molhado"... esse beijo ficará mais orvalhado de amor. A "rrisada", acrescentar "rr"aí, ficará mais risonho, o mesmo no "que me enrrabicham", tornar-se-á mais enfietiçado... Em Carlos Gomes no "Quem sabe", "tão longe", a primeira vez para expor o tema, com dicção clara, apenas articulado e, quando repete "tão Illonge" a criatura amada estará bem mais distante... (LÉBEIS, 1972, p.16-17)

As primeiras aulas dedicadas à canção "Toada p'ra você" foram as de número 300 e 302. Duzentas e setenta aulas depois, ou seja, na aula de numero 530, Lébeis retoma a mesma obra e faz a seguinte consideração:

Essa música deve ser cantada, bem balançada, arrastada por portamentos, com paixão e graça --- muitas vezes com indolência. --- Deve ser "gostosamente" extasiada... por você! ... [...] (LÉBEIS, 1942, terceiro caderno, p. 137-139)

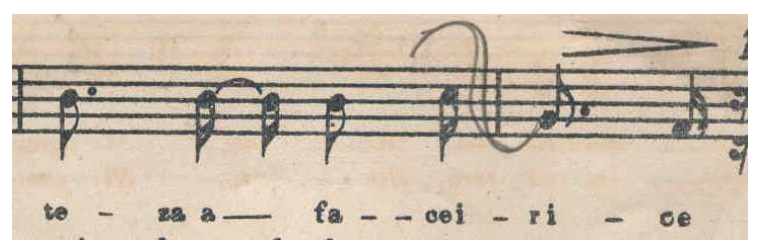

Ex. $15-C M L-529$

$\mathrm{Na}$ citação anterior, mais uma vez fica clara a consciência poética da artista sobre a obra. O uso de palavras ou expressões carregadas de sentido subjetivo, por exemplo, "com graça", "gostosamente", se misturam a determinações objetivas que corroboram as decisões interpretativas baseadas numa compreensão do sentido poético, tais como, "arrastada por portamentos". 


\subsubsection{MIGNONE, Francisco: O doce nome de você. (1941)}

\section{Versos de João Guimarães.}

Na aula de número 452, em 10 de Dezembro de 1943, Lébeis aborda "O doce nome de você". As anotações em aula sobre esta peça são bastante sucintas, porém na partitura encontra-se a descrição de vários elementos de interpretação usados por ela no estudo da obra, cuja execução seria repetida muitas vezes durante a carreira da cantora e também registrada em gravação feita por ela e Fritz Jank.

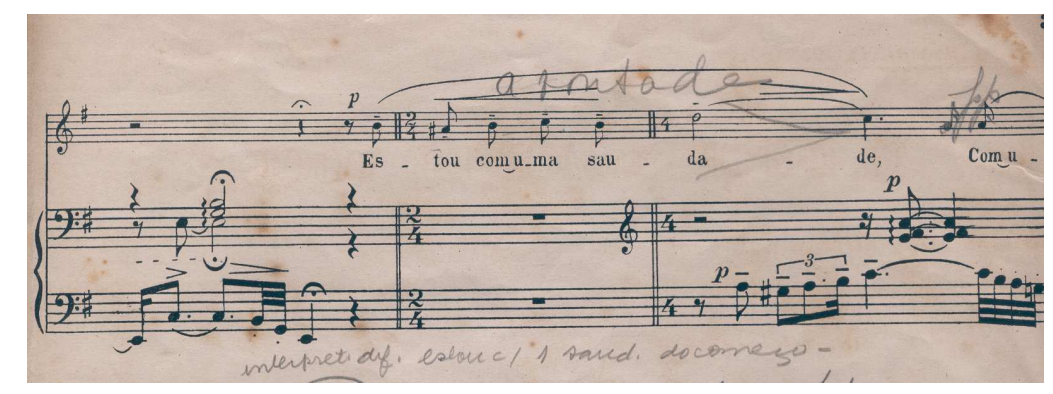

Ex. $16-\mathrm{CML}-572$

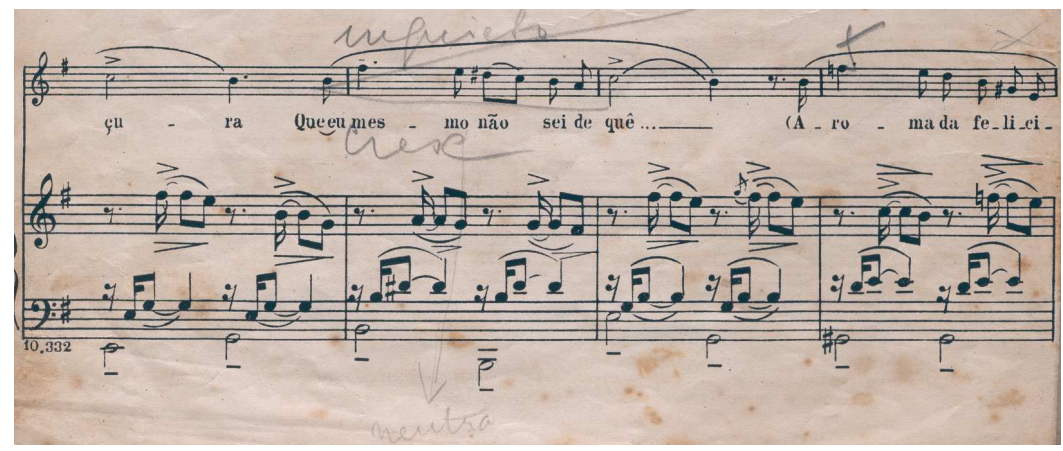

Ex. $17-\mathrm{CML}-572$

Três "estados de espírito" sintetizados em duas palavras e uma expressão ("à vontade", "inquieto" e "ternura") foram as escolhas de Lébeis para representar a emoção e o sentido poético das frases descritas no próximo exemplo e nos dois anteriores. 


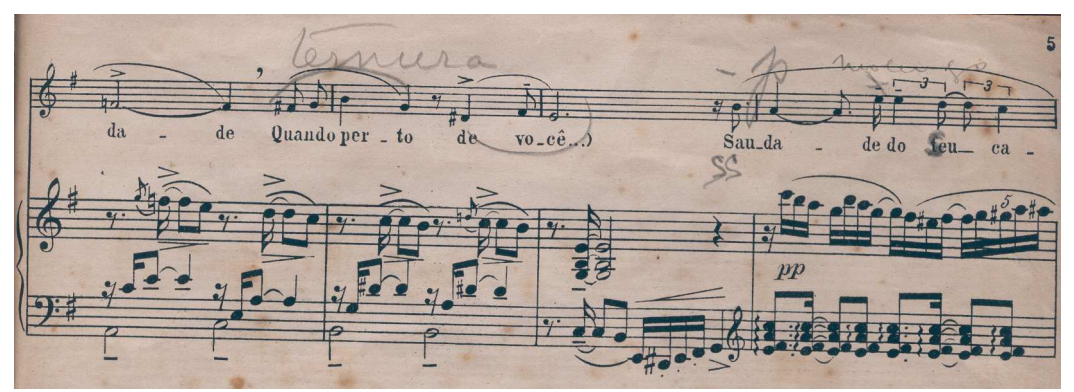

Ex.18 - CML - 572

O destaque para determinados fonemas também é usado nesta obra para enfatizar a palavra em questão ou o seu respectivo sentido. No exemplo anterior se pode notar o destaque dado ao "s" de "saudade", cuja interferência de Lébeis acrescenta dois "ss", o mesmo ocorre com a palavra "sonho". A valorização da consoante "m" na palavra "imensa" da frase "estou com uma saudade imensa de você", parece não deixar dúvidas a respeito da intenção de Lébeis em comunicar aos seus ouvintes que a saudade expressa naquela peça, de fato, era demasiada.

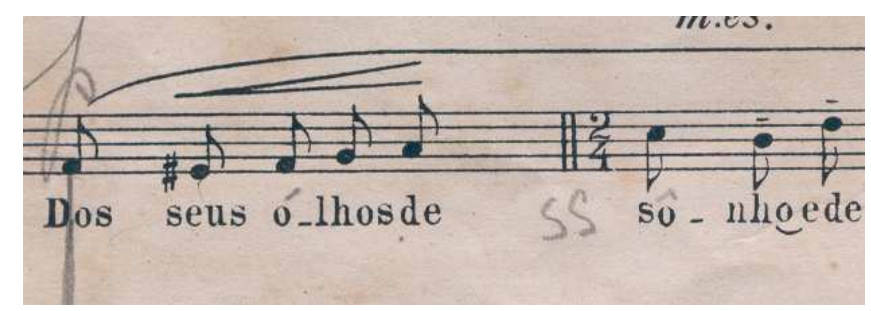

Ex.19- CML -572

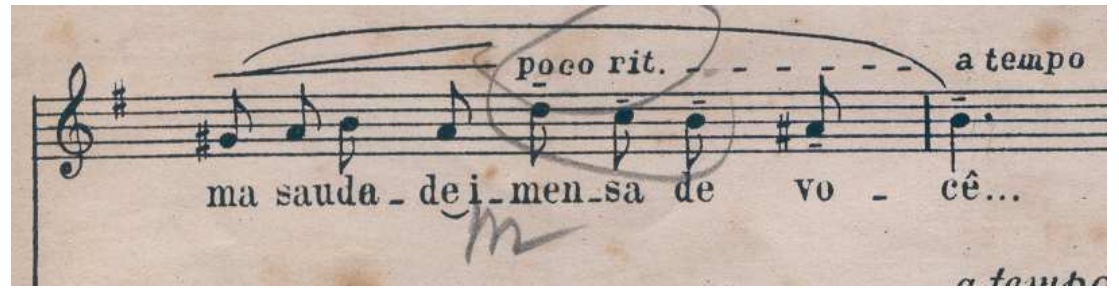

Ex.20 - CML - 572 
Outro recurso de interpretação usado pela cantora foi a readaptação de um trecho do texto em relação a musica. Lébeis identificou um problema de prosódia na obra e propôs uma solução:

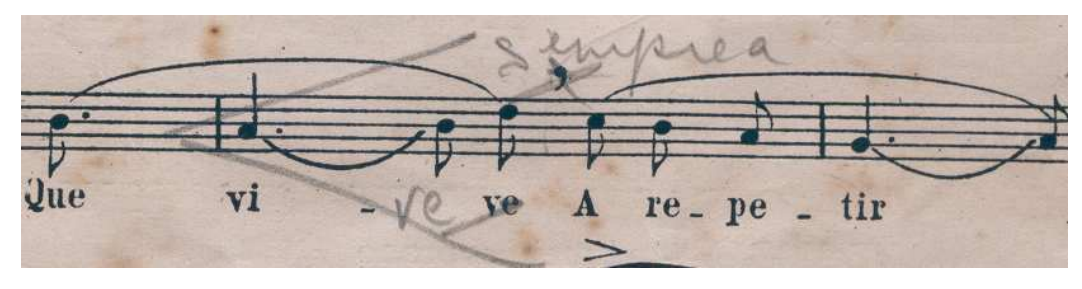

$$
\text { Ex.21 - CML - } 572
$$

Camargo Guarnieri, de quem sempre dei várias primeiras audições compoz [sic] os "Três Poemas de Macunaíma" versos de Mario de Andrade. O segundo, Mandu Sarára, não sendo versos sequentes, resolvi, por conta própria, cantar apenas a primeira e a terceira estrofe. Ao estudar essa belíssima melodia, ao ler "o tatu prepara a cova pra seus dentes desdentados". Embora sendo Mário de Andrade, nessa frase não encontrei poesia e achei que não precisaria cantar esse segundo verso. Expuz meu ponto de vista ao Guarnieri que, na mesma hora, com sua caneta riscou, aceitando meu parecer. - Há em São Paulo um compositor de grande talento: Osvaldo Lacerda. Compoz um punhado de canções que deveria interessar a maioria dos cantores, entre elas está "Ausência". Nessa melodia há um problema na letra e na forma escrita por Lacerda. É nesta frase: "não me deixe então sosinho, não fique longe de mim". Cantada fica "não me deixe-entãol", esse xeitão é horrível! Perguntei ao Osvaldo se eu poderia, sem modificar o sentido, a métrica e a música, cantar: "não me deixe tão sosinha". E minha sugestão foi aceita. (LÉBEIS, 1972, p.10)

A opção do compositor torna o texto menos compreensível à medida que acentua a palavra na sua parte fraca. Lébeis agrega a palavra "sempre" e resolve a questão, como podemos verificar no exemplo anterior.

O uso que Lébeis propõe para a dinâmica nessa obra aparece ligado diretamente a determinadas palavras, de maneira muito consciente para extrair o efeito desejado, associando sentimentos representados pela palavra em questão a uma 
determinada dinâmica musical. Nos exemplos seguintes, "serenidade" e "ternura" são associadas ao "pp" (pianíssimo), enquanto que "enorme saudade" esta associada a uma - enorme - chave de crescendo, ainda mais valorizada pela sugestão "p" que surge logo a seguir.

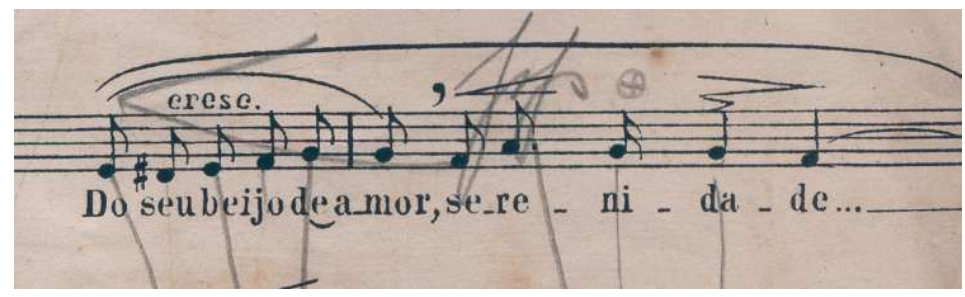

Ex. $22-\mathrm{CML}-572$

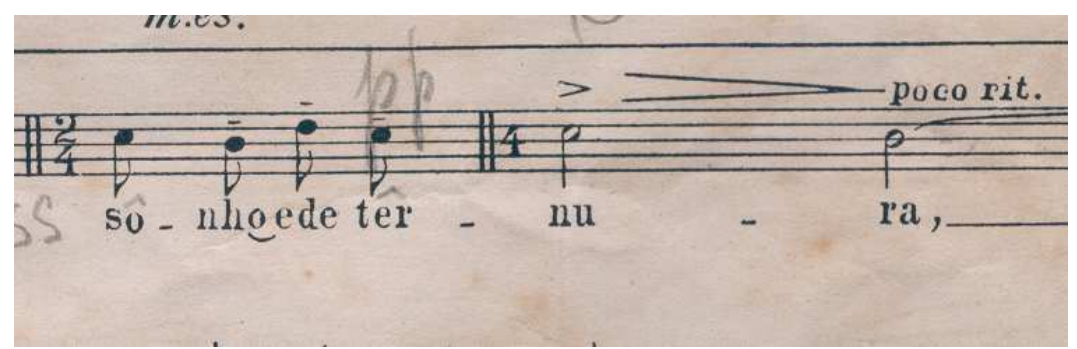

Ex.23 - CML - 572

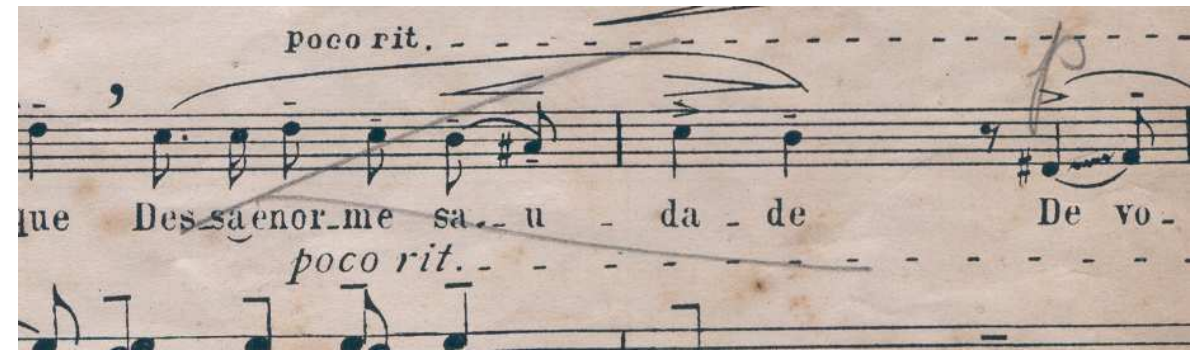

Ex.24 - CML - 572

\subsubsection{CAMARGO GUARNIEIRI, Mozart: A Serra do Rola Moça.}

Poema extraído do "Nocturno de Belo Horizonte" de Mário de Andrade.

"A Serra do Rola-Moça" foi escrita em 1941, dedicada a Jennie Tourel e cantada em primeira audição por Lébeis em 1950, na inauguração do prédio da Sociedade de Cultura Artística. É provável que Verhaalen não tenha tido acesso ao programa desse concerto (incluído no primeiro capítulo do presente trabalho), pois ele afirma que a 
estreia da obra foi no Teatro Municipal de São Paulo. Em verdade, segundo relato de Lébeis, no registro da aula de número 684, lá ocorreu um ensaio com Guarnieri ao piano.

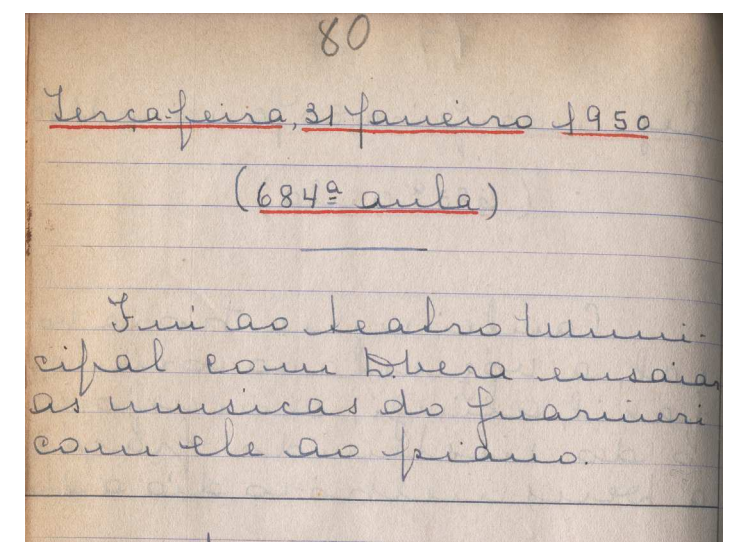

Fig. 26 - Lébeis, quinto caderno de aulas, p. 80.

$\mathrm{Na}$ aula de número 689, Lébeis relata um segundo ensaio, este já no prédio da Sociedade de Cultura Artística.

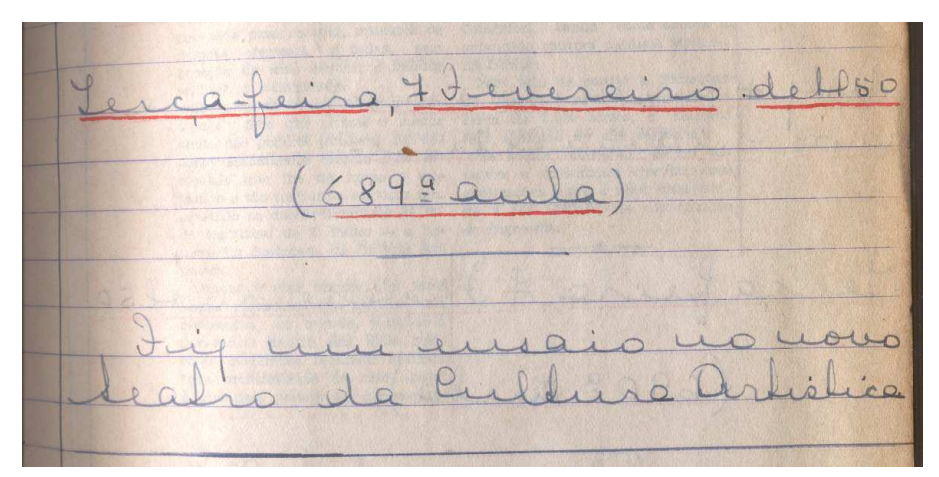

Fig. 27 - Lébeis, quinto caderno de aulas, p. 83.

Verhaalen destaca o caráter narrativo da peça, em analise pormenorizada da obra:

Com o apoio suave do pedal executado por uma única trompa, o canto inicia sua narrativa mixolídia com o refrão: "A Serra do Rola Moça não tinha esse nome, não". As cordas entram gradativamente em surdina, criando um efeito estático que deixa a voz livre para narrar a história dos dois 
amantes que encontraram seu trágico destino no despenhadeiro.

(VERHAALEN, 2001, p. 288)

Janacópulos compreendeu a característica narrativa da obra e orientou Lébeis a esse respeito. Sugere que a peça seja "menos cantada", "mais falada" e usou, segundo Lébeis, a expressão "narrando a história", insistindo no caráter que deveria ter a interpretação, mesmo colocando em segundo plano a beleza da emissão vocal. Cabe ressaltar que tanto Janacópulos quanto Lébeis, por conviverem com Camargo Guarnieri e Mário de Andrade, conheciam muito bem os ideais estéticos dos autores.

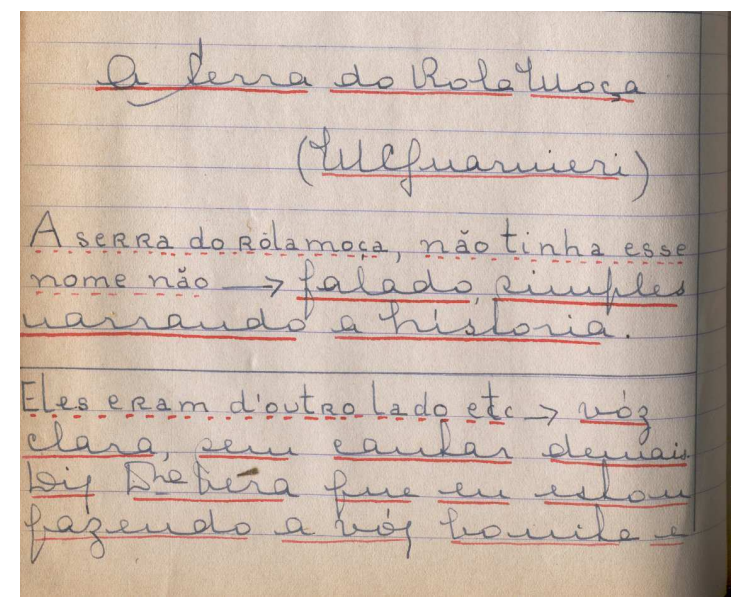

Fig. 28 - Lébeis, quinto caderno de aulas, p. 80.

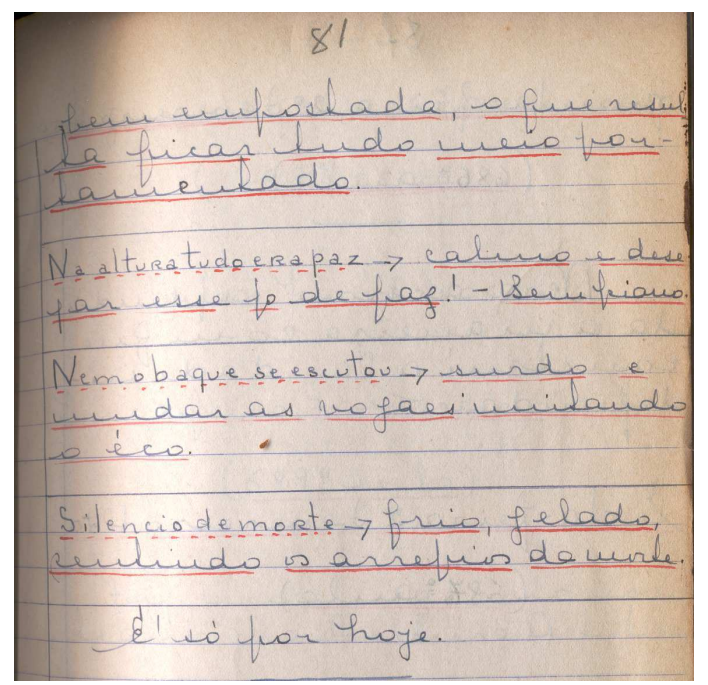

Fig. 29 - Lébeis, quinto caderno de aulas, p. 81. 
No exemplo anterior e nas aulas seguintes, determinações objetivas, tais como abrir mais a boca numa determinada região da voz, mudança de vogal ou o uso da dinâmica, se revesam com as palavras-chave (imagens metafóricas) "arrepiado", "gelado", “calmo", "apreensivo", "fascinado".

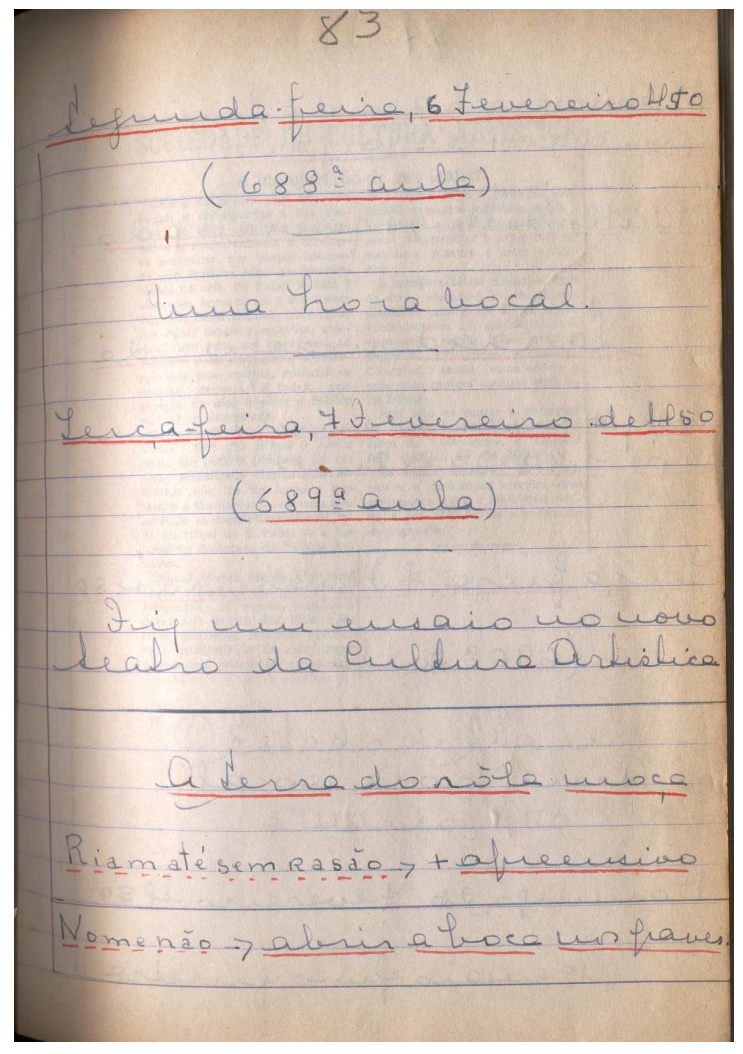

Fig. 30 - Lébeis, quinto caderno de aulas, p. 83.

\subsubsection{VILLA-LOBOS, Heitor: Poema de Itabira.}

\section{Poema de Carlos Drumond de Andrade.}

Os primeiros registros do "Poema de Itabira" nos cadernos de aulas datam de março de 1950, porém Lébeis só viria a apresentar a obra em 1957, regida pelo próprio Villa-Lobos. Em março de 1950, onze dias depois do concerto de inauguração do prédio da Sociedade de Cultura Artística, Lébeis fez a primeira leitura do "Poema de Itabira" com Fritz Jank ao piano. O processo de estudo da obra é relatado primeiramente em 14 aulas (691-704), algumas delas dedicadas exclusivamente à técnica; posteriormente, há também registros dos ensaios da obra com Villa-Lobos. 
O início do estudo do "Poema de Itabira" é marcado, já na segunda aula (692), por um contundente texto de Lébeis, transcrito no primeiro capítulo do presente trabalho, no qual a cantora se revolta diante da postura "hostil a música brasileira" que, teria sido, segundo Lébeis, adotada por Fritz Jank durante a leitura da obra. No mesmo registro, Lébeis pondera sobre a tonalidade da peça: "não poderei cantar na tonalidade em que está escrito porque, desde que é para contalto ${ }^{42}$, a orquestra abafará a minha voz". Na oitava aula desta primeira fase de estudos do "Poema de Itabira" Lébeis registra: "Cantei uma hora acompanhada pelo Salles e dei décor o Itabira, D. Vera encantou-se, graças a Deus."

$\mathrm{Na}$ aula de número 704 , última daquele período de estudos, Lébeis faz um registro bastante detalhado da proposta interpretativa para o "Poema de Itabira". Vejamos a seguir o procedimento adotado e os principais elementos de interpretação:

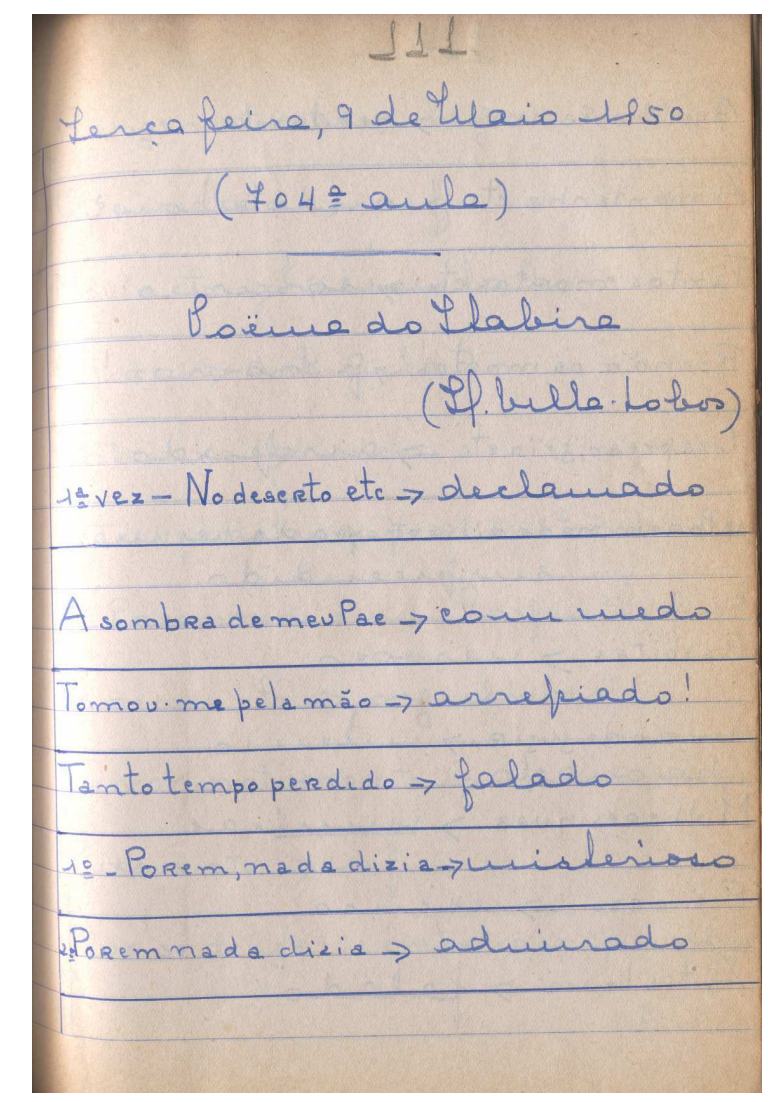

Fig. 31 - Lébeis, quinto caderno de aulas, p. 111.

\footnotetext{
$\overline{42}$ O "Poema de Itabira" foi escrito e dedicado para Marian Anderson, contralto americana.
} 
Desde a aula de número 206, Lébeis apresenta uma mudança no procedimento para registrar os conteúdos, mudança esta que ao longo dos anos vai se tornando mais frequente, ou seja, cada vez mais ela deixa de transcrever nos cadernos trechos das obras em pauta musical, passando a tomar nota prioritariamente do texto da peça e das "palavras-chave" (palavras, expressões, ou pequenas sentenças que representavam para ela o sentimento ou o estado de espírito que deveria manifestar durante a interpretação do trecho em questão). O uso do recurso das "palavras-chave" aparece alternado com determinações bastante objetivas, como a escolha de determinada dinâmica, ou a valorização de algum aspecto da dicção.

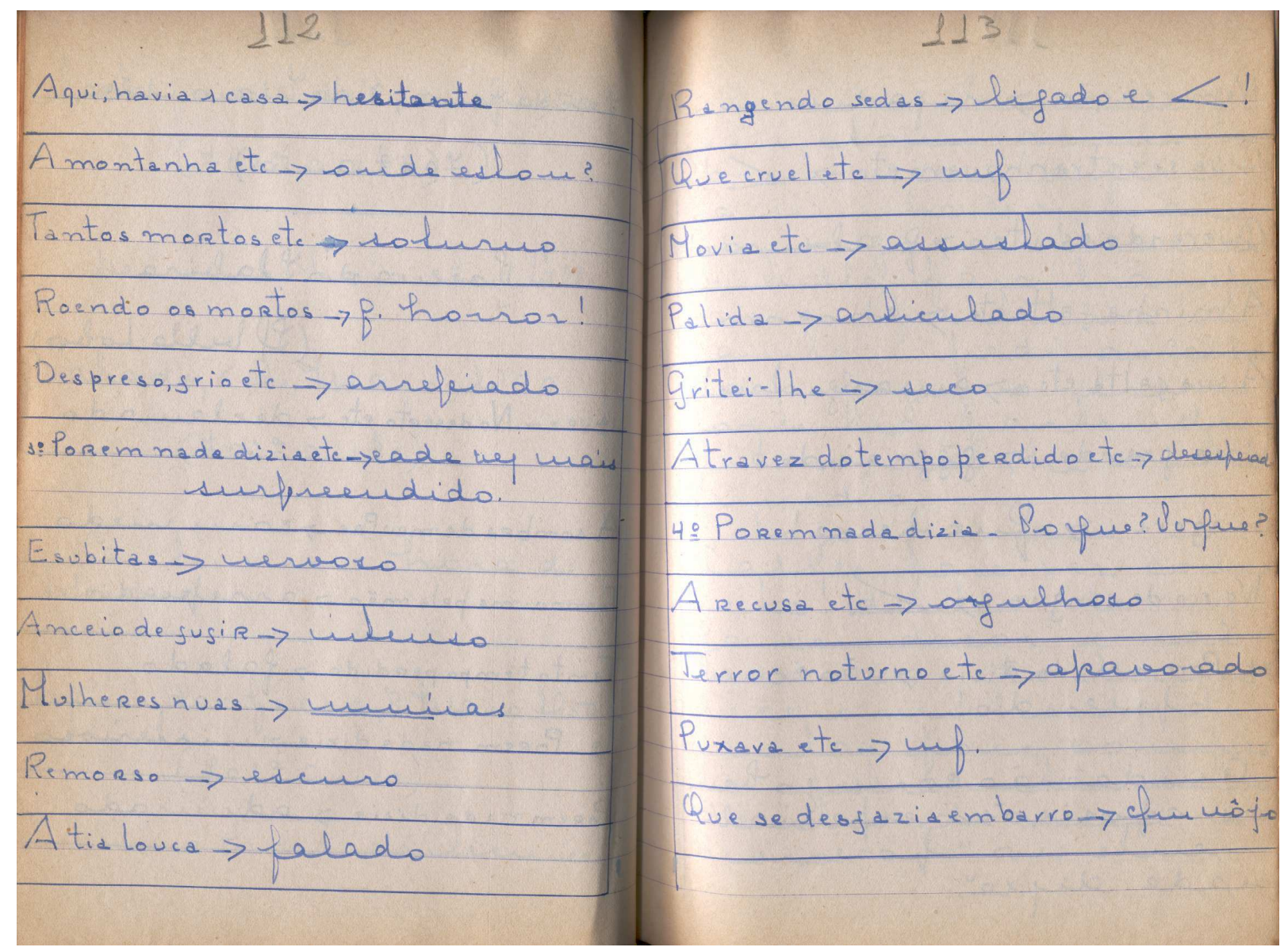

Fig. 32 - Lébeis, quinto caderno de aulas, p. 112, 113. 
Nos dois exemplos anteriores e também na primeira página do exemplo seguinte, podemos observar com clareza a alternância das determinações objetivas com as subjetivas. "Arrepiado", "misterioso", "admirado", "com medo", "hesitante”, "onde estou?", "soturno", "que horror!", “cada vez mais surpreendido”, “nervoso”, "intenso", "assustado", “desesperado", "por que?", “orgulhoso" “apavorado" e "com nojo”, "que absurdo", "choroso", "que pena!", "amargo e triste"; palavras ou expressões usadas para "representar" os sentimentos que guiariam a artista durante a execução da peça e que parecem formar uma espécie de roteiro emocional para a intérprete se alternam com indicações de "crescendo", "ligadíssimo", “declamado", "mf" (meio forte), "articulado", com indicações de destaque para determinadas consoantes: as palavras "nuas" e "grande" aparecem acompanhadas de múltiplos "nnn" e "ggg". Ocorre também uma indicação relativa ao timbre vocal: "escuro".

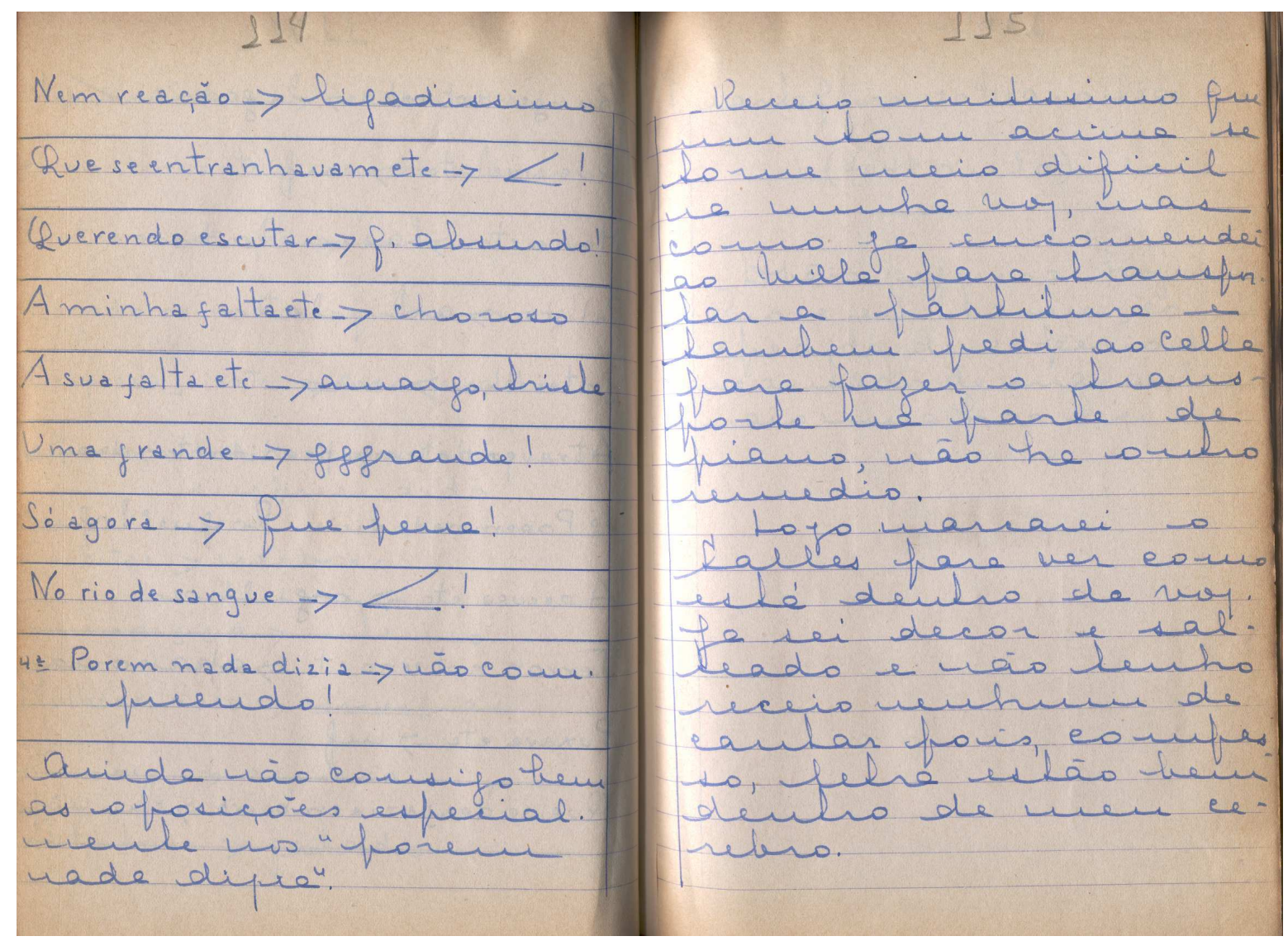

Fig. 33 - Lébeis, quinto caderno de aulas, p. 114, 115. 
A próxima aula de estudos do "Poema de Itabira" foi registrada também sob o número 704, porém em 10 de maio, enquanto que o exemplo anterior era de nove de maio. Lébeis retomou os estudos da obra de 17 a 27 de Junho, quando Janacópulos partiu novamente para o Rio. Encontraremos novos registros sobre essa obra apenas sete anos depois, já nos ensaios para o concerto da peça, sob a regência de VillaLobos, em São Paulo e em Santos.

Quanto à linguagem usada na comunicação dos elementos de interpretação, fica claro que a prioridade de Lébeis e de Janacópulos consistia na compreensão poética e contextual da obra, e, para alcançar este fim, usavam de linguagem híbrida, ou seja, objetiva, como na escolha de determinada articulação ou dinâmica, e, subjetiva e metafórica, por exemplo, com o uso de palavras e expressões tais como, "cantar gostosamente", "extasiado", "com malemolência", "com nojo" ou "com doçura". Lébeis ainda usava, como uma espécie de ferramenta metodológica, as "palavras-chave" (como denominamos), ou seja, palavras ou expressões que simbolisassem a compreensão poética do texto e, portanto guiassem a interpretação. 


\section{CONCLUSÃO}

A atuação como cantoras e educadoras no meio musical nacional, e no caso de Janacópulos, também no cenário musical internacional, foram relevantes, especialmente no tocante a divulgação de obras e de autores nacionais, de obras e de autores do séc. XX e na realização de primeiras audições de obras estrangeiras e nacionais. A técnica vocal e a tradição de interpretação trazida por Janacópulos estabeleceram uma linhagem que se inicia com Lébeis e continua entre seus muitos discípulos.

Também se destacam as participações de Lébeis e Janacópulos em atividades ligadas a Sociedade de Cultura Artística, as Rádios Gazeta, Eldorado, Nacional e Roquete Pinto, ao TBC - Teatro Brasileiro de Comédia, e da EAD - Escola de Arte Dramática da Universidade de São Paulo.

Tanto Janacópulos quanto Lébeis se baseavam primordial e fundamentalmente na compreensão poética da obra, usando uma linguagem híbrida, ou seja, objetiva e subjetiva, quando tratando da interpretação e, procurando se valer de uma linguagem objetiva, baseada na realidade física, quando tratando da comunicação de elementos técnicos. Ambas recorriam à subjetividade de imagens metafóricas na comunicação de elementos da técnica, porém, este recurso não se mostrou prioritário, especialmente no ensino e na comunicação dos elementos específicos - respiração e apoio - submetidos às analises.

Ao analisar os Cadernos de Aulas de Canto de Lébeis, se constata que os procedimentos utilizados por Janacópulos não só eram modernos em seu tempo, como também já se fundamentavam na fisiologia do aparelho vocal para o ensino do conteúdo técnico e valorizavam a compreensão poética na interpretação das obras.

Sem ignorar as mudanças metodológicas que ocorreram nas décadas posteriores à atuação de Janacópulos e Lébeis, podemos dizer que tal maneira de abordar o ensino de canto ainda se reflete na pedagogia vocal, o que percebemos nas considerações teóricas dos autores contemporâneos consultados na elaboração dessa dissertação. 


\section{PERSPECTIVAS PARATRABALHOS FUTUROS}

A multiplicidade de documentos e especialmente a extensão dos registros sistemáticos contidos nos cadernos de aulas de canto, seguramente oferecem elementos para vários trabalhos de pesquisa e suscitam problemáticas de diversas naturezas, tais como as da pedagogia, da história e da performance.

Poderiam ser elaborados trabalhos relacionados à crítica musical publicada em São Paulo dos anos 40 aos 60 (período cujas criticas foram documentadas nos cadernos de aulas), trabalhos relativos a "biblioteca anotada" de Lébeis, além do desenvolvimento de ferramentas analíticas que pudessem auxiliar o trabalho de pesquisa com os registros sistemáticos de Magdalena Lébeis.

Diante da constatação do pioneirismo de Lébeis ao executar obras de compositores brasileiros, foi antecipado um levantamento de todas as aulas descritas nos cadernos, cujo conteúdo tratava de música brasileira. Foi feita uma lista paralela a Bibliografia CML, que destacou apenas as partituras de música brasileira do acervo, que somaram o número de 318 itens do total de 982. Nesta lista ainda foram identificadas as obras autografadas por seus respectivos compositores, as obras dedicadas a Lébeis, as obras feitas em primeira audição e todas as que continham anotações de Lébeis.

Os volumes de número II, III, IV, V e VI dos cadernos de aulas foram transcritos em suas partes textuais, ou seja, sem a transcrição das críticas e dos exemplos em pauta musical. Também foi digitalizado integralmente o documento manuscrito de número 15 da CML - Coleção Magdalena Lébeis, cujo conteúdo trata de questões relacionada ao estudo de canto. 


\section{REFERÊNCIAS}

ÂNGELO, Ivan. 85 Anos de Cultura História da Sociedade de Cultura Artística. São Paulo: Studio Nobel, 1998.

ALDRICH, R. Miss Janacopulos and Mr. Buhlig. The New York Times. New York : NYT, 1919.

ANDRADE, Mário Raul Moraes de. Música e Jornalismo. Prefácio e notas: Paulo Castanha. São Paulo: Hucitec: Edusp, 1993.

CARVALHO, Dinorá de. Noite de São Paulo: phantasia em 3 actos de Alfredo Mesquita. Palavras de Guilherme de Almeida. São Paulo: DEROSA, 1936. Partitura 22 p. Piano com letra.

DIÁRIO POPULAR. Concertos e Recitais. São Paulo, 12 out. 1942.

FRANÇA, Eurico Nogueira. Memórias de Vera Janacópulos. Rio de Janeiro: Ministério da Educação e Cultura, Serviço de Documentação, 1959.

FOLHA DA TARDE. O canto e o talento da suave senhora. São Paulo, 12 fev. 1981. llustrada, p. 32.

GAMA, Mauricio Loureiro. S. Paulo vai ouvir, ainda este mês, uma grande cantora. Diário de São Paulo, 7 maio 1942.

GUERRINI JUNIOR, Irineu. Rádio elite : o papel da Rádio Gazeta no cenário socio cultural de São Paulo dos anos quarenta e cinquenta. Comunicare, São Paulo, v. 6, p. 25-35, 2006.

HECKER, Heloisa Hirai. Alfredo Mesquita Teatro e Crítica na São Paulo de 1940 a 1960. 2009. 94 p. Dissertação (Mestrado em Artes). Universidade Estadual Paulista, São Paulo, 2009.

LAGO, Manoel Aranha Corrêa do. A Música do séc. XX no acervo Vera

Janacópulos/Unirio. In: Revista Brasiliana, Rio de Janeiro, v. 2, maio 1999, p. 2-17.

Brasil. Rio de Janeiro : Reler, 2010.

LÉBEIS, Magdalena. Cadernos de Aulas de Canto (CML Doc. 9) De 30 de out. de 1937 a 13 de jun. de 1939. v. 1, 318 p. Manuscrito não publicado.

Cadernos de Aulas de Canto (CML Doc. 10) De 29 de jul. de

1939 a 21 de ago. de 1941. v. 2, 312 p. Manuscrito não publicado.

Cadernos de Aulas de Canto (CML Doc. 11) De 22 de ago. de

1941 a 11 de jun. de 1943. v. 3, 348 p. Manuscrito não publicado.

Cadernos de Aulas de Canto (CML Doc. 12) De 14 de jun. de

1943 a 30 de jan. de 1948. v. 4, 348 p. Manuscrito não publicado.

Cadernos de Aulas de Canto (CML Doc. 13) De 15 de fev. de

1948 a 14 de ago. de 1954. v. 5, 245 p. Manuscrito não publicado.

Cadernos de Aulas de Canto (CML Doc. 14) De 25 de fev. a 10

de abr. de 1955. (seguido de fotos, programas de concerto, cartas e recortes de jornal até 13 de dez. de 1961) v. 6, 277 p. Manuscrito não publicado.

Efeitos da Dicção Expressiva (CML Doc. 21) Curso de 4 aulas

públicas de Música Brasileira por Magdalena Lébeis. 1972 p. 13-27. Manuscrito não publicado.

(faltam p. 1-4) s. d. 22 p. Manuscrito não publicado. 
Música. Artigo (CML Doc. 23/2) s. d. 2 p. Datiloscrito.

Vera Janacópulos, a artista e a criatura humana. Artigo (CML

Doc. 23/3) s.d. 6 p. Datiloscrito.

LIMA, João de Souza. Moto Perpetuo: a visão poética da vida através da música.

São Paulo: Ibrasa, 1982.

LORENZO FERNANDEZ, Oscar. Toada p'ra você. Poesia de Mário de Andrade. Rio de Janeiro: Mangione, s. d. Partitura 7p. Canto e piano.

MARIZ, Vasco. A canção brasileira de câmara. Rio de Janeiro: Francisco Alves, 2002.

Estúdio, 2002.

A música clássica brasileira. Rio de Janeiro: Andréa Jackobsson

MIGNONE, Francisco. O doce nome de você. São Paulo: Mangione, 1941. Partitura 5 p.

Canto e piano.

MILLER, Richard. La Structure du Chant: pédagogie systématique de l'art du

chant. Paris : La Villette, 1990.

The Structure of Singing: system and art in vocal technique.

New York: Shirmer, 1996.

On the Art of Singing. New York: Oxford University Press, 1996.

PACHECO, Alberto. $O$ canto antigo italiano: uma análise comparativa dos tratados

de canto de Píer Tosi, Giambattista Mancini e Manuel P. R. Garcia. São Paulo: Anna Blume, 2006.

TAVARES, Heckel. Na minha terra tem. Rio de Janeiro: Viera Machado, s.d. Partitura 3 p. Canto e piano.

THE NEW YORK TIMES. Vera Janacopulos sings. New York: NYT, 1919

VERHAALEN, Marion. Camargo Guarnieri expressões de uma vida. Tradução Vera

Silvia Camargo Guarnieri. São Paulo: Universidade de São Paulo/Imprensa Oficial, 2002.

WHITE, Brian. Singing Techniques and Vocal Pedagogy. New York : Garland

Publishing, Inc., 1989. 


\section{BIBLIOGRAFIA}

ALMEIDA, Renato. História da música brasileira. 2. ed.. Rio de Janeiro: Briguiet, 1942.

ANDRADE, Mário Raul Moraes de. Aspectos da música brasileira. São Paulo: Martins Fontes, 1965.

Ensaio sobre a música brasileira. São Paulo: Livraria Martins, 1962. AZEVEDO, Luiz Heitor Corrêa de. 150 anos de música no Brasil. Rio de Janeiro: José Olympio, 1956.

1950.

Música e Músicos do Brasil. São Paulo: Casa do Estudante do Brasil,

BARDIN, Laurence. Análise de Conteúdo. Tradução Luís Antero Reto; Augusto

Pinheiro. Lisboa : Edições 70, 2010.

BRUCHER, N. A.; DODEBEI, V. L. D. L. M. Memória do canto em Vera Janacópulos: análise informacional de partituras. In: XV Semana de debates Científicos, 2003, Rio de Janeiro. XV Semana de debates científicos, Anais., 2003.

CALDEIRA FILHO, João. Aventura da música: subsídios críticos para apreciação musical. São Paulo: Ricordi, 1968.

CAMARGO GUARNIERI, Mozart. A Serra do Rola Moça. Poesia de Mário de Andrade. 1948. Partitura 10 p. Cópia heliografada de manuscrito. Redução canto e piano.

CARVALHO, Olívio da Costa. Dicionário de Francês-Português. Porto: Porto, 1997.

DODEBEI, V. L. D. M. Arquivo Vera Janacópulos: narrativa, mito e informação. In:

GONDAR, Jô; BARRENCHEA, Miguel (Org.). Memória e Espaço: trilhas do

contemporâneo. Rio de Janeiro: 7 Letras, 2001, p. 59-66.

ECO, Humberto. Como se faz uma tese. Tradução Gilson César Cardoso de Souza.

São Paulo, 2006.

LEHMANN, Lili. Meine Gesangskunst. Berlim: ED. BOTE \& G. BOCK, 1922.

LEITE, Edson. Magdalena Tagliaferro: testemunha de seu tempo. São Paulo: Anna

Blume, 2001.

MENEZES, Flo. A acústica musical em palavras e sons. Cotia : Atelier Editorial, 2003 PEPPERCORN, Lisa. Villa-Lobos Biografia ilustrada do mais importante compositor brasileiro. Tradução RODRIGUES, M. T. Rio de Janeiro: Ediouro, 2000. PINHO, Silvia ; PONTES, Paulo. Músculos Intrinsecos da Laringe e Dinâmaica Vocal. Rio de Janeiro : Revinter, 2008.

RAMOS, Eliane Asano. As relações texto-música e o procedimento pianístico em seis canções de Ernest Mahle: propostas interpretativas. In: VOX: IA - Encontro sobre a Expressão Vocal na Performance Musical. São Paulo, 2011, p. 103-115. SILVA, Thaïs Cristófaro. Fonética e Fonologia do Português : roteiro de estudos e guia de exercícios. 10 ed. São Paulo :Contexto, 2010.

SOUZA, Joana Mariz de; ANDRADE E SILVA, Marta Assumpção de; FERREIRA, Léslie Piccolotto. $O$ uso de metáforas como recurso didático no ensino de canto:

diferentes abordagens. In: Revista da Sociedade Brasileira de Fonoaudiologia, v. 15, n. 3, p. 317-328, 2010.

SOUZA, Joana Mariz de. Pedagogia Vocal Moderna e ciências da voz: interação e conceitos comuns. In: VOX - Encontro sobre a Expressão Vocal na Performance Musical. São Paulo, 2011, p. 167-177. 
ULBANERE, Alexandre. Willi Corrêa: por um ouvir materialista histórico.

Dissertação (Mestrado em música). Universidade Estadual Paulista, São Paulo, 2005.

VILLA-LOBOS, Heitor. Poema de Itabira. Poesia de Carlos Drumond de Andrade. Paris:

Max Eschig, 1956. Partitura 18 p. Redução canto e piano.

- Poema de Itabira. Poesia de Carlos Drumond de Andrade.

Partitura (um tom acima do original) 20 p. Manuscrito. 
ANEXO I 
CADERNO DE AULAS DE CANTO

(vol. 1) 


\section{Sábado, 30 de Outubro de 1937}

\section{$\left(1^{\mathrm{a}}\right.$ aula $)$}

Tive hoje uma das mais belas impressões de minha vida. Pareceu-me estar sonhando tal o meu deslumbramento tendo a primeira lição com Dona Vera Janacópulos! Antes de tudo: ela sabe ensinar, sabe demonstrar, com inteligência e capacidade os pequeninos detalhes da arte do canto. Não basta ser artista para lecionar pois, isso é um dom. Com que clareza Dona Vera transmite aos alunos! Ela fez primeiro um esboço da qualidade do som. Fez uma verdadeira conferência anatômica. Perguntou-me se eu tinha para cantar alguma maneira de respirar diferente da que uso para falar Respondi-lhe que não havia reparado que eu apenas já sabia calculá-la afim de não acabar um trecho sem fôlego. Em seguida continuou:"nós devemos respirar normalmente sentindo estufar os lados, alargamento do tórax. Não encher por completo os pulmões de ar, pois quando os enchemos em demasia, a qualidade do som não sai redonda devido ao excesso de ar. Devemos conservar a boca sempre redonda, como se tivéssemos, dentro dela, uma massa dura de gesso que nos impedisse de fechá-la . A cabeça, os ossos do rosto, os ouvidos são a nossa caixa de ressonância, assim como o violino, o violoncelo têm em suas caixas uns furinhos pelos quais saem os sons. Si cantarmos com a boca pouco aberta e com a língua para cima, o som não poderá sair claro e redondo, sai duro e estridente. É curioso fazer esta experiência numa só nota: deu um fá agudo com a boca meio cerrada, saiu estridente, depois, na mesma respiração sobre a mesma nota arredondou a boca alargando o tórax com elasticidade tornado o som aveludado e sonoro. A língua deve estar sempre pousada no soalho da boca. Todas as vogais são cantadas da mesma forma. Nas vogais e i, não é preciso adaptar aquele "sorriso" que me viciou. Nada de contrações. Deu-me para vocalizar na hora da lição um exercício. Aconselhou-me a ainda não estudar sozinha. O exercício é o seguinte:

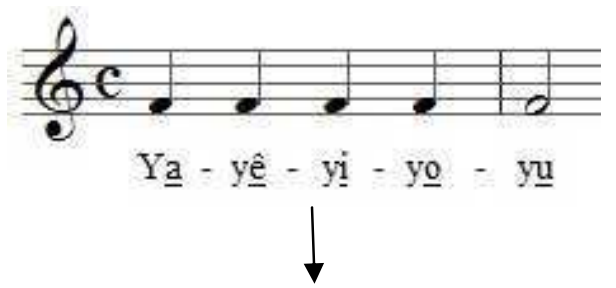

começar em mi ou fá, chegar mais ou menos ao ré ou mi agudo.

Pediu-me para respirar da seguinte forma: nunca deixar que os outros ouçam a minha respiração. Quando encher o pulmão seguir logo com a nota passando de uma vogal para outra suavemente. Procurar sempre arredondar a boca nas vogais e i.

Tenho em seguida uma figura tirada do livro de Lilli Lehmann que é justamente o que Dona Vera explica. 


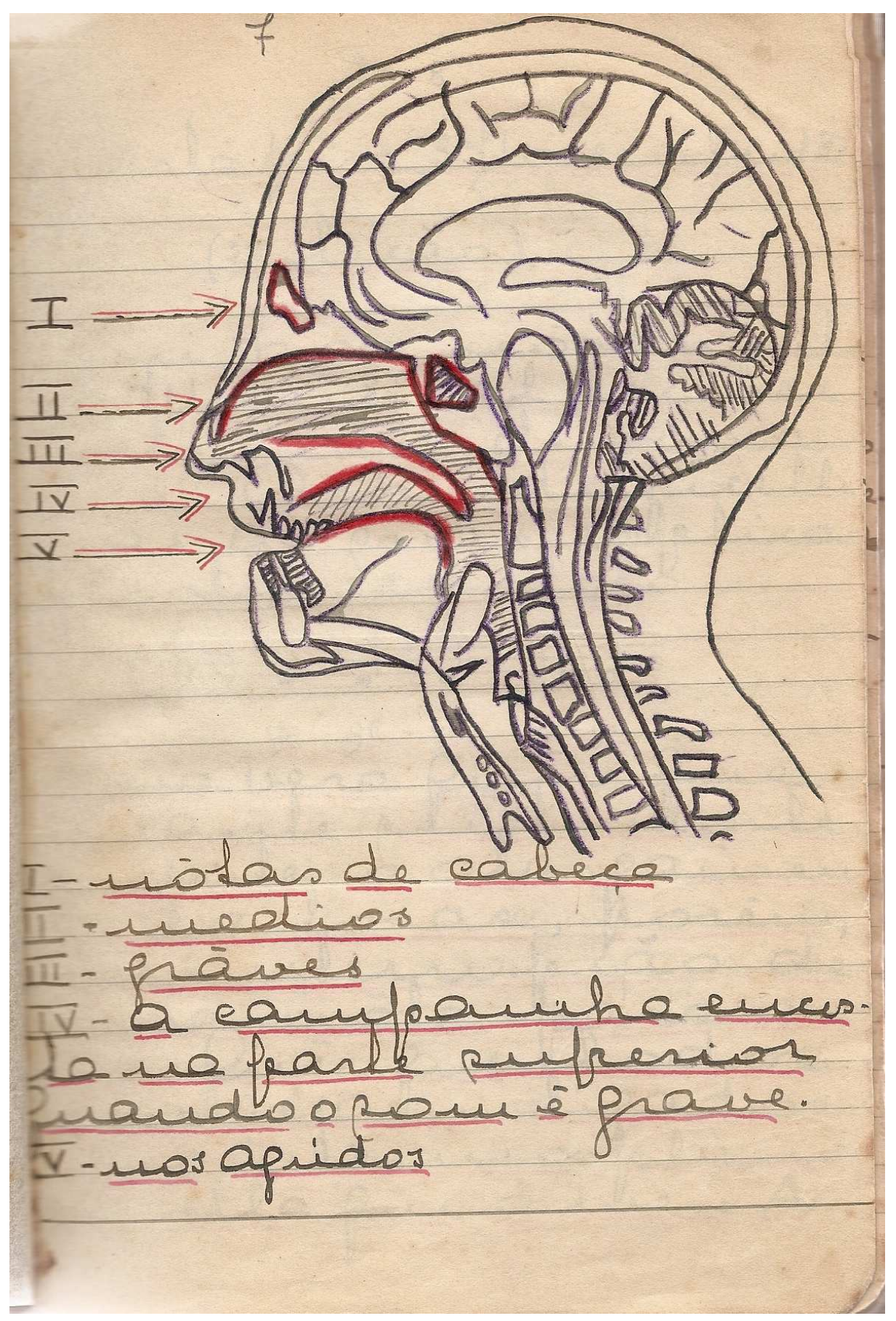

97 


\section{Quarta-feira, 3 de Novembro de 1937}

( $2^{\mathrm{a}}$ lição)

Fui hoje novamente ao Municipal receber outra aula de Dona Vera. Achei dificílimas as suas explicações. No exercício:

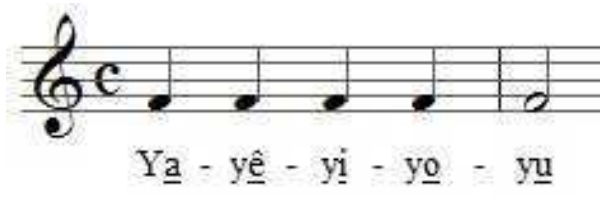

Dona Vera quer que se cante sentindo levemente o alargamento do tórax, porém, sem interrupção de uma nota para outra. Quer que todos os sons sejam ligados e no mesmo plano. Diz ela que o meu A é bom, mas que o $\mathrm{E}, \mathrm{I}, \mathrm{O}, \mathrm{OU}$, faltam arredondar mais os sons. Amanhã começarei a estudar um pouco sozinha. Preciso estudar diante do espelho, dando apenas uns acordes ao piano, com um lápis afastando o queixo impedindo que ele vá para frente. Passou-me outro exercício que também não é fácil. Fazer uma terça (Do Mi) sendo as duas primeiras notas de boca fechada sentindo as vibrações dos maxilares e do nariz. E, apesar da boca fechada, sentindo arredondada por dentro, com o véu palatino suspenso como se eu fosse dizer "Mou". A $2^{a}$ terça de boca aberta terça dizendo o com a mesma altura e igual sonoridade.

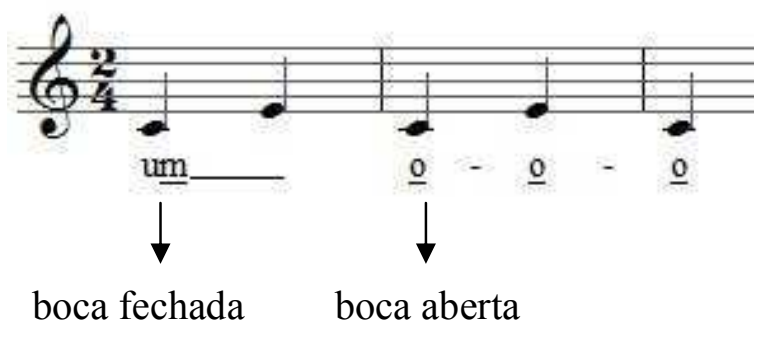

Estou achando muito complicado. Sinto que minha voz não sai. Acho dificuldade em tudo, nos agudo as, nos médios (que não têm timbre), nos meus graves que são de peito.

\section{Quinta-feira, 4 de Novembro de 37}

Experimentei hoje pela primeira vez a estudar sozinha, cantei apenas minutos. Verifiquei com prazer que compreendi um pouco as explicações dadas por Dona Vera. 


\section{Sexta-feira, 5 de Novembro de 1937}

$\left(3^{\mathrm{a}}\right.$ aula $)$

Dei hoje mais uma aula. Senti-me desanimada pois ainda não pude perceber bem o arredondamento do som como Dona Vera quer. Tive inegavelmente uma má escola pois, o pouco que aprendi, aprendi sem base de espécie alguma.

Sábado, 6 de Novembro de 1937

$\left(4^{\mathrm{a}}\right.$ aula $)$

Eu estava certa de não emitir bem a voz e certa de que não havia entendido, no entanto, não fui de todo mal. Tenho tendência de, nas vogais e, i], fazer o queixo ir para frente. Devo estudar com um lápis na boca. Devo dizer estas vogais, com as narinas abertas. No exercício que segue:

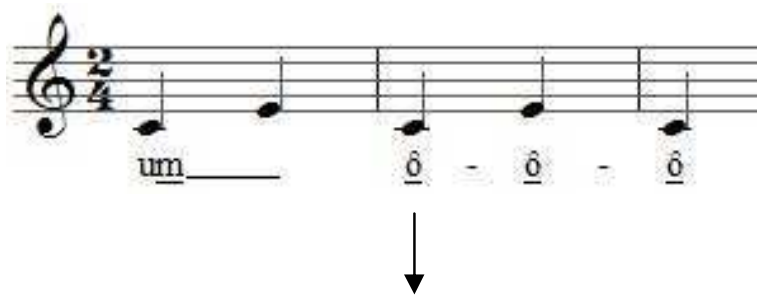

Estou fazendo de garganta, prova é que quando faço a segunda terça eu não consigo emitir a mesma sonoridade. Devo emitir ambas com igual altura, sendo que na primeira devo sentir bem as vibrações dos maxilares e devo cantar de boca fechada. A outra terça dizer em [o], mexendo um pouco com a língua, e com o pescoço para desmanchar alguma contração.

Como se constitui a respiração:

I - No mesmo tempo que se respira o diafragma vai se estendendo.

II - alarga-se o tórax com o apoio

III - Assim constitui o armazenamento da respiração.

IV - Significa a pressão da respiração contra os músculos do peito, ou por outra, contra os músculos de "resistência" do peito. 


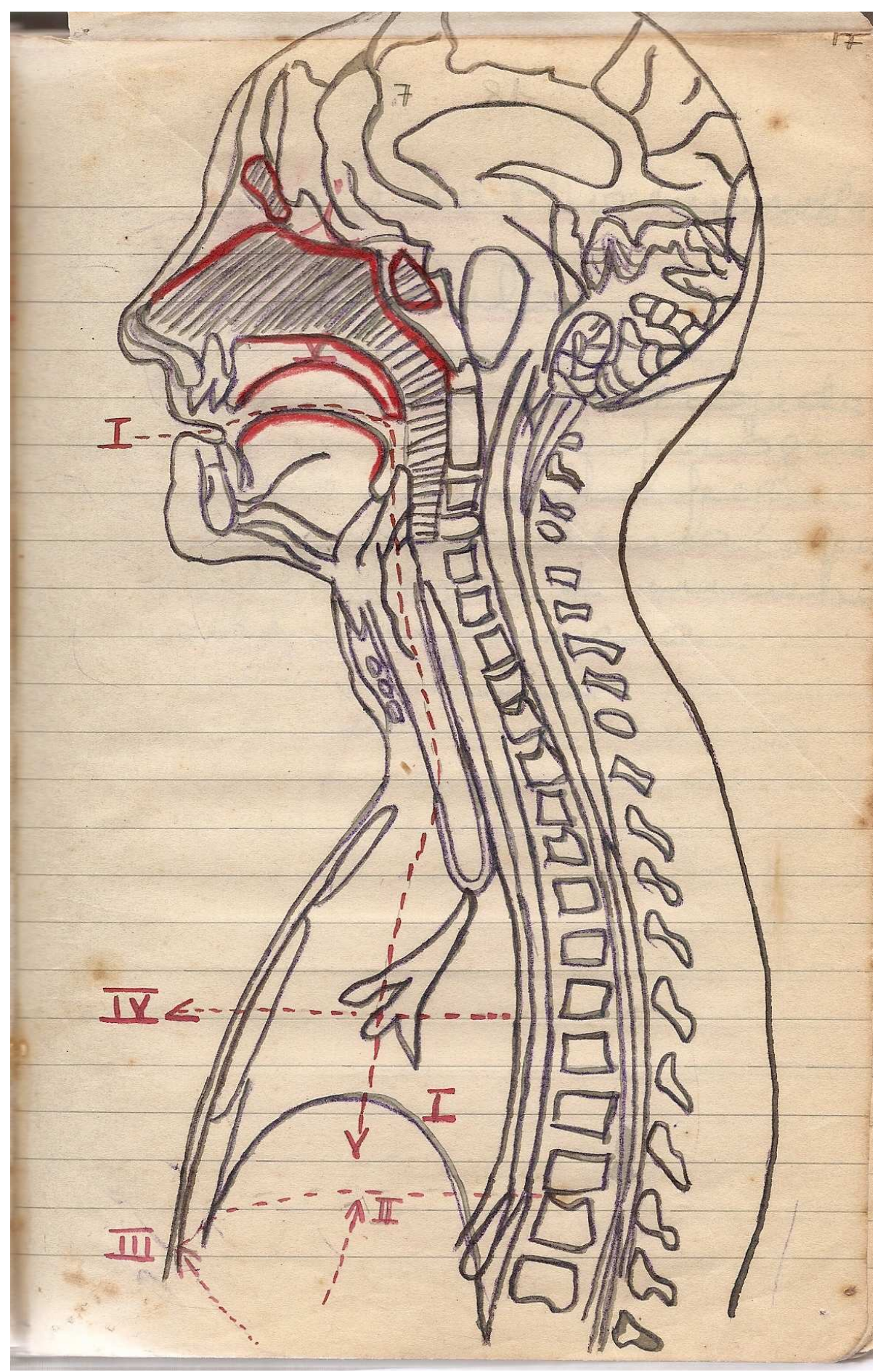


Segunda-feira, 8 de Novembro de 1937

$\left(5^{\mathrm{a}}\right.$ aula $)$

Na lição de hoje demonstrei um progressosinho muito pequeno, pequeno demais para satisfazer à minha grande exigência.

\section{Quarta-feira, 10 de Novembro de 1937}

(6 aula)

Aprendi hoje um novo exercício que é o seguinte:

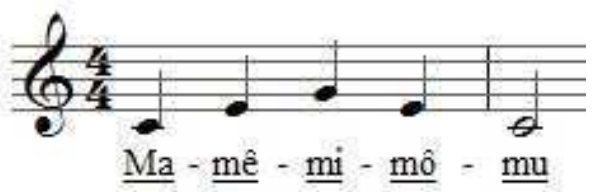

Comecei também com uma bergerette "que me suis-je la fougère" de Pergolesi.

\section{Quinta-feira, 11 de Novembro de 1937}

(7 aula)

Preciso prestar muita atenção no exercício que esta na página anterior. (ma-me-mi-moum) a sonoridade do mi está estridente, preciso arredondar mais a boca e sentir o queixo bem para traz. Na bergerrette, não ouvir a respiração.

Que je suis-je la fougère

(1710 - 1736) (Pergolesi)

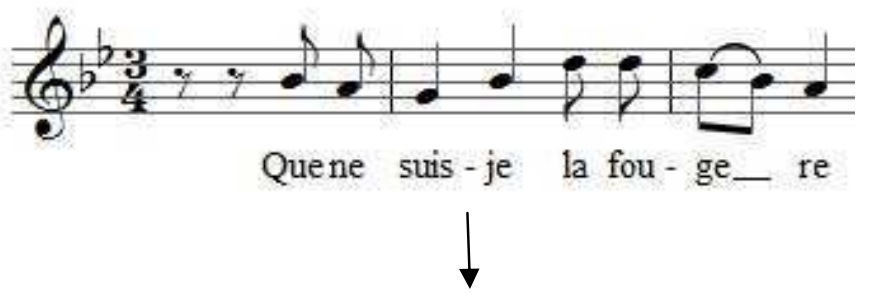

pouco sopro e muito plano 

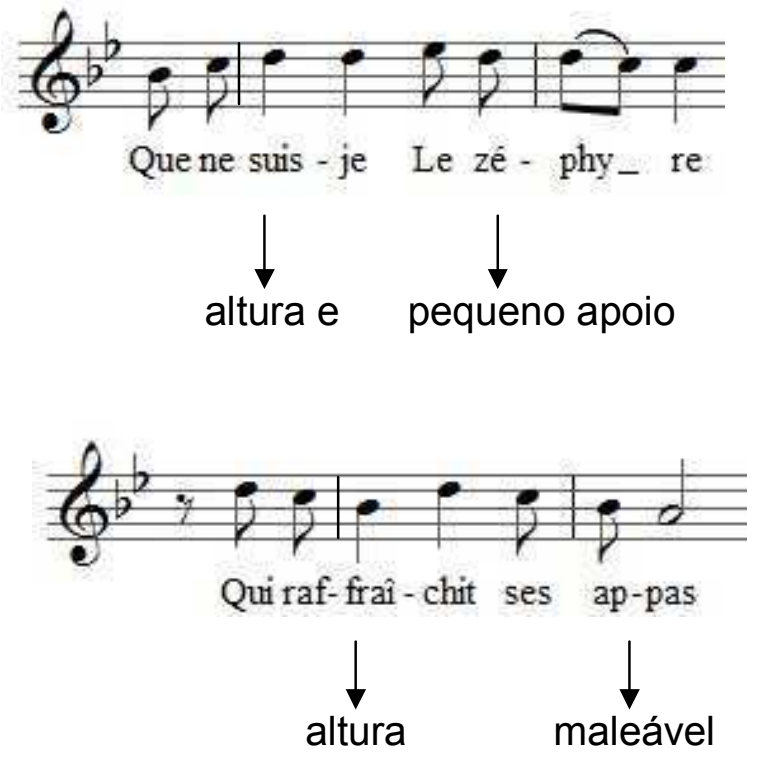

Dona Vera aconselhou-me a estudar dizendo, sobre uma nota só (ex. do-do-do-do, etc) a letra dessa bergerette.

\section{Terça-feira, 16 de Novembro de 1937}

(8 aula)

As explicações de Dona Vera cada vez me estão sendo mais luminosas. No exercício (ma,me, mi, mo, mu) melhorei. Passou-me um novo.

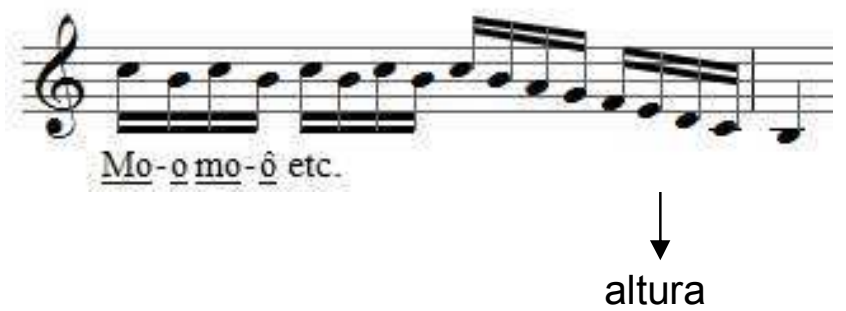

Para se preparar este exercício deve-se dizer primeiro, sem cantar, bastante vezes "mo-yo-mo" com o queixo mole e bem nasal.

$\mathrm{Na}$ bergerette, Dona Vera acha que eu faço esforço. Preciso ter todas as notas colocadas no mesmo plano, na altura de i com a boca arredondada. Tive hoje algumas explicações sobre o "Nel cor più non mi sento" de Paisiello. 
Nel cor più non mi sento

(1741 - 1816) (Paisiello)

Preciso prestar atenção para fazer as colcheias mais leves.

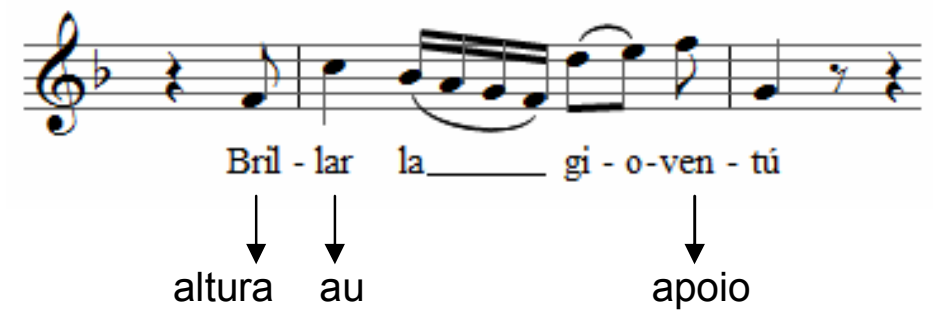

Domingo, 20 de Novembro de 1937

(9a aula)

Dona Vera deu-me hoje uma explicação da colocação das vogais na boca para que todas elas fiquem claras, bem emitidas e naturais.

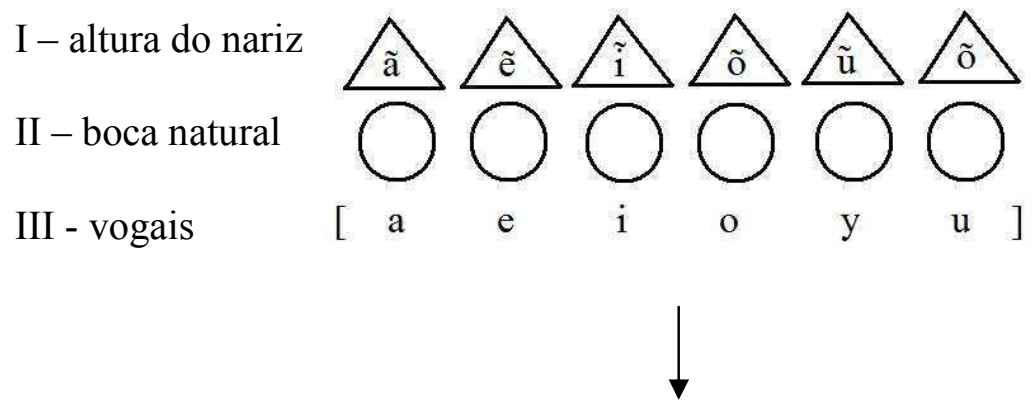

Para todas as vogais manter a boca redonda como o numero II. O numero I indica o seguinte: quando a vogal é a, deve dizer, com a boca redonda, sentindo no nariz au para não ficar o som rachado por ex: brillar, não se deve dizer brillar e sim como se fosse brilaur, não anasalado demais, apenas com muita altura para o som ser redondo e timbrado. 
Terça-feira, 22 de Novembro de 1937

(10 aula)

Estou cada vez mais encantada com as lições de Dona Vera. Tenho melhorado um pouco especialmente nos graves e agudos. Os agudos não estão tão bem, atinjo o sol com uma certa dificuldade. Tenho que estudar os seguintes exercícios:

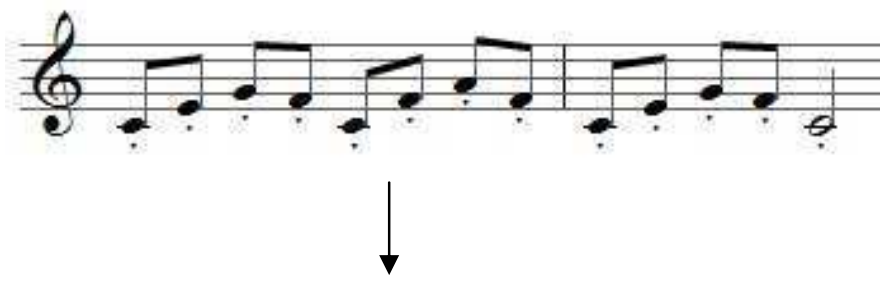

Em u bem piqué, piano sonoro, sentindo levantar as orelhas, narinas abertas e bem de cabeça. Nota de cabeça quer dizer nota sem apoio.

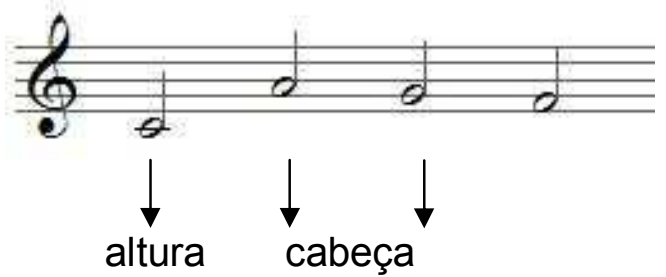

Sentir as narinas abertas com a mesma intensidade de sopro como se as notas saíssem pelos olhos. Dona Vera quer que todos os exercícios sejam cantados com ritmo para que se aprenda a equilibrar e a calcular a respiração.

No exercício que segue a primeira oitava é forte e com apoio, a segunda bem de cabeça mas, sem portamento como se fosse o-yu.

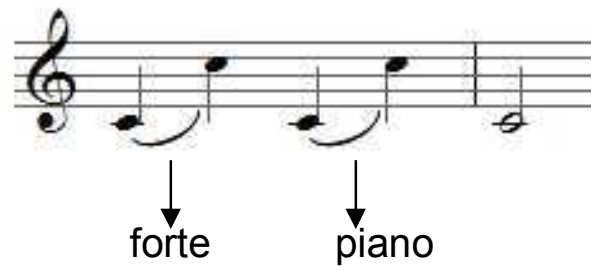

\section{Quinta-feira, 25 de Novembro 1937}

$\left(11^{\mathrm{a}}\right.$ aula $)$

Estou desanimada com o meu estudo. No exercício de nota de cabeça, sinto que meus lábios tremem isso é devido a alguma contração que preciso desmanchar, talvez sentindo a língua mais tranqüila e bem pousada. 
Sábado, 27 de Novembro de 1937

(12 aula)

Consegui melhorar um pouquinho. Aquele pigarro que me encobria a voz hoje não senti mais. Fiz um novo exercício:

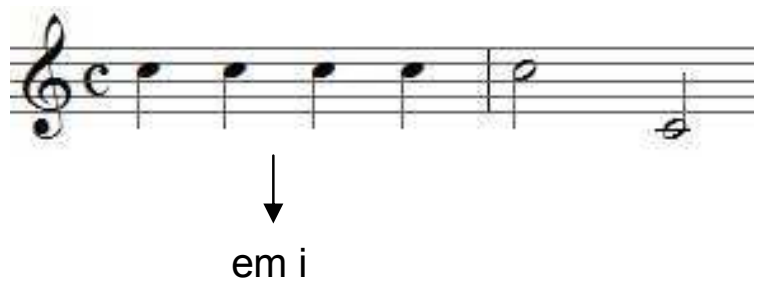

Sentir em cada nota o alargamento do tórax. Começar a primeira nota de cabeça, com muita altura, de cima para baixo, e fazer o grave na mesma altura e não fechar a boca para não esmagar o som, não fazer portamento.

\section{Segunda-feira, 29 de Novembro de 1937}

(não fui à aula)

Quinta-feira, 2 de Dezembro de 1937

(não fui à aula)

Quinta-feira, 2 de Dezembro de 1937

$\left(13^{\mathrm{a}}\right.$ aula)

Dona Vera achou em mim uma grande diferença. Os exercícios foram melhores. Uma boa maneira de estudar o exercício (mo-o-mo) é fazer em nhi.

Nel cor piu nom mi sento

(1741 - 1816) (Paisiello)

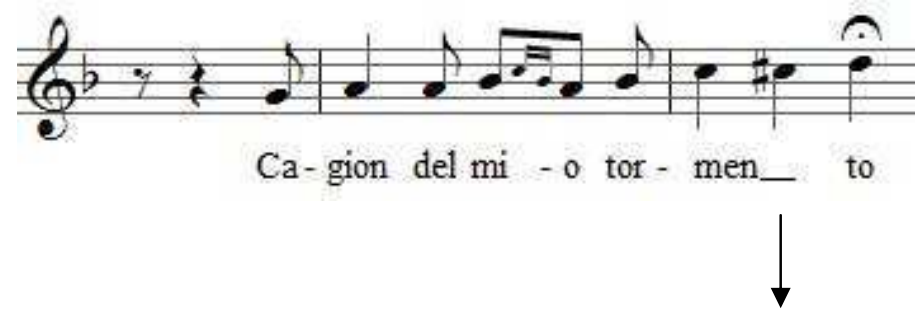

pouco sopro no do sustenido 


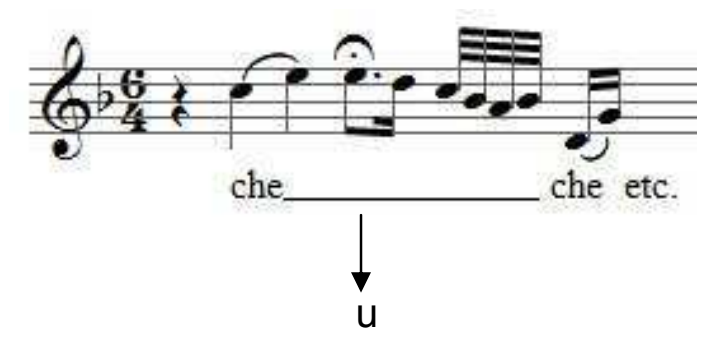

Segunda-feira, 6 de Dezembro de 1937

$\left(14^{\mathrm{a}}\right.$ aula $)$

Dei uma lição péssima, mas... não foi minha culpa, estava meio indisposta. Aprendi hoje um novo exercício.

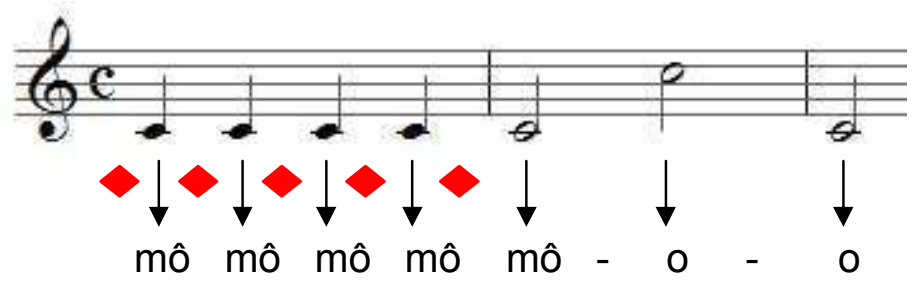

Esses sinais vermelhos indicam que para dizer o mo alto e redondo di-se antes de boca fechada $m$ depois mo. Deve-se fazer rápido a preparação para a oitava, não fazer piano a nota de baixo para que a aguda não fique com excesso de sopro. Respira-se depois do quarto do.

Li um livro "École de Garcia do qual tomei nota do seguinte:

La seule maniere de respirer

Le pommons s'apuiente sur le diaphragme, qui le sépare tout à fait de l'abdomen et son en autre enveloppés par les côtes. Leur developpement, au moment de l'inspiration, peut se faire à la fois de haut en bas par la contraction du diaphragme et lateralement par l'ecartement des côtes. L'intensité du son dépend de la quantité d'air qui fait explosion vive à la fois. Le por de voix aidera à egalises les registres, les timbres et la force de la voix. Dans les ports de voix ascendants, ou evitera avec coin d"avoir la voyelle; il vaut presque mieux la couvrir legèrement. II faut se garder surtout d'attaquer loes sons avec un port de voix inferieur. Ce défaut est donnant en france.

\section{Sábado, 10 (seria 11) de Dezembro de 1937}

(15 aula)

As vocalizes foram bem. Dei hoje pela primeira vez "Comme raggio di sol" de Antonio Caldara cujas explicações ainda nada posso anotar. Resolvi hoje despejar a voz sem timidez e deu resultado. 
Segunda-feira, 13 de Dezembro 1937

(16 aula)

Melhorei nos graves e nos sons de boca fechada.

Comme raggio di sol

(1670 - 1736) (Caldara)
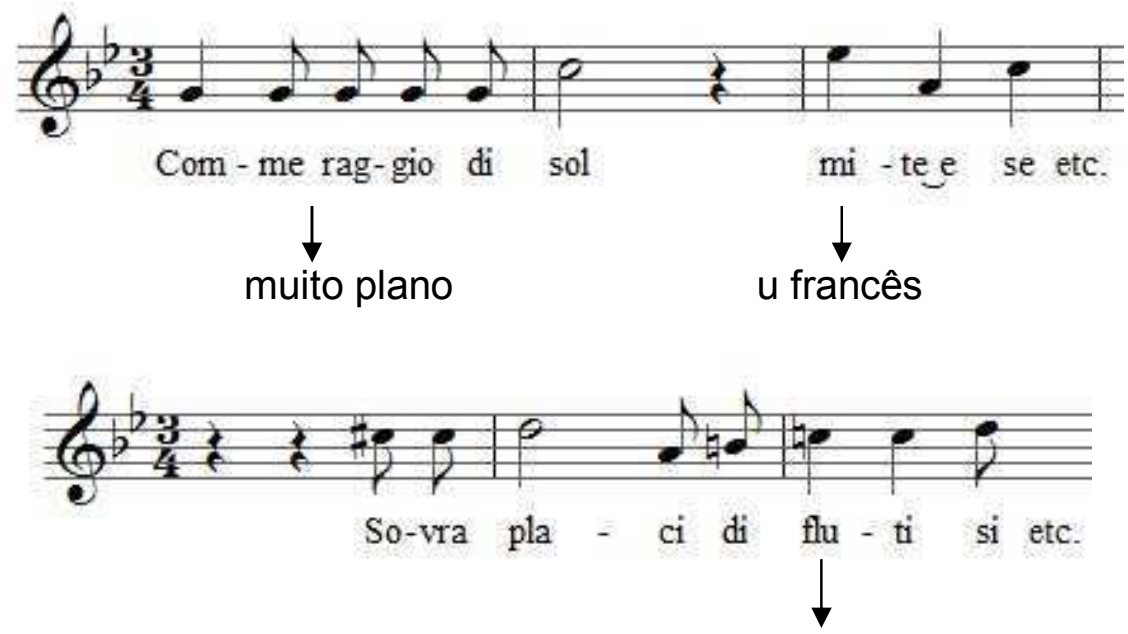

fazer claros os acentos tônicos
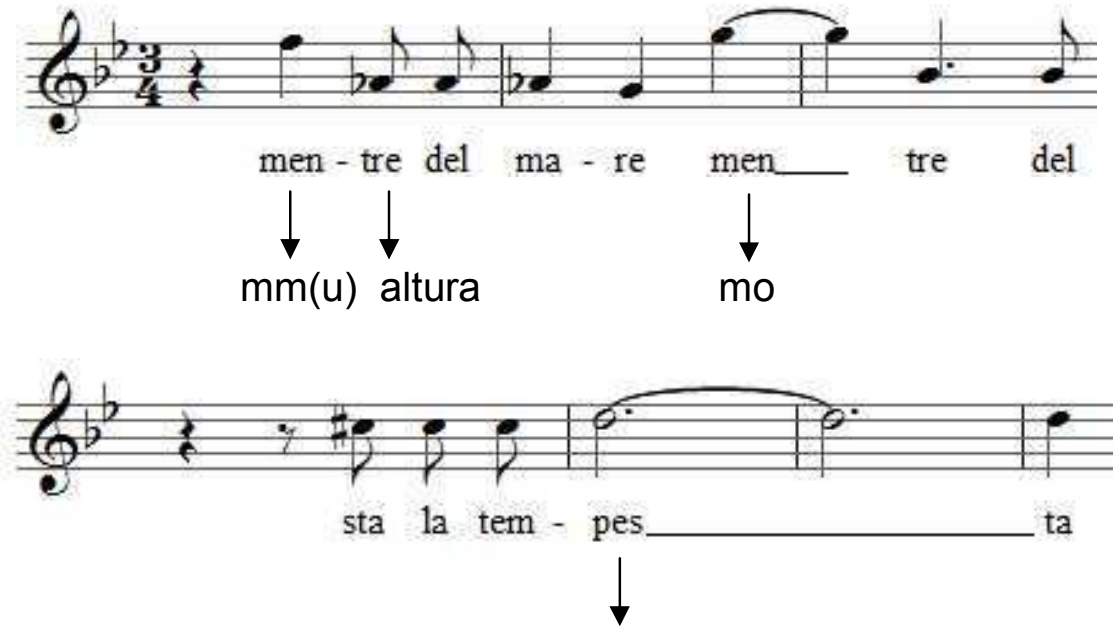

mudar as vogais e-o-u fazer o crescendo da nota com o alargamento do tórax, apoio, muita maleabilidade, muita altura, queixo mole e narinas abertas. 


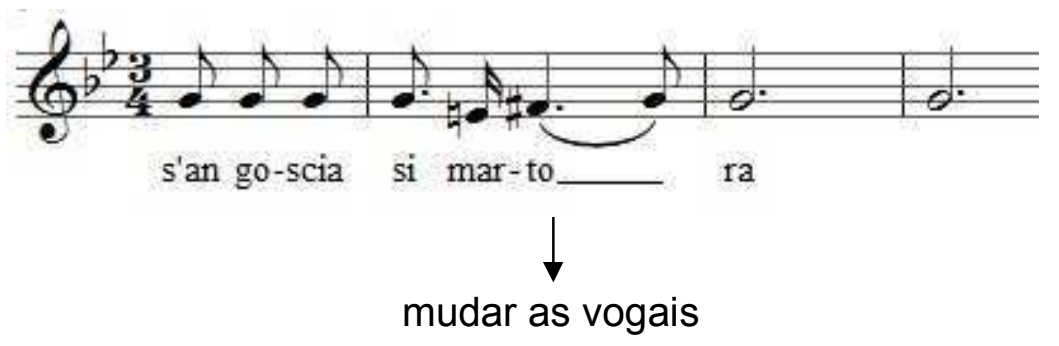

Quinta-feira, 16 de Dezembro de 1937

$\left(17^{\mathrm{a}}\right.$ aula)

A lição correu relativamente bem. Dona Vera me fez cantar a escala de Lili Lehmann com as palavras de "Comme raggio di sol".

"Comme raggio di sol"

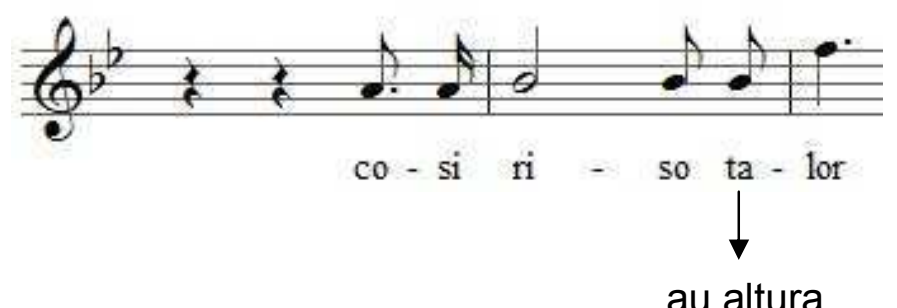

au altura

Devo estudar esta frase em vários tons.

Segunda-feira, 20 de Dezembro de 1937

(18 aula)

A minha lição foi bastante boa. Dona Vera notou progresso no exercício "piqué" e na escala de Lili Lehmann, achou grandes melhoras na emissão, na altura, na abertura da boca em o e no queixo mole. A música também melhorou.

\section{Quarta-feira, 29 de Dezembro de 1937}

(19a aula)

Fui ao teatro municipal para matar as saudades destas aulas que enfeitam tanto a minha vida. Graças a Deus estou melhorando mas... a passo lento. "Comme raggio di sol" está quase bem, os agudos estão melhorando consideravelmente. 
Quinta-feira, 30 de Dezembro de 1937

(20a aula)

Foi pena eu hoje precisar voltar mais cedo pois, se possível me fosse eu passaria o dia todo ouvindo Dona Vera lecionar minhas colegas. Cada explicação sua é uma luz que fica para toda a vida! Na vocalize de hoje eu atingi o lá bemol. 
1938 
Quarta-feira, 05 de Janeiro de 1938

$\left(21^{\mathrm{a}}\right.$ aula)

Comecei hoje com um exercício novo que é o seguinte:

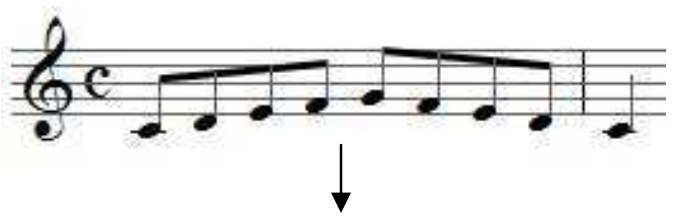

dizer i com muita altura

"Sento nel core"

Scarlatti $(1659+1725)$
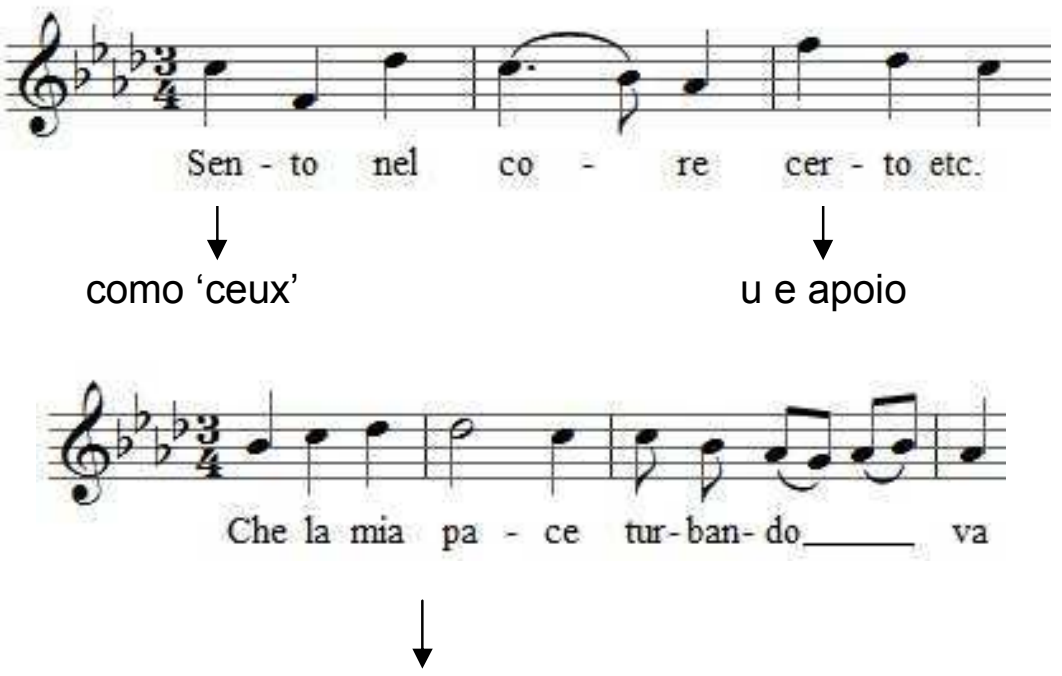

dizer mía e não mia

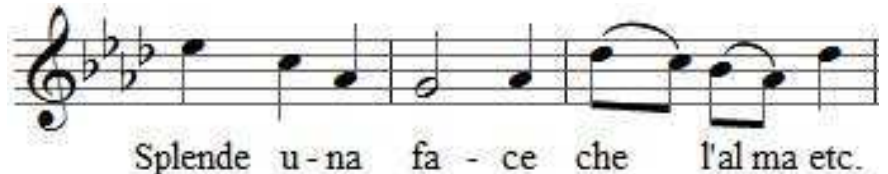

$\downarrow$

como se fosse dizer oeuf, boeuf com a boca em o 


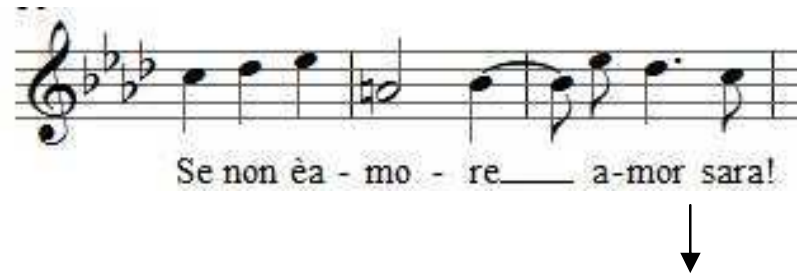

com altura e bocejada

\section{Segunda-feira, 10 de Janeiro de 1938}

$\left(22^{\mathrm{a}}\right.$ aula)

Este exercício que hoje dei preciso fazer da seguinte forma:

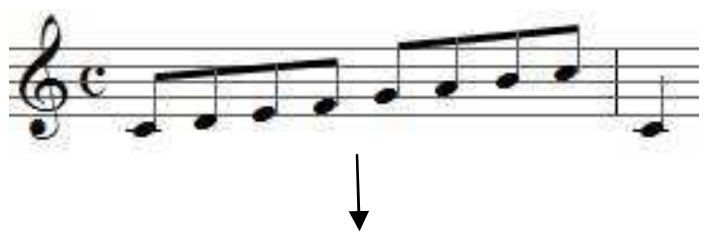

Tomar cuidado para não esmagar certas notas. Quando chegar ao lá agudo devo fazer duas ou três vezes em andamento rápido dizendo $\mathrm{y}-\mathrm{i}-\mathrm{y}-\mathrm{i}$ afim de obter a altura e a flexibilidade.

Senti-me muito melhor no "Sento nel core", acho que melhorei em muita coisa.

"Sento nel core"

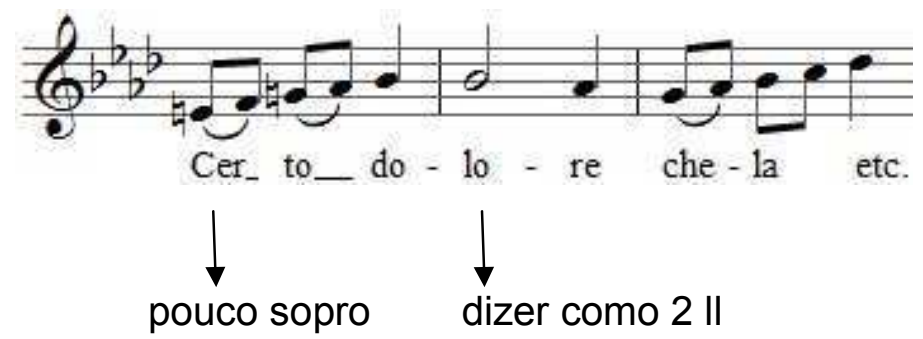

Dona Vera achou que eu fiz um progresso maior do que ela esperava.

\section{Quinta-feira, 13 de Janeiro de 1938}

$\left(23^{\mathrm{a}}\right.$ aula)

Fui muito bem no exercício; cheguei ao lá agudo e voltei ao si grave. Em seguida cantei pela primeira vez esse exercício: 


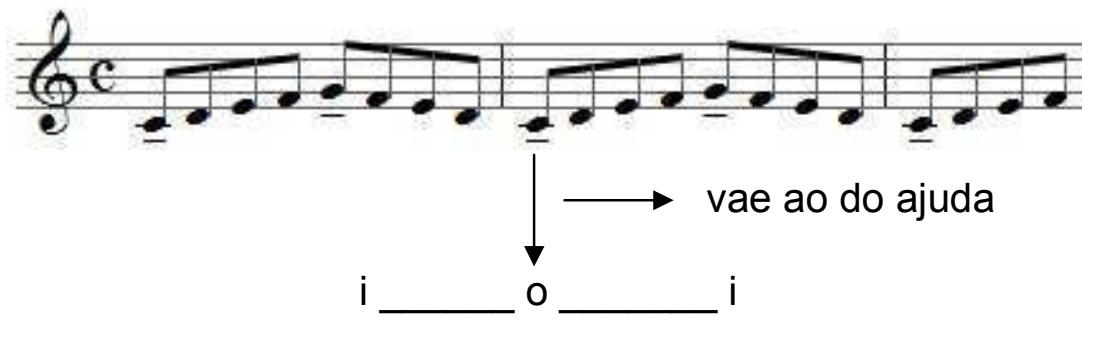

Segunda-feira, 17 de Janeiro de 1938

$\left(24^{\mathrm{a}}\right.$ aula)

Dona Vera estava hoje encantadora como sempre, exigente como nunca. Aconselhoume a fazer esse exercício que escrevi na pagina anterior, em diversas vogais para que todas fiquem na altura de $\mathrm{i}$.

Sábado, 22 de Janeiro de 1938

(25aula)

Fui à lição certa de não cantar bem por me sentir meio adoentada com muita dor no estomago. Dona Vera achou que eu fiz um progresso enorme. Para a próxima levarei o "Amarilli" de Caccini. Dona Vera achou conveniente estudar as vocalizes de fronte ao espelho com dois dedos entre os dentes para que a boca fique sempre aberta igualmente e para impedir que o queixo vá para frente.

Segunda-feira, 24 de Janeiro de 1938

(não houve aula)

Terça-feira, 25 de Janeiro de 1938

(26 aula)

Na lição de hoje fui bem no Scarlatti, fiz uns progressinhos e no "Comme raggio di sol", estacionei.

Quinta-feira, 26 (erro, deve ser 27) de Janeiro de 1938

(27 aula)

Dona Vera passou-me um novo exercício que é o seguinte: 


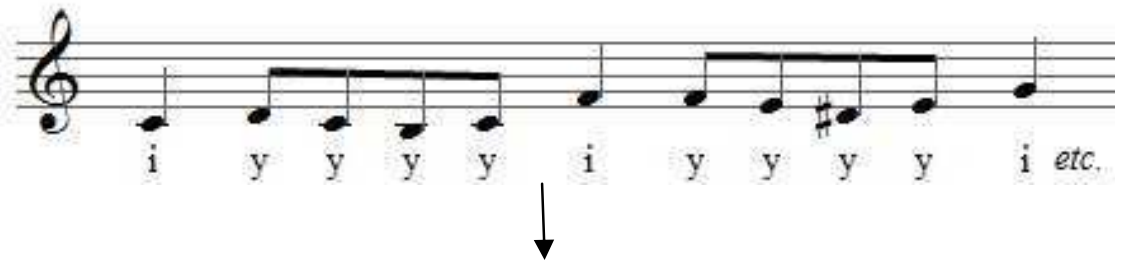

Cantar em todas as vogais subindo primeiro em i, e, na descida empregar o, a, etc.

O "Amarilli" nada houve a corrigir, Dona Vera quer somente mais altura, mais simples e mais sonoro. Para a próxima aula levarei o "Vergin tutt'amor" de Durante.

\section{Sábado, 29 de Janeiro de 1938}

(28a aula)

Considero-me feliz com a lição de hoje. As vocalizes foram bem. Dei pela primeira vez "Vergin tut'amor" que só houve a corrigir falta de altura em certos trechos.

\section{Segunda-feira, 31 de Janeiro de 1938}

(29a aula)

Dona Vera deu-me hoje a ultima aula pois ela nos vai deixar alguns dias para ir ao Rio. Cantei bem o "Vergin tut'amor".

"Vergin tut'amor

$(1684+1755)(F$. Durante $)$

Esta musica deve ser cantada toda na mesma altura, no mesmo plano, muito flexível. Devo prestar atenção nos seguintes pontos:

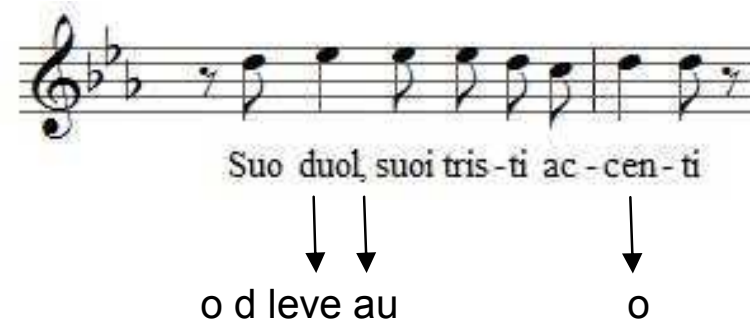



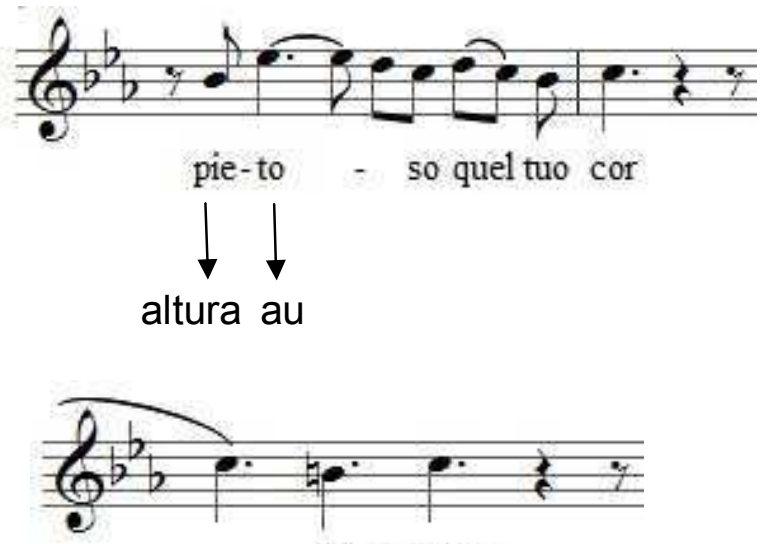

A - mor!

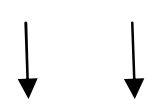

au au

O "Amarilli" devo fazer mais simples e mais cheio de altura. Tomar cuidado para não tremer as notas.

“Amarilli" (1550 + 1618)

Moderato $=66$
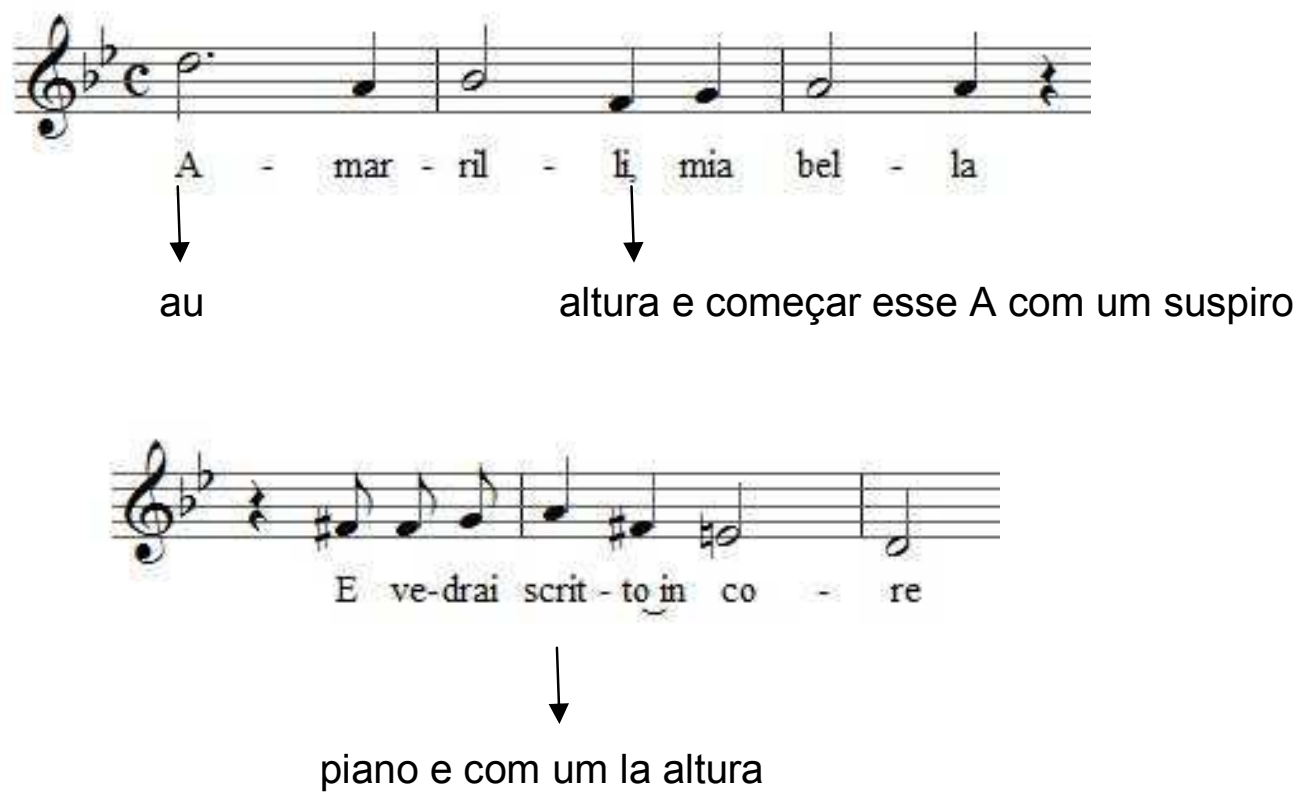

(Dona Vera deu férias no dia 31 de Janeiro e recomeçou com as aulas no dia 7 de Março) 
Segunda-feira, 7 de Março de 1938

(30a Aula)

Depois de quase um mês de férias, recomecei hoje com as lições de Dona Vera. Cantei três exercícios novos.

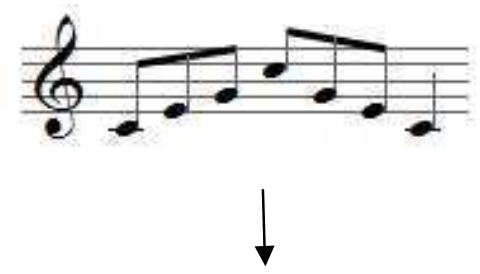

Deve ser cantado em [o] com altura e flexibilidade e pouquíssino sopro.
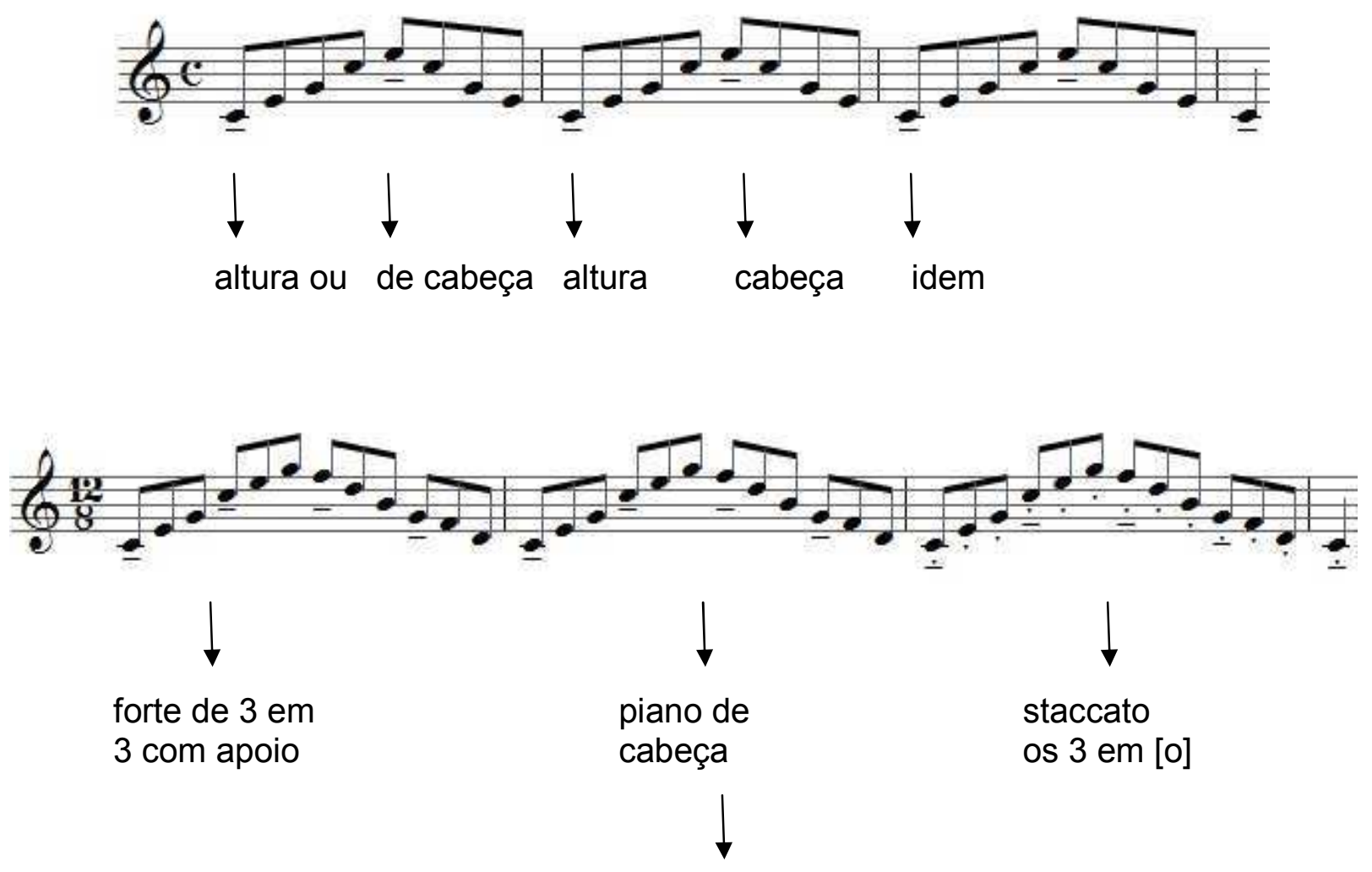

os 3 com a mesma respiração 
Quinta-feira, 10 de Março de 1938

(31ªula)

Estou bem melhor inegavelmente mas... para chegar onde quero... preciso de paciência !... Cantei os exercícios. E o "Vergin tut'amor" que eu imaginei ter estudado bem não está do gosto de Dona Vera.

Sábado, 12 de Março de 1938

$\left(32^{\mathrm{a}}\right.$ aula)

Sinto-me mais desembaraçada no cantar e no agudo, u, aquele exercício stacato fui ao agudo.

\section{Segunda-feira, 14 de Março de 1938}

(33 aula)

Embora eu me sentisse muito nervosa cantei bastante bem. Fiz progresso nas vocalizes. Dei hoje pela primeira vez "Quella fiamma che m'accende" de Marcello e "Sebben crudele" de Caldara.

\section{Quinta-feira, 17 de Março de 1938}

(34 aula)

A lição de hoje foi primeira lição onde eu percebi ter agradado Dona Vera. Os exercícios foram bem. Dona Vera ficou satisfeita com a musica de Marcello foram as seguintes as suas explicações:

Quella fiamma che m'accende

$(1686+1739)($ B. Marcello $)$

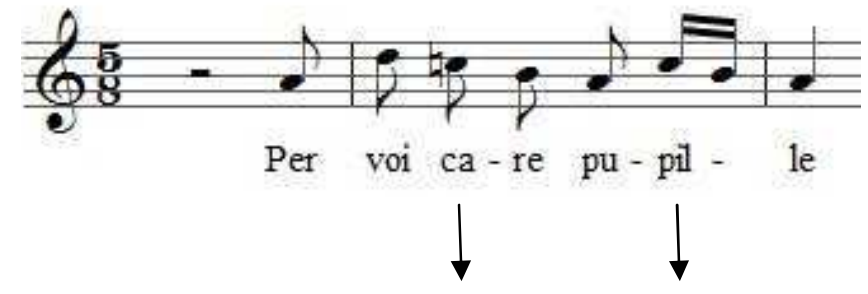

fazer claros os acentos tônicos. 


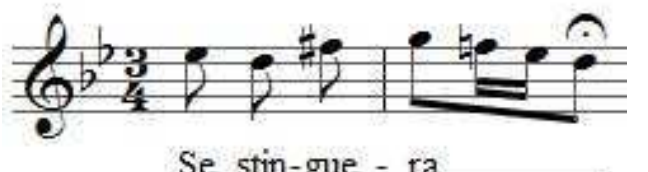

Se stin-gue - ra

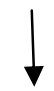

altura au
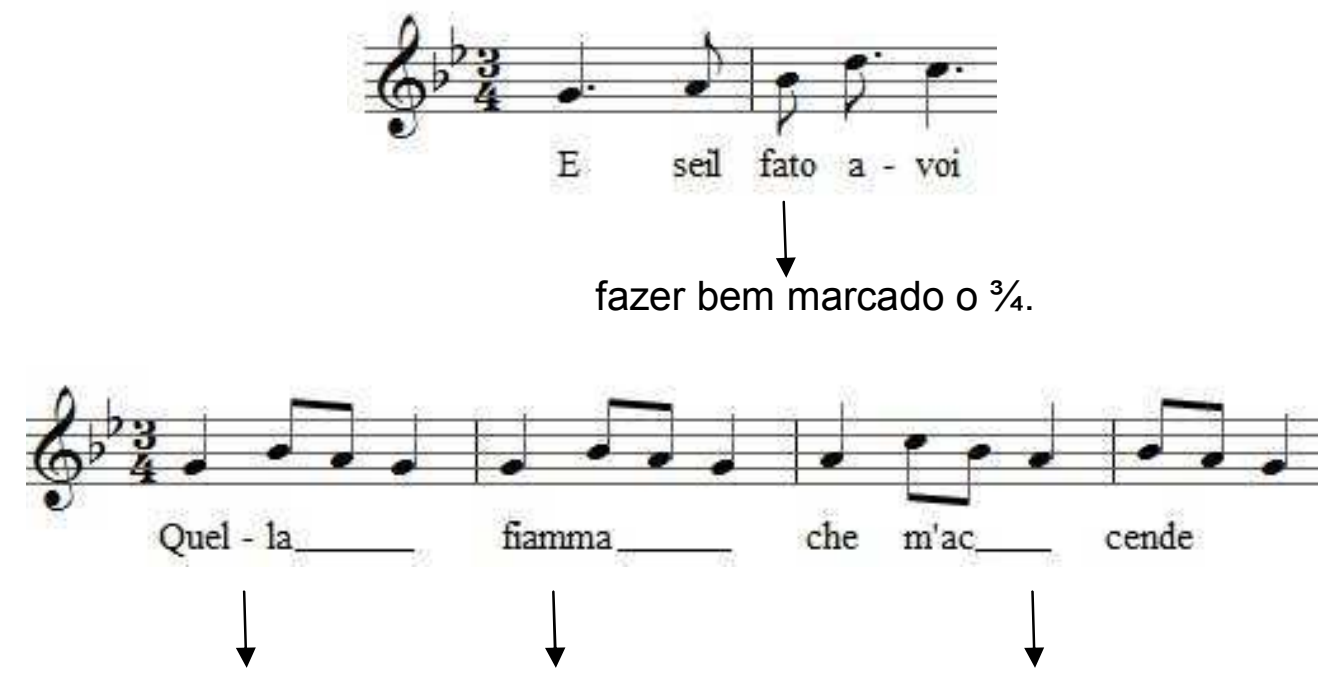

sentir bem as linhas dobradas.

Dona Vera notou em mim grandes progressos.

\section{Segunda-Feira, 21 de março de 1938}

$\left(35^{\mathrm{a}}\right.$ aula)

Dona Vera mandou-me deixar "Sebben crudele" e "Quella fiamma che m'acende" pois achou-as bem. Passou-me para a próxima aula "Apaisemetns" de Beethoven e alguns de "Les amours du poète". Dei pela primeira vez "Les berceaux" de Fauré.

Aqui ficam as explicações que Dona Vera deu das músicas que apresentei. As duas vão bem na minha voz, sinto facilidade. 
Sebben crudele

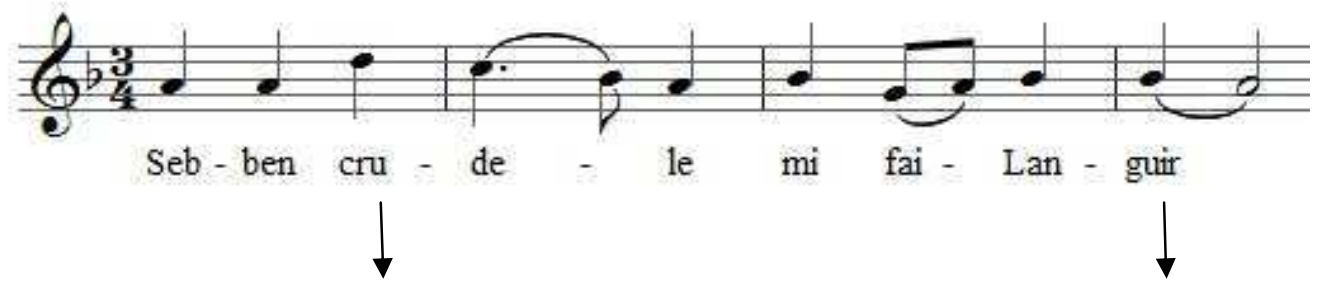

pouco sopro e flexibilidade.

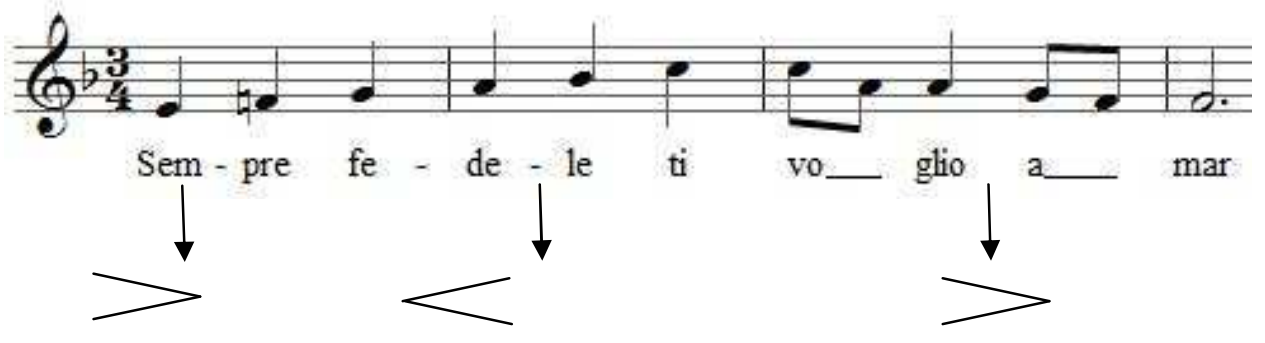

Les Berceaux
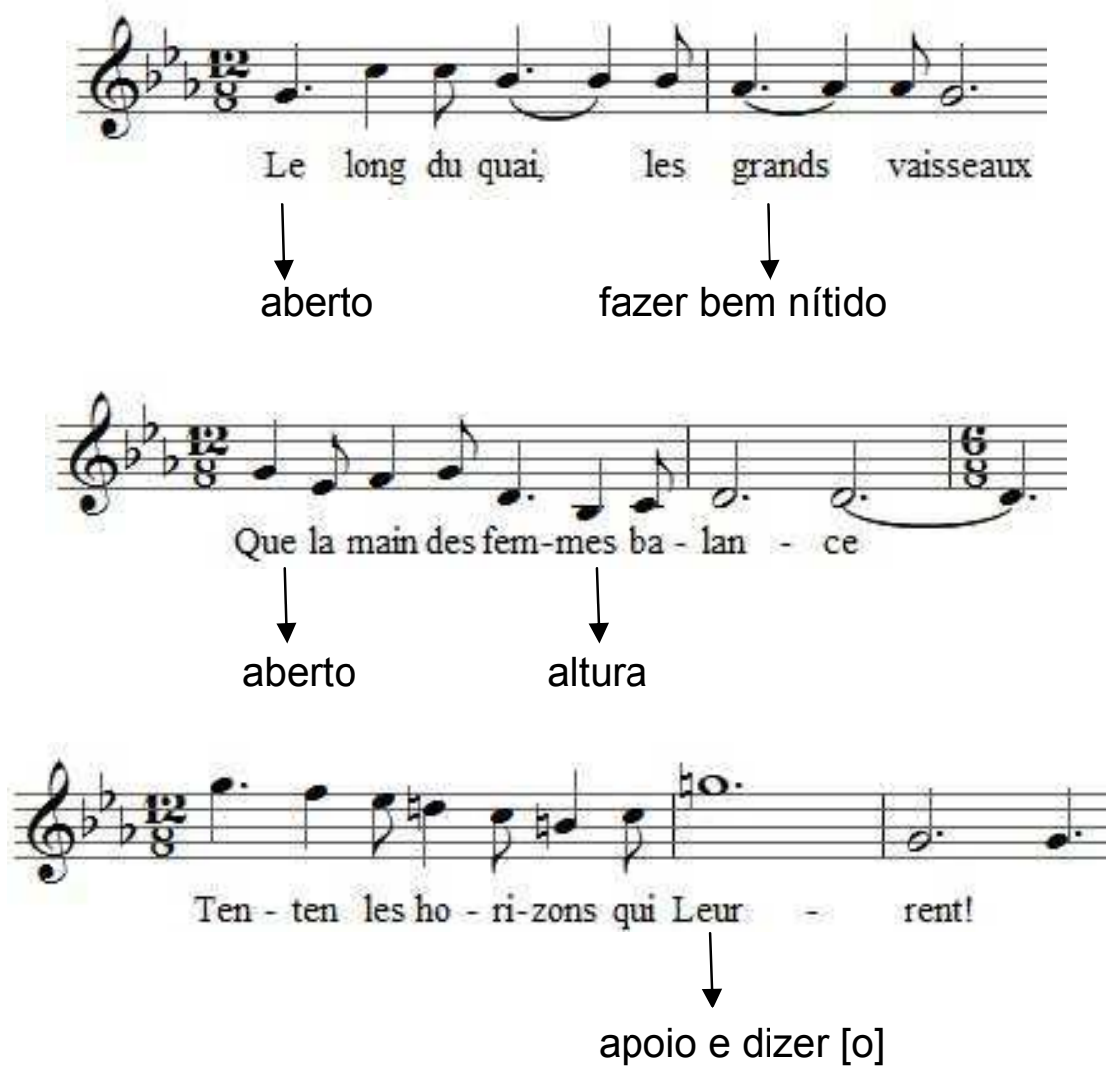


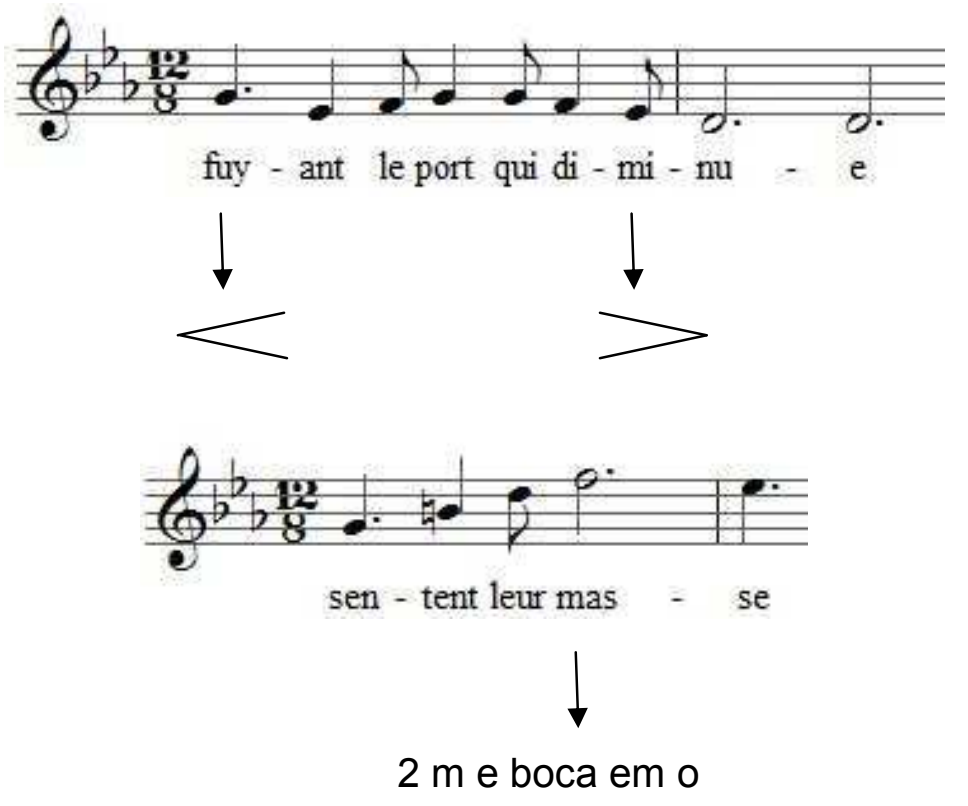

Sábado, 9 de Abril de 1938

(36 aula)

Fui bem nas vocalizes e hoje dei uma nova que é a seguinte:

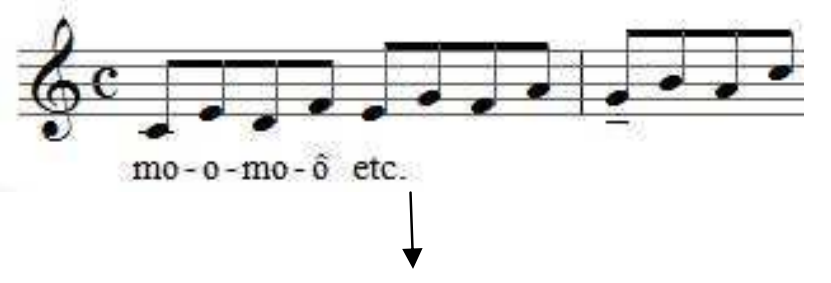

Dona Vera acha que eu faço o som muito carregado. Aconselhou-me a fazer em o, e em i, mordendo o polegar para que a boca fique aberta da mesma forma. Devo tomar cuidado para não esmagar o som. Para adquirir flexibilidade devo empregar os $y$-y. 
Apaisements

$(1770+1827)($ Beethoven $)$

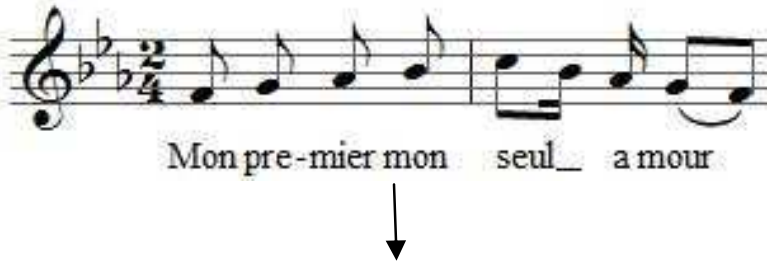

se quiser pode respirar aqui.

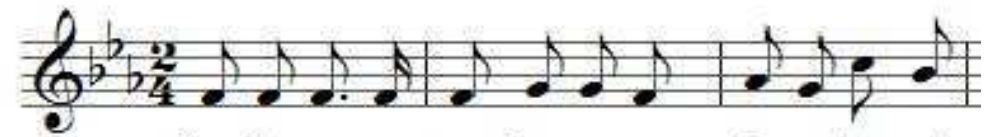

Sous le myr-te etsous les ro-ses bors_ jus qu'a

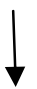

fazer claro e articulado.

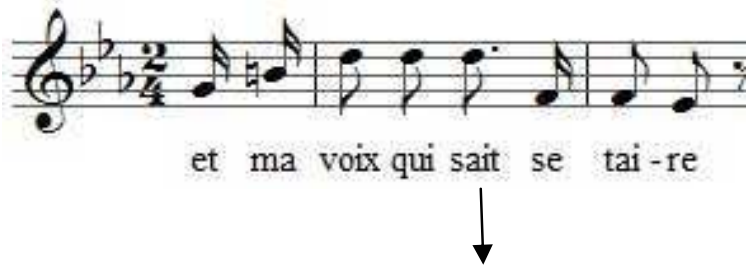

piano e no mesmo nível, quer dizer, fazer muito plano
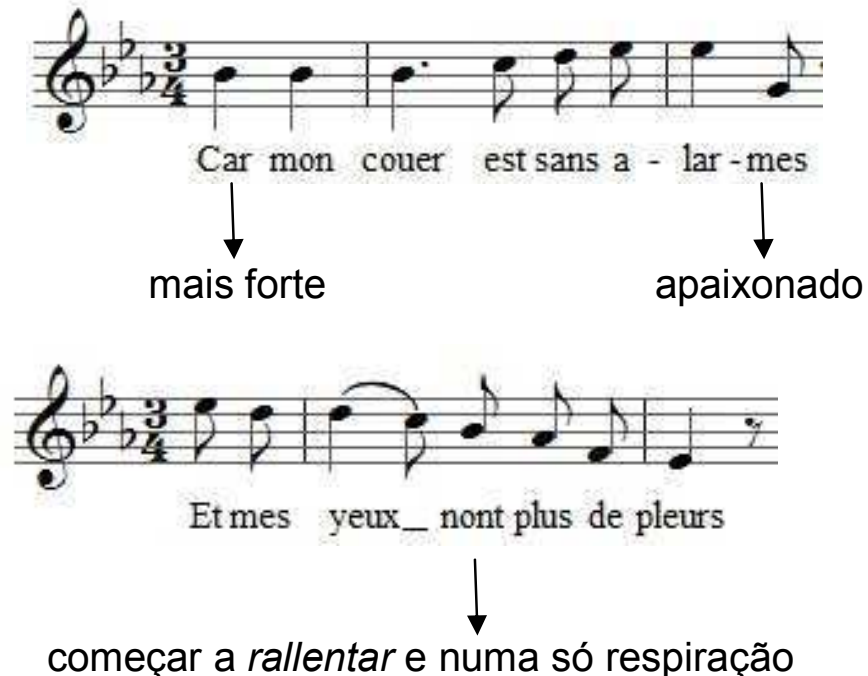
Automne

$(1845+\quad)($ G. Fauré$)$

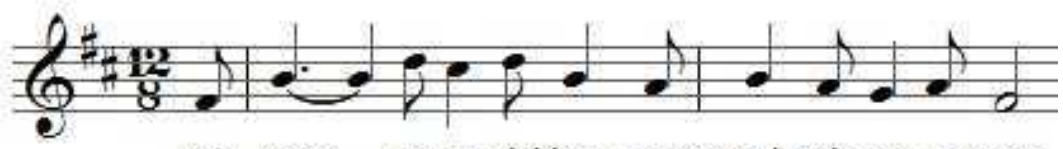

$\mathrm{Au}$ - tom _ ne au ciel bru meux aux ho ri-zon na vrans

melancólico no mesmo nível, piano, com spleen

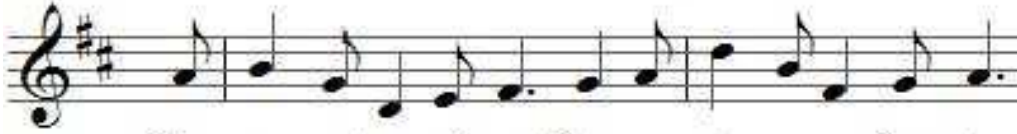

Par cou-rent en rê-vant les co- teaux en-chan-tes

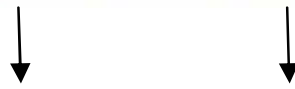

ré

não é rê

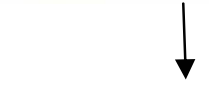

respirar aqui

e não depois de jadis.

Dona Vera gostou do "Les Berceaux", achou-o bem.

\section{Terça-feira, 12 de abril de 1938}

(37 aula)

Iniciei com o exercício (ia-iê-iy-iô-iu) que não foi propriamente mal. Este exercício devo estudar dessa forma:

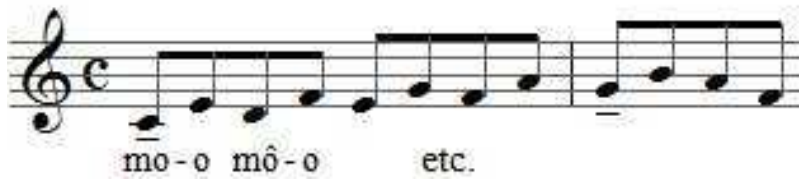

Devo subir e descer com altura e pensar nesse desenho $\uparrow$ altura

$\bigvee$ apoio

Quando estudar ir a la ou si agudo em mô ô mô - e voltar somente com a vogal o ou i. Fazer bem rápido marcando a primeira nota de cada compasso. 
Apaisements

(Beethoven)

Dona Vera acha que vou bem nessa música. Preciso somente fazer o andamento mais animado um pouco. E, no trecho:

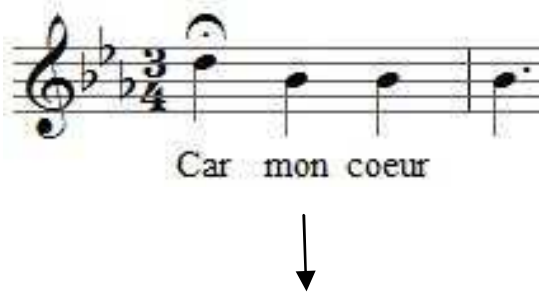

mais lento

Les Berceaux

$(1845+\quad)(G$. Fauré $)$

Está bem, só que no trecho:

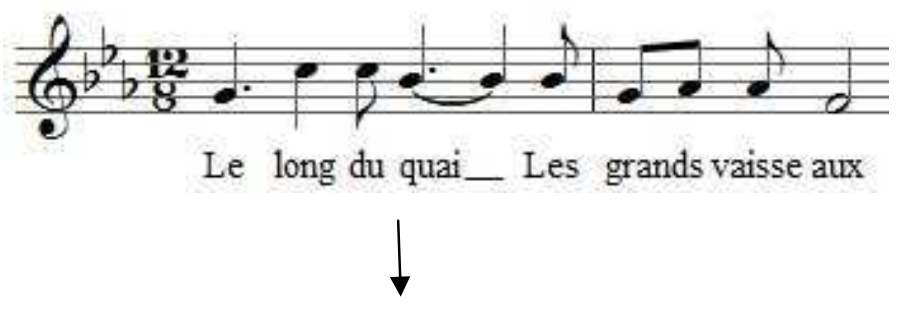

Preciso esperar mais umas notas pontuadas e também devo cantar em andamento mais animado.

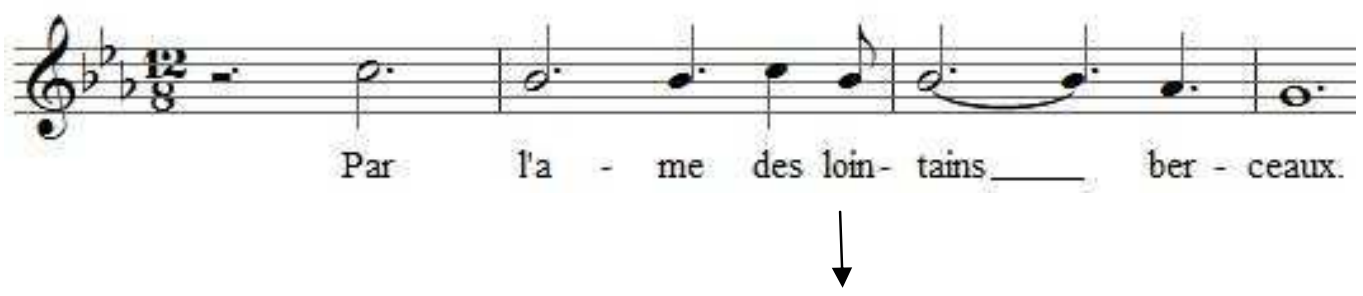

Devo fazer- loin - como se fossem dois II. Diz Dona Vera que falando assim parece que se está mais longe...

Tive novas explicações do Automne de Fauré. 
Automne

(G. Fauré)

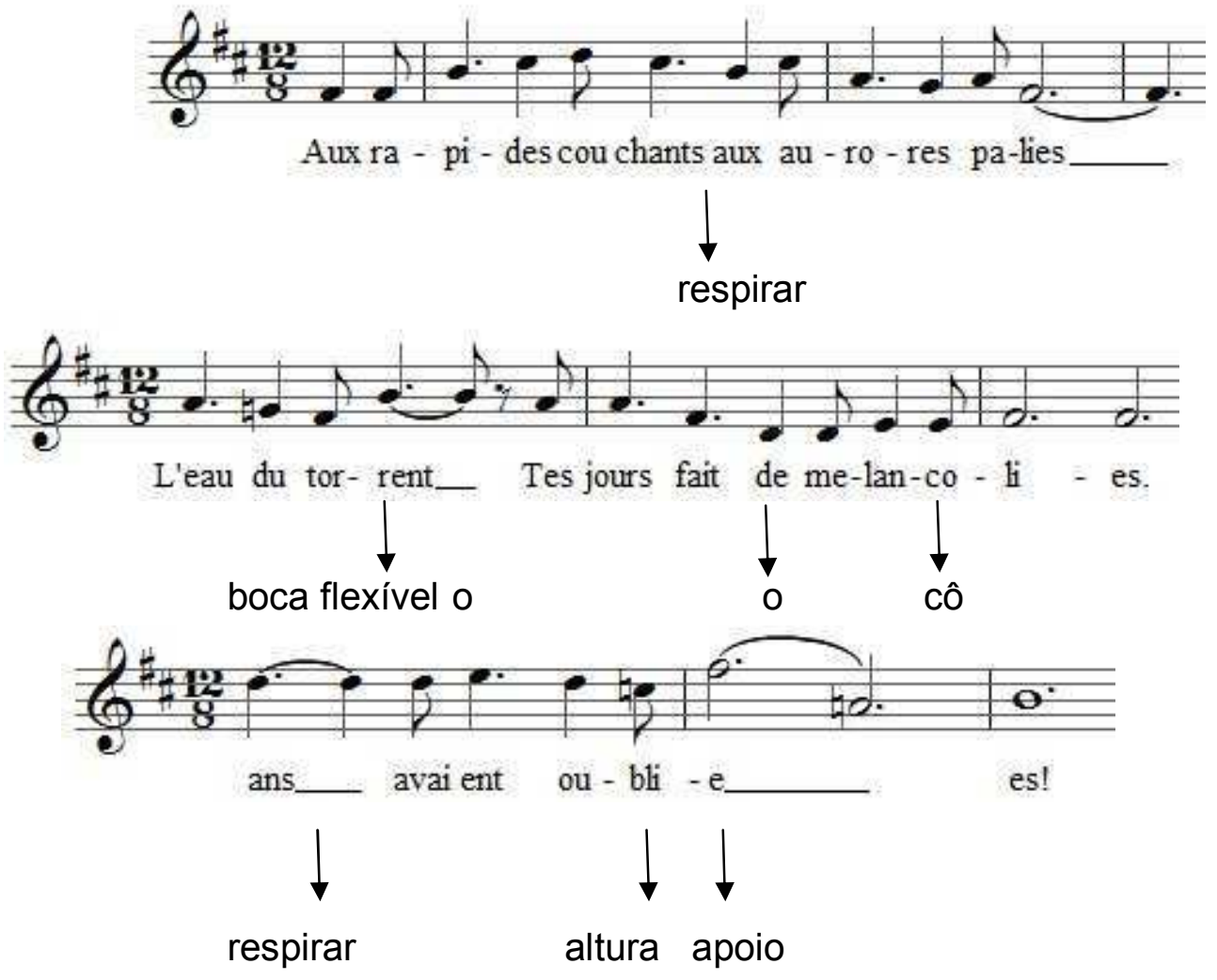

Observações minhas.

$(13 / 4 / 38)$

Fazendo hoje a minha hora de estudo, notei em mim os seguintes defeitos:

"COMME L'EAU DU TORRENT"

Estou fazendo muito na vogal, devo amolecer a língua e o queixo e dizer mais "torro".

"MES ESPRITS COMME S'IL"

Está sílaba; que é dita sobre a nota mi, estou fazendo uma caída, preciso por muita altura, colocar a nota em i.

"OU JADIS SOURIT MA JEUNESSE

Preciso/ não devo esmagar o i, falta maleabilidade.

AVAIENT OUBLIEE

Ainda não sinto bem o apoio e o alargamento do tórax, sinto que estou dando excessso de sopro.

Iniciei com "Le secret" de Fauré. 
Segunda-feira, 18 de abril de 1938

(38 aula)

Fui ao Municipal a fim de receber mais uma lição de Dona Vera. Hoje não dei vocalizes. Cantei "Les berceaux" que nada houve a corrigir. Em "Automne" nada fiz de ruim, mas Dona Vera quer que eu interprete no mesmo nível e com spleen.

\section{Quarta-feira, 20 de abril de 1938}

(39a aula)

Dei pela primeira vez esse exercício:

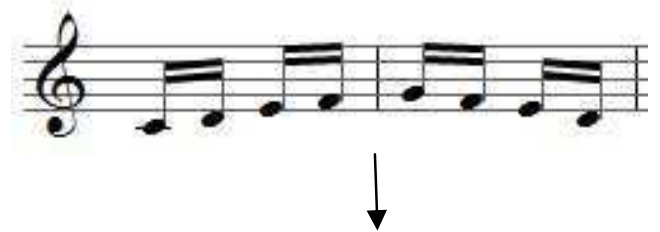

fazer primeiro com i depois passar às outras vogais

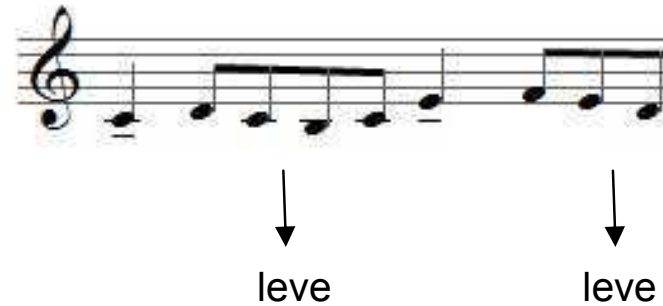

e na nota antes dos grupetos por o queixo bem para traz como se ele fosse - "João bobo".

Le Secret

(G. Fauré)

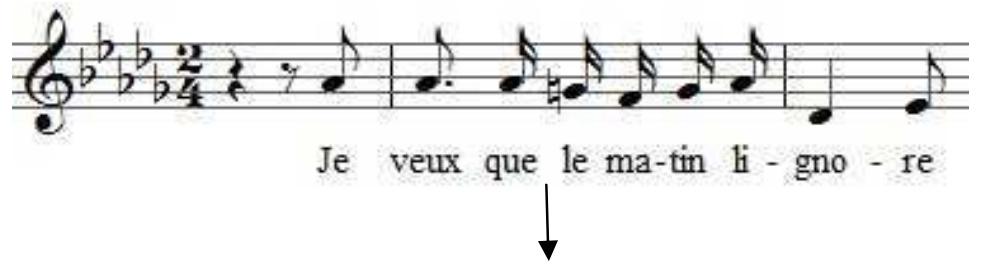

mais suave, natural, queixo mole

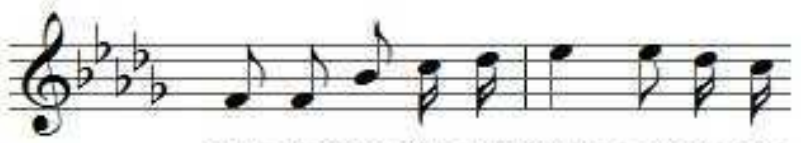

vent de l'au-be sans bruit comme une

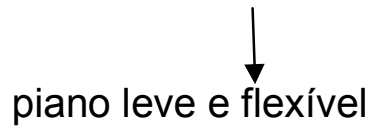



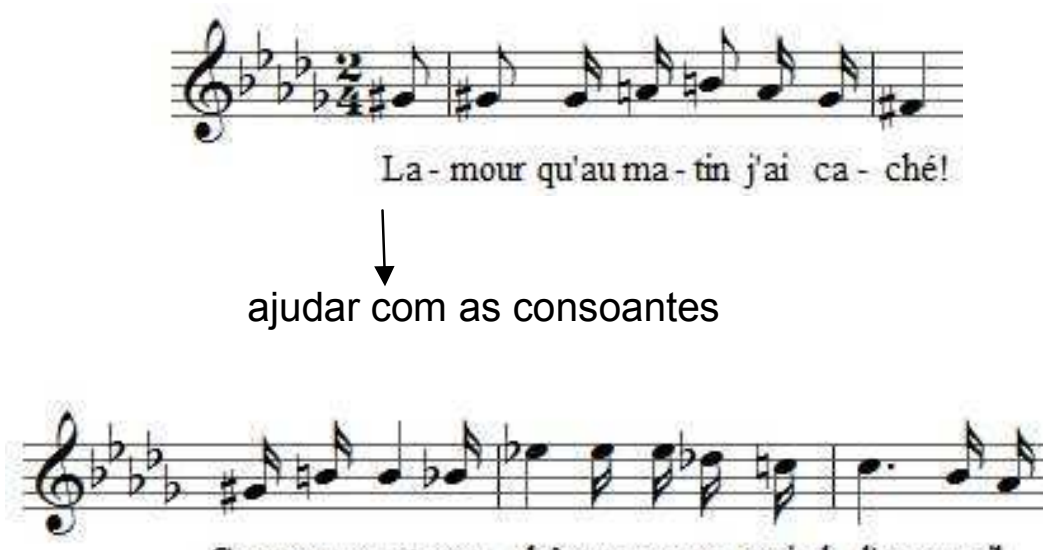

Coeur ou-vert pen - chê comme un graind d'encen sil
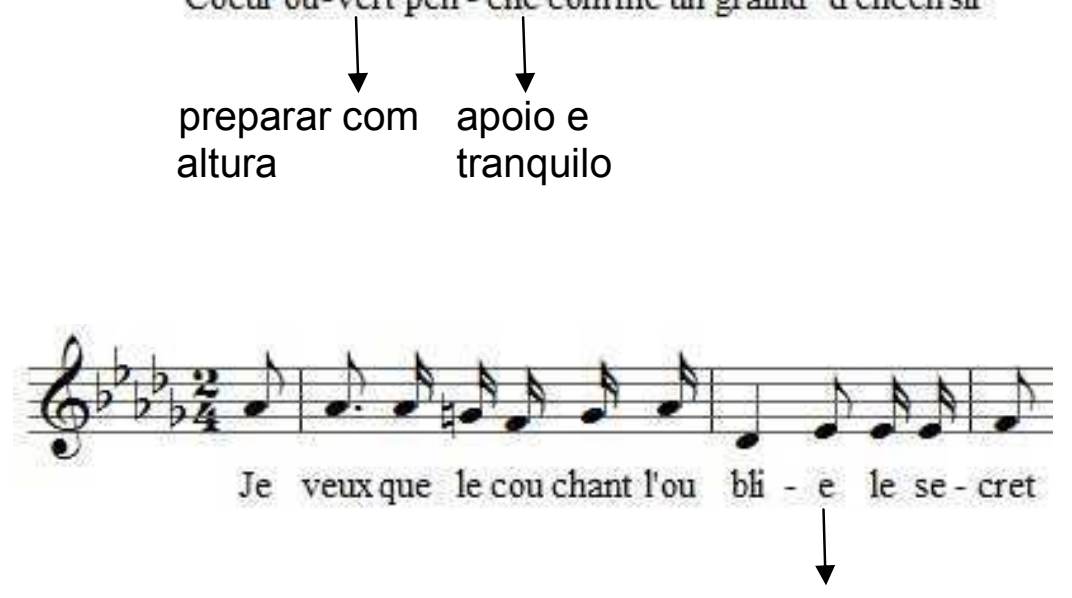

não fazer nasal, fazer na altura de i

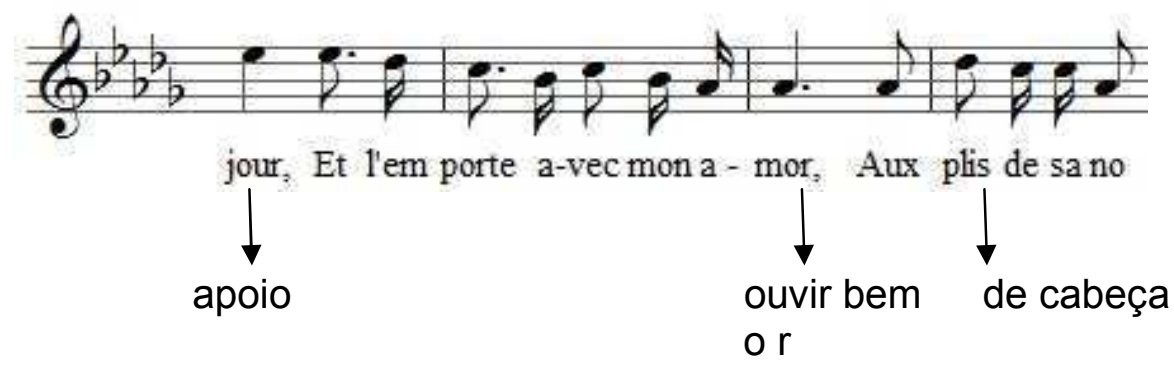


Sábado, 23 de abril de 1938

(40a aula)

$\mathrm{Na}$ escala de Lili Lehmann preciso por mais altura e mais naturalidade pois eu ainda dou excesso de sopro.

Quand Mai

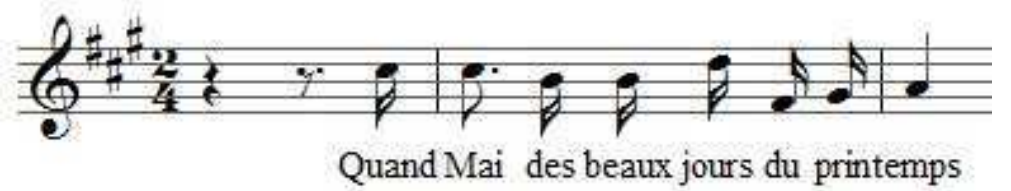

fazer tudo no mesmo nível, muito plano e com altura.

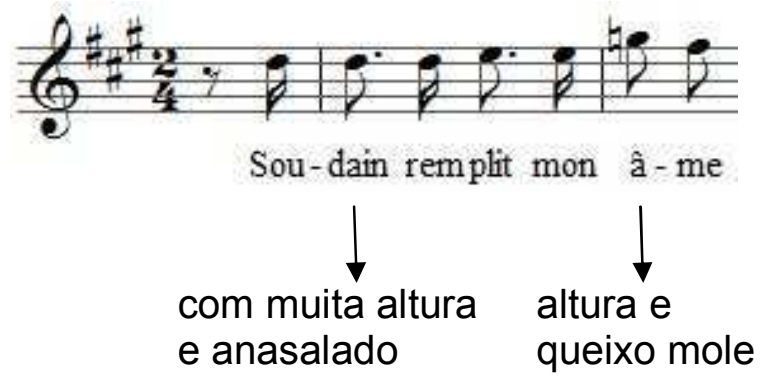

Estudar o "mon âme" fazendo dois sons a baixo até chegar ao si ou do agudo voltando depois a tonalidade em que a música está escrita. O exercício denota de cabeça que se deve aplicar no mon âme e o seguinte:

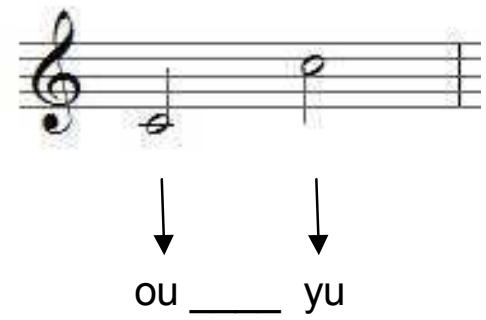


L’aurore, La Rose, Le Lys

(R. Schumann)

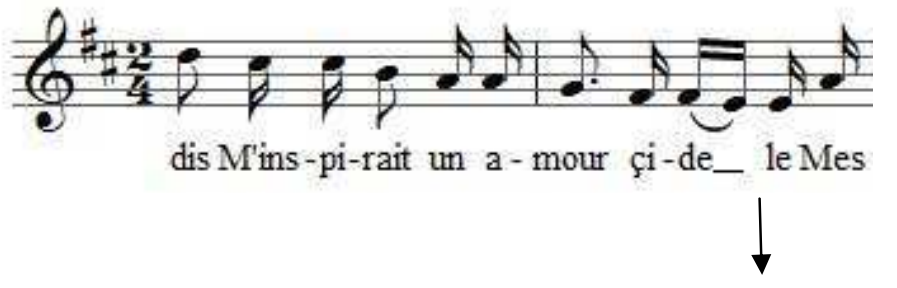

cantar sem respiração.

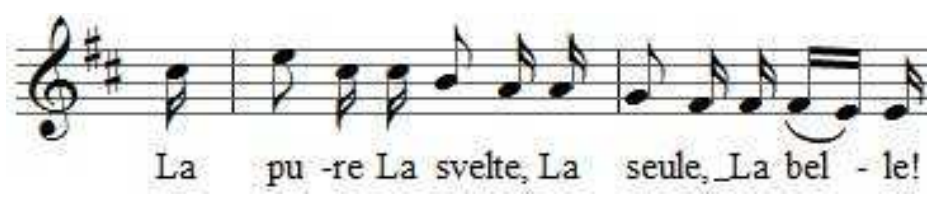

respirar

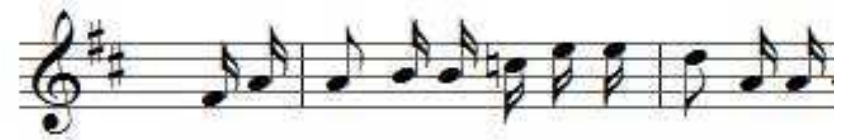

La co-lom-be, le lys, Et l'au - ro-re
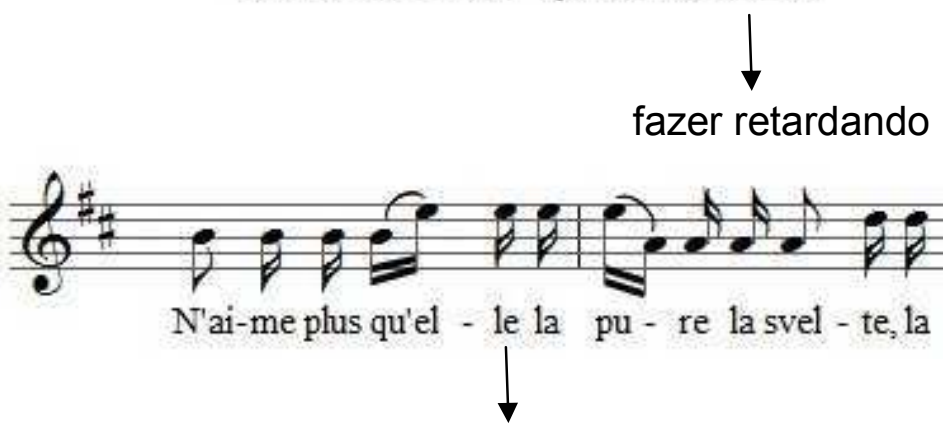

andamento igual ao inicio

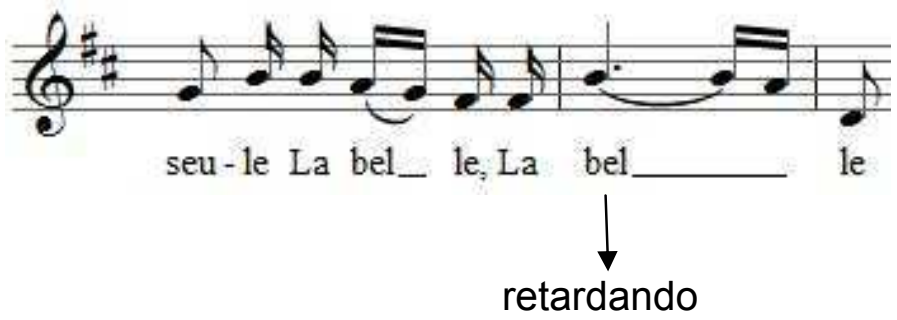




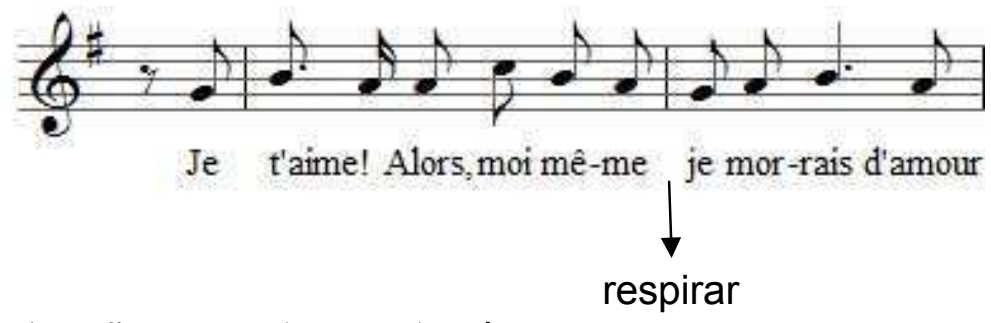

Preciso prestar atenção nas notas pontuadas.

\section{Quarta-feira, 27 de abril de 1938}

$\left(41^{\mathrm{a}}\right.$ aula $)$

Fiz um grande progresso nas vocalizes; o sopro está equilibrado, tenho bastante altura e o queixo está mole e flexível.

Mes larmes

(R. Schummann)

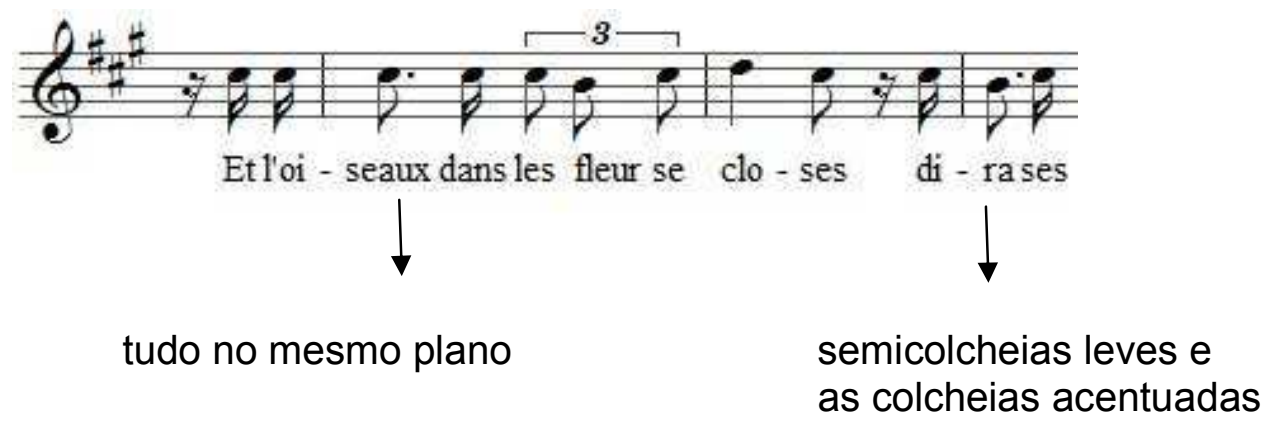

Quinta-feira, 28 de abril de 1938

$\left(42^{\mathrm{a}}\right.$ aula)

Cantei "Automne" e "Les Berceaux" que Dona Vera achou bem. "Le secret" foi regular. Para a próxima aula vou levar "Chanson du Pappion" de Campra. 
Sábado, 30 de abril de 1938

$\left(43^{\mathrm{a}}\right.$ aula)

Dona Vera passou-me dois exercícios novos:

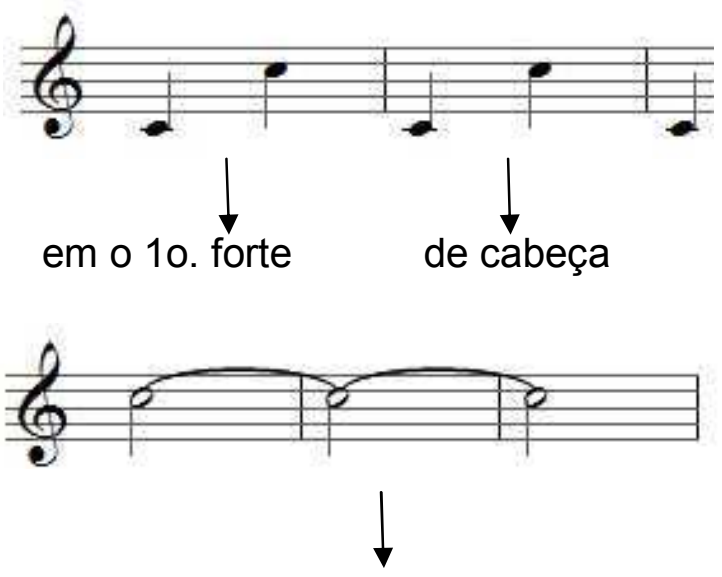

iniciar pianíssimo em o, ir aumentando ainda de cabeça e com altura de i começa a fazer o som forte com muita elasticidade no tórax, volta com pouco sopro ao som de cabeça.

Chanson du Papillon

$(1.660+1744)$ (Campra - Wekerlin)

Esta música, como leitura, eu não poderia ter dado mais certa e mais entendida. Quanto ao compasso nada houve a corrigir, felizmente, pois eu acho humilhante fazer erros desse gênero.

Dona Vera apenas corrigiu a parte vocal.

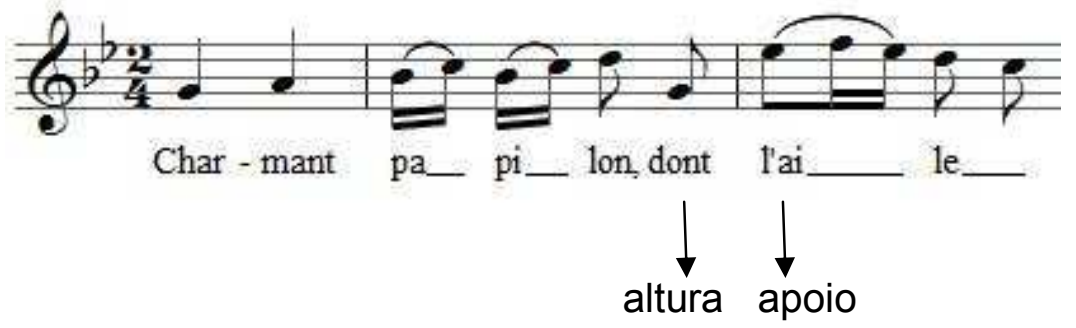



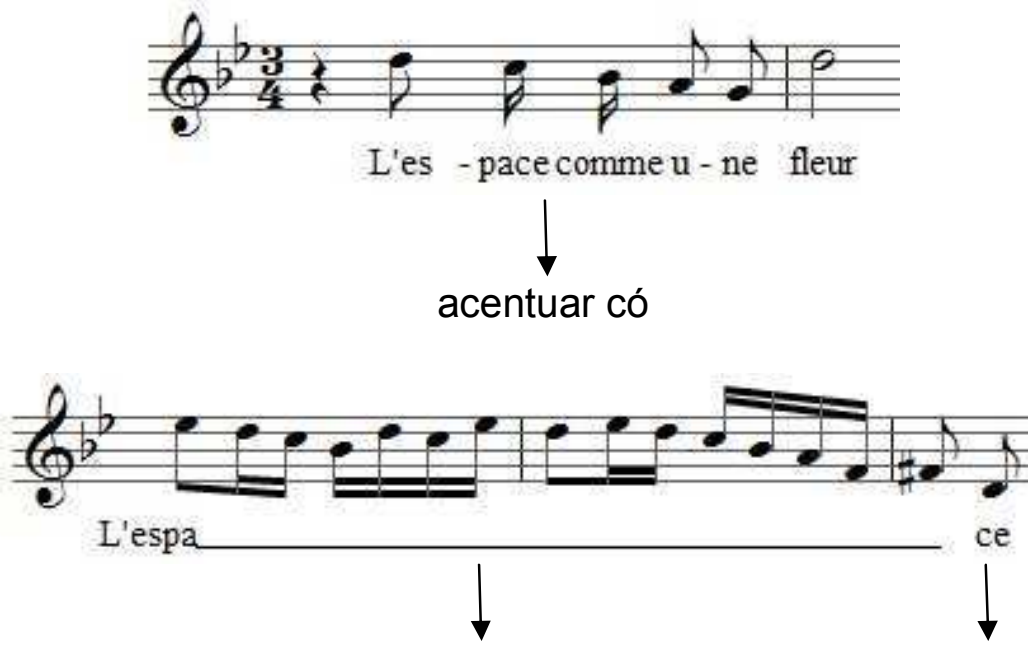

não fazer nasal altura

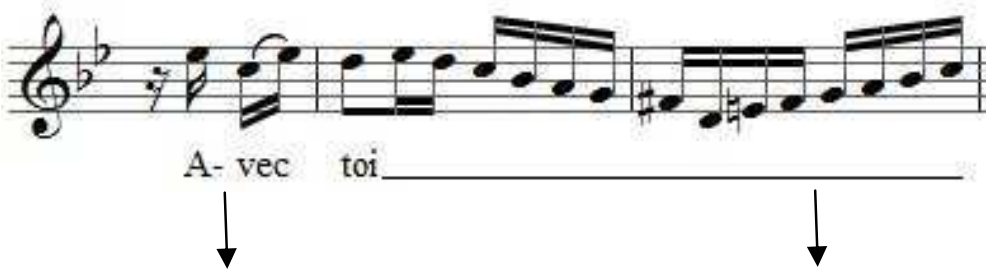

dizer aveec fazer compasso que segue de cabeça.

Preciso cantar com flexibilidade toda a música mormente as vocalizes.
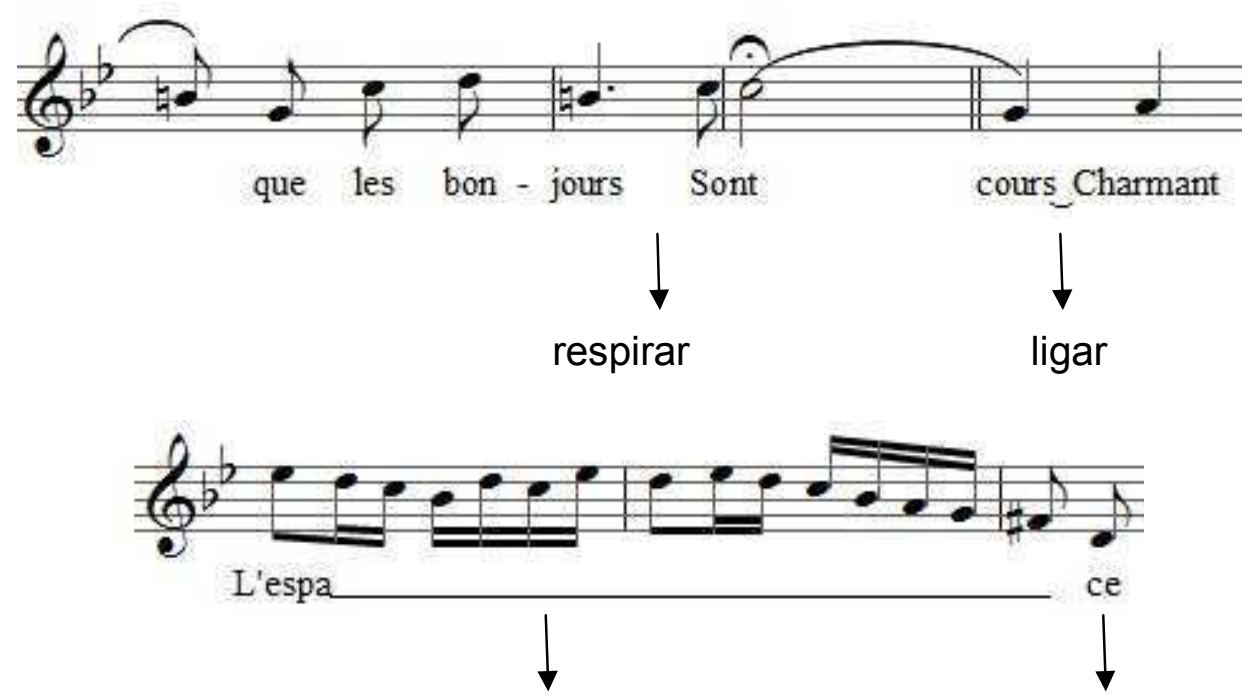

não fazer anasalado

com altura 


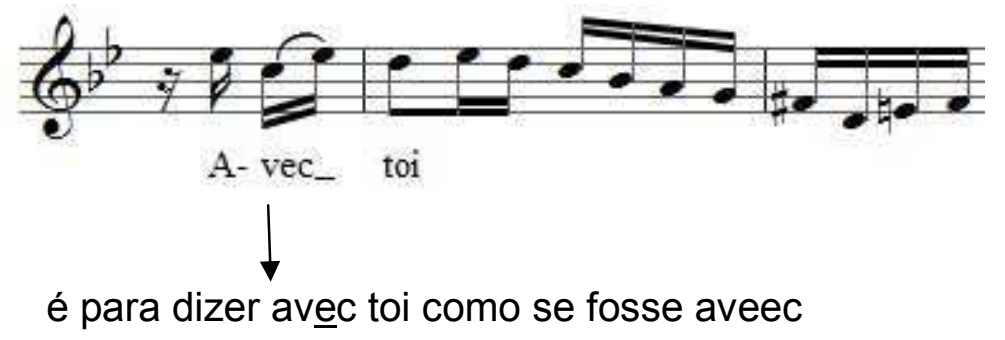

Observações minhas

$(3 / 4 / 1938)$

Hoje cedo, ao fazer os meus quarenta minutos de vocalizes, verifiquei com pesar que os últimos exercícios passados por Dona Vera não estão como eu desejo. Estudei o $1^{*}$ das duas oitavas, com um lápis sobre a língua afim de impedi-la de enbolar. Sinto que quando vou acabar a nota aguda para fazer a oitava forte o agudo sai muito soprado. Experimentei a fazer da forma que Dona Vera explicou ao telefone. Fazer a $1^{*}$ oitava piano e depois que estiver na nota aguda aumentar. Com esse processo consegui melhorar consideravelmente.

\section{Quarta-feira, 4 de maio de 1938}

$\left(44^{\mathrm{a}}\right.$ aula $)$

Dei uma lição digna de ser apresentada, bem de meu gosto. Iniciei com o exercício das duas oitavas que Dona Vera achou grandes progressos; o sopro está equilibrado e as notas agudas estão sonoras e sem esforço. "Chanson du Papillon" foi muito bem e poucos erros teve. Cantei com desembaraço, com facilidade no andamento rápido. Dona Vera ficou satisfeitíssima com a maneira que cantei.

Chanson du Papillou

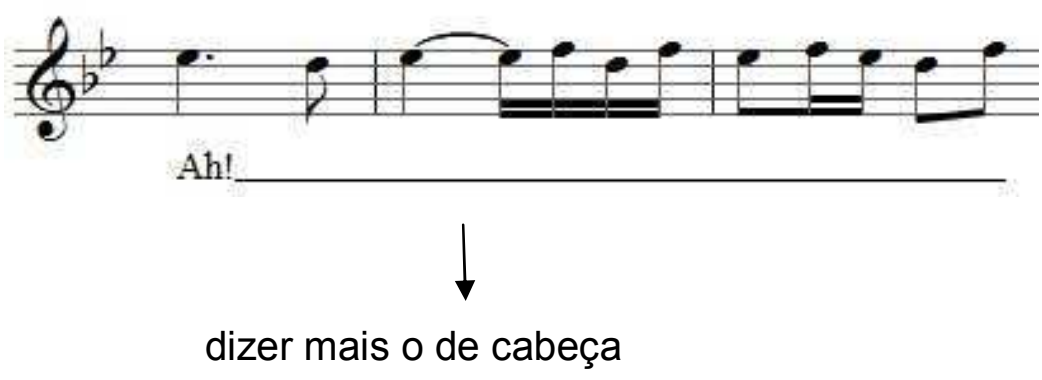




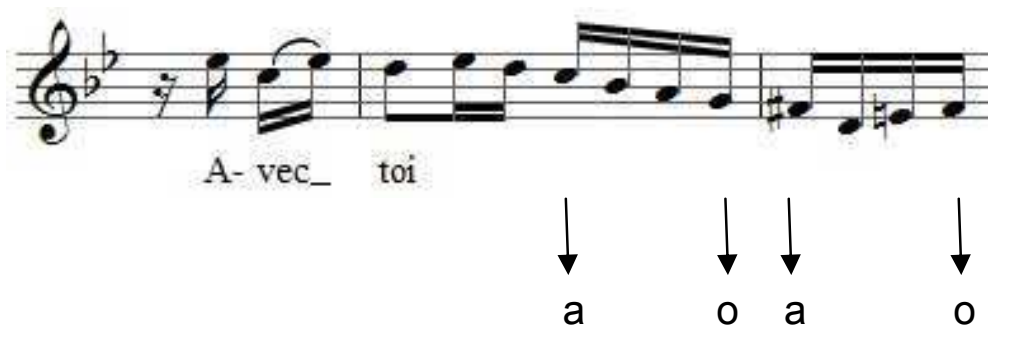

Segunda-feira, 9 de maio de 1938

(45 aula)

Dei hoje como surpresa o "Rencontre" de Fauré pelo qual fui cumprimentada por dona Vera. Ela achou muito bem estudado, gabou a dicção e corrigiu algumas coisas que, com a sua inteligência e com a sua arte insuperável fez ficar o "Rencontre" muito mais delicioso e artístico.

Estou cada vez mais encantada pela escola de dona Vera. Cada explicação sua é um raio de luz.

Rencontre

(Fauré)

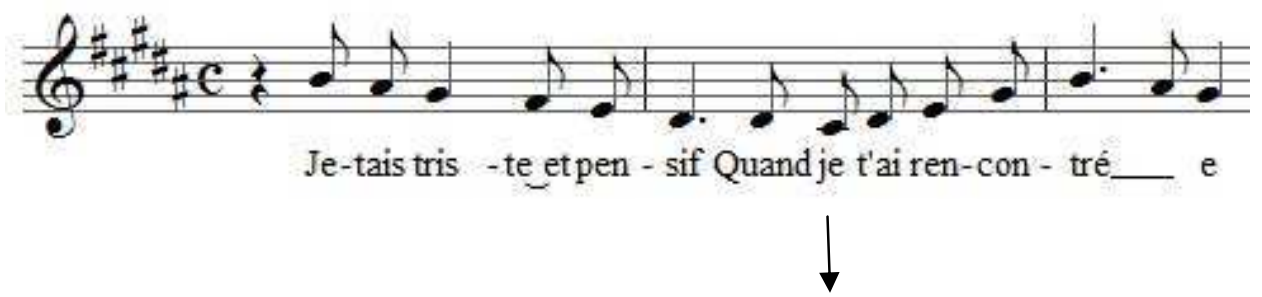

não fazer fechado

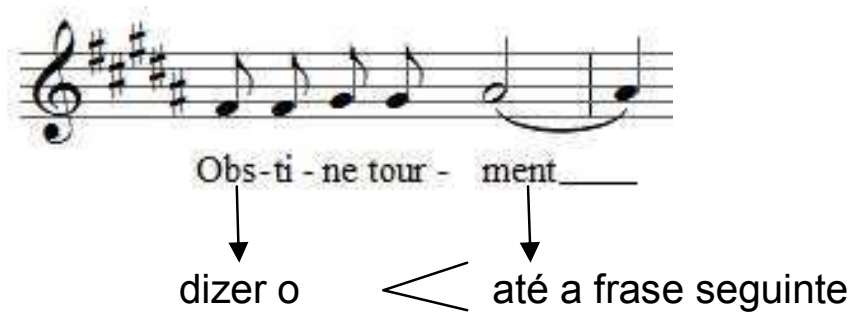




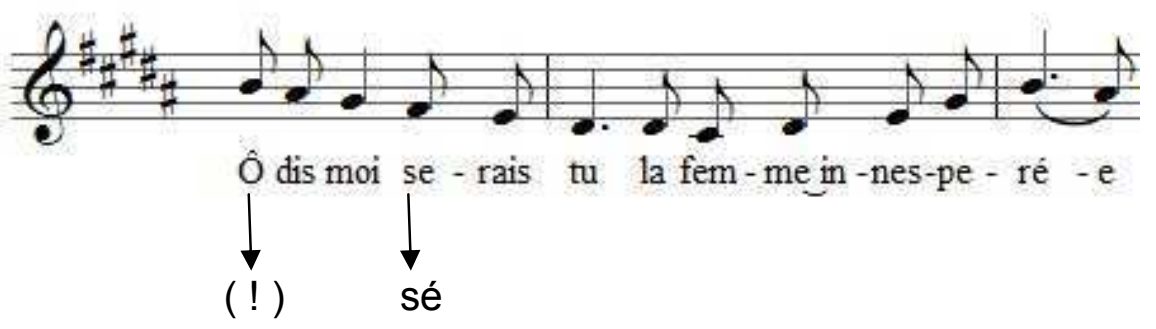

dizer toda a frase alegre e solta
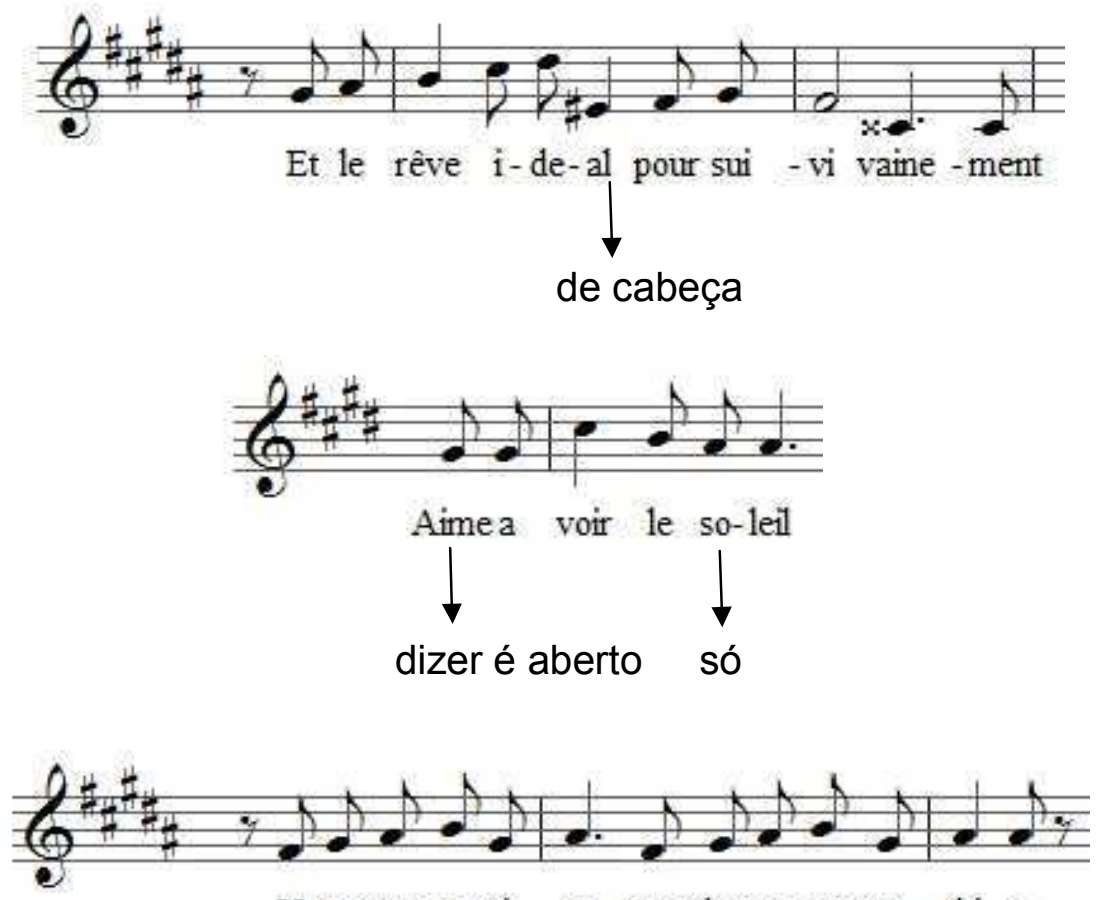

U-ne mys-te-ri - eu-se et douce sym-pa - thi - e fazer bem sss toda a frase falada

\section{Observações minhas}

(10/maio/1938)

Hoje à tardinha fui estudar um pouco e, ao repassar as minhas músicas notei em mim os seguintes defeitos:

\section{Automne}

(Fauré)

Sinto-me meio aflita nas respirações. Naquele trecho:

OU JADIS SOURIT MA JEUNESSE - Acho difícil dizer toda a frase na mesma respiração, não consigo ainda agüentar até a pausa. 


\section{Quarta-feira, 11 de maio de 1938}

\section{(46 aula)}

Na lição de hoje não fui bem. No exercício:

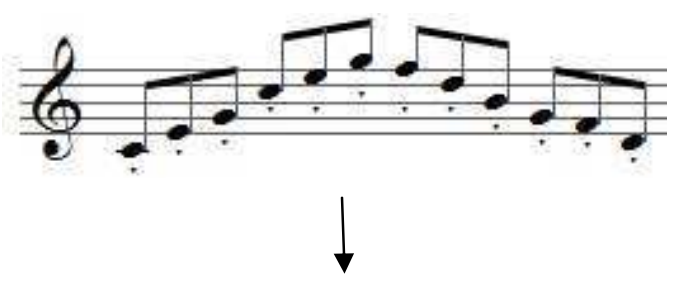

fazer três vezes staccato. Dona Vera notou que eu embolo a língua e endureço o queixo. Ensinou-me a estudar bem anasalado on.

\section{Quinta-feira, 12 de maio de 1938}

(47 aula)

A minha lição de hoje foi uma das melhores, ou por outra, umas das mais aproveitáveis de minha vida. Cantei primeiro a "Chanson du Papillon" que foi muitíssimo bem. Em seguida dei o "Rencontre" de Fauré que preciso fazer mais dialogado... Depois "Automne" que Dona Vera quer mais no mesmo nível. O "Secret" foi bom. "Les berceaux" preciso acentuar mais as colcheias. Para mim o melhor, na lição de hoje foi que Dona Vera deu aula somente para mim. "Apaisement" cantei horrivelmente! Muito glacial, sem expressão e sem vontade. Hoje é que melhor pude sentir a paródia que eu fiz para "Après un revê"

\section{Segunda-feira, 16 de maio de 1938}

\section{$\left(48^{\mathrm{a}}\right.$ aula)}

Cantei bastante bem. Iniciei com "Rencontre" que dona Vera achou bem melhor. Dei pela primeira vez o "Toujours" e Adieu" que , como leitura não poderiam ser melhores. Não pude entender bem as explicações de Dona Vera sobre esses dois Fauré. Sei apenas que ela notou alguns erros de emissão e excesso de sopro em certas notas.

Quinta-feira, 19 de maio de 1938

(49a aula)

A aula do de hoje foi só de vocalizes. Cantei inefavelmente muito bem. Dona Vera achou que eu melhorei muito com o estudo anasalado que eu fiz. 


\section{Segunda-feira, 23 de maio de 1938}

$\left(50^{\mathrm{a}}\right.$ aula $)$

A minha lição de hoje foi relativamente boa. Diz Dona Vera que eu melhorei bastante mas... que há muito que corrigir. Foi hoje a primeira aula de interpretação. Achei meio complicado descrever nitidamente o modo de sentir e de interpretar certas frases, pois a minha maneira de sentir e de encarar as cousas, muitas vezes é bem diferente dos demais.

Toujours

(Fauré)

Dona Vera achou que eu dei à interpretação dessa musica uma paixão muito exagerada. E, achou que para eu equilibrar esse "fogo", preciso fazer mais nuances.
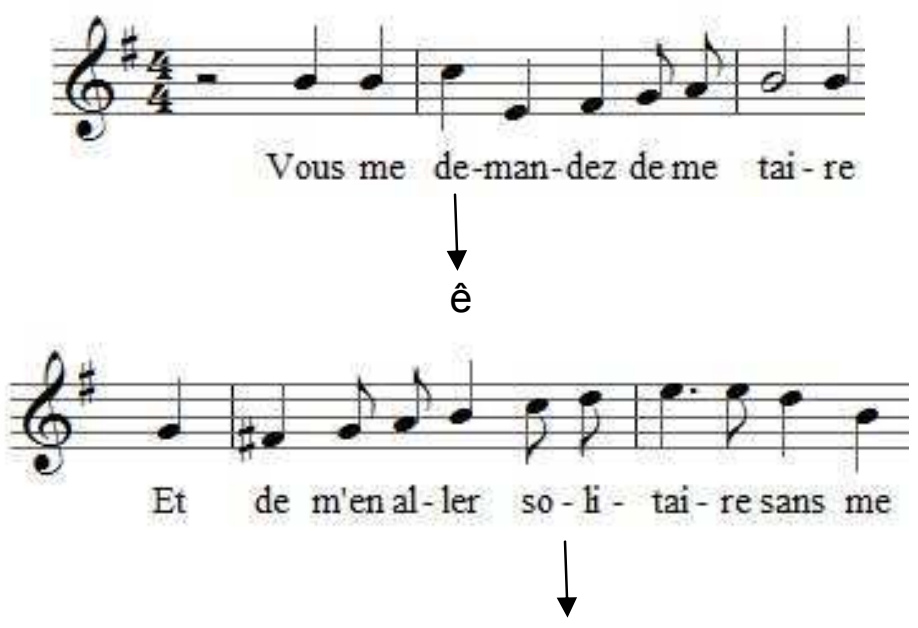

atenção nas colchêas

Adieu

$(1845+\quad$ (Fauré)

Dona Vera achou que a minha interpretação foi muito triste, muito nostálgica. Ela acha que eu devo empregar mais uma certa ironia, devo fazer meio displicente.

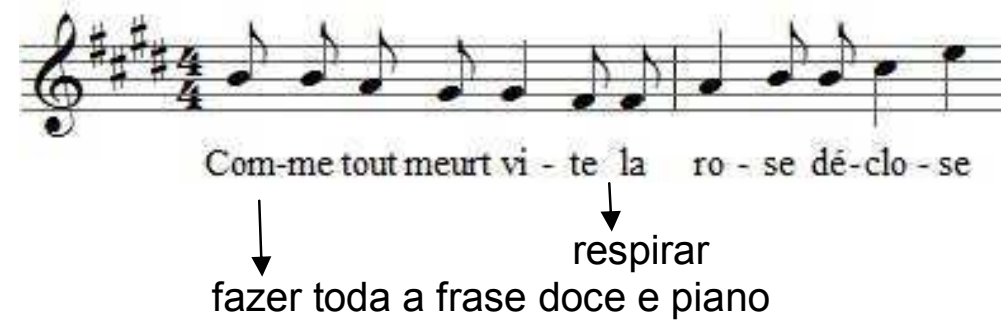




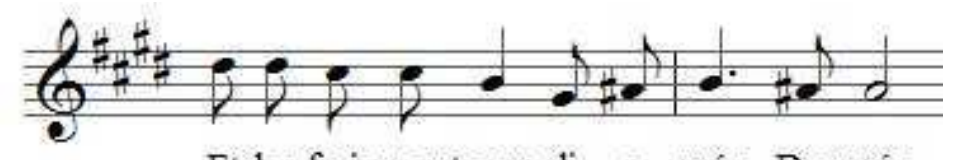

Et les frais manteaux di - a - prés Des prés

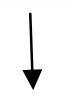

fazer uma pequena pausa sem respirar e continuar piano.
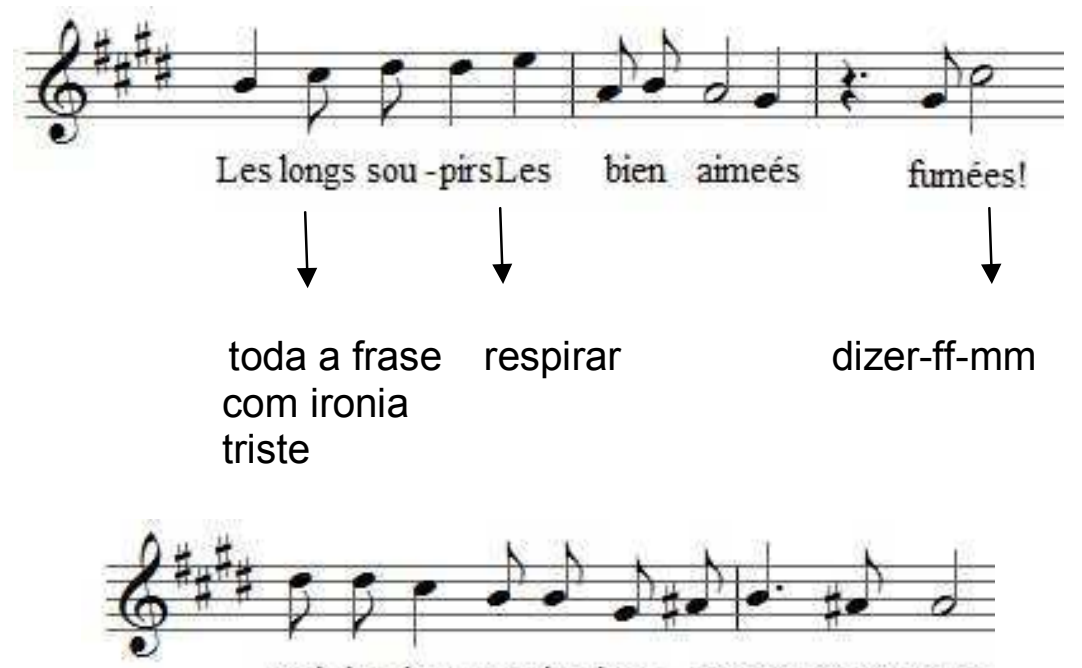

Mais he-las! Le plus long amours Sont courts
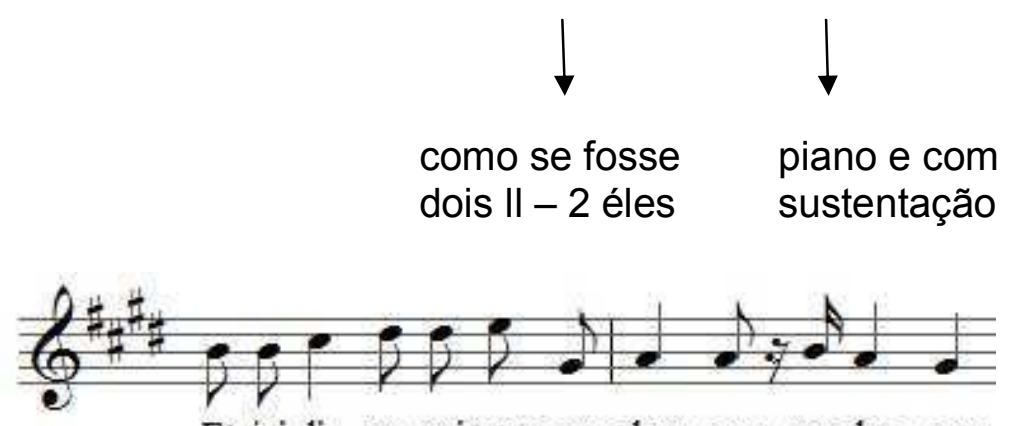

Et jai dis un quitant vous char-mes sens lar-mes

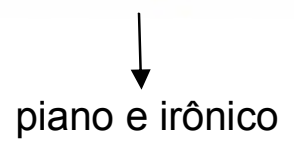

\section{Observações minhas}

(24 maio 1938)

Hoje cedo, ao fazer minha hora de vocalize notei grandes melhoras que me deixaram muito satisfeita. O exercício de terça de boca fechada está bem. Estudei como Dona Vera mandou. Fazer três a quatro vezes a nota de cima até ela sair sem precipitação de sonoridade que sempre é provocada por excesso de sopro. Depois, cantar tal qual ele é pensando nas seguintes pausas: altura, alargamento do tórax, apoio, boca na mesma abertura tanto nos agudos como nos graves, língua tranqüila, queixo flexível e quando subir lembbrar do ju. 
Quinta-feira, 26 de maio de 1938

$\left(51^{\mathrm{a}}\right.$ aula)

A aula de hoje foi na Radio Escola. Dei apenas vocalizes. Dona Vera deu-me para estudar, "Alleluia" de Mozart e "Au Loin" de Shumman.

\section{Observações minhas}

(30 maio 1938)

Fiz inegavelmente um progresso espantoso nestes quatro dias. O motivo foi isso "estudei com consciência". Preparei "Au dês dês longes" de Lulli e três magníficas surpresas; "Alleluia" "Au Lou" e "Clair de lunne" sendo que "Alleluia" vou dar pela primeira vez e já inteirinha de cor.

Quinta-feira, 2 de junho de 1938

$\left(52^{\mathrm{a}}\right.$ aula $)$

A lição foi boa, poderia ter sido melhor se não fosse eu estar muito cansada com mudança de casa.

Au Loin

$\left(1.815^{+}\right.$

(Shumman)

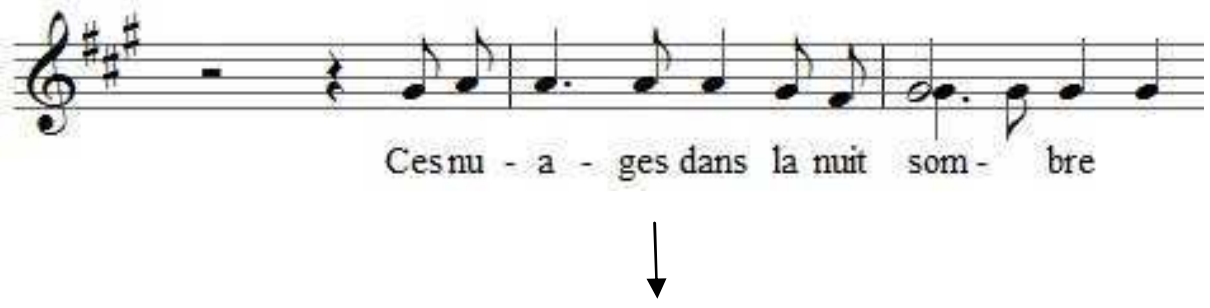

toda esta frase deve ser muito plana, muito calma, muito nostálgica.

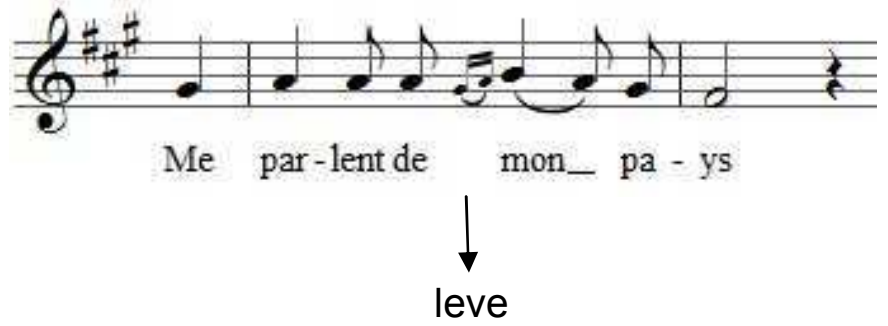




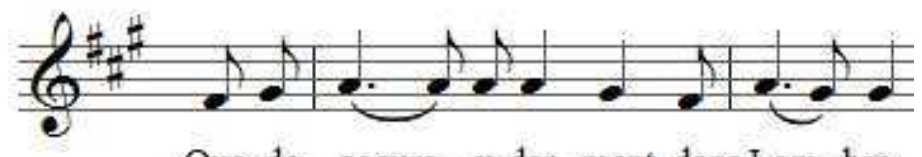

Que de coeurs - y dor-ment dans Lom-bre

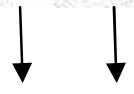

fazer a ligação sy $\quad$ o

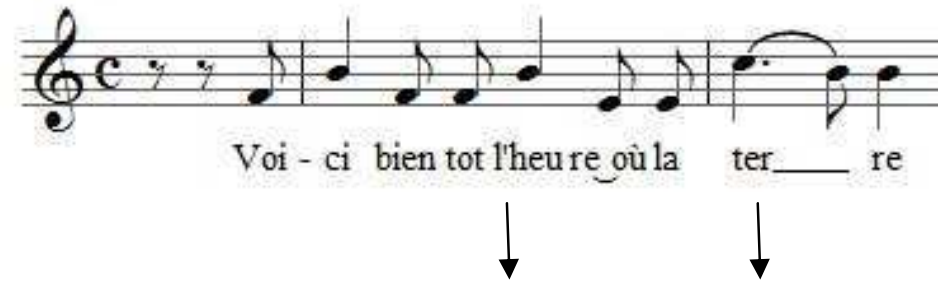

altura $\quad 0$
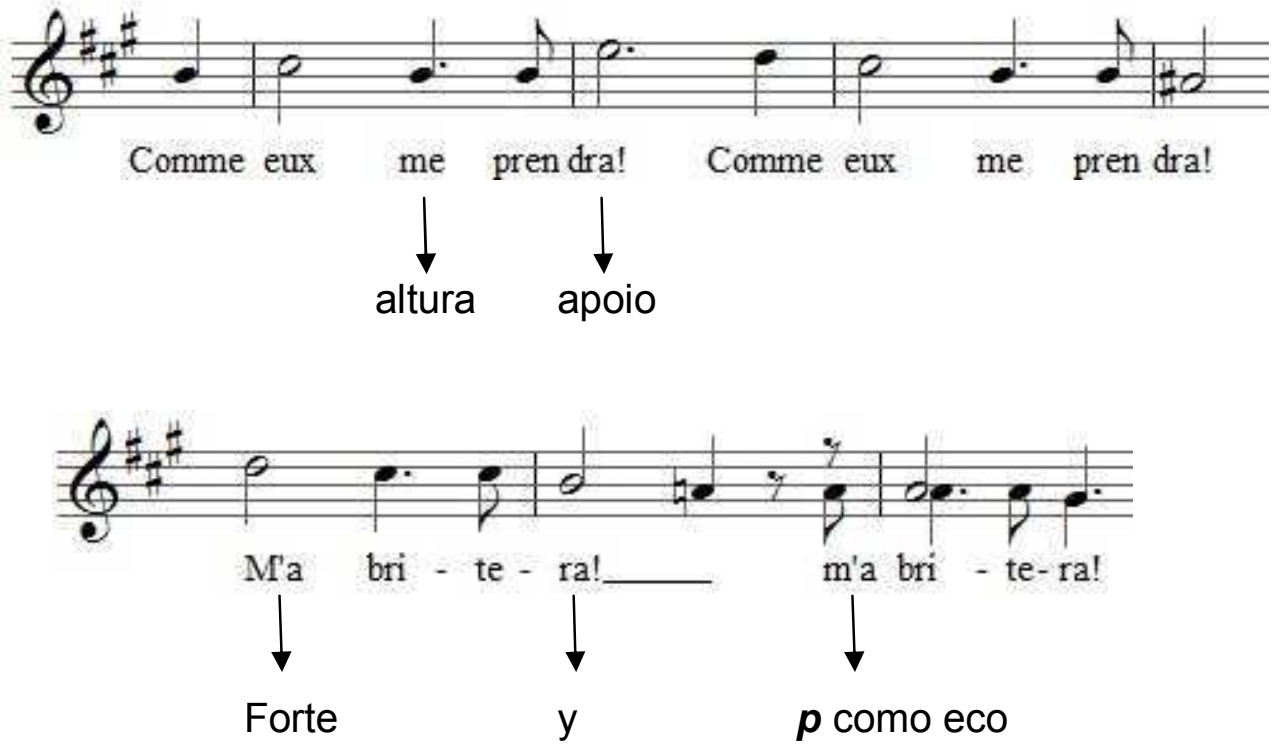

Alleluia

(Mozart)

$(1.756+1791)$

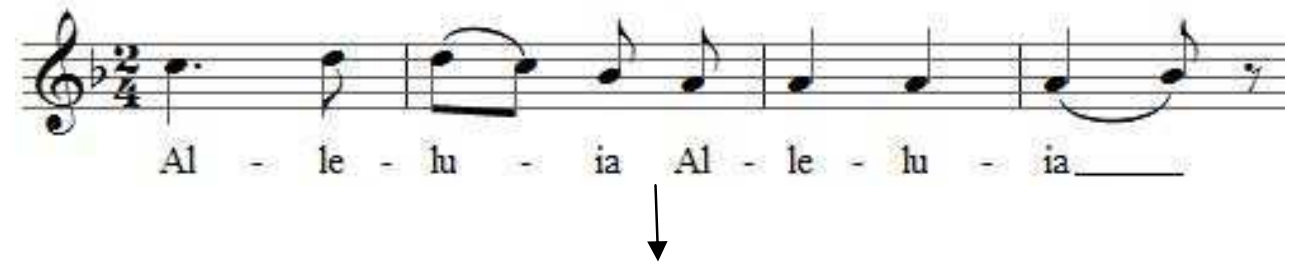

cortar sem respiração 


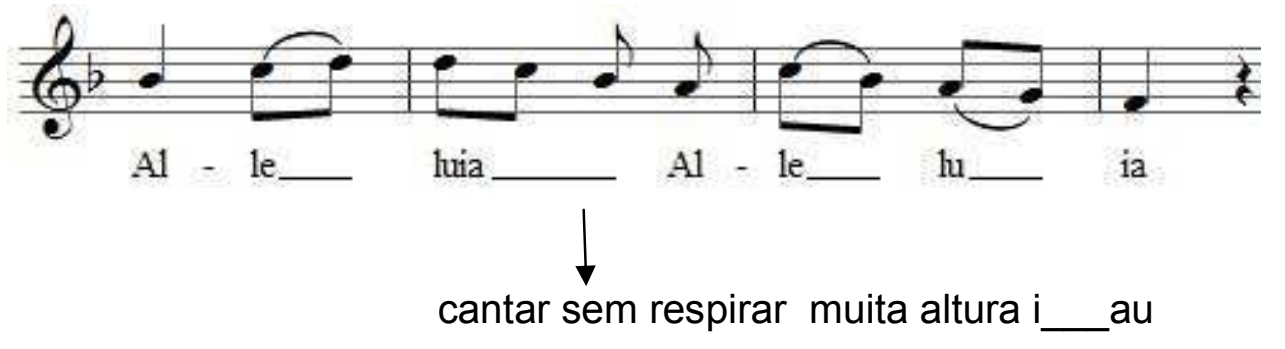

As vocalizes precisam ser maleáveis e muito leves.

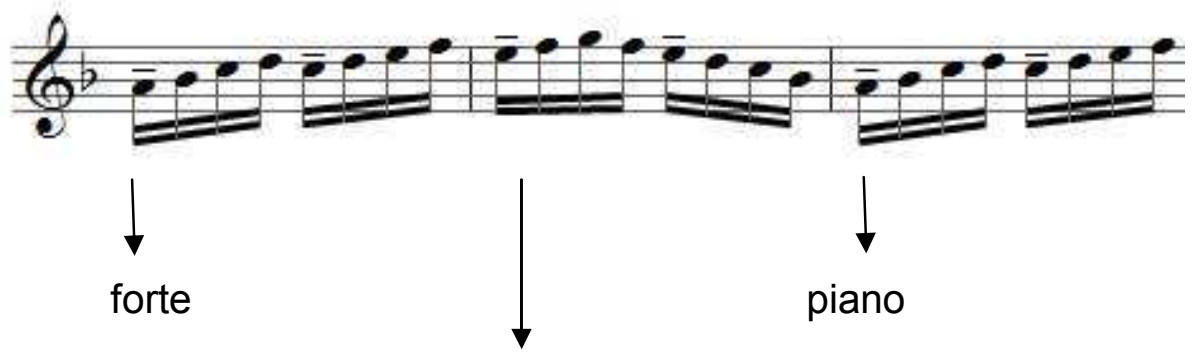

Marcar de quatro em quatro. Fazer leve sentindo ye-ye-ye afim do queixo ficar mole. Dessa forma as vocalizes ficarão clars e soltas e sem excesso de sopro.

Para as principiantes Dona Vera passou também a "Alleluia" e "Revenez amour" de Lulli. Passou a escala Lili Lehmamm com "Fidelité", "Alleluia" e "Ilusion".

Clair de lune

(J. Fauré)

$(1.845+$

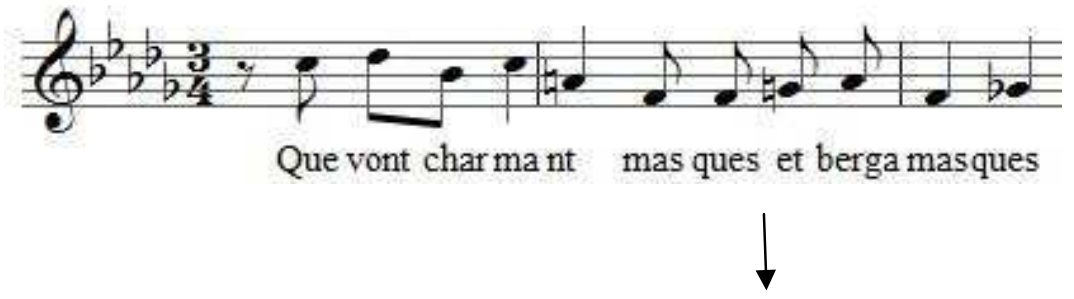

ligar zet

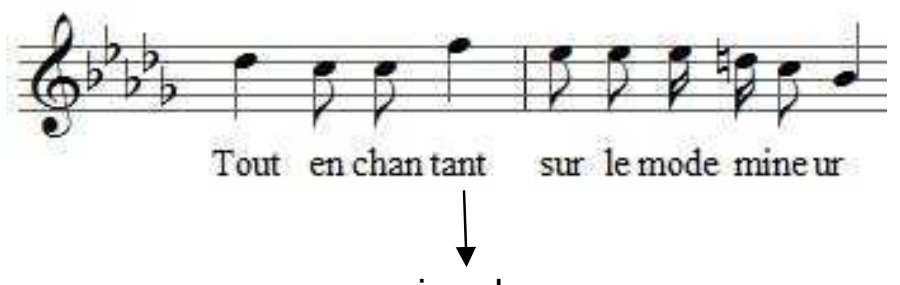

apoio e leve 


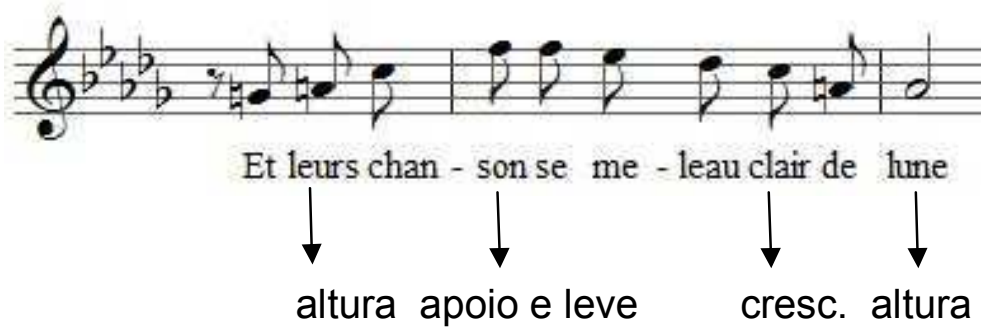

Dona Vera acha que eu preciso descascar mais a voz.

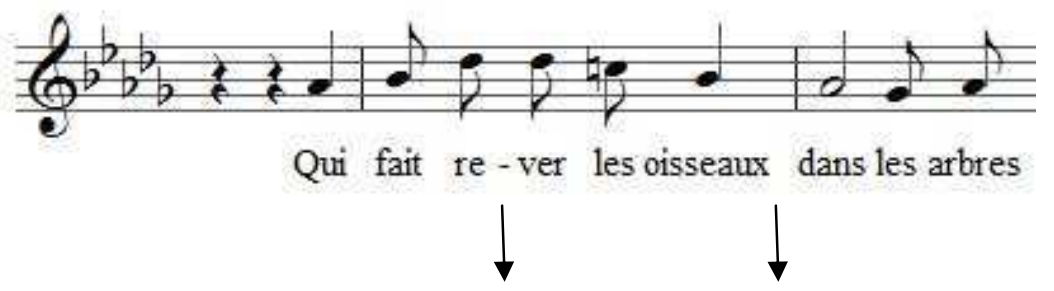

bem falado fff respirar

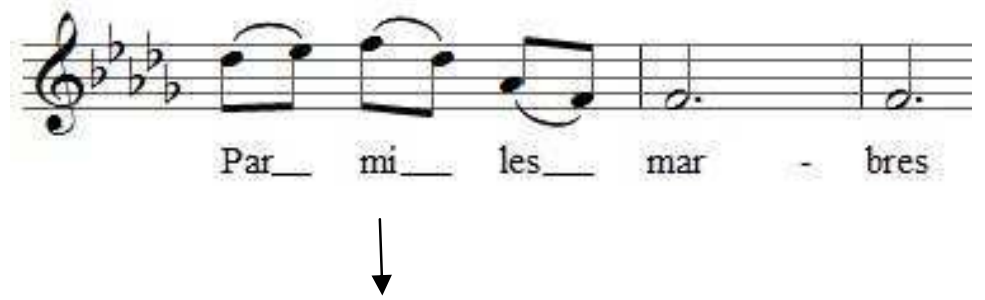

apoio e leve, irônico indiferente para o "mármore" parecer gelado e frio...

Segunda-feira, 6 de junho de 1938

$\left(53^{\mathrm{a}}\right.$ aula $)$

A lição hoje foi acompanhada pelo Salles. O "Alleluia" Dona Vera achou bem. "Au Loin" ela gostou, "Clair de lune" está mais ou menos, tenho nessa musica muito que estudar. Noto qeu dona Vera tem muita vontade que eu estude "Les Rose d'Ispahan" Vou prepará-la para a próxima aula.

Terça-feira, 7 de junho de 1938

(54 aula)

Cantei somente vocalizes. Iniciei com a escala de Lili Lehmann adotando as seguintes palavras: Illusion, fidelité, divinité, come les printemps. Quando chegar ao agitado devo 
descer três a quatro vezes - TEMPS. TEMPS. TEMPS afim de mais facilmente cantar o printemps. Fiz depois os vocalizes de Alleluia.

\section{Quinta-feira, 9 de junho de 1938}

(55 aula)

A lição de hoje para mim foi interessantíssima. Foi uma lição que me valeu por quatro, aprendi muito. Iniciei com o exercício "llusion - fidelité", etc". Nas vocalizes de "Alleluia" de Mozart Dona Vera acha que nas notas agudas eu desperdiço muito sopro. Devo cantar com mais altura, mais leveza e assim o sopro se equilibra. Depois dona Vera me fez cantar a frase do "Toujours" de Fauré: "comme le printemps". Iniciei três tons abaixo até chegar a si natural agudo voltando depois ao tom em que a música é escrita. Dona Vera passou-me hoje um novo exercício:

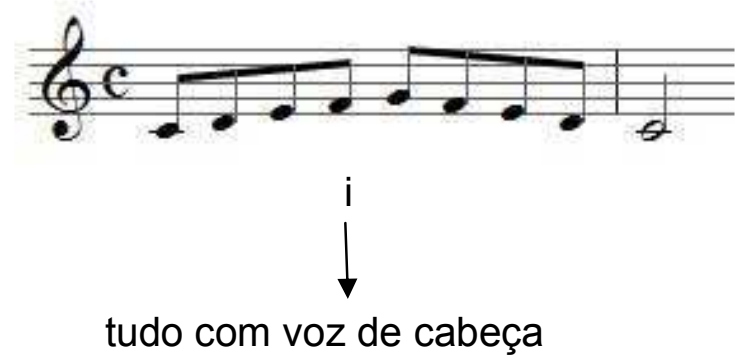

\section{Segunda-feira, 13 de junho de 1938}

(56 aula)

Hoje foi a última aula deste primeiro semestre. Amanhã à noite Dona Vera partirá para o Rio devendo regressar no dia 2 ou três de julho, afim de reiniciar as aulas. Na lição de hoje não fui de todo mal. Iniciei com a "Chanson du Papillon" que foi bem. Em seguida dei primeira vez "Air des Songes" de Lulli que foi muito bem só que eu preciso prestar mais atenção nas terminações das palavras como por exemplo: "oh tranquille" não fechar o e.

Cantei de "Alleluia" que foi ótimo. Preciso fazer as vocalizes mais em a eu estou fazendo muito em o. Depois dei "Au loiu de Shumman" que dona Vera gostou muito só que pediu-me que não fizesse dramático. Ela acha que eu devo iniciar saudoso e triste, depois fazer mais dramático e acabar triste. No "Clair de Lune" eu fui mais ou menos. O acompanhamento do Salles eu não ouvia de sorte que por várias vezes entrei fora de compasso. Mesmo assim dei inteirinho décor. O "Adieu" de Fauré foi bem, teria sido ótimo se o Salles me deixasse respirar e "Le Secret" foi esplêndido. 


\section{Observações minhas}

\section{2 / junho / 38}

Durante estes vinte dias não deixei totalmente de estudar salvo os oito dias em que estive resfriada. Hoje reiniciei os estudos acompanhada por Isabel Mourão. Achei-me muito melhor nas vocalizes de "Chanson du Papillon" e de "Alleluia". As escalas estão mais livres, mais leves e com menos sopro. Em tudo eu progredi; no "Voi che sapete", no "Non so piu", no "Au loin", "Les berceaux", "Rencontre" e "Toujours", no "Adieu" não tanto. A nota final já esteve bem melhor e agora estou fazendo soprado. Achei horrível, péssima "Quella fiamma" preciso repassá-la várias vezes pacientemente. "Air des Songes" também meio ruim devido as notas de cabeça estarem sopradas.

\section{Terça-feira, 5 de julho de 1938}

$\left(57^{\mathrm{a}}\right.$ aula)

Reiniciei hoje as minhas lições que tanto prazer me causam. Dei apenas vocalizes e não fui de todo mal.

\section{Quinta-feira, 7 de julho de 1939}

Dona Vera hoje estava um anjo cheio de exigências. Cantei acompanhada por Isabel. Iniciei com o "Voi che sapete" bem a contra gosto meu pois não acho que seja uma música para começar uma aula.

A primeira vez saiu horrível muito soprado, a segunda foi melhor, embora fosse péssima. Dona Vera aconselhou-me o seguinte: quando começar uma música, caso a gente se sinta meio nervosa ou com o coração batendo, devemos iniciá-la com bastante altura até meio nasal.

Voi che sapete
$(1.756+1791)$
(Mozart)

Fazer toda a música com a boca mais flexível e mais aspirado.

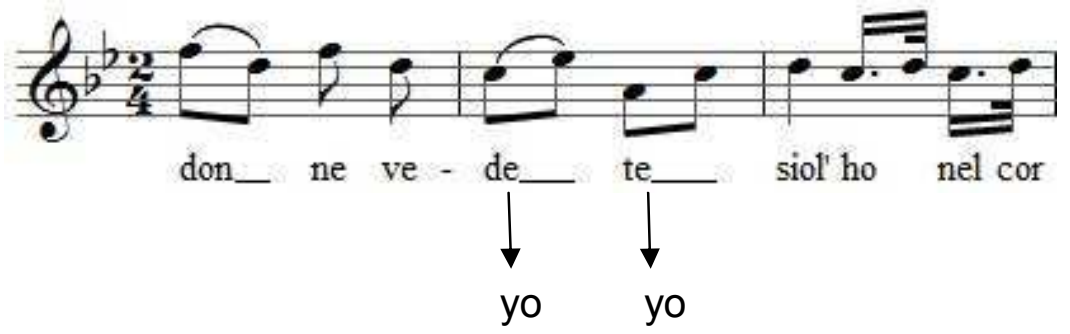




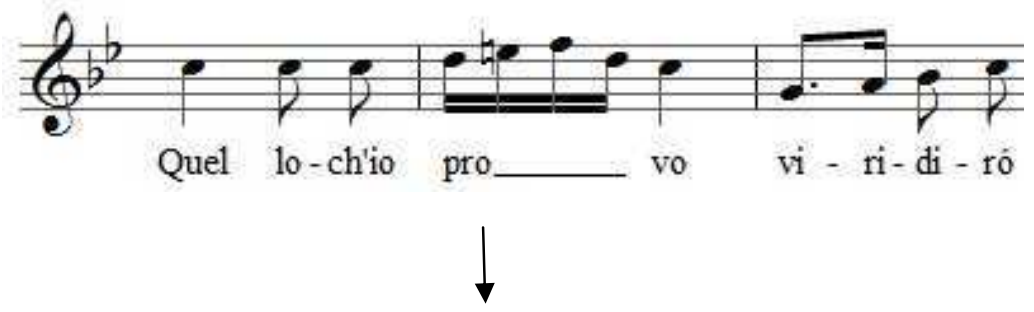

toda a frase bem piano

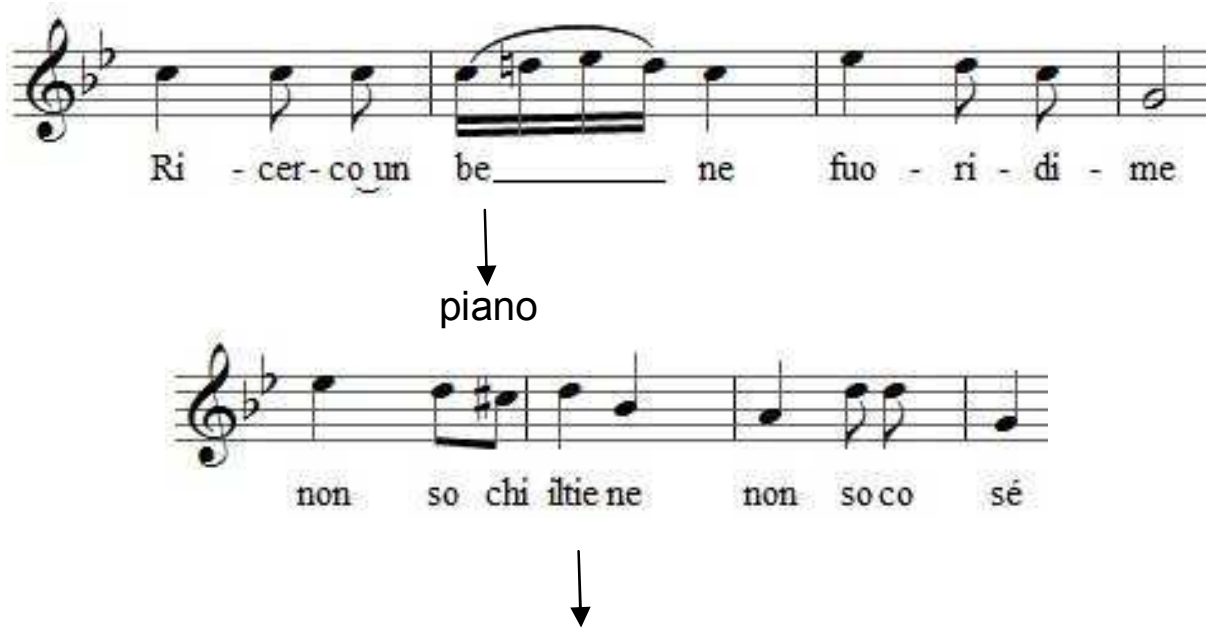

fazer as notas assinaladas bem sataccatas.

Na música seguinte notei também algumas dificuldades.

Non so più coso sou

(1756+1791) (Mozart)
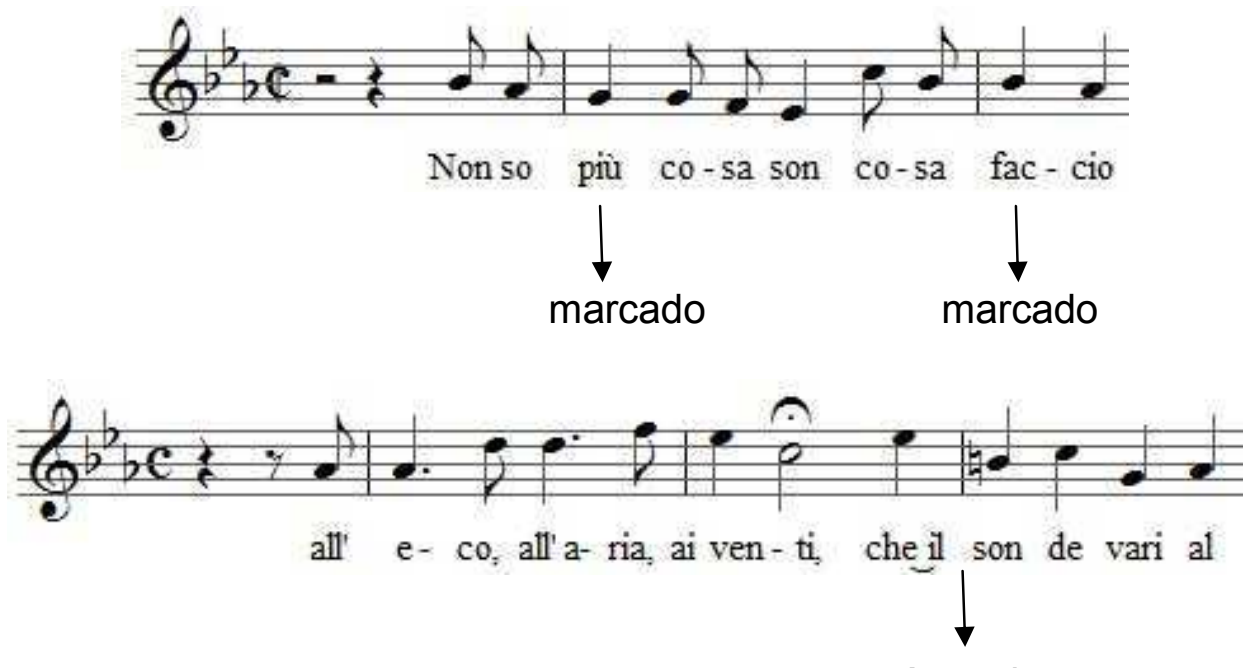

uma só respiração 
Cantei depois o Rencontre e o Toujour de Fauré que Dona Vera gostou muito, pouco teve a corrigir, o sopro está equilibrado e as consoantes mais leves.

\section{Segunda-feira, 11 de julho de 1938}

(59a aula)

Dei apenas vocalizes e o "Lasciatemi morire" de Monteverdi cuja musica vou apenas exercitar como estudo pois para repertório não gosto.

As vocalizes foram ótimas.

Lasciatemi morire

$(1.157+1643)$ (Monteverdi)
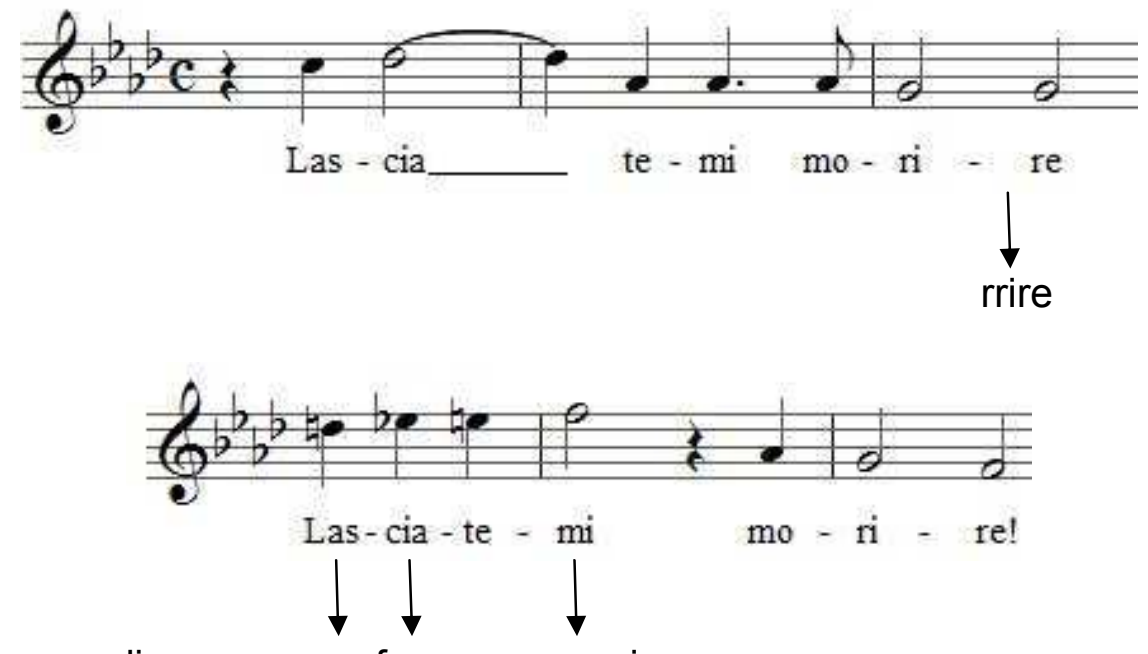

dizer como se fosse au - au iu

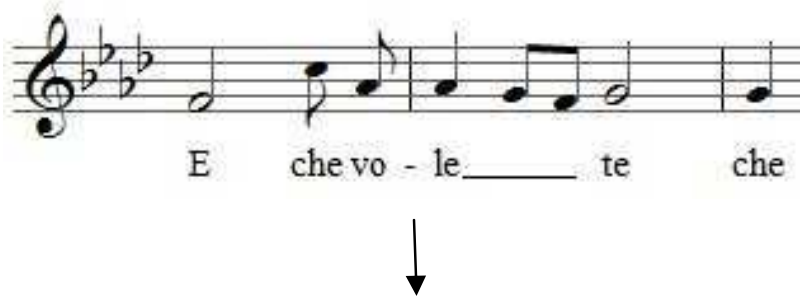

fazer toda esta frase bem ligada como um violoncelo.

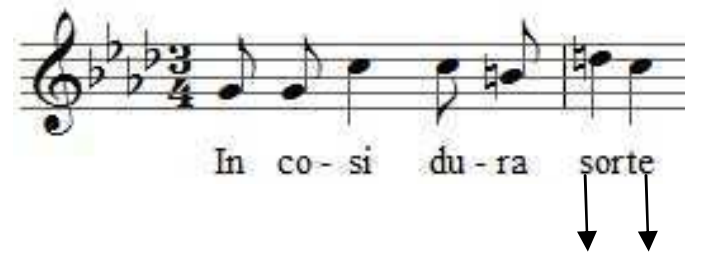

como se fossem dois esses leve 
Sexta-feira, 15 de julho de 1938

$\left(60^{\mathrm{a}}\right.$ aula)

Passei hoje para o outro curso onde encontrei um ambiente muito simpático. Foram as seguintes as explicações de Dona Vera.

Non so più cosa son

$(1.756+1791) \quad$ (Mozart)

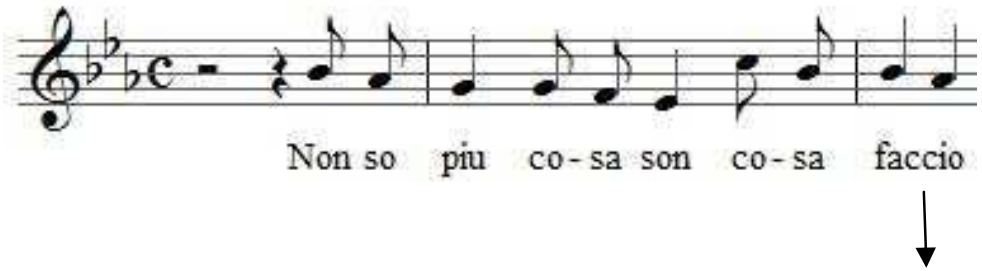

fazer bem acentuadas as letras dobradas.

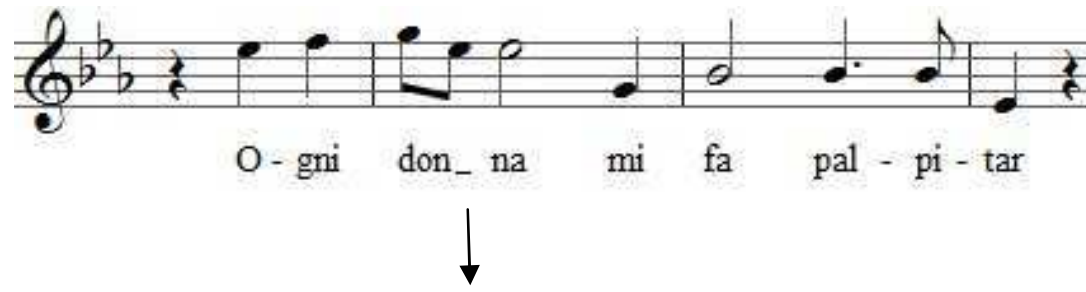

$1^{\mathrm{a}}$ vez forte e $2^{\mathrm{a}}$ piano e leve

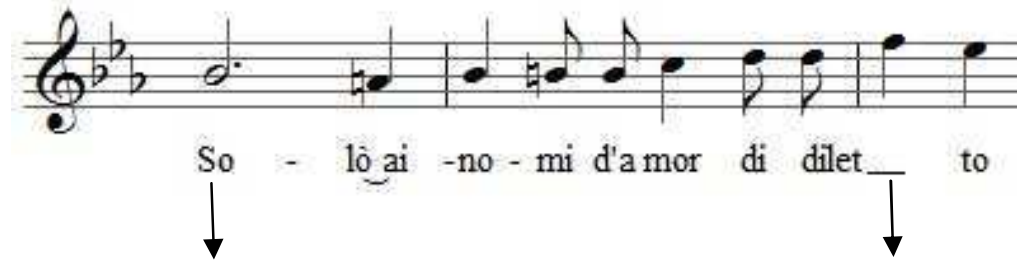

iniciar piano e aumentar. Acentuar bem os $2 \mathrm{tt}$.

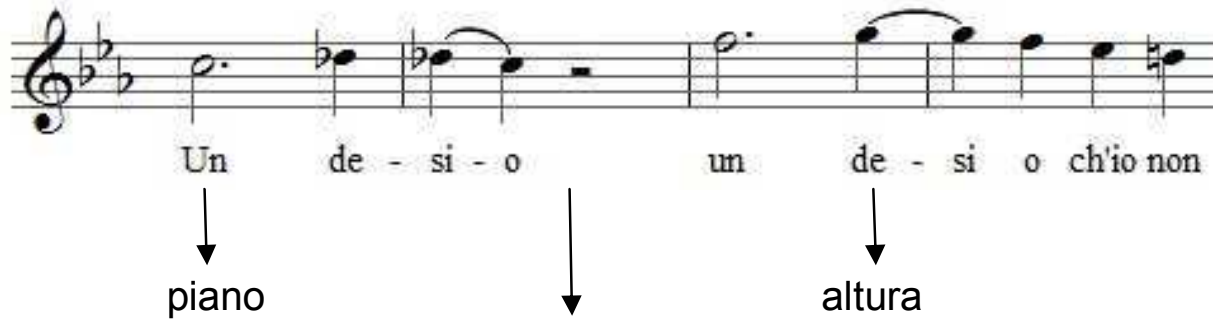

toda a frase leve e com pouco sopro 

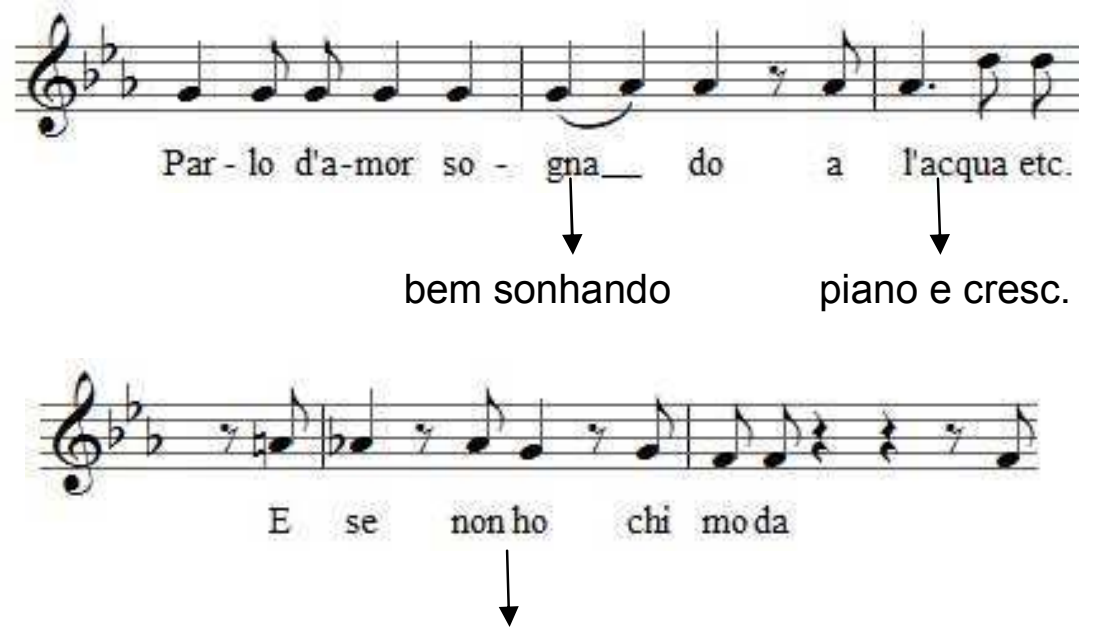

fazer bem as pausas, mostrar-se meio abstrata como quem não sabe o que fazer.

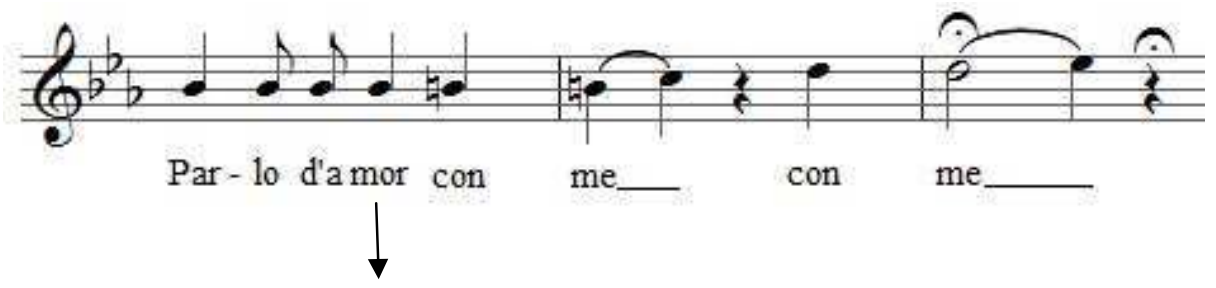

como quem tivesse encontrado uma resolução

O Recontre de Fauré Dona Vera quer ouvir novamente na próxima aula; mais tranqüilo, menos apaixonado e mais equilibrado.

\section{Terça-feira, 19 de julho de 1938}

$\left(61^{\mathrm{a}}\right.$ aula)

A aula de hoje foi somente vocalizes. O exercício "MA-MÊ-MI-MO-UM está bem. Nesse houve muito (parece faltar uma palavra aqui) a corrigir:

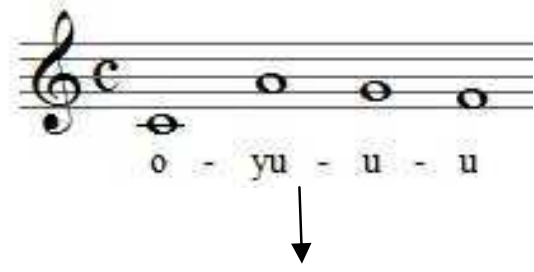

Dona Vera achou quase bom mas acha que eu passo muito rapidamente da $1^{\mathrm{a}}$ nota à segunda e por isso é que eu não consigo fazer o som bem de cabeça. Disse-me o 
seguinte: "para este exercício ser bem calado e não haver chiado, precisamos colocar muito bem a primeira nota, não deixar o queixo ir para frente, recuar a língua, pouco sopro, muita altura. Devemos até depois da nota aguda mexer com a língua como se essa fosse guiar o som. E só assim ficará perfeito pois com tudo isso serão desmanchadas todas as contrações tornando o som límpido e bem de cabeça."

\section{Sexta-feira, 22 de julho de 1938}

(62 aula)

Minha lição foi má. Cantei mal por estar naqueles dias de pouca vontade de cantar devido a uma grande e profunda tristeza que está em minha alma. Há uma semana estou me sentindo estacionada no estudo de canto. Tenho progredido pouquíssimo talvez eu precise estudar mais. Com tão boa vontade estudei o "Non so piu cosa son" de Mozart, esforcei-me o mais que pude, no entanto meus esforços foram inúteis porque está péssimo. Dona Vera não gostou pela primeira vez ela disse essa frase: esta música não está bem. Ela achou um turbilhão de defeitos. O "Recontre" de Fauré está bem como interpretação, o "Toujours" idem. No "Clair de lune", embora eu esteja bem, Dona Vera quer que eu cante mais claro, com a voz "mais descascada."

\section{Terça-feira, 26 de julho de 1938}

$\left(63^{\mathrm{a}}\right.$ aula)

Fui bem nas vocalizes. O "Non so piu" está bem melhor comparando com as outras vezes estava mais ritimado e com menos sopro. Dei pela primeira vez "Les Roses" d'Ispahan". Dona Vera achou soprado e esforçado; achou também falta de altura.

Les Roses d`Ispahan

(Fauré)
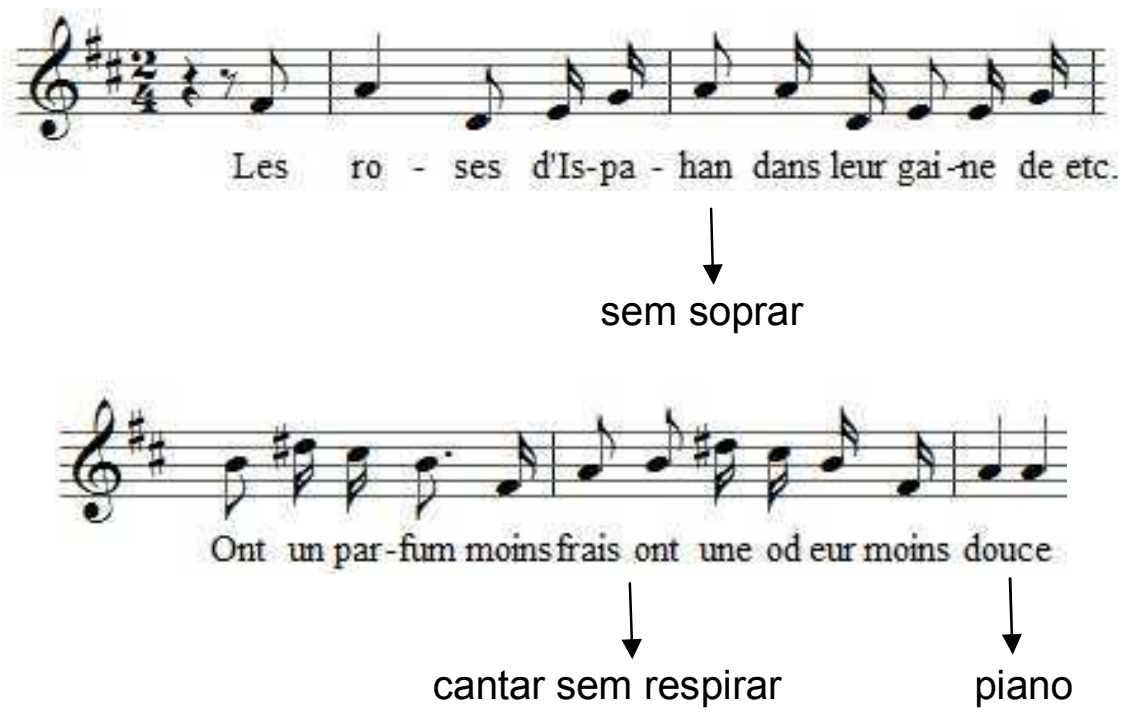


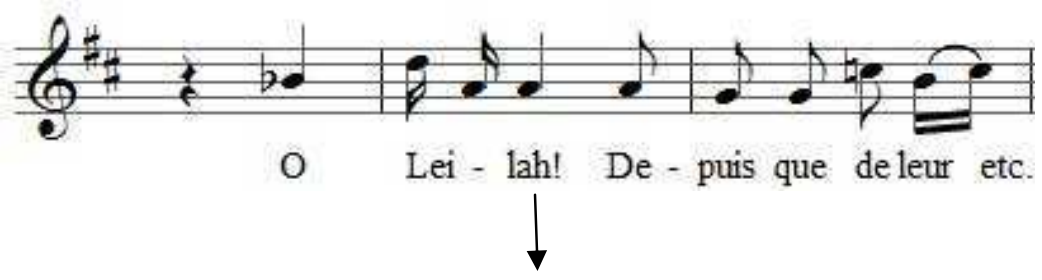

fazer bem o ponto de exclamação

\section{Sexta-feira, 29 de julho de 1938}

(64 aula)

Ando numa maré tempestuosa no meu estudo de canto. Tenho impressão de estar estacionada, não vou atrás também não caminho um passo. As três músicas que estudei ultimamente tem sido muito rebeldes não me auxiliam a progredir. São elas: "Voi che sapete", "Non so piu" e "Les Roses d'Ispahan". Para mim é dificílimo, complicadíssimo cantar uma música que no ré fa e mi agudos. Tornam-se mais fáceis essas notas quando eu as posso emitir com sopro e alargamento. Mas, nota de cabeça, é um caso serio! Ando péssima, ou alguém me correu "peso" ou não sei estudar direito. Se eu continuar nesse passo de "carro de boi" é melhor desistir. Em geral todas as minhas ambições vão por água abaixo e não me causará surpresa se também o ideal pela arte, apague-se um dia. Já estou habituada com as ruínas dos meus sonhos.

Voi che sapete

\section{$(1.756+1791) \quad$ (Mozart)}
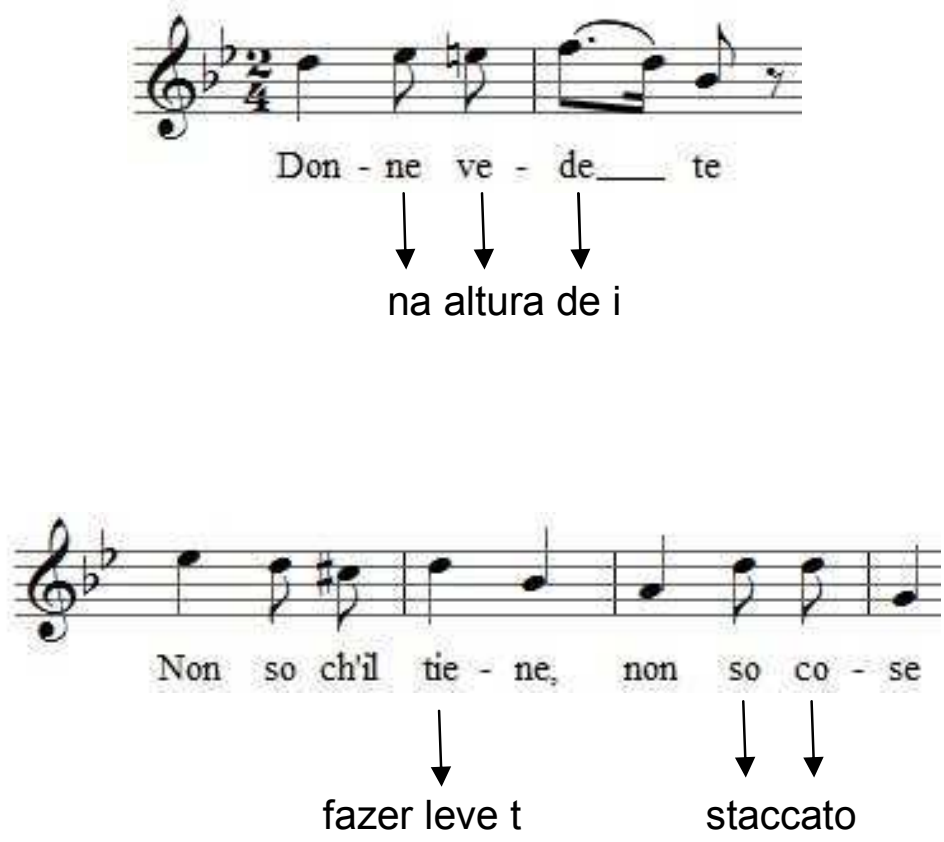


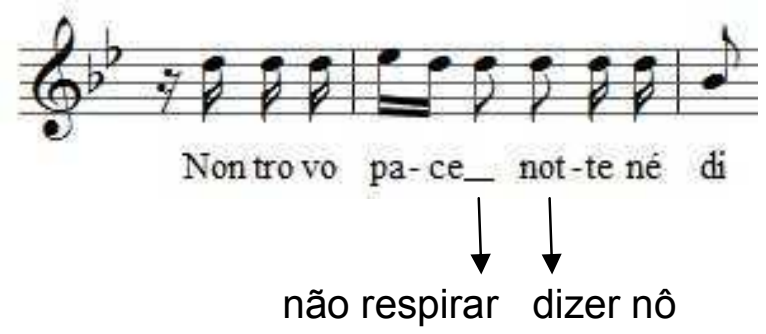

Os graves Dona Vera achou ótimos.

Les Roses d’Ispahan

$(1845+\quad)$

(Fauré)
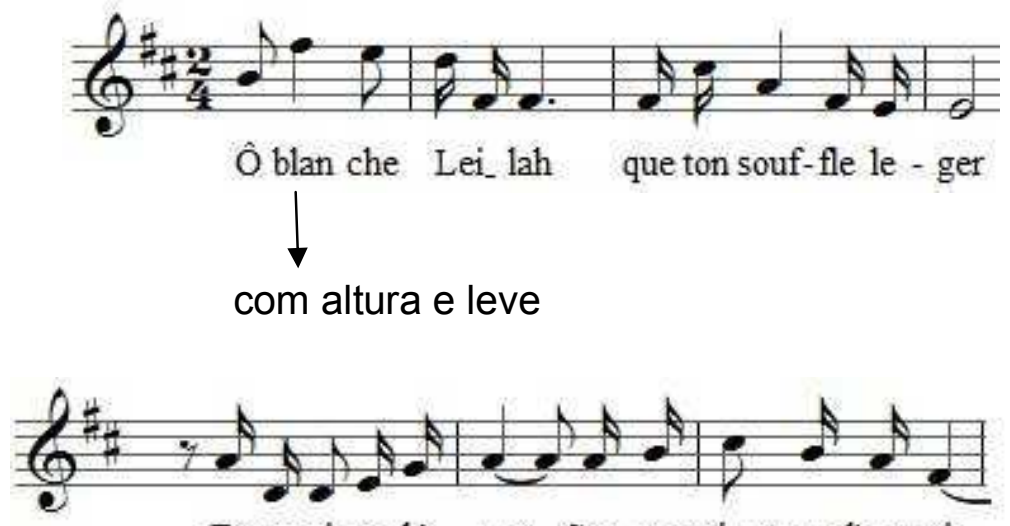

Et ton ri-re lé - ger_Son-ne mieux quel'eau vi -

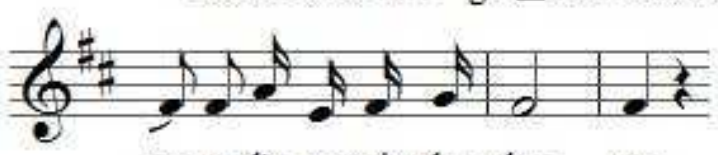

ve et d'u-ne voix plus dou - ce.

fazer essas duas frases numa só respiração. Respirar antes de "ET TON RIRE" e ir economisando sopro até "VOIX PLUS DOÚCE".

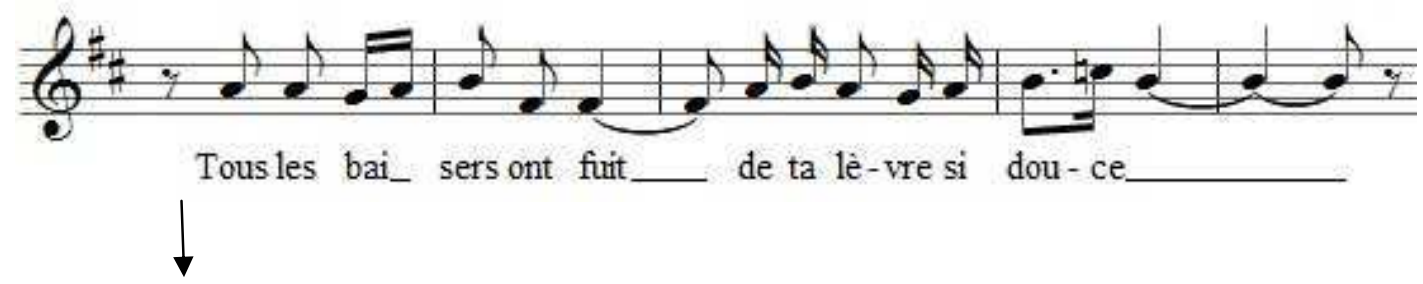

respirar e ir numa só respiração até o "douce". 


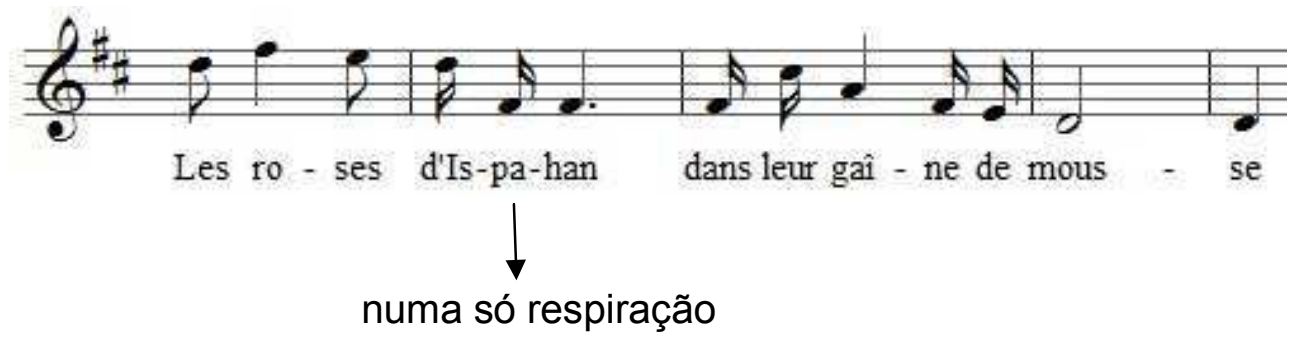

No exercício de nota de cabeça, Dona Vera me mostrou o seguinte: para se colocar bem a nota e se sentir bem, nitidamente a subida no véu palatino, devemos empregar a palavra "gong" sentir bem nasal e depois passar para a vogal u com a boca aberta. Dessa forma sente-se bem a subida do véu palatino tornando até mais fácil a execução.

\section{Terça-feira, 2 de agosto de 1938}

(65 aula)

O exercício dos grupetos foi bem. Dona Vera quer que ceda o queixo depois de cada grupo e nas notas agudas sentir ao mesmo tempo o apoio e o queixo para trás. Devo estudar os exercícios dos três piques com um dedo ou com um lápis na boca para que o queixo não vá para a frente.. No "Voi che sapete" Dona Vera achou enormes progressos como emissão achou somente falta de igualdade de som em certas notas. Ela gostou muito dos graves. Corrigiu-me o seguinte:

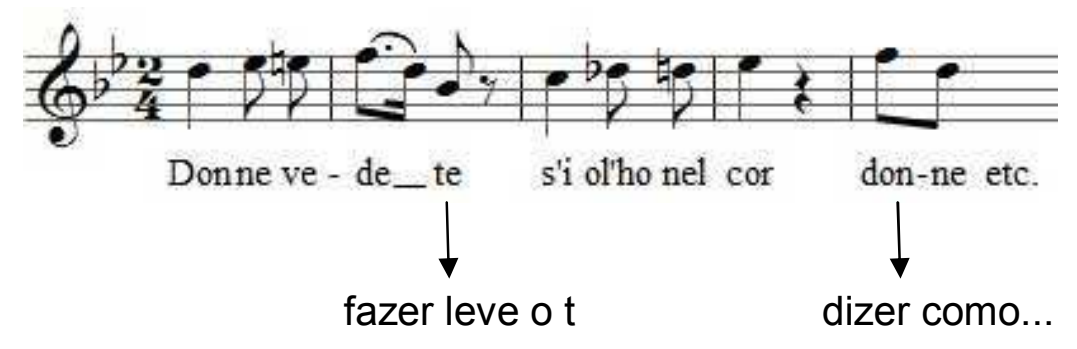

Voi che sapete

$(1.756+1.791)$

(Mozart)

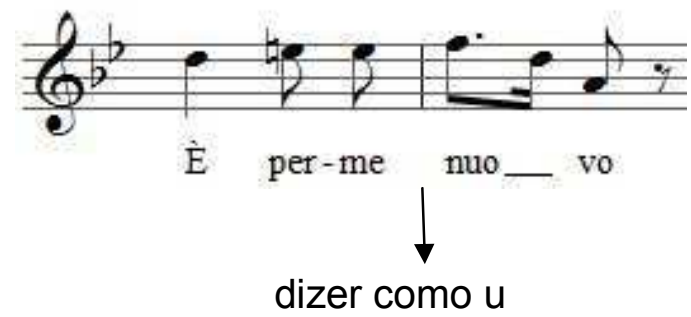



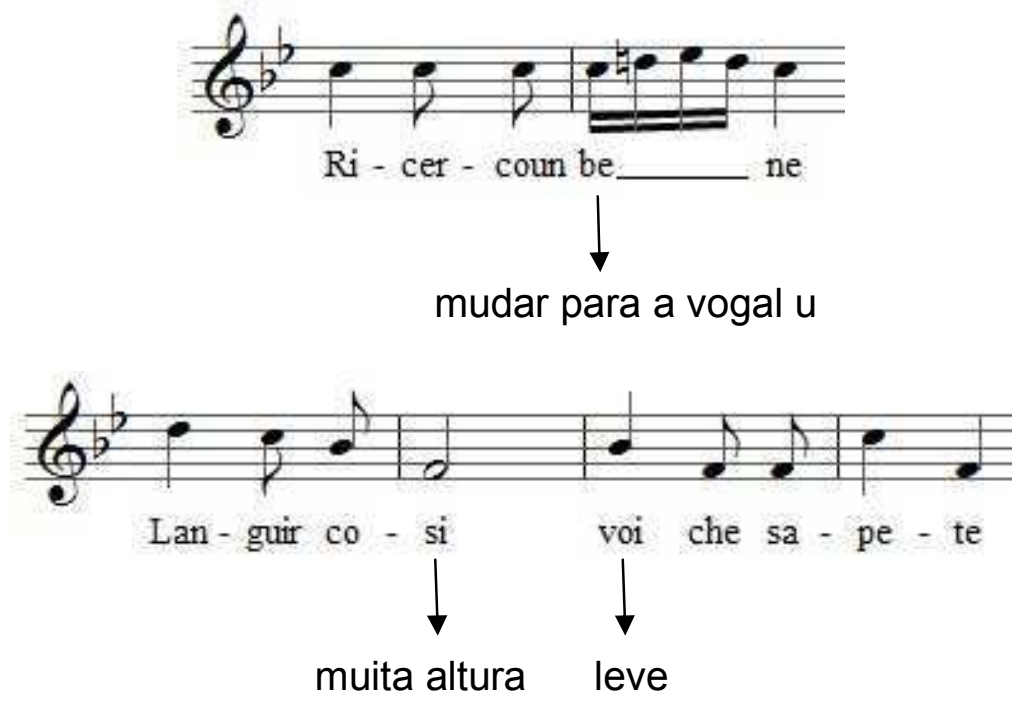

Dona Vera achou que nos e, o, eu dou muito sopro por isso eles às vezes saem trêmulos.

Em "Les roses d’Ispahan às vezes há excesso de sopro nas notas agudas.

Les roses d'Ispahan

$(1.845+$

(Fauré)
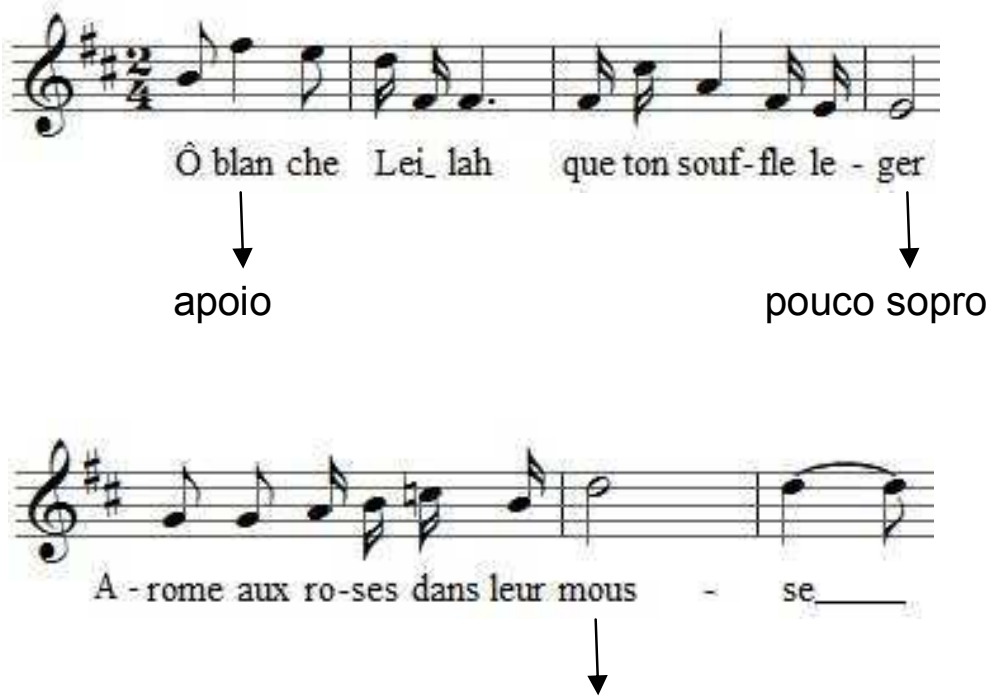

apoio dizer iuô e alargar o tórax. 


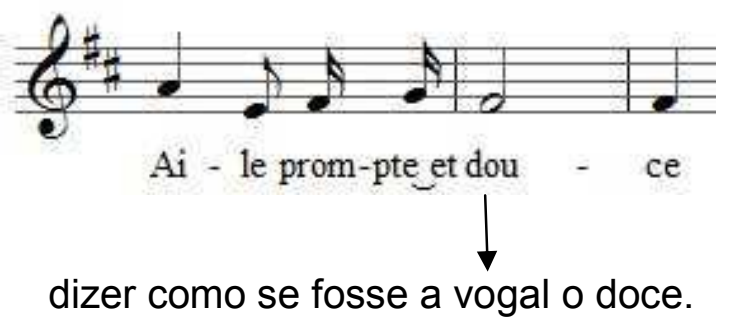

Para emitir as notas agudas, devo fazer bem ligado numa linha só.

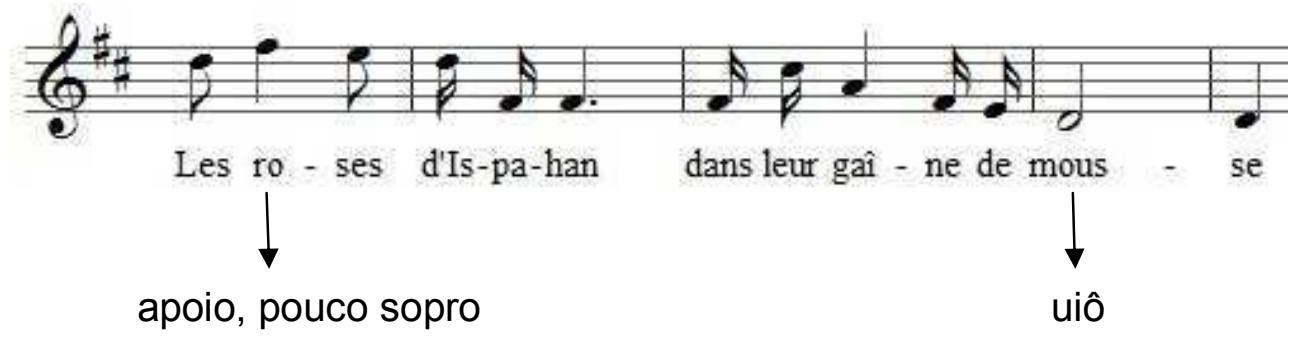

\section{Sexta-feira, 5 de agosto de 1938}

$\left(66^{\mathrm{a}}\right.$ aula)

$\mathrm{Na}$ aula de hoje senti em mim um grande progresso geral. O "Voi che sapete" está mais calmo, em estilo perfeito, enfim tal qual Dona Vera desejava que ele ficasse. Les

Roses d'Ispahan está bem. Dona Vera quer uma interpretação ais alegre, mais pura, sentindo mais o perfume "de les jasmins et l'auranger".

Terça-feira, 9 de agosto de 1938

$\left(67^{\mathrm{a}}\right.$ aula $)$

A lição de hoje foi mais longa. Dei, além das músicas, meia hor de vocalizes. Tenho que estudar para a próxima aula o seguinte exercício:

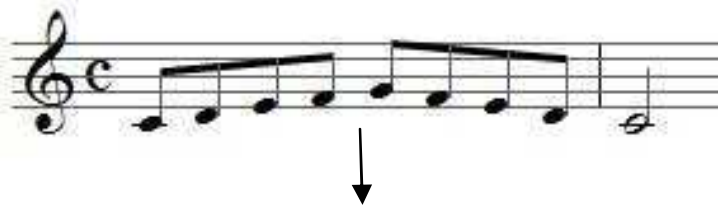

com a vogal i sendo a $1^{\mathrm{a}}$ vez forte e a $2^{\mathrm{a}}$ piano. 
Cantei "Chanson du papillon" que Dona Vera achou enormes progressos. Ela quer que eu tenha mais calma nas respirações.

Achou também que em certas vocalizes estou arrastando um pouco. Preciso iniciar mais de quatro em quatro.

Chanson du papillon

$(1.660+1.744) \quad(\ldots \ldots \ldots)$

Adieu

$(1.845+$

(Fauré)

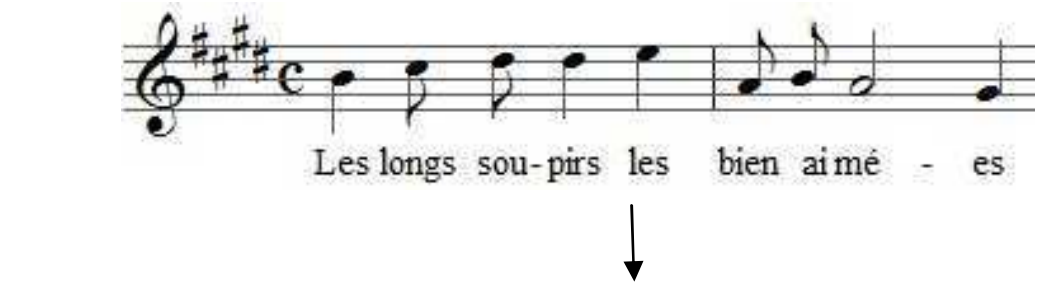

fazer portamento para dar mais um ar de quem está caçoando.

A repetição da primeira parte deve ser mais indiferente.

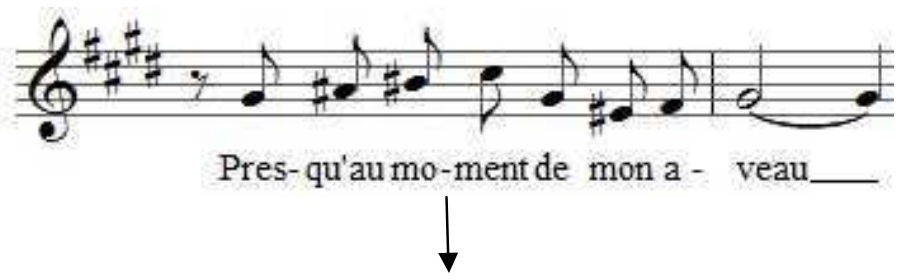

voltar ao tempo 1 lento e calmo e muita altura no Adieu!

Quarta-feira, 17 de agosto de 1938

(68 aula)

Nas vocalizes fui bem. O Apaisemetns de Beethoven Dona Vera gostou muito. Pediume apenas mais igualdade e continuidade do som. Air des Songes bem poucos defeitos. 
Air des Songes

$(1.632+1.687)$
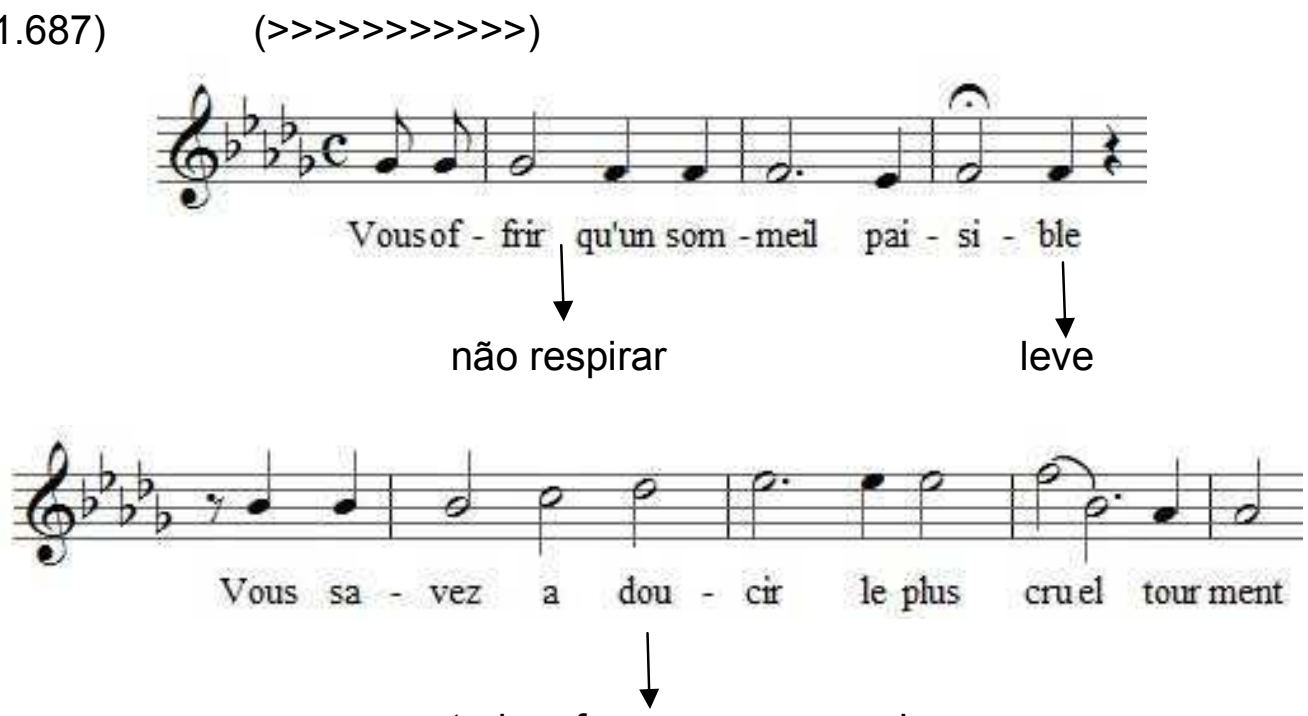

toda a frase no mesmo plano.

\section{Sexta-feira, 11 de agosto de 1938}

(69a aula)

A lição de hoje deixou radiante. Air des Songes está ótima. Automne Dona Vera achou muito bem. Nada houve a corrigir na interpretação. Só as respirações foram excessivas.

Autonne

$(1.845+\quad$ (Fauré)

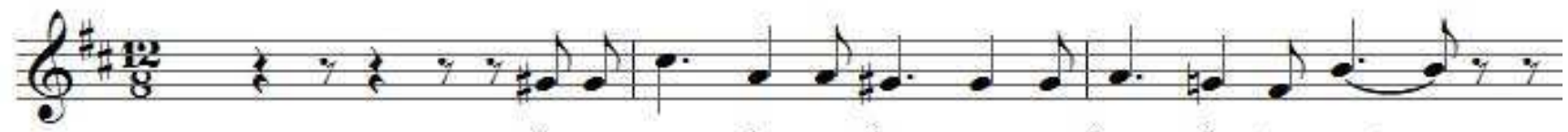

Je re-gar - de cou-ler, com-me l'eau du tor-rent__

numa só respiração

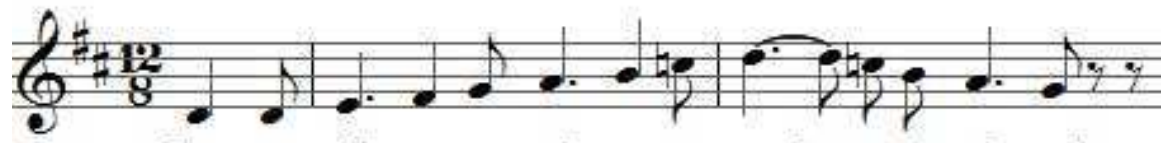

Com-me s'il se pou-vait que no- tre â_ gere-nais-se!

numa só respiração 


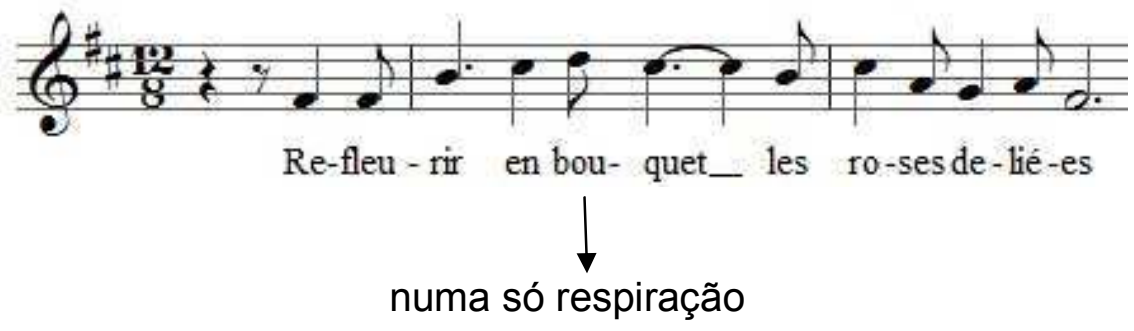

Terça-feira, 23 de agosto de 1938

(70 aula)

Dei vocalizes e fui bem. Nada tenho a anotar.

Observações minhas

(25 agosto 1938)

Ontem estudando com Isabel verifiquei em mim os seguintes defeitos:

"QUELLA FIAMMA CHE M'ACCENDE" eu já cantei melhor. Toda a música, [????] nos graves eu preciso por mais altura. Sinto-me muito aflita nas respirações, preciso mais calma para que tudo seja emitido no mesmo plano e com a mesma intensidade de sopro.

"CLAIR DE LUNE" melhorou bastante; a voz está mais igual.

"AUTOMNE" vai bem. Às vezes não consigo fazer com desenvoltura a respiração que Dona Vera quer; creio que é devido ao acompanhamento que está lento demais.

\section{Sexta-feira, 26 de agosto de 1938}

( $71^{\mathrm{a}}$ aula)

"Quella fiamma Che m'accende" vocalmente está estupenda. Dona Vera quer mais apaixonada e mais liberto. O "Sebleu crudele" só falta as apojaturas serem mais leves. Do "Au loin" Dona Vera não gostou. Achou que a voz não está no mesmo plano; que o sopro está em excesso e que há falta de mudanças de cores.

Terça-feira, 30 de agosto de 1938

(72 aula)

Não fiquei satisfeita com a lição. As vocalizes achei horríveis nesse exercício de duas oitavas. 


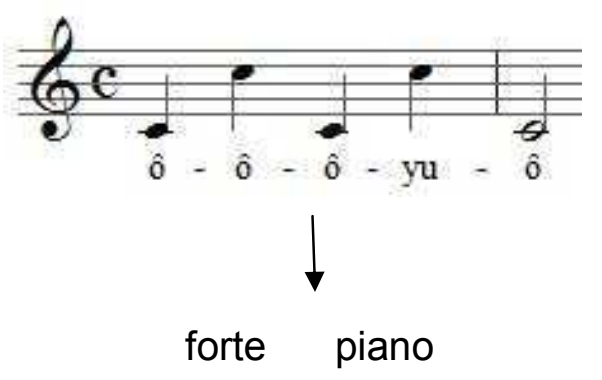

Estou dando na primeira oitava muito sopro e na nota aguda estou dizendo $A$ em vez de O. Para habituar-me a emitir com clareza devo empregar o "gong" na nota aguda sem trepidar.

Em "Au Loin" Dona Vera achou progresso na igualdade. Ela quer o seguinte:

Au Loin

$(1810+1856)$

(Schummann)
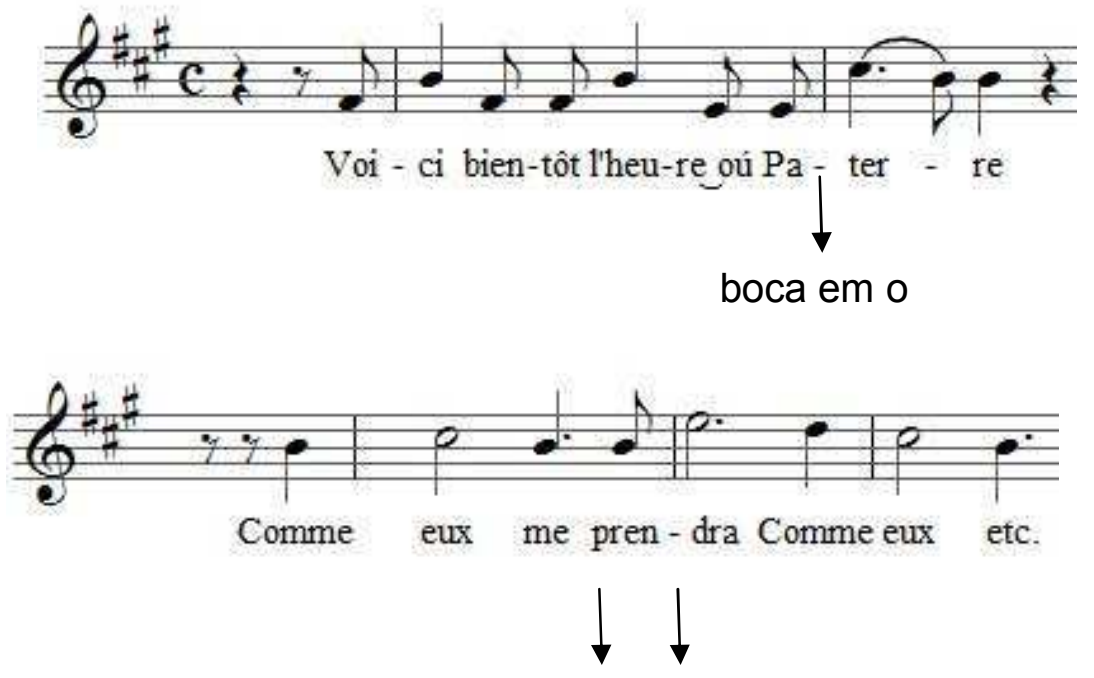

altura boca em o dizendo quase anasalado dizendo quasi au anasalado quasi. 
Clair de Lune

$(1845+\quad$ (Fauré)
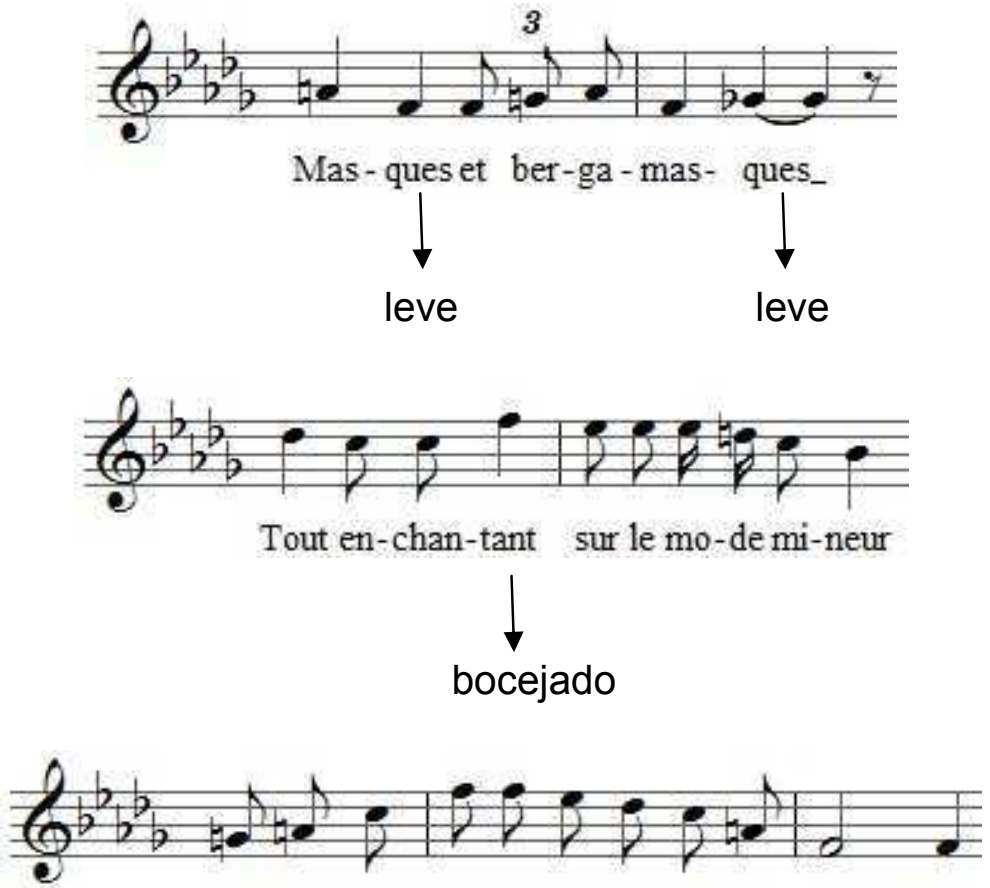

Et leur chan - son semêle au clair de lu - ne
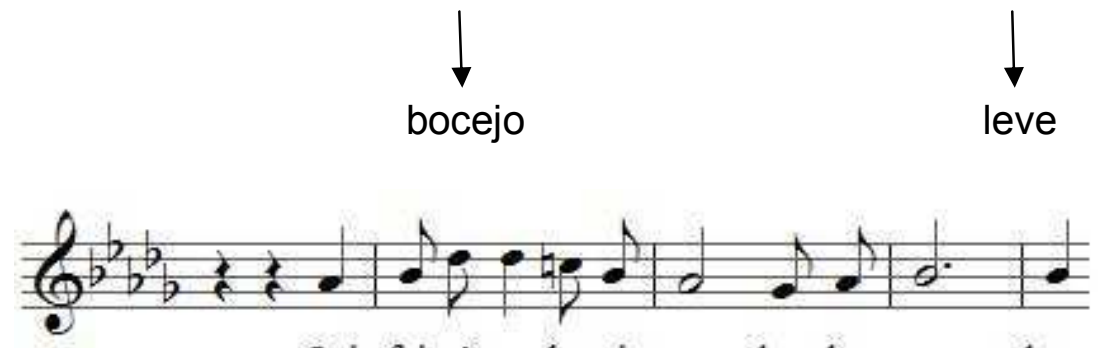

Qui faitrê-ver les oi-seaux dans les ar - bres
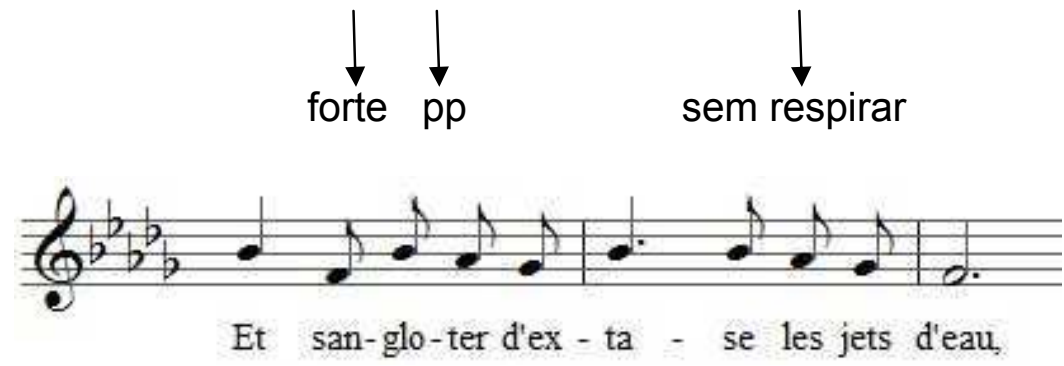

como se disesse $\mathrm{xxx}$ 


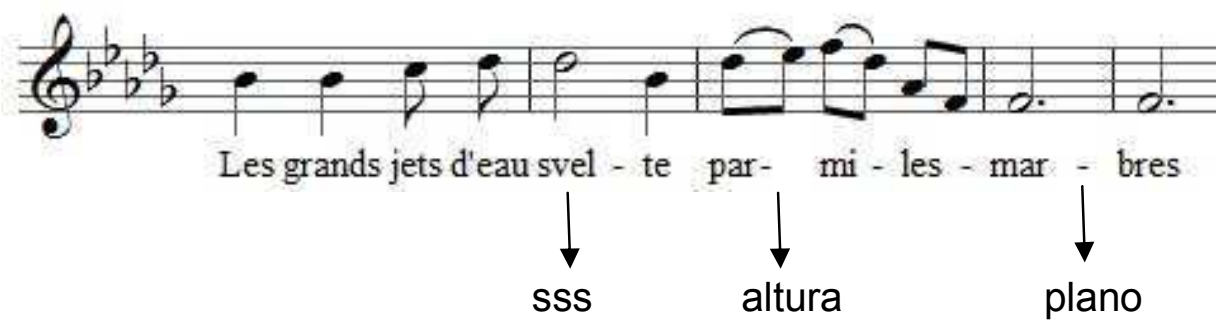

Observações minhas

(31 Agosto 1938)

Cantando hoje notei em mim grandes melhoras.

"Au loin" achei com menos sopro e com mais igualdade.

"Comme me prenda" está bem mais solto graças as explicações de Dona Vera.

"Le secret" gostei de ter conseguido fazer o "L`aube sans bruit" sem barulho e bem de cabeça,

"Alleluia" foi relativamente bem embora eu não me sinta liberta como antes nas vocalizes.

\section{Sexta-feira, 2 setembro 1938}

(73 aula)

Tudo foi bem e nada tenho a anotar.

Terça-feira, 6 setembro 1938

(não houve aula)

Sexta-feira, 9 setembro 1938

(74 aula)

A lição de hoje foi boa apesar de eu estar meio nervosa. Cantei o "Sento nel core" só que preciso ser mais instrumental com a voz calma e plana.

Terça-feira, 13 setembro 1938

(75 aula)

As vocalizes foram ótimas. No " mô-ô-ô " atingi ao do = agudo.

Comme raggio dei sol Dona Vera gostou bastante. 
Sexta-feira, 16 setembro 1938

(76 aula)

Estudados.

A minha lição não poderia ser melhor. Dona Vera achou meus graves perfeitos. Dei pela primeira vez "Prière" e "Au board de l'eau que estão muito bem estudados.

Au bord de l'eau

$(1.845+$

(Fauré)

Dona Vera gostou de maneira que estudei, achou que eu faço muito bem o ligado igual.

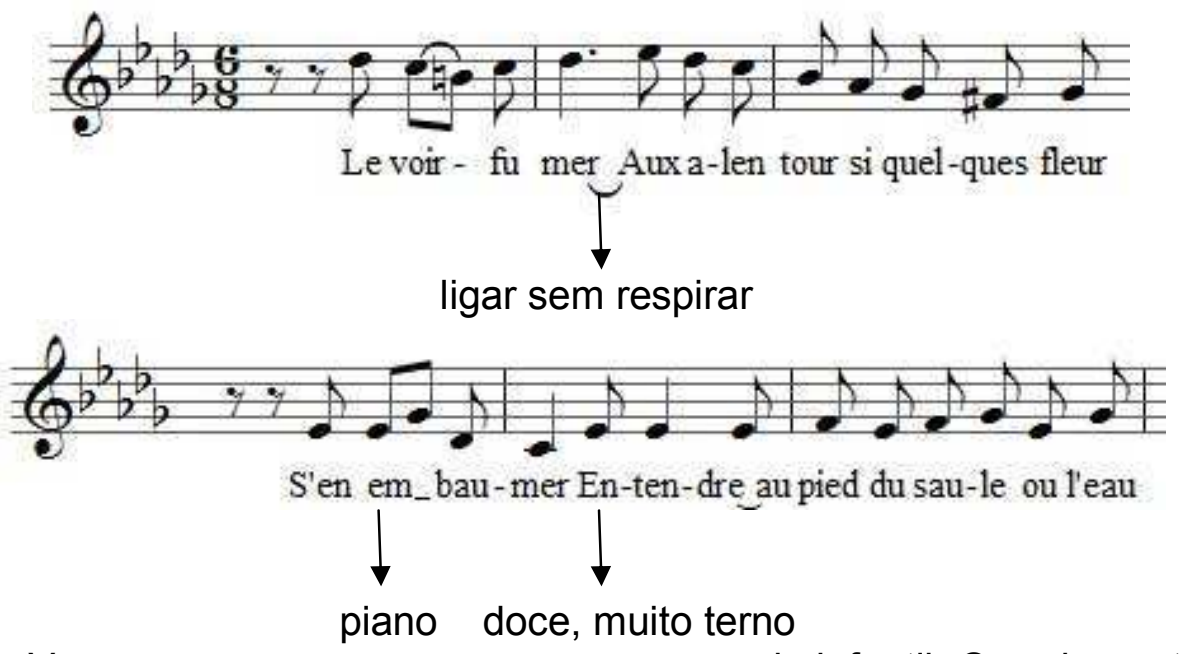

Prière. Dona Vera quer que eu comece com a voz mais infantil. $O$ andamento deve ser calmo e a voz sempre no mesmo nível.

\section{Terça-feira, 20 setembro 1938}

(77aula)

Tive hoje umas das mais belas impressões de minha vida, impressão que jamais se apagará. Ouvi dona Vera cantar Tristesse de Faure. Achei divino! Foi para mim uma verdadeira lição e agora, que vou estudar Tristesse sempre hei de lembrar-me desse momento deslumbrador. Dei hoje pela primeira vez o "Spleen" de Fauré que foi estupendo. Fui corrigida apenas no seguinte: devo fazer mais plano, nostálgico e pesado. A voz deve ser menos quente. 
Sexta-feira, 30 setembro 1938

(78 aula)

A lição de hoje correu relativamente bem. Foi para mim muito difícil mas, grande fase já venci e, se Deus quiser, hei de vencer até o fim. O exercício:

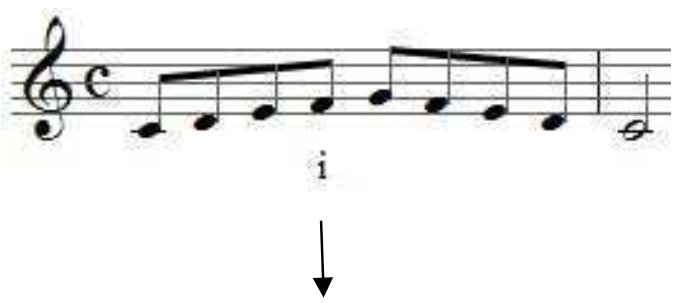

estou fazendo carregado devido ao excesso de sopro. Devo pensar mais nos j-j-j.

"D`amours eternelle" está me dando o que fazer! Felizmente já consegui decorar. Tenho esperança de que, dentro em breve, coseguirei tudo que Dona Vera corrigiu.

D`amours eternelles

$(1.833+1897) \quad$ (Brahmms)
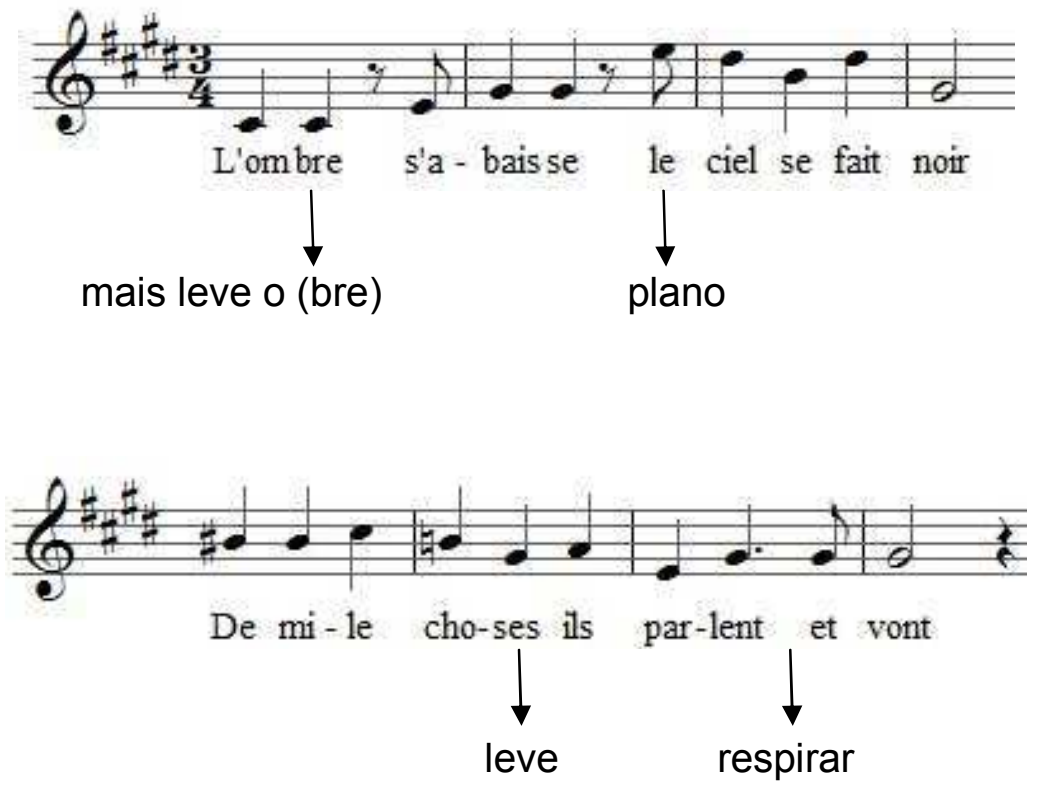


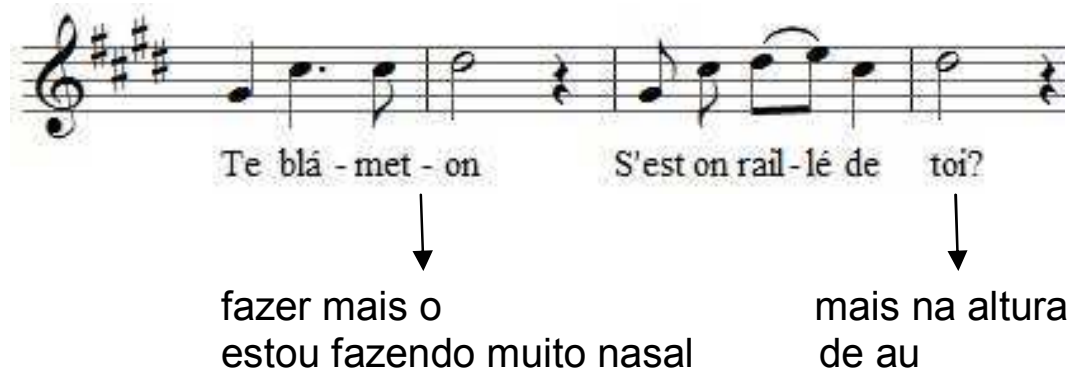

Todas as notas agudas devem ser levantadas e emitidas deslisadamente. Dei também pela primeira vez "Chanson du pecheur" que poucos erros teve.

\section{Terça-feira, 4 outubro 1938}

(79a aula)

Cantei "Chanson du pecheur" que Dona Vera acha que ficará melhor na minha voz um tom mais alto. "Damours eternelles" melhorou um pouquinho. Preciso prestar atenção nos agudos do fim. Em "Tristesse" que dei hoje pela primeira vez pouco houve a corrigir.

\section{Sexta-feira, 7 outubro 1938}

$\left(80^{\mathrm{a}}\right.$ aula $)$

Já dei de cor a Tristesse de Fauré e fui muito bem. Dona Vera quer que seja mais calmo, não depressa e sentindo bem nitidamente o compasso $6 / 8$ para não fazer valseado.

Tristesse

$(1,845+$

(Fauré)

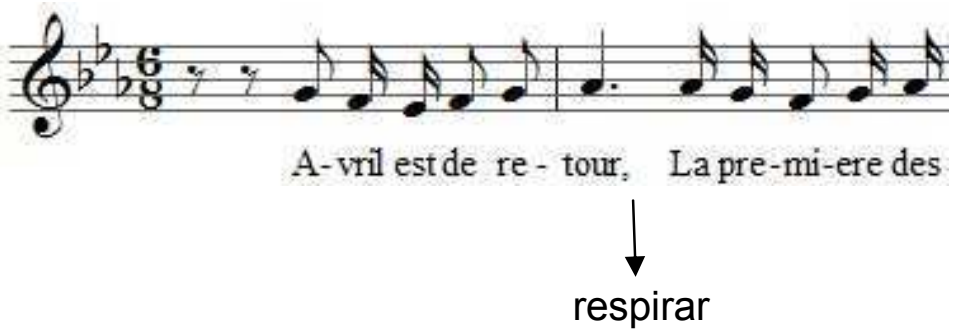

Dona Vera gostou interpretação. Ela apenas achou que no "Lês buveurs en gaité" eu fiz um pouco de drama. Deve ser mais alegre para chegar depois a "Tristesse affreuse". Não devo nunca respirar depois dos "helas". 
Chanson du pecheur $(1.845+$

(Fauré)

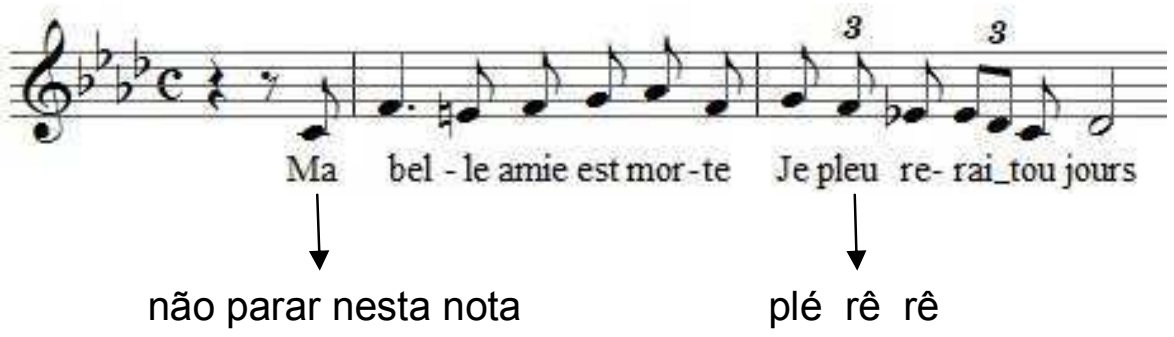

Devo cantar essa música mais como uma barcarolla; fazendo mais nublado. Certas frases devem acabar mais piano.

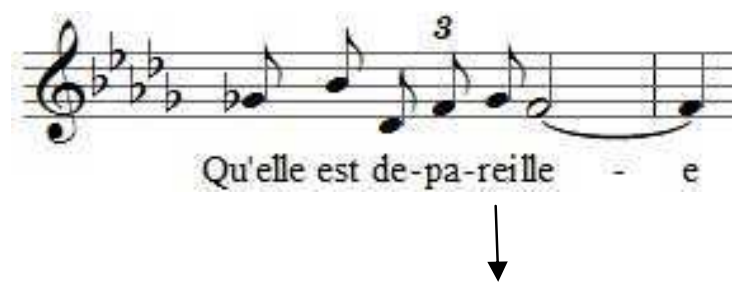

acabar a frase mais piano.

Terça-feira, 11 outubro 1938

$\left(81^{\mathrm{a}}\right.$ aula)

Fui muito bem nas vocalizes, cantei em seguida Tristesse e Chanson du percheur e desta última Dona Vera gostou muitíssimo. Os nossos quartetos de Shumman foram irradiados hoje as dez nenos $1 / 4$ pela Rádio Cruzeiro do Sul.

\section{Sexta-feira, 14 outubro 1938}

(82 aula)

Dei uma ótima lição. A vocalize de nota de cabeça foi estupenda. Dei pela primeira vez o "Ritornerai fra poco" de Hasse e está à perfeição. Nada houve a corrigir; estilo perfeito, interpretação, respiração e empostação, excelentes. Dona Vera apenas mandou-me decorá-la. Em "Dámours eternelles" melhorei consideravelmente. Os agudos saíram claros e bem emitidos.

\section{Quarta-feira, 18 (seria 19) outubro 1938}

$\left(83^{\mathrm{a}}\right.$ aula)

Nas vocalizes fui muito bem. Nada tenho que anotar. 
Sexta-feira, 21 outubro 1938

(84 aula)

Cantei o "Ritornerai fra poco" e pela primeira vez apresentei "Ai-je fait un rêve" de Schumman, sendo estas duas últimas de "Lamour d'une femme". As explicaçãoes de Dona Vera foramas seguintes:

Ritornerai fra poco
$(1.699+1783)$
(A. Hasse)

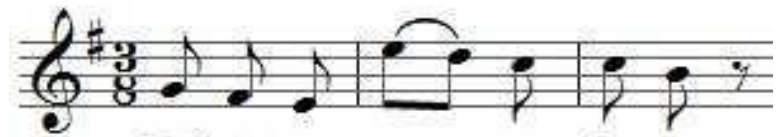

Del po -ve - ro so let - to

fazer de cima para baixo, queixo para atrás para não haver excesso de sopro.

Nada tenho a anotar a respeito desta música. Devo apenas cantá-la mais graciosa e alegre. As vocalizes bem claras e em A.

Os Schumman agradaram bastante e Dona Vera prova é que pouco foram corrigidos.

$\mathrm{Ai}$ - Je fait um rêve?

$(1815+1856) \quad$ (Schumman)

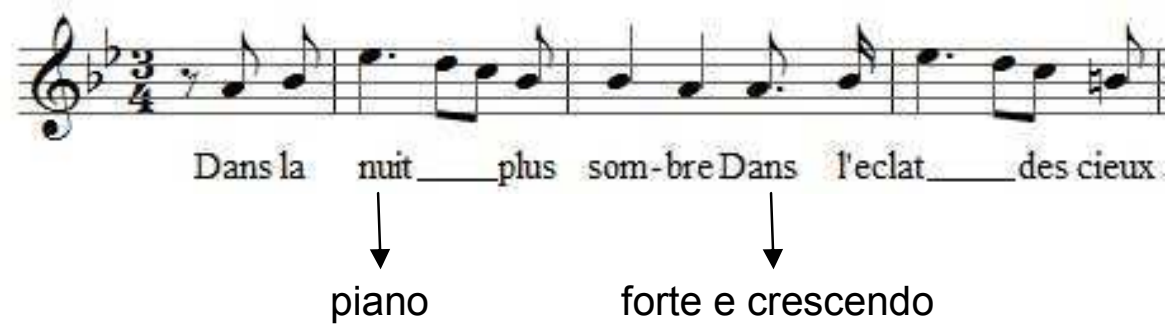

O "Noble esprit" pouco teve a corrigir. A interpretação ótima e vocalmente vai bem.

Os coros brasileiros foram irradiados hoje às nove e meia pelo Cruzeiro do Sul.

\section{Quarta-feira, 26 outubro 1938}

(85 aula)

As vocalizes estão melhores. Ganhei para estudar um exercício novo que é o seguinte: 


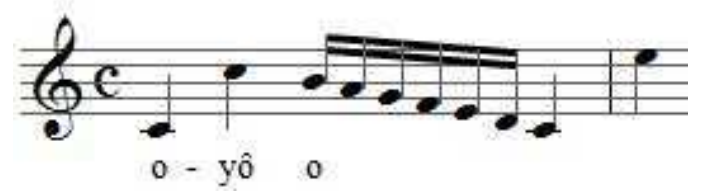

Sexta-feira, 28 outubro 1938

Irradiamos às 7 hs os coros brasileiros.

Sexta-feira, 4 novembro 1938

$\left(86^{\mathrm{a}}\right.$ aula)

Dei hoje uma aula péssima. Os agudos foram horríveis e soprados. Dona Vera mandoume estudá-los de boca fechada, pois disse que dá esplendido resultado.

Ritornerai fra poço

$(1.699+1783) \quad$ (A Hasse)

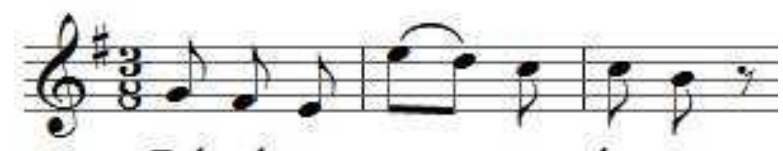

Del pol-ve - ro__ so let-to

dizer mais ou, leve e pouco sopro

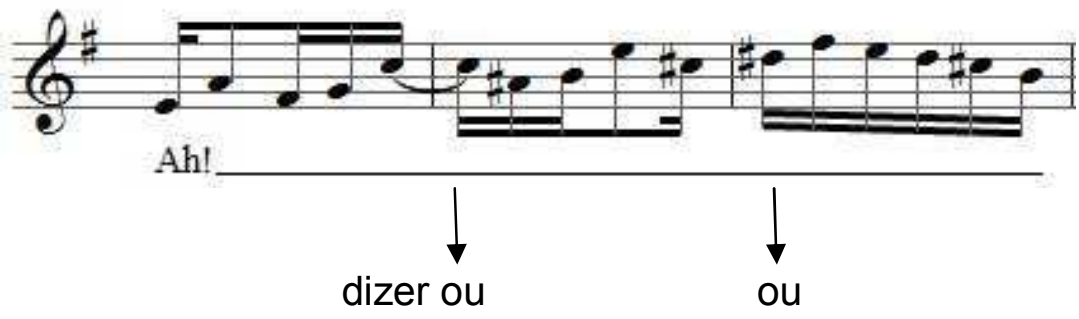

Os quartetos de Chansson irradiados hoje as 9 pela Cruzeiro, foram ótimos.

Terça-feira, 8 novembro 1938

$\left(87^{\mathrm{a}}\right.$ aula)

A lição de hoje foi excelente. Tive alta no Ritornerai pré foco, ai je-fail...??? Passou-me para estudar $\mathrm{O}$ del mio dolce ardor. 
Sexta-feira, 11 novembro 1938

(88 aula)

Hoje estou numa grande onda de "Spleen" numa dessas melancolias como há muito tempo não tinha. Apesar de tudo a lição foi boa, embora eu com as minhas exigencias não a achasse. Pela primeira vez cantei "O del mio dolce ardor" de Gluck, "Mon couer tu frémis", de Schumman. Dona Vera gostou da primeira. Achou ambas muito bem encaminhadas. No Gluck, tudo que ela corrigiu eu já havia notado e isso deu-me grande alegria por ver que reconheço meus erros Eu não gostava mas não sabia a forma de corrigir-me.

O del mio dolce ardor

\section{$(1.714+1787) \quad$ (C. Gluck)}

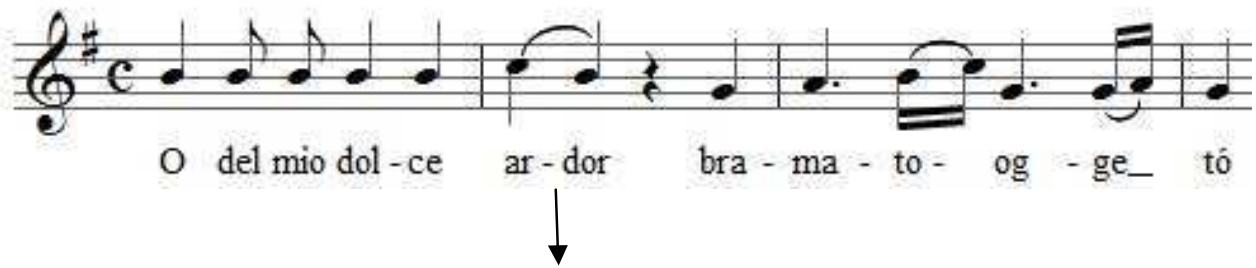

fazer toda a frase bem doce e muito piano.

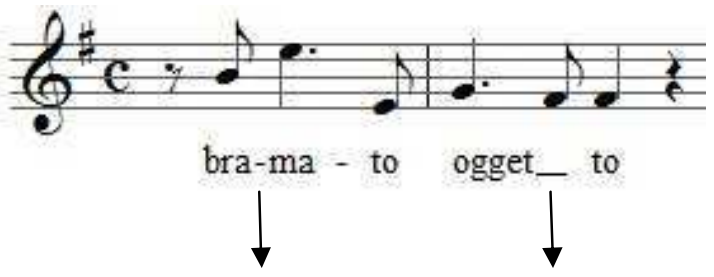

altura apoio cresc. cresc.
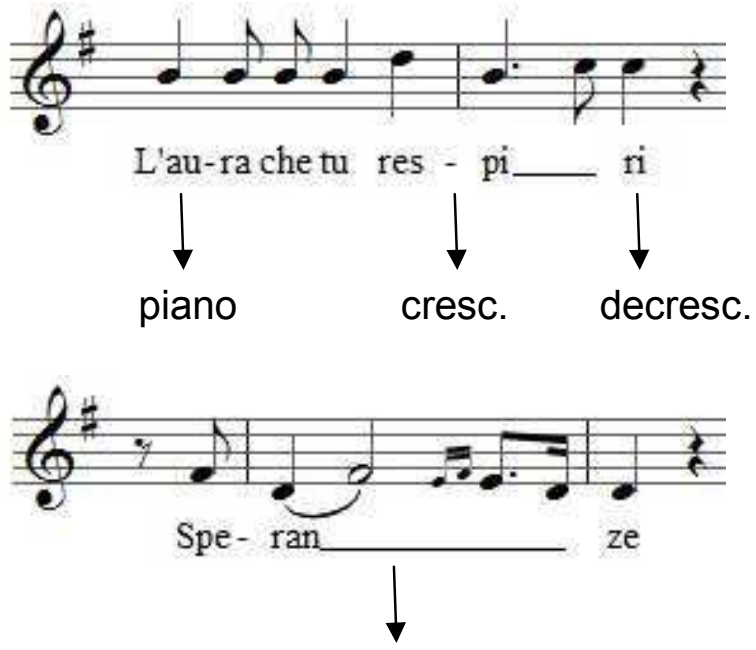

não fazer muito anasalado 


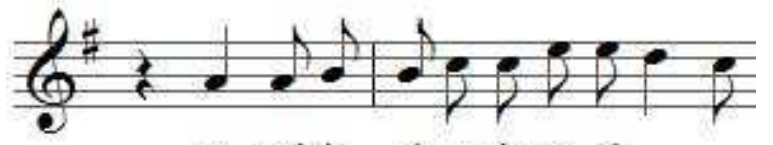

E nel de - si-o checo-si_
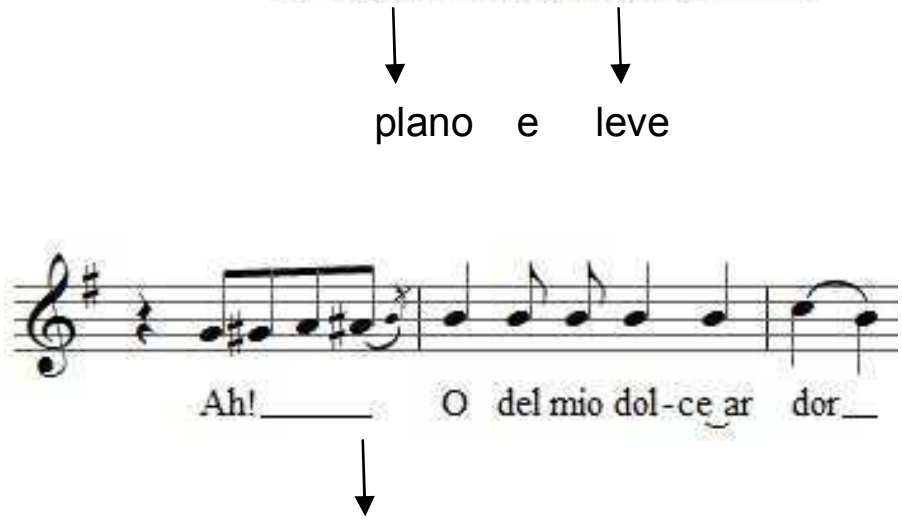

esta 2a. vez começar piano e crescendo

\section{Quarta-feira, 16 novembro 1938}

(89a aula)

Dei vocalizes e fui muito bem

\section{Sexta-feira, 22 novembro 1938}

$\left(90^{\mathrm{a}}\right.$ aula)

Dei uma aula muito boa que agradou bastante a Dona Vera. Nesse exercício foram os seguintes defeitos que Dona Vera corrigiu:

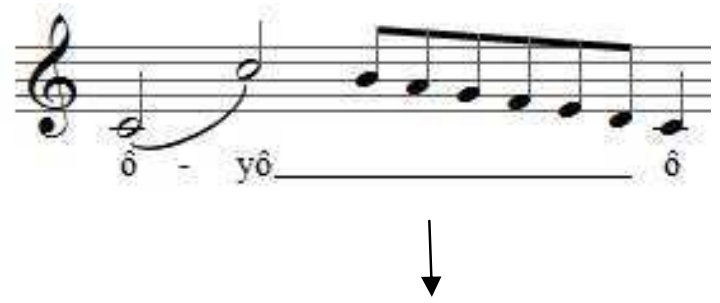

estou dando muito sopro nas notas agudas e abrindo muito a boca em certo as vogais. Modo de estudar: fazer o $2^{*}$ do de boca fechada abrir a boca iniciar alto, piano e ir aumentando o som com elasticidade. 
O del mio dolce ardor

$(1.714+1787) \quad$ (Gluck)
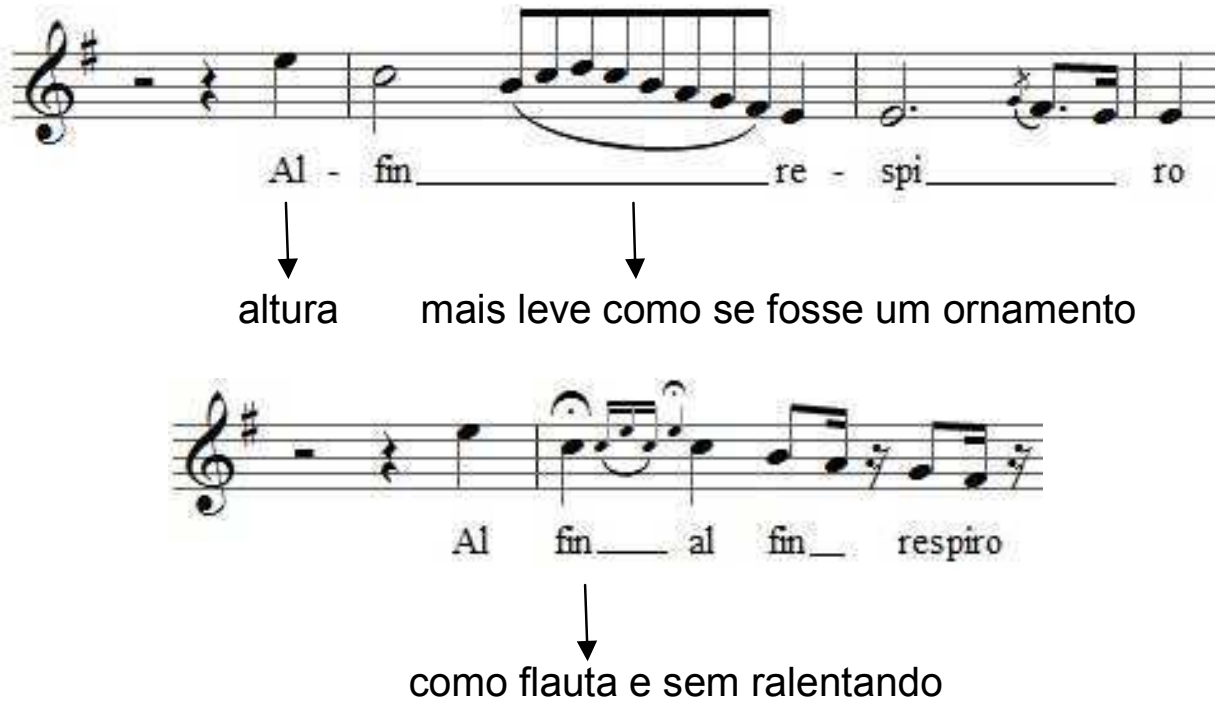

Dei hoje pela primeira vez o "Se tu m'ami" de Pergolesi e ainda não sei anotar claramente as explicações de Dona Vera. "Ah! Viens calmer ma fièvre" dei também como novidade.

\section{Sexta-feira, 25 novembro 1938}

(91 aula)

Cantei a seguinte vocalize

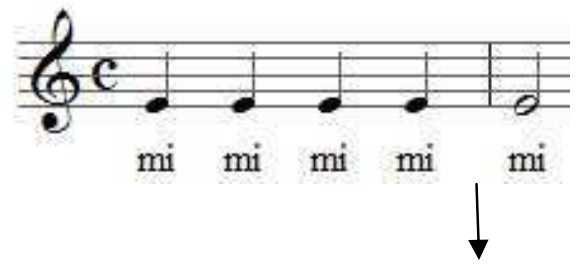

respirar, aumentar com apoio e alargar o tórax. Pouco sopro.

\section{$(1710+1736 \quad$ ( JB Pergolesi)}

Esta música deve ser cantada com graça, com ironia, ora com um desprezo, ora com um dó irônico e displicente.

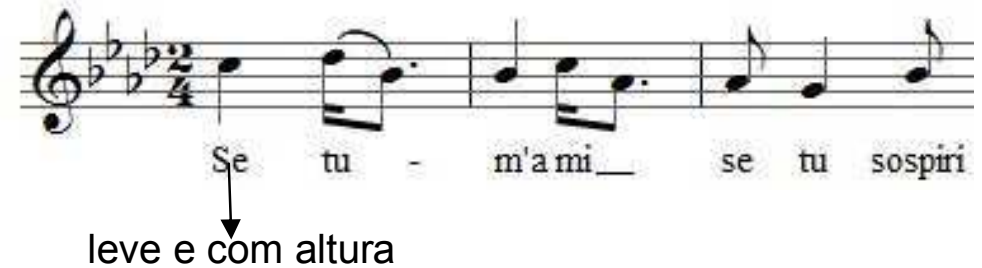



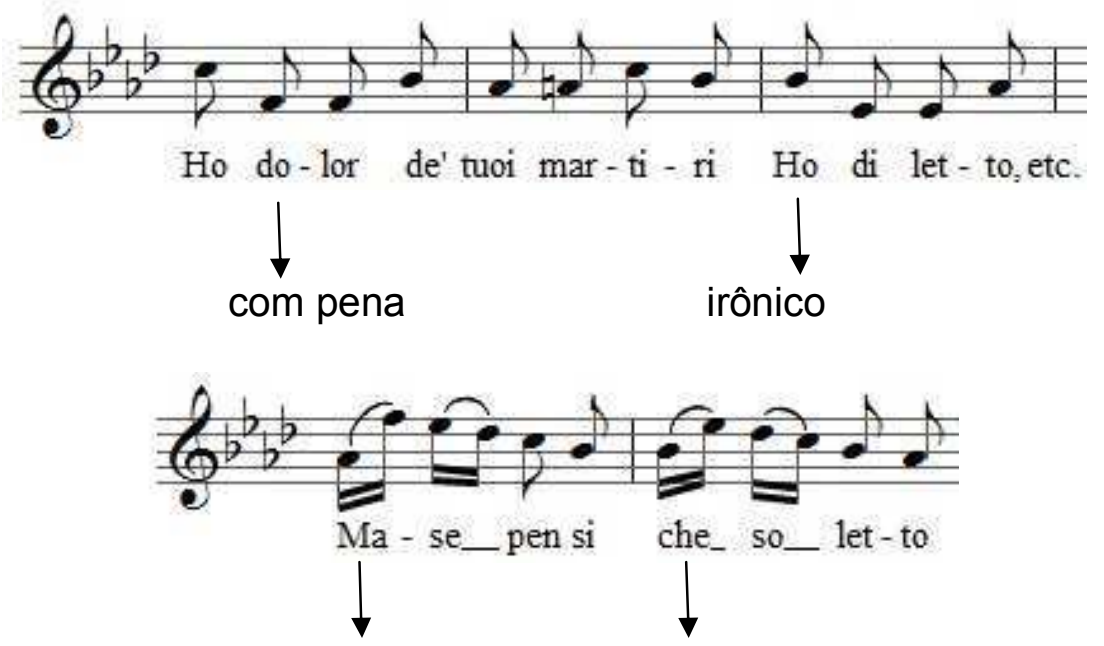

mais forte

mais piano. Devo prestar mais atenção para fazer claras as letras dobradas

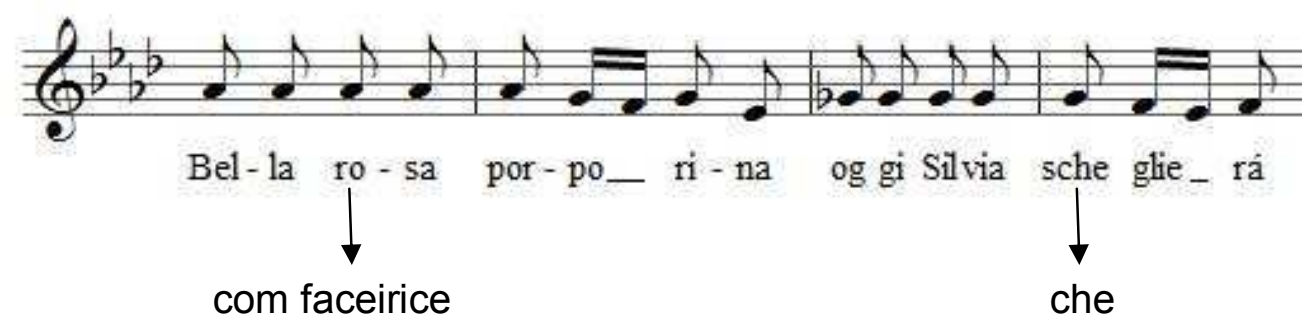

Como quem diz: assim como eu gosto de uma flor posso gostar de muitas, por isso, "pastorello", não se envaideça com o meu amor, porque eu posso querer a muitos pastores ao mesmo tempo.

O del mio dolce ardor

$(1714+1787)$

Gluck

Essa musica deve ser cantada como instrumentos, ora fazendo sentir violoncelo, ora flauta doce.

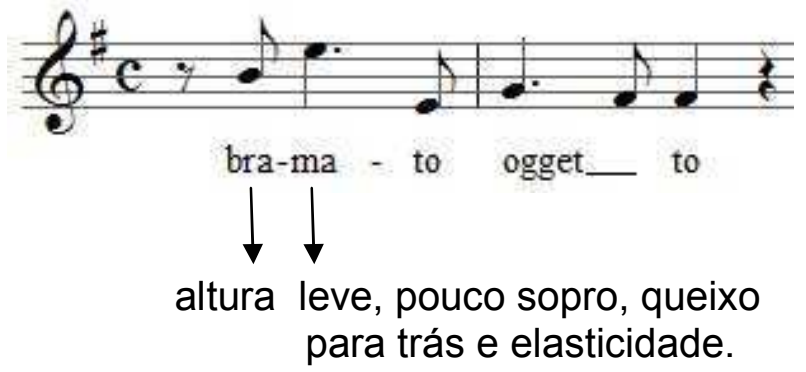




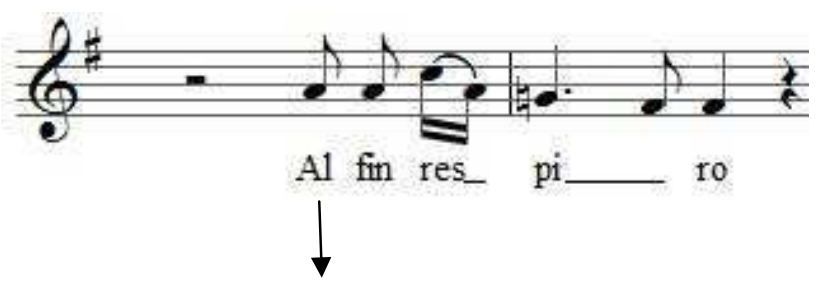

prestar atenção nas duas colcheias.

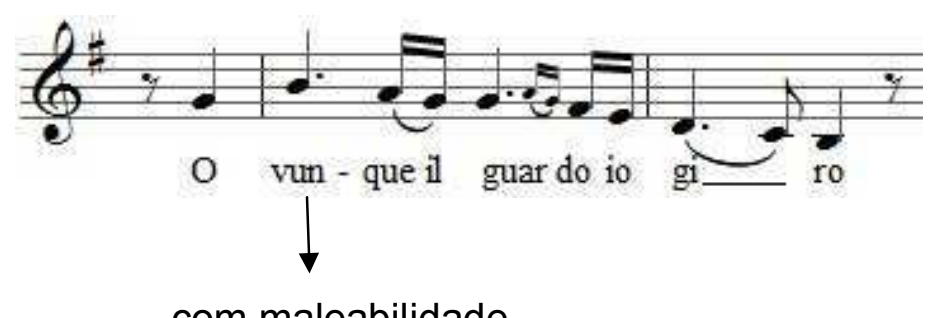

com maleabilidade

Terça-feira, 29 novembro 1938

(não houve aula)

Sexta-feira, 2 dezembro 1938

$\left(92^{\mathrm{a}}\right.$ aula)

Fui esplendidamente nas vocalizes e muito bem nas músicas. Dona Vera pediu-me para estudar o Romance de Debussy.

Terça-feira, 6 dezembro 1938

(93 aula)

A lição de hoje foi bem longa e relativamente boa. Iniciei com os exercícios "Mi-mi-mimi" e com o de três arpejos. O primeiro Dona Vera quer que eu comece bem de cabeça, bem pontudo e ir aumentando com alargamento e bocejo. No outro, é preciso abrir mais a boca no inicio e sentir muito apoio nas notas agudas.

Sexta-feira, 9 dezembro 1938

(94 aula)

Dona Vera deu alta ao Pergolesi e ao Gluck.

Qh! Viens calmer ma Fièvre

$(1810+1856) \quad$ (Schumman) 

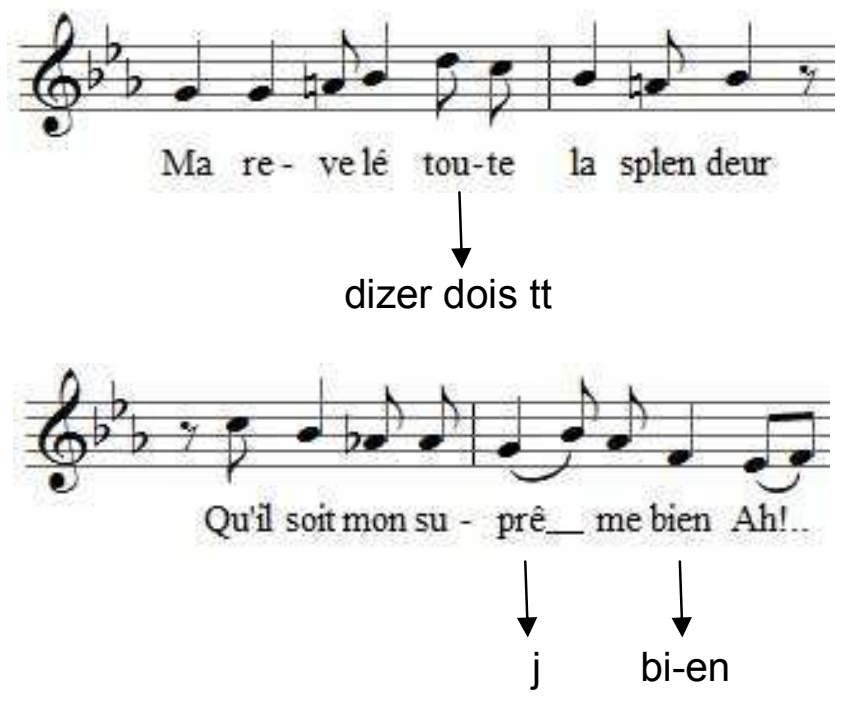

Terça-feira, 13 dezembro 1938

(95 lição)

L’aube rayonne

$(1810+1856)$ (Schumman)

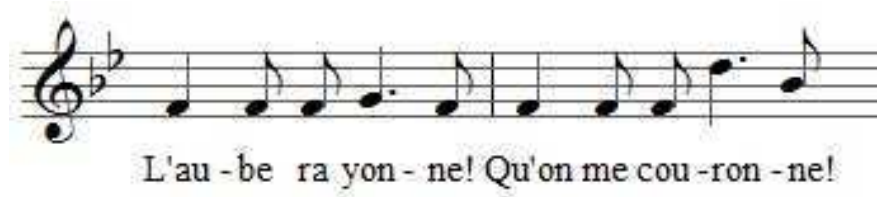

Tu veux lire dans mes yeux

$(1810+1856) \quad$ (Schumman)

Preciso apenas tomar cuidado para não soprar nos inícios das frases.

Romance

$(1862+$

(C. Debussy)

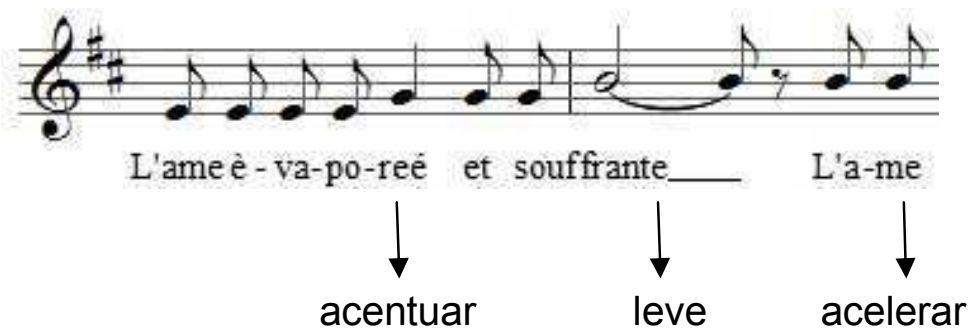




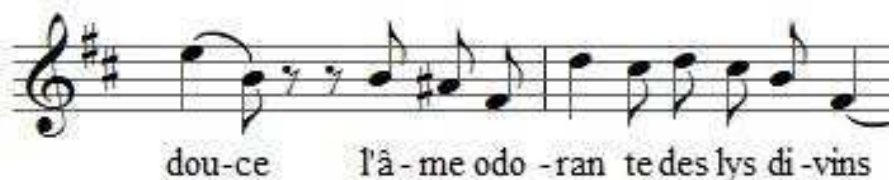

dou-ce lâ-me odo-ran te des lys di-vins
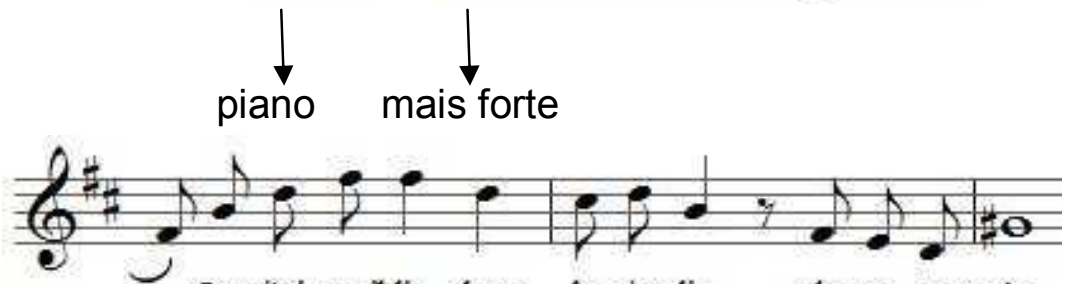

Quejai cueil lis dans le jardin de ta pensée

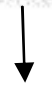

a consoante leve e com o apoio.

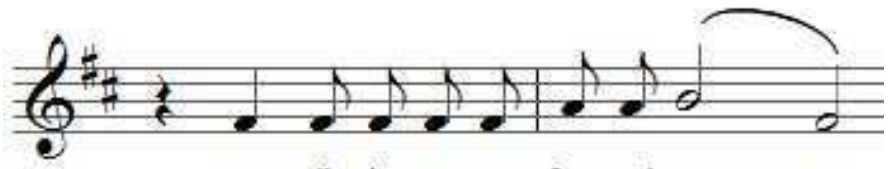

N'est il plus un par-fum qui res - te

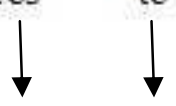

acentuar leve

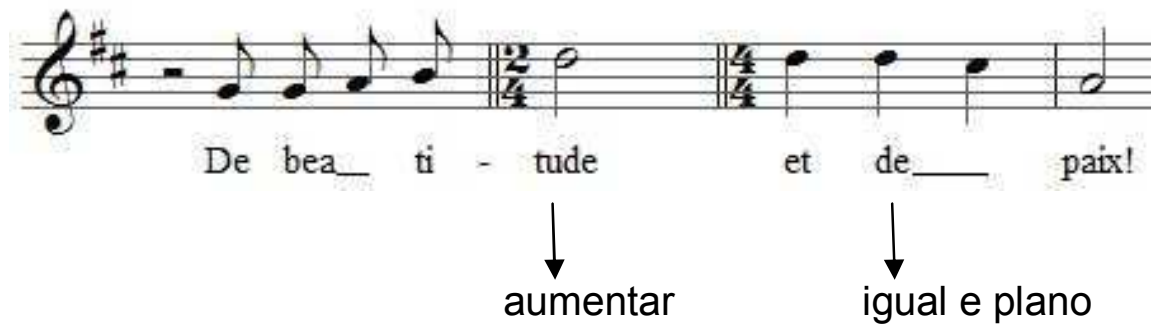

\section{Sexta-feira, 16 dezembro 1938}

(96 aula)

As vocalizes foram ótimas. Dei o L'aube rayonne que foi muito bem.

L'aube rayone

$(1810+1856) \quad$ (Schumman)

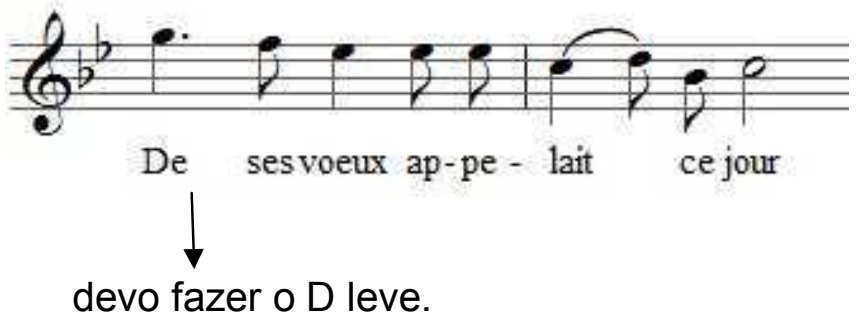


O mais tudo não teve o que corrigir. Dona Vera gostou bastante.

Tu veux lire dans mês yeux

$(1810+1856)$

(Schumman)

Dona Vera acha que, nesta música, como eu tenho de empregar muitas notas de cabeça é preciso que eu faça, de quando em quando uns $<>$ afim de não ficarem afetadas devo ter mais maleabilidade.

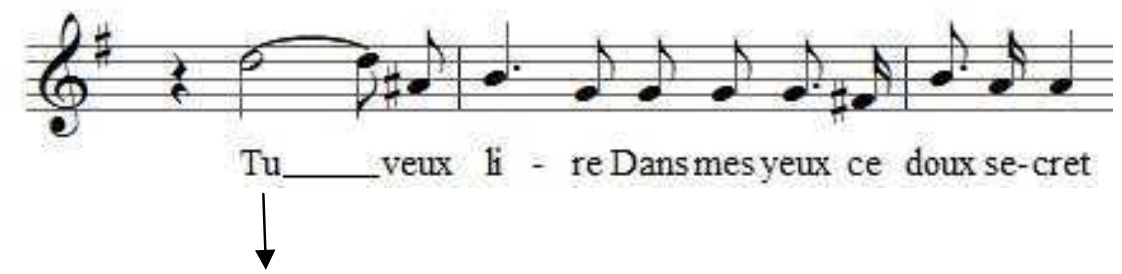

iniciar de cabeça aumentar um pouco, queixo mole e flexibilidade natural.

\section{Terça-feira, 20 dezembro 1938}

(97 aula)

AS vocalizes foram ótimas, melhoraram consideravelmente.

Clos la paupière

\section{(1810+1856) (Schumman)}

Está música deve ser cantada mais leve, com mais doçura na voz como quem está embalando uma criança querida; cheia de jubilo, de encantamento, de êxtase e de amor maternal.

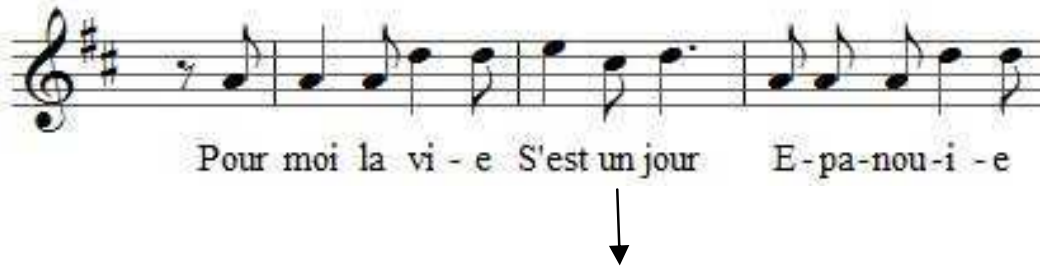

esta frase numa só respiração.

\section{Quarta-feira, 21 dezembro 1938}

(98 aula)

O Heurs Amers!

$(1810+1856) \quad$ (Schumman) 


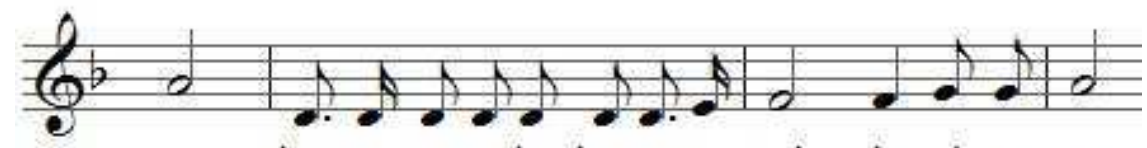

o pleurs a-mers ô dou-leur é-ter - nel - le! Tris-te sort!

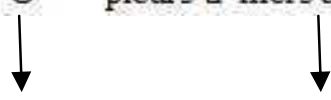

começar com

cortar

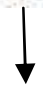

um soluço, voz

sem

quente e triste

respirar

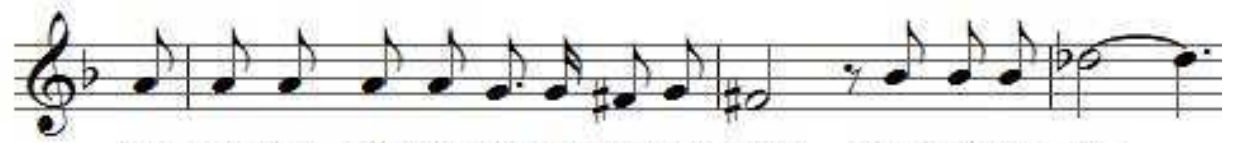

Ma voix l'ap - pelle, Et dans la nuit se perd! Tout estmu- et!...
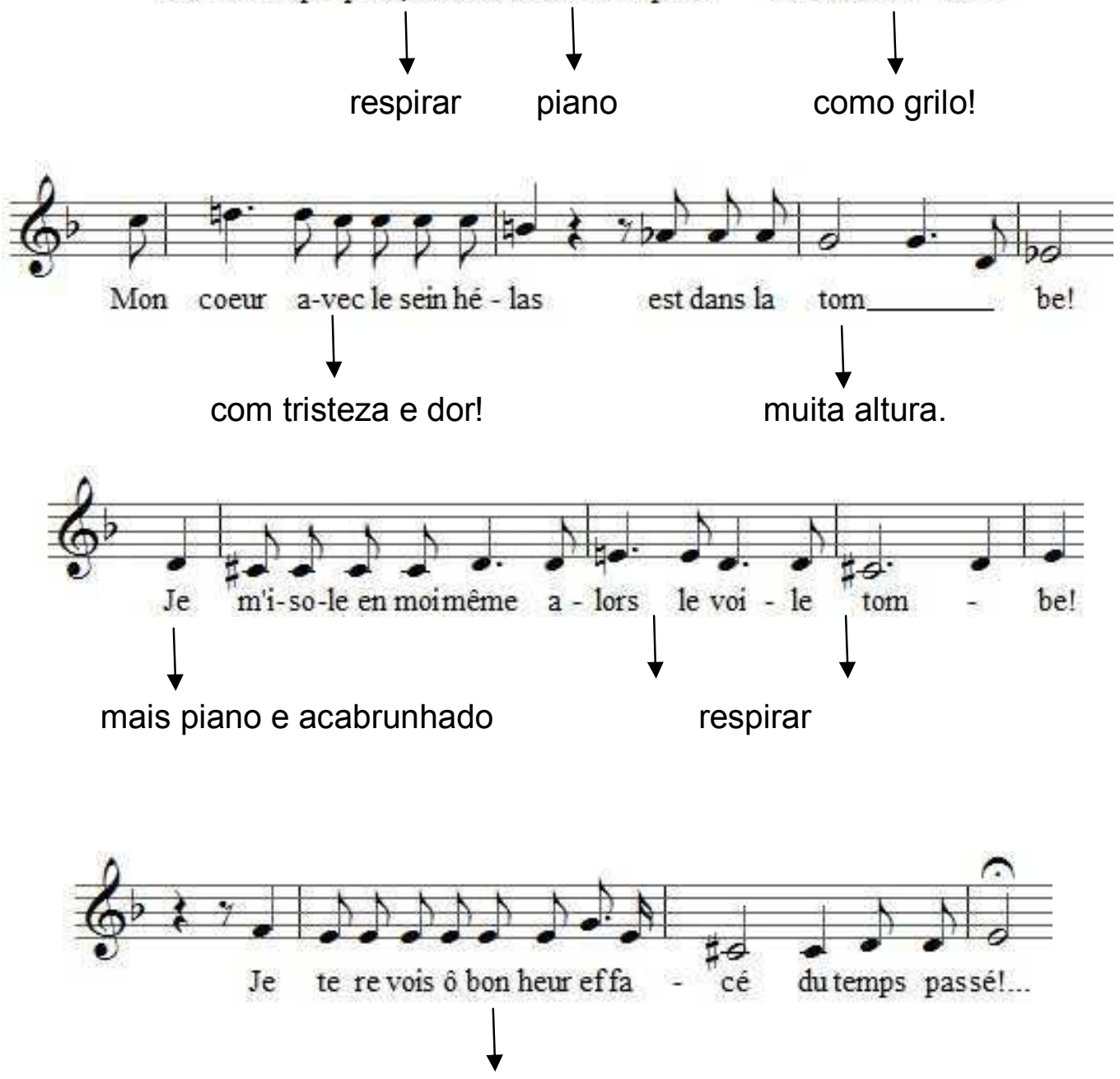

com dor e saudade! 
1939 


\section{Sexta-feira, 3 março 1939}

(99a aula)

Primeira aula de 1939!

Dona Vera notou em mim grandes progressos. As vocalizes foram bem. Dona Vera achou enorme diferença em tudo; em altura, em timbre, nas articulações de boca, etc. Todas as vogais estão na mesma altura, a lingua bem pousada e o excesso de sopro corrigido.

Dei o "Ch'io mai vi possa" de Haendel e "La poste" de Schubert. Dona Vera achou ambas com pequeníssimos defeitos.

Ch'io mai'vi possa

$(1685+1739) \quad$ (Haendel)

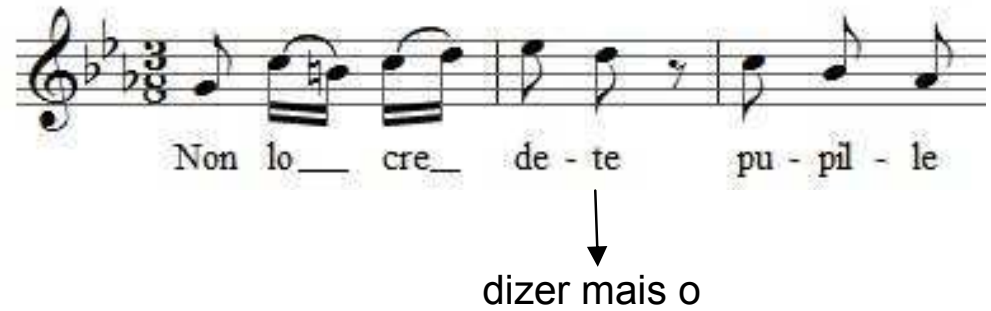

La poste

$(1797+1828) \quad$ (Schubert)

Dona Vera corrigiu-me em certas interpretações. Devo fazer $1^{*}$ muito mais ansioso, e, quando chegar o "Allons quel vain" muito mais doloroso e desiludido.
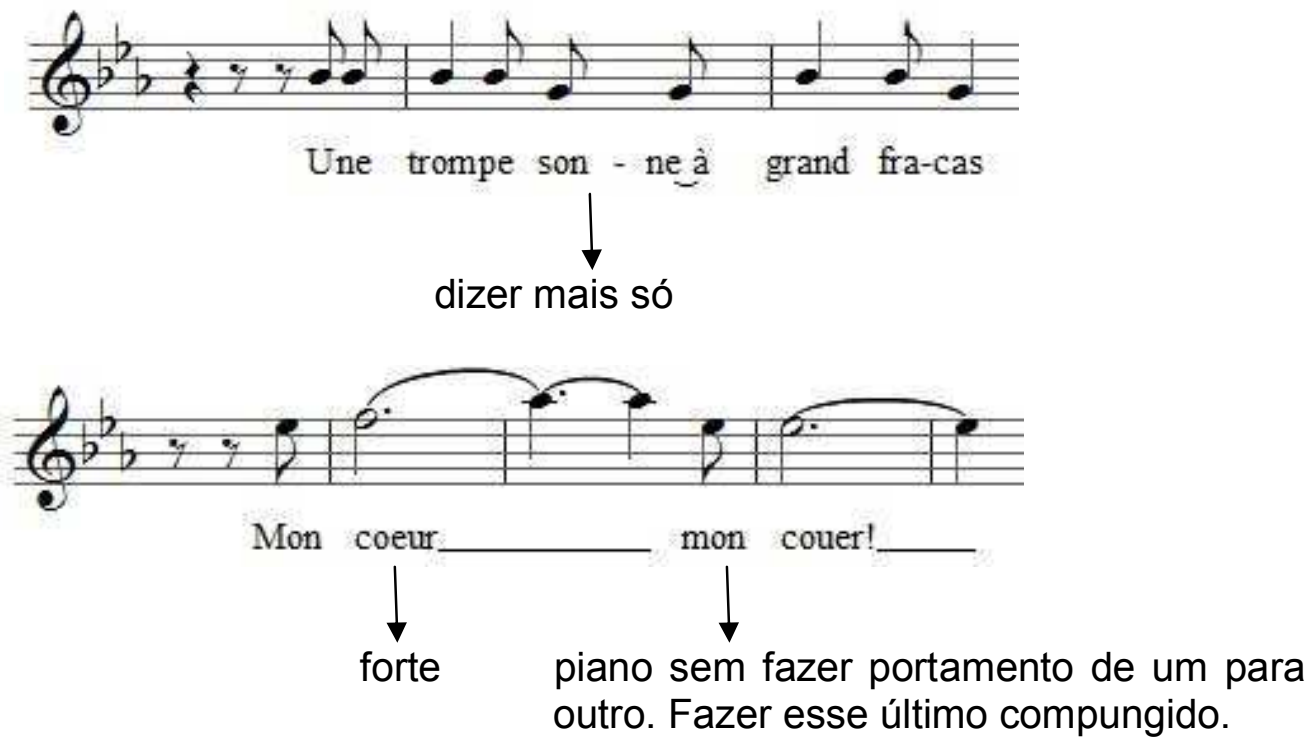
Terça-feira, 7 março 1939

(não houve aula)

\section{Sexta-feira, 10 março 1939}

$\left(100^{\mathrm{a}}\right.$ aula $)$

Em "Ch'io m'ai vi possa" nada houve a corrigir a não ser mais altura nos pianíssimos.

Recitativo e Ária de Rinaldo

$(1.685+1759) \quad$ (Haendel)

Dona Vera achou que eu devo cantar mais leves a $s$ terminações das palavras e que devo

Fazer mais diferenças em cada frase visto serem elas muito iguais. Ela quer da seguinte forma: a 1+ vez mais forte, mais timbrado e instrumental; a $2^{a}$, mais piano e acabar cheio e forte. Fazer esta frase deste jeito:

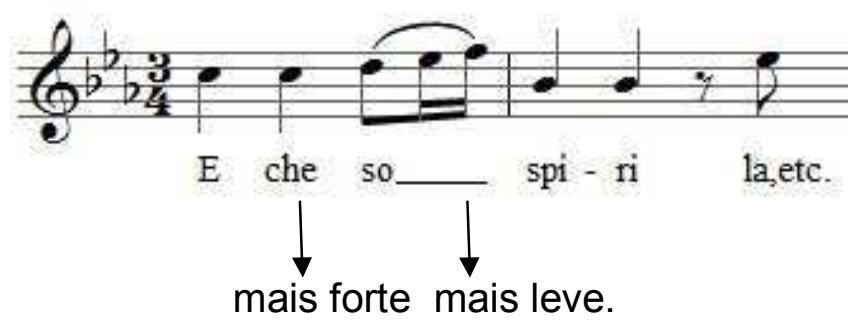

Terça-feira, 14 março 1939

$\left(101^{\mathrm{a}}\right.$ aula)

Dei uma lição esplendida! As músicas e as vocalizes foram muito bem. O "ch'io mai vi possa" não teve absolutamente nada a corrigir, como interpretação, estilo e emissão. No "Lascia ch'io pianga" Dona Vera achou grandes progressos mas, notou que eu canto o "e che sospiro" muito de cabeça. Não devo fazer muito piano, mesmo porque, sendo demasiado piano não demonstra a dor necessária que a musica exige. Em "La poste" tive alguns esclarecimentos na interpretação. Devo fazer ainda mais ansioso e variar o mais possível os "mon coeur" Um deve ser angustioso, o outro cheio de ansiedade e muito expansivo, agitado, como a espera de carta, outro desiludido. 
La poste

$(1.797+1828)$

(Schubert)
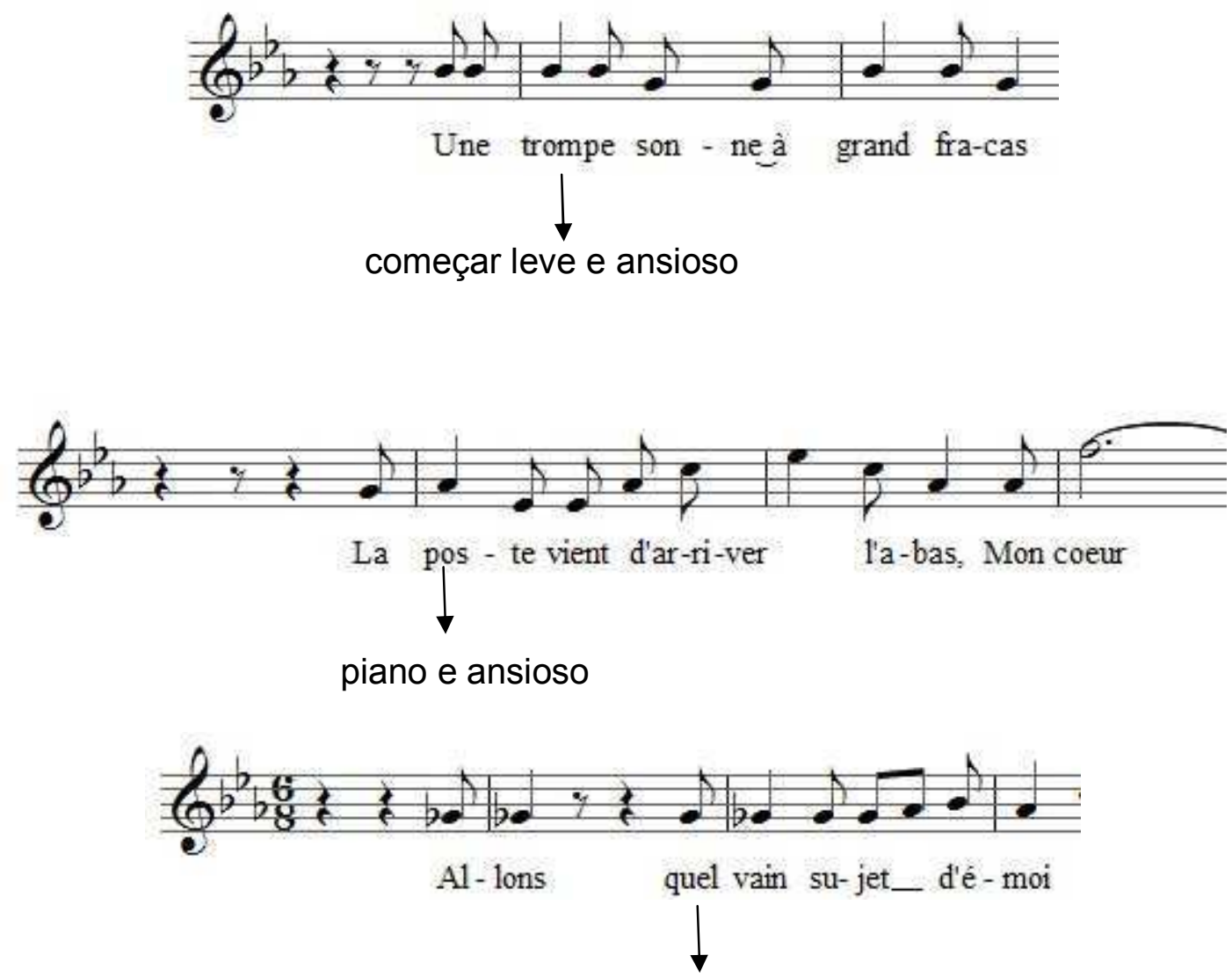

triste, amargurado.

Para a próxima aula vou levar três músicas novas. Escolhi "Chanson triste de Duparc ", "Le charme de Chausson" e "Plaisir d'amour de Martini".

\section{Sexta-feira, 17 março 1939}

(102 a aula)

Dona Vera hoje, só posso descrever dessa forma: o quanto tinha de bondade e simpatia, tinha de exigências. Estava que nada perdoava; numa respiração mal feita numa nota levemente soprada, numa semicolcheia meio fechada enfim... não houve indulgência. As vocalizes não foram de todo mal. "plaisir damour" foi tão corrigido que, pelo que vejo, ela não gostou.

Plaisir d`amour

$(1.791+1816) \quad$ (Martini)

Deve ser cantado da seguinte forma: sentir mais de 6 em 6 . A $1^{*}$ vez deve ser apenas amargurado, nostálgico fazendo uma diferença no "chagrin d'amour" 

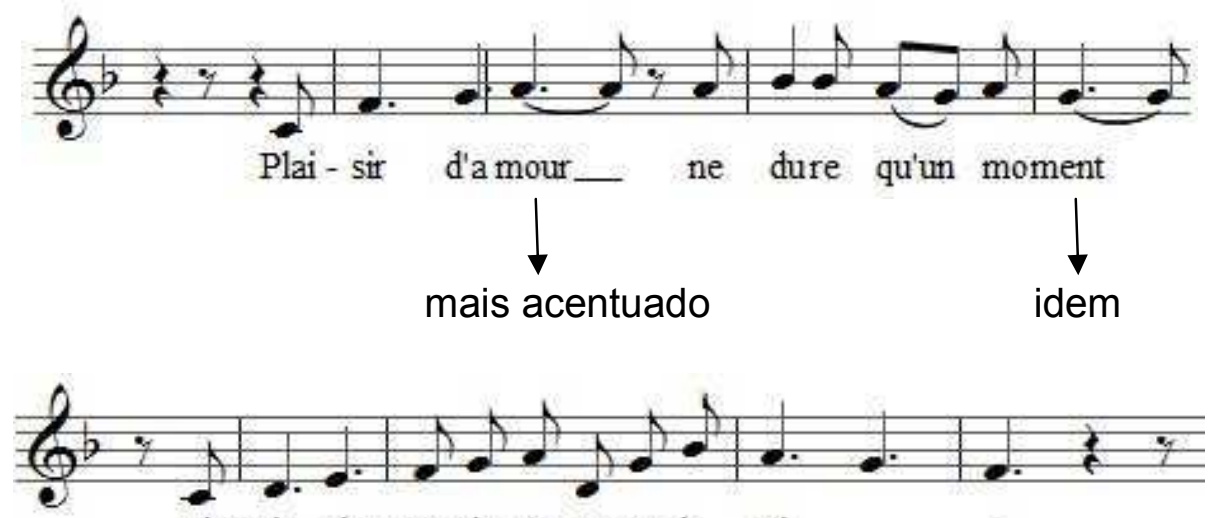

Chagrin d'amour du-re toute la vi_e e

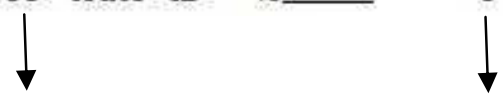

mais doloroso

maleável

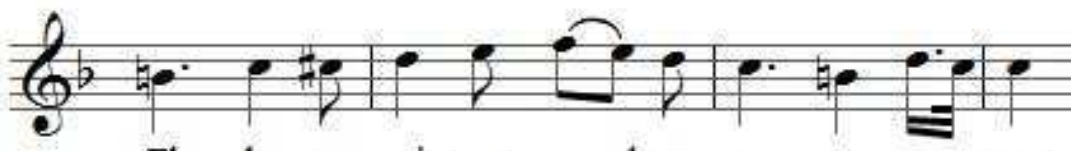

El - le me quit-te et prend un au - tre a mant

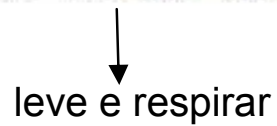

O 28 "Plaisir d`amour, etc" mais piano e mais doloroso.

Esse trecho seguinte deve ser cantado com ternura, bem doce e acariciante, como quem está embalado por um sonho lindo.
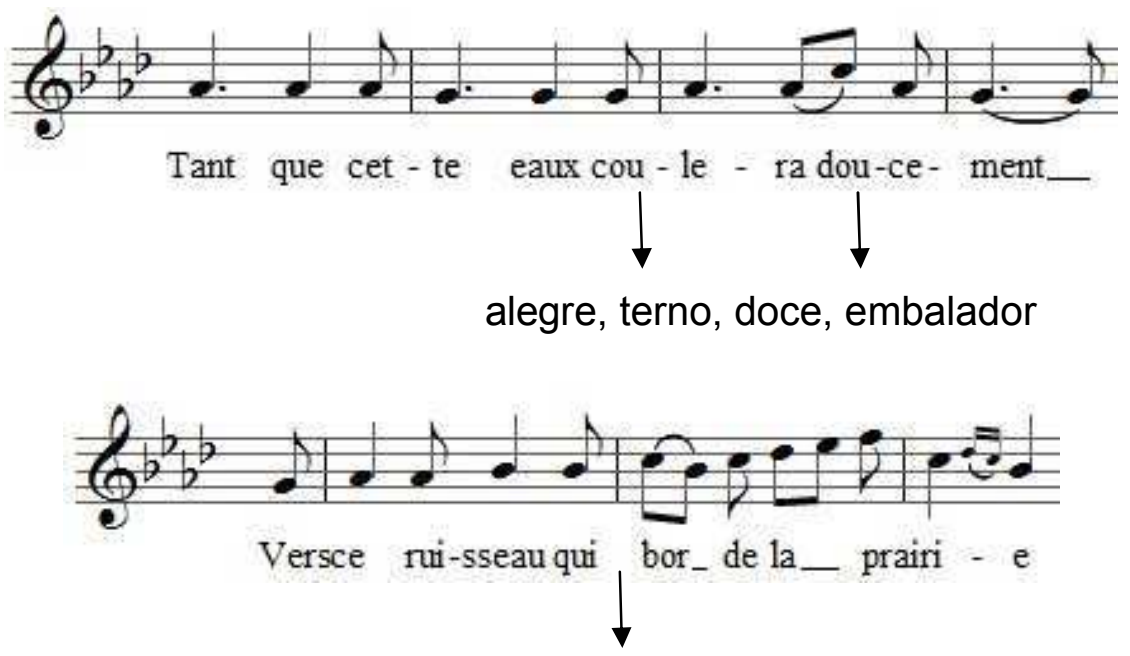

numa só respiração e bem leve. Pouco sopro. 


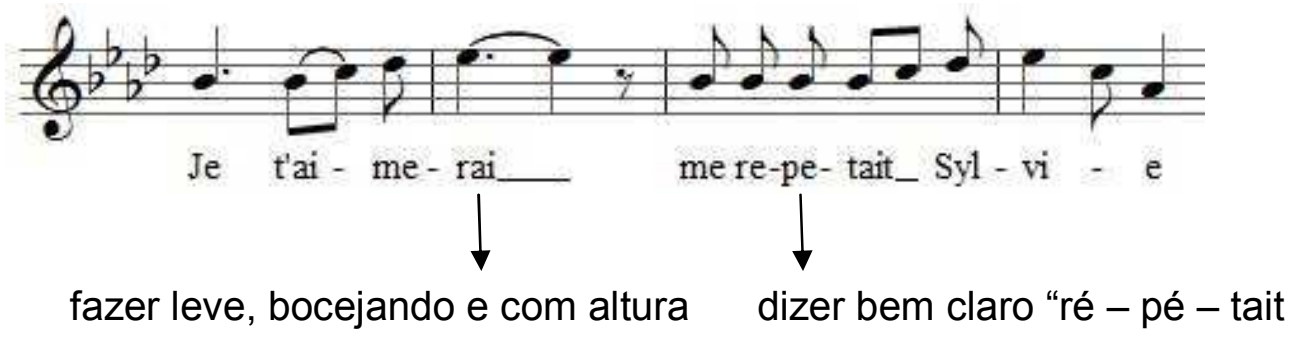

"L`eau coule etc" compungido como quem encontre a realidade.

Quanta coisa a corrigir! Estou até desanimada!

Chanson Triste

(1848+ $\quad$ (Duparc)

Deve ser não propriamente triste, mas sim desanimada como uma pessoa doente que não espera a cura. Dna Vera achou que eu fiz cada frase como se fossem várias frases. Devo fazer muito mais plano.

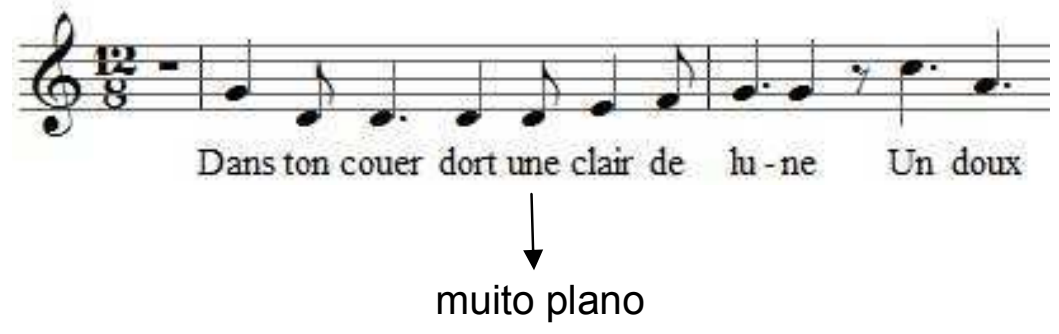

No trecho que segue achei linda a explicação de Dona Vera. Pois o modo que ela me explicou fez ficar a frase mais quente, mais luminosa.

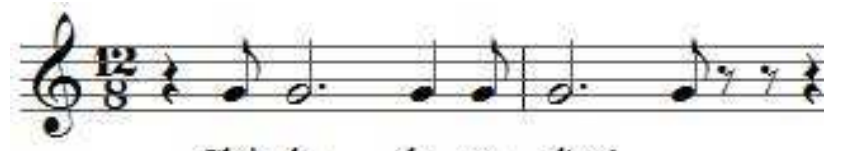

Clair de lu-ne d'eté.

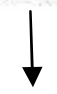

aumentar com bocejo e alargamento, sem chegar ao forte.

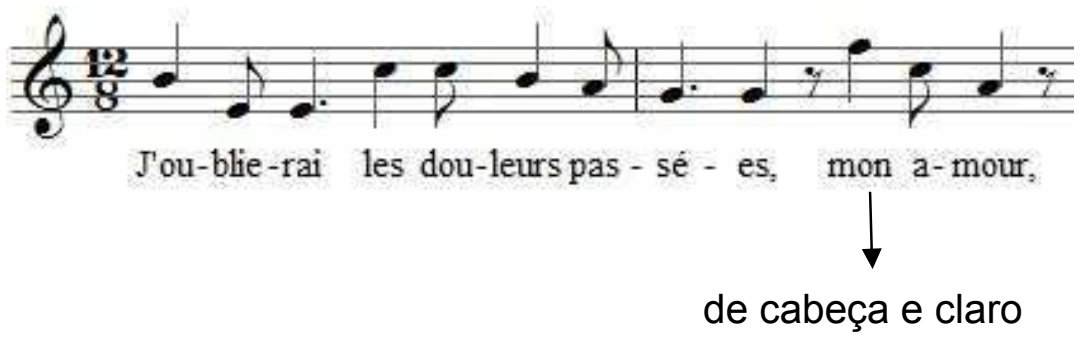




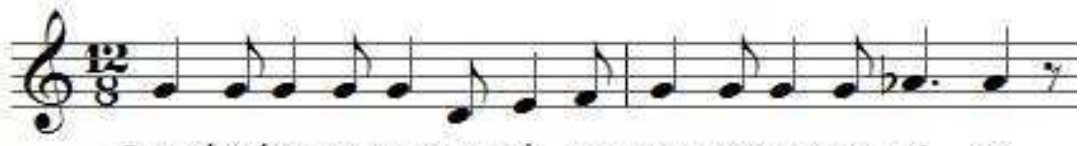

Quand tu ber-ce-ras mon tris - te coeurs et mes pen - sé - es

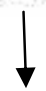

só respiração, poupar o sopro e leve

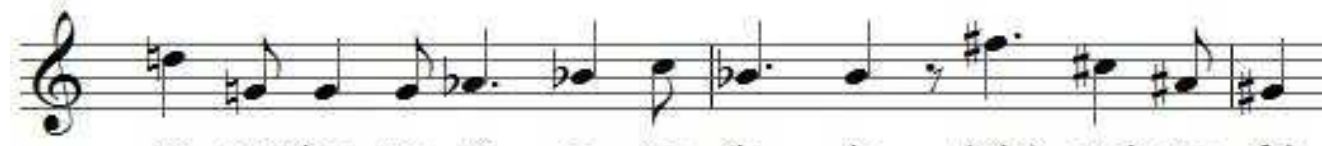

Tu prendras ma tê - te ma - la - de (Oh!) quel-que - foi

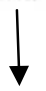

leve, maleável para não apitar

apoio e altura

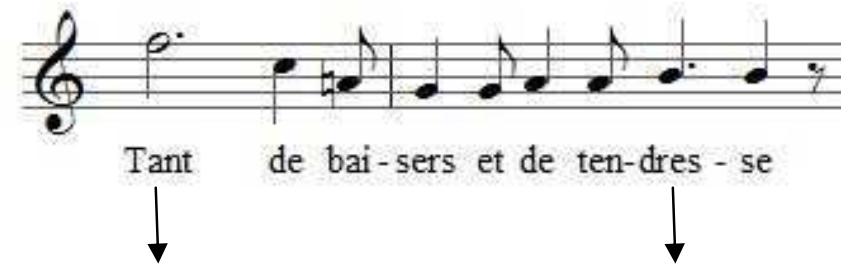

dizer na altura de au mais "So". Dar o apoio e atacar a nota direta de cima para baixo. Por muita doçura no "tendresse".

\section{Terça-feira, 21 março 1939}

$\left(103^{\mathrm{a}}\right.$ aula)

Fui bem nos exercícios. Dona Vera recomendou-me o exercício "Do-re-mi-fa-sol-fa-mire-do" mais para estudar da seguinte forma de boca fechada e, caso nos agudos eu sinta alguma dificuldade, cantar três a quatro vezes bem rápido emitindo em seguida bem lentamente.

"Chanson triste" o andamento deve ser mais rápido. A !* frase deve ser plana sem deixar a ondulação.

\section{Sexta-feira, 24 março 1939}

(104 aula)

Fui esplendidamente às vocalizes.

Terça-feira, 29 março 1939

(não houve aula) 
Sexta-feira, 31 março 1939

(não houve aula)

Segunda-feira, 3 abril 1939 (105* aula)

Cantei somente vocalizes e fui muito bem.

Terça-feira, 4 abril 1939

$\left(106^{\mathrm{a}}\right.$ aula $)$

Dona Vera gostou muitíssimo da forma que cantei o "Plaisir d’amour" e a "Chanson triste". Ela só achou que no "tant que cette eau" devo fazer a voz mais clara e feminina.

Sábado, 8 abril 1939

$\left(107^{\mathrm{a}}\right.$ aula $)$

Nada houve a corrigir.

Terça-feira, 11 abril de 1939

Cantei as vocalizes com bastante facilidade, altura e timbre. Déia escala de Lili Schumman. Ele, no seu livro de estudo de canto diz:

"Ces't l'exercice fui est le plus nécessaire a toutes les voix. Comme eleve au doit le travailler deux fois par jour. Comme chanteur de profession, au moins une fois.

Sexta-feira, 14 abril 1938

(109a aula)

Dei hoje ainda mais uma vez Chanson triste e Plaisir d`amour. Cantei pela primeira vez "Bonne Nuit" de Shubert que Dona Vera achou bem. Achou somente que deve ser mais alegre, resoluto e confiante.

Bonne Nuit

$(1797+1828)$

(Shubert)

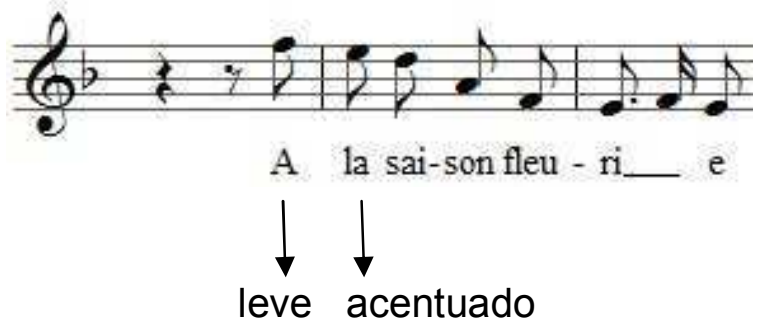



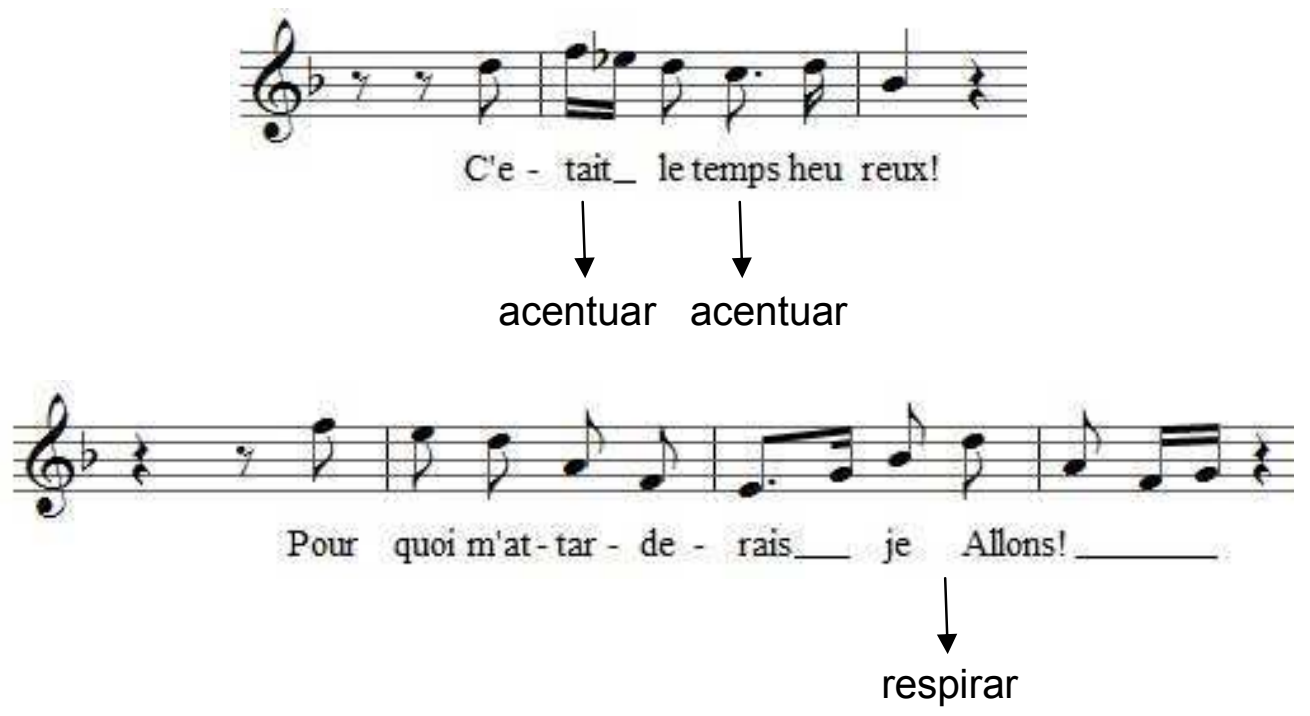

Terça-feira, 18 abril 1939

(110 aula)

Dei hoje uma ótima aula. Cantei Ch`io m’ai vi possa, Lê poste para repassá-las para cantar na audição de amanhã. Bonne Nuit Dona Vera aconselhou-me a estudar 1 tom abaixo, 1 tom acima para voltar depois a tonalidade escrita.

\section{Quarta-feira, 19 abril 1939}

Dona Vera deu hoje a primeira audição e sua casa. Fiz minha estréia com bastante porte.

\section{Quarta-feira, 26 abril 1939}

\section{$\left(111^{\mathrm{a}}\right.$ aula $)$}

Tive mais uma aula de vocalizes e fui mais ou menos bem. O exercício "i-i-i-i" Dona Vera corrigiu da seguinte forma: os graves estão apertados, talvez por eu fechar demais a boca. Nas notas bem agudas, quando eu passo para os graves, faço uma queda da laringe provocando um chiado. Para evitar que isso suceda, devo dar pouca intensidade de sopro na última nota, levantá-la bem e emiti-la bem alta dando a mesma altura a nota grave. 


\section{Sexta-feira, 28 abril 1939}

\section{$\left(112^{\mathrm{a}}\right.$ aula $)$}

Hoje desde cedo estou me sentindo muito nervosa e isso prejudicou-me muito na hora de cantar. Dei novamente "Bonne Nuit" que Dona Vera achou melhor. Ela acha que eu devo fazer mais diferença, quer dizer, devo variar mais na interpretação.

Bonne Nuit

(Shubert)

"La jeune fille tendre, etc" fazer mudança de voz, mais claro e forte.

“C'etait le temps heureux" tudo feliz.

"L'hiver afait ravage" pronunciar bem oravage.

"Eh bien partons courage em route etc." bem decidido.

"La femme est bien volage" com indulgência

"Sans bruit j’atteins la porte" começar o andamento bem mais lento

"Mignonne bonne nuit" tomar cuidado para não cair nas notas graves, para dar alguma altura também nos agudos.

Dona Vera pareceu não desgostar de maneira que estudei "se florindo è Fedele"

Se florindo è Fedele

$(1.649+1725) \quad$ (Scarlatti)

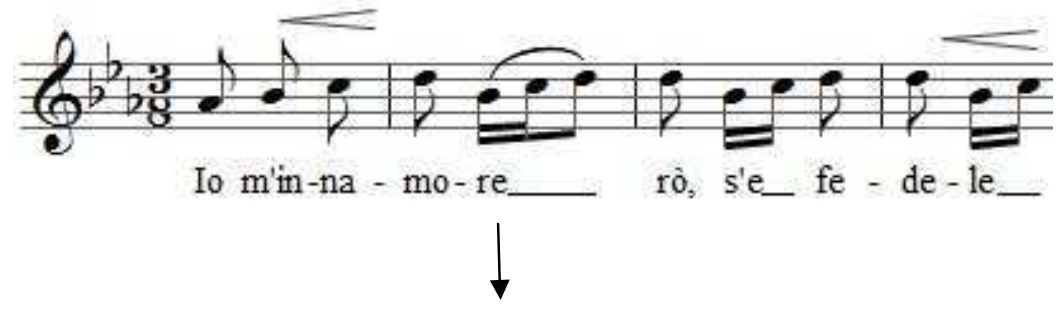

obedecer bem os crescendos e diminuendos

Prestar atenção em dizer bem claramente as consoantes dobradas como: m'innamorerò, etc. 
Terça-feira, 2 maio 1939

$\left(112^{\mathrm{a}}\right.$ aula $)$

Dei somente aula de vocalize. No execício "mô-ô-mô" Dona Vera quer que eu ponha o queixo bem para trás um dois ou três antes das notas agudas.

Sexta-feira, 5 maio 1939

$\left(113^{\mathrm{a}}\right.$ aula)

Dei hoje uma lição interessantíssima, primeiro por cantar bem e depois porque Dona Vera deu-me umas explicações tão claras, tão inteligentes, tão luminosas que me fizeram achar tudo mas fácil. Dona Vera achou muito bem o "Bonne Nuit"; vocalmente e como interpretação. Corrigiu apenas o seguinte: em todas as frases de Bonne Nuit devo sentir mais o plano e mais acentuados os acentos tônicos.

Bonne Nuit

$(1797+1828)$

(Shubert)
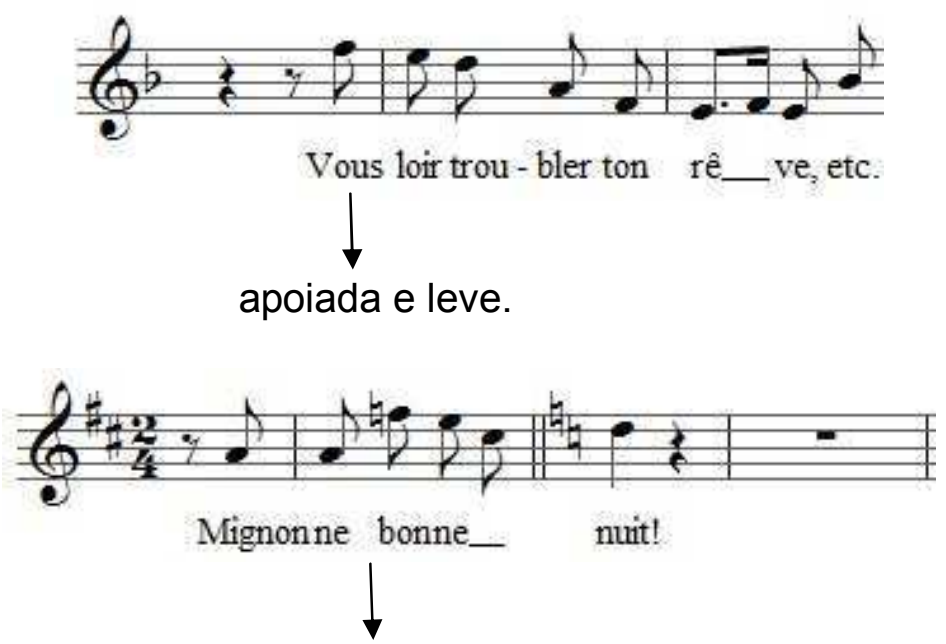

fazer mais plano e com altura. Dona Vera acha que euestou acentuando muito toda as notas, preciso fazer mais os acentos tônicos.

Le Charme

(1855+1899) (Chansson)

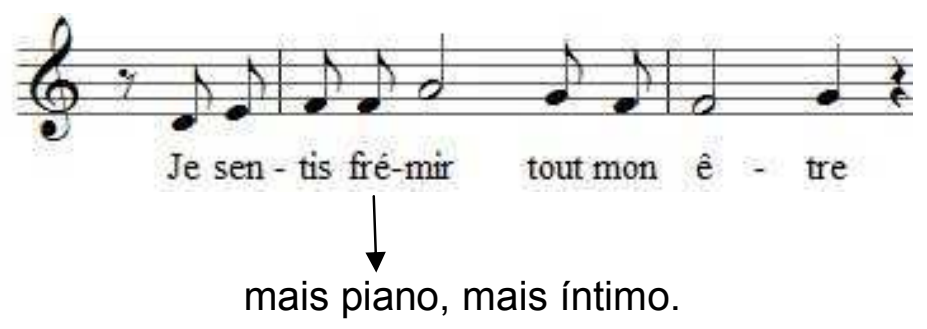



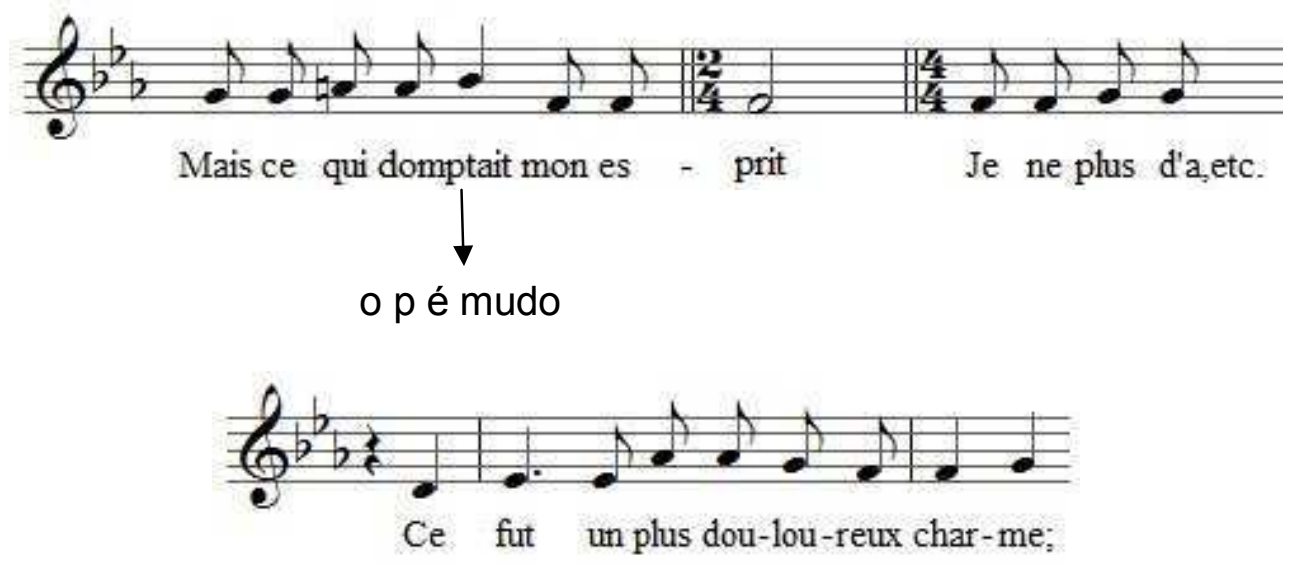

desejar bastante o ch para que o charme fique mais doloroso.

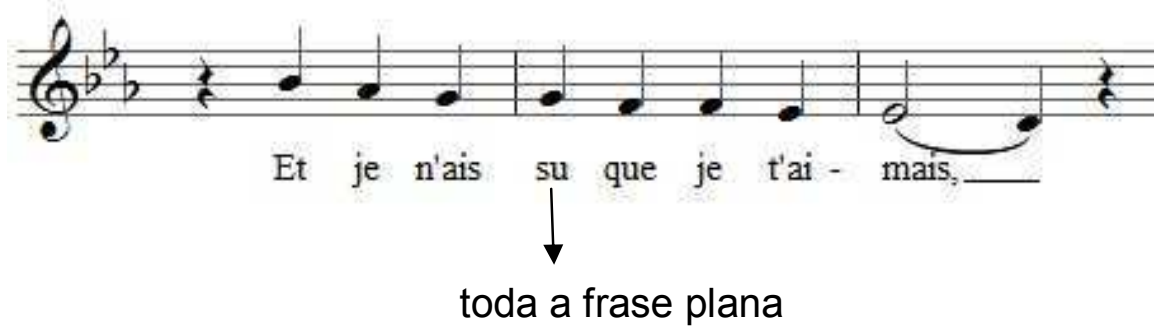

Devo fazer toda a música com mais variedades na interpretação, fazer mais colorido e mais mudanças de voz.

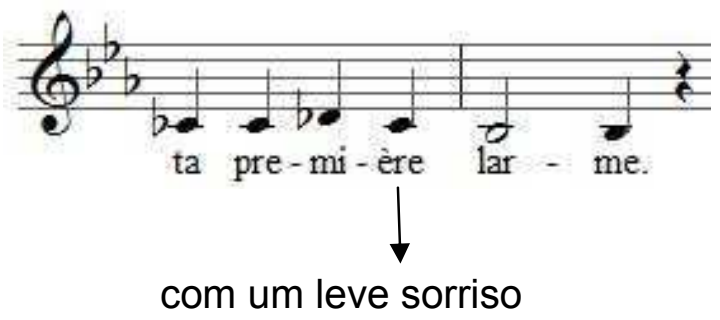

Se Florindo e fedele

$(1649+1725) \quad$ (Scarlatti)

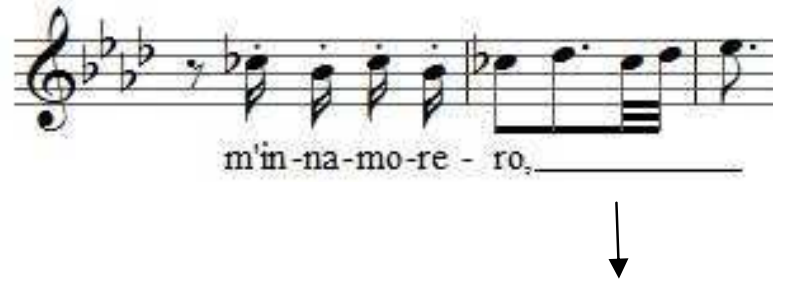

fazer mais leves as semicolcheias. 
Terça-feira, 16 maio 1939

(114 ${ }^{\mathrm{a}}$. aula)

Dona Vera notou grandes progressos nas minhas musicas. Gostou muito de "Se florindo e fedele" quer apenas que eu cuide mais da interpretação. Le charme ela achou quase ótimo.

\section{Quinta-feira, 17 maio 1939}

Fui bem na lição de hoje.

\section{Sexta-feira, 18 maio 1939}

$\left(116^{\mathrm{a}}\right.$ aula)

A minha maneira de respirar hoje estava horrível merecendo críticas enérgicas de Dona Vera. Dei hoje pela primeira vez "amour que veux tu de moi" de Lulli, Revê de primtemps de Schubert. Dona Vera achou que no Automne eu fiz certas notas muito nasais.

Automne

(Fauré)

"Automne au ciel brumeux" dizer autómne.

"Torrent" dizer mais au sem anazalar demais.

"Melancolie. Co

"Sur l'aile des regrets mes esprits". Sem ondulação e plano.

"Comme s'il se pouvait que notre age" fazer uma só respiração.

"Refeurir em bouquet les roses, etc." fazer uma só respiração.

Rencontre

(Fauré)

“Je sens moins aujourd`hui mon, etc. fazer numa só respiração.

“O passante aux doux jeux". Bem doce e piano.

"Et vas tu rayonner sur mon âme" começar piano, aumentar numa só respiração.

"D’exilé!" na altura de i.

"Ta tristesse sauvage, etc" mais forte e voz quente. 
"Sans te connaitre bien" iniciar só aqui o pp.

Terça-feira, 23 maio 1939

(117 a aula)

Hoje, depois de minha lição houve a segunda audição e, porque não dizer? Cantei explendidamenrte. A respiração estava calma. Dicção ótima, voz e interpretação excelentes. Cantei "Automne" e "Rencontre" de Faure e "Lê charme" de Chanson.

\section{Sexta-feira, 26 maio 1939}

$\left(118^{\mathrm{a}}\right.$ aula)

Cantei "amour que veux tu de moi", "La vie anterieure"; desta vez não dei "Revê de printemps.

Amour que veux tu de moi

$(1632+1687)$

Dona Vera gostou muito da maneira que eu estudei, corrigiu-me o seguinte:
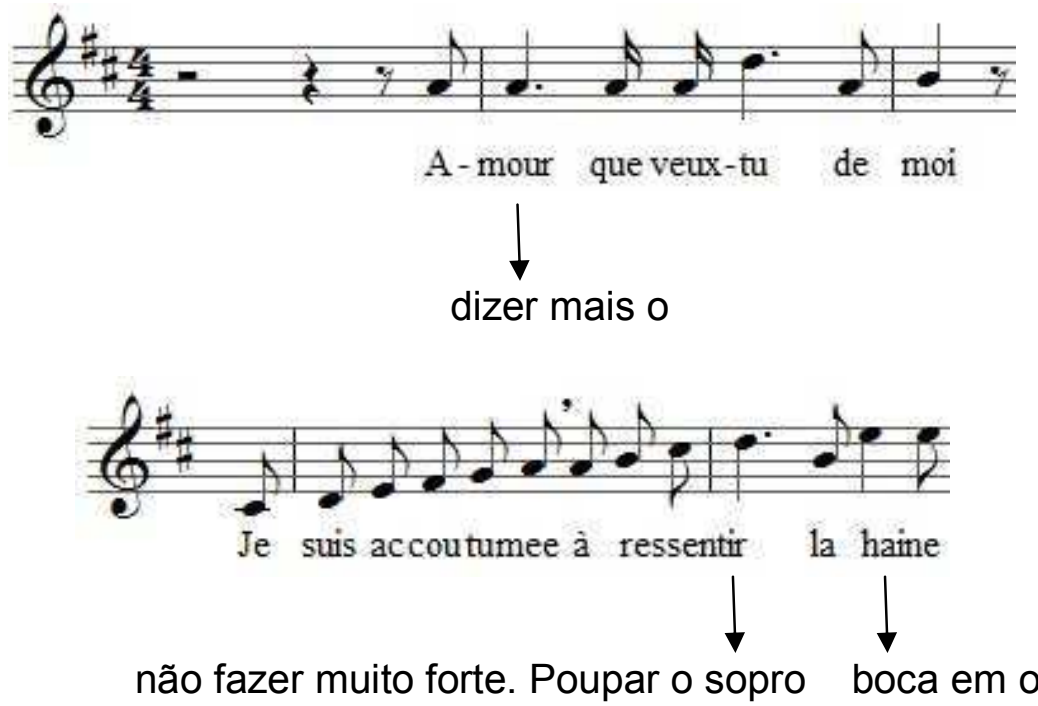

As duas primeiras vezes, devem ser cantadas com raiva, como quem diz: "deixa-me em paz"... A ultima como uma suplica, triste e pianíssimo. 
La vie anterieure

$(1848+\quad$ (Duparc)

Dona Vera achou que, como primeira vez foi muito bem. As respirações bem estudadas, salvo uma ou duas que foram corrigidas.
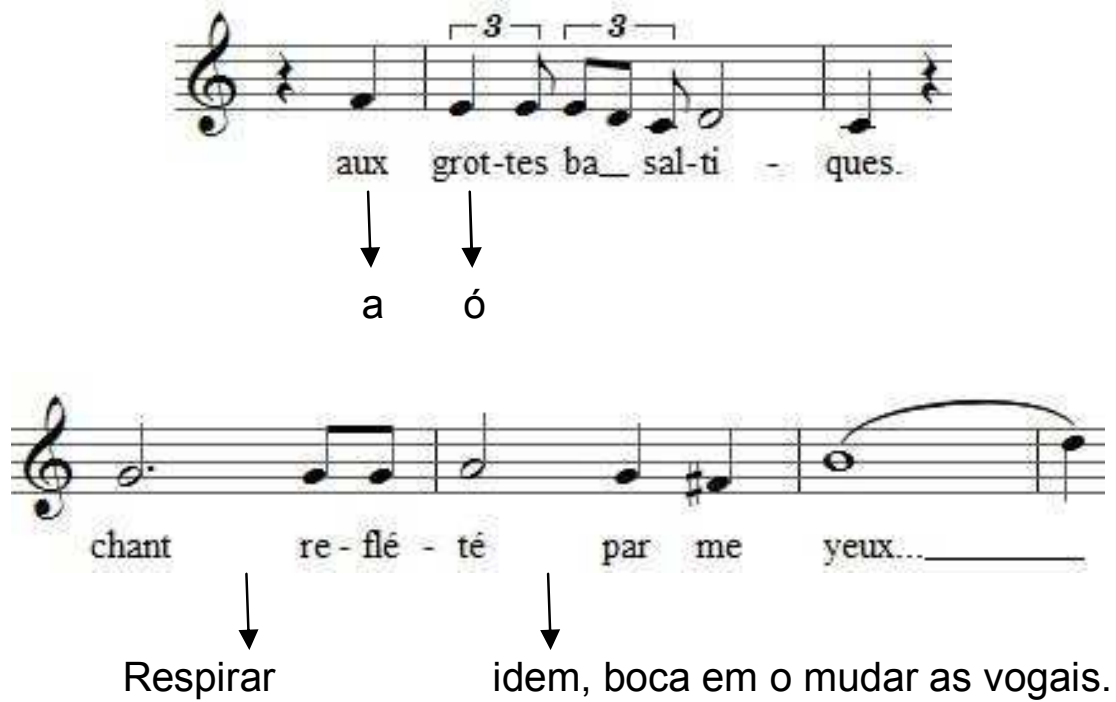

Terça-feira, 30 maio 1939

$\left(119^{\mathrm{a}}\right.$ aula $)$

Tive hoje uma lição interessantíssima e agradável em todos os pontos de vista. Levei tudo muito bem sabido e Dona Vera ficou satisfeita. Cantei "Ammour que veux tu de moi" que está quase bom. Depois de "La vieauterieure" que foi otimamente e em seguida dei "Le loleu indicateur". A interpretação desta musica tem que ser muito mais variada visto ser muito repetida.

Le Poleau Indicateur

$(1797+1828) \quad$ (Schubert)

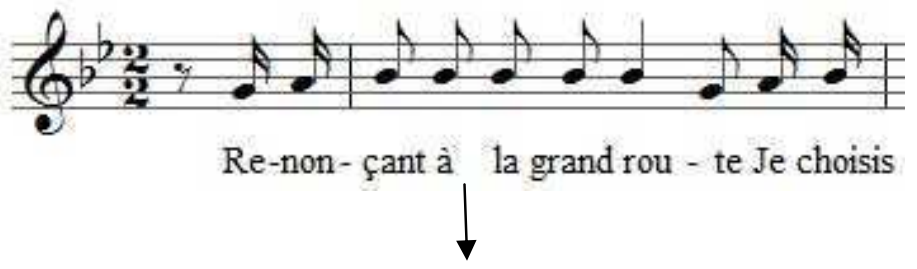

fazer toda a frase mais piano e bem plana.

Dona Vera gostou muito de uma respiração que eu inventei; diz ela que foi uma noidade muito bem feita. 


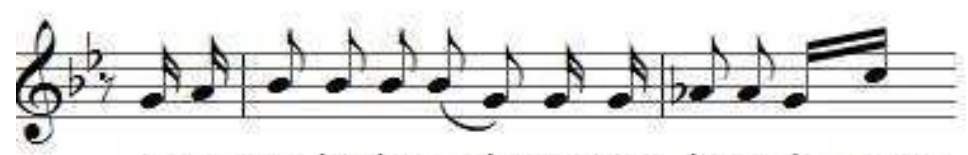

A-tra-versles dur roche-rs_Dans la ne-i- ge,etc.
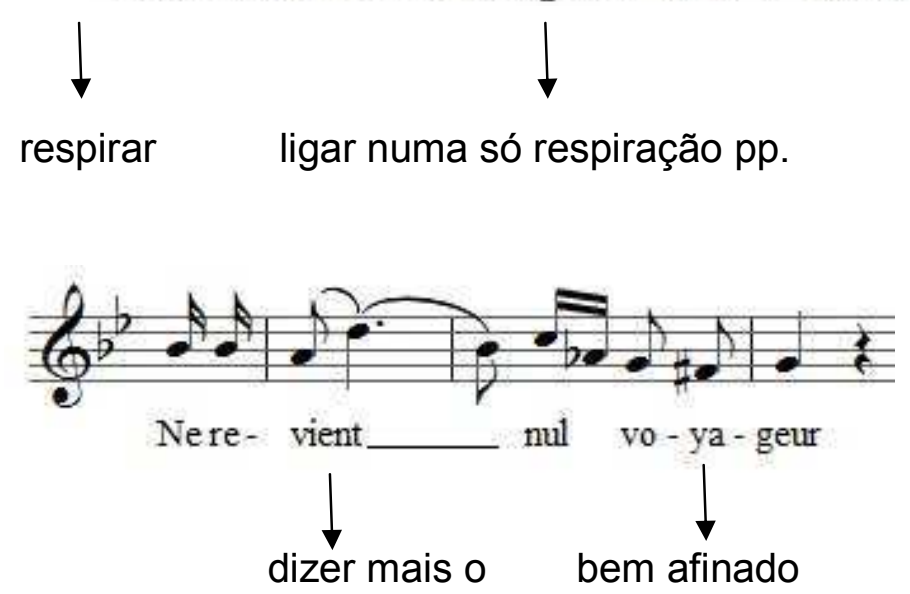

La vie auterieure

$(1848+\quad$ (Duparc)

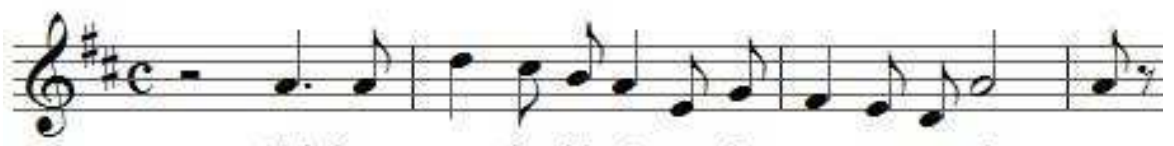

J'ai long-tempsha-bi-té sous de vas-tes por-ti - ques
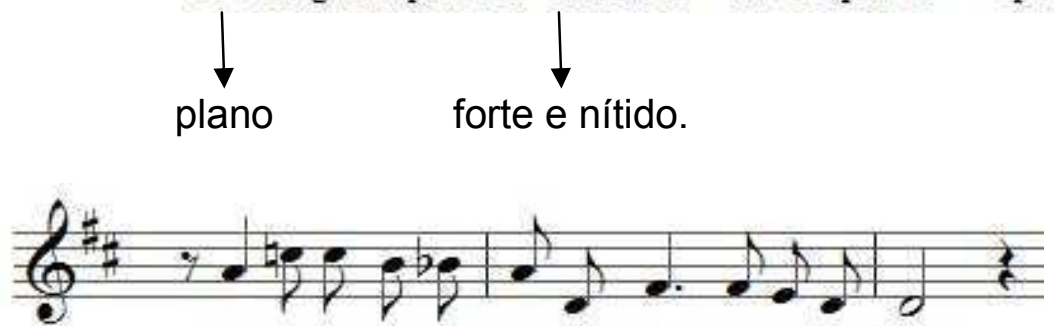

Que le so-leis ma-rins teignaient de mi-le feux,

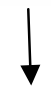

não fazer pontuado, prestar muita atenção!

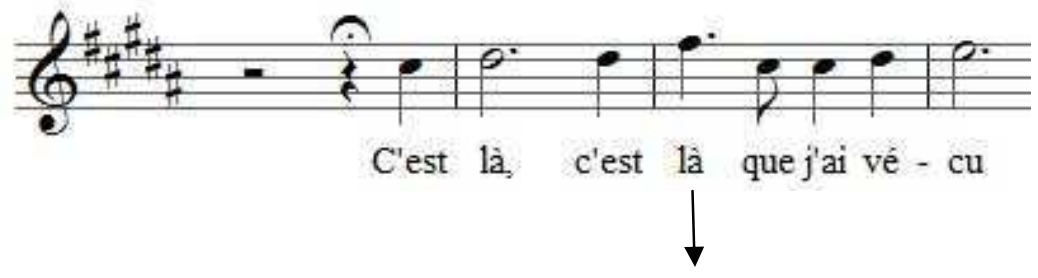

dizer com 2 II e voz bem aberta e sonora. 


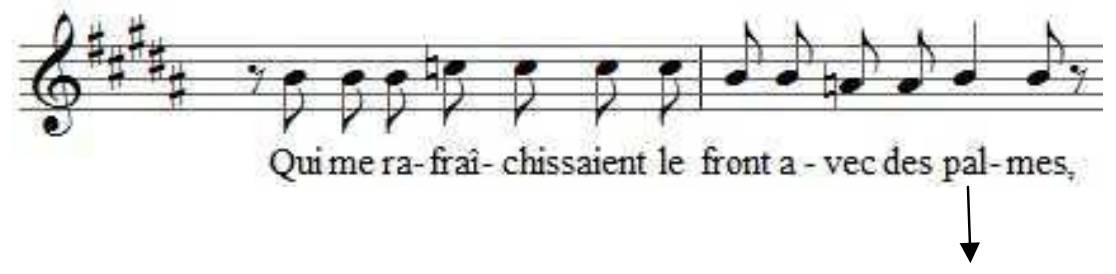

sentir bem o balanço das palmas.

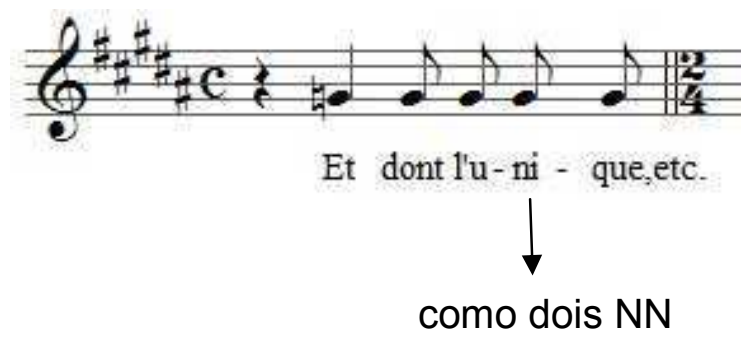

\section{Quarta-feira, 7 junho 1939}

$\left(120^{\mathrm{a}}\right.$ aula $)$

O exercício dos grupetos, Dona Vera quer que eu faça o possível para emitir todas as vogais da mesma forma e na altura de i.

\section{Sexta-feira, 9 junho 1939}

$\left(121^{\mathrm{a}}\right.$ aula $)$

"Amour que veux lu de moi", "La vie anterieure" e "Poleau indicateur" foram as musicas que apresentei à lição de hoje.

Le Poleau indicateur

$(1797+1828)$

( Schubert)

Dona Vera acha que eu estou dando muita vida a está musica. A voz está muito quente e a interpretação está como uma pessoa esperançosa de realizar um ideal. O sentido das palavras é bem diverso: é um homem desiludido que nada mais espera de seu amor; um homem descrente e desolado que, de tanto desalento planeja um suicídio. Para eu melhor sentir todas essas coisas devo fazer o andamento mais calmo e sem acelerar. 
Sábado, 10 Junho, 1939

$\left(122^{\mathrm{a}}\right.$. aula)

A lição de hoje foi interessantíssima e eu aproveitei demais por ter dado uma hora justa acompanhada pelo Salles.

La vie anterieure

$(1848+$

(Duparc)

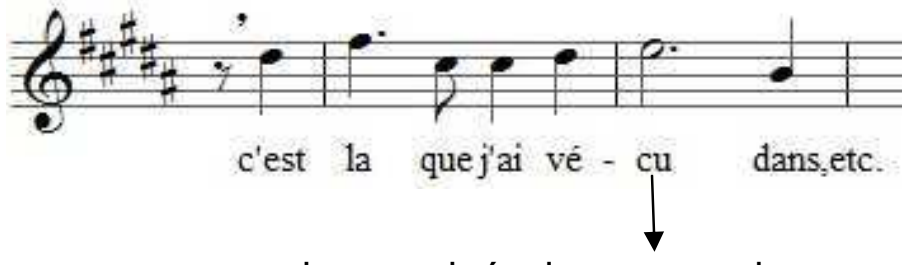

bem maleável e crescendo

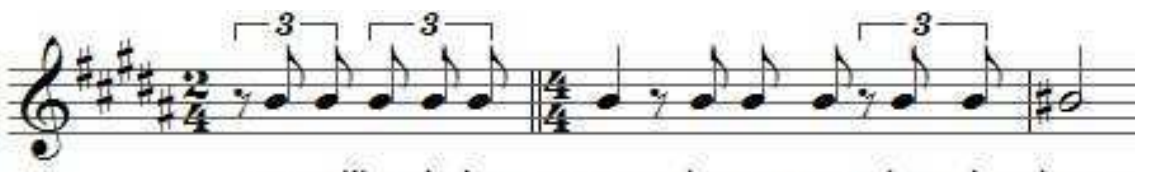

Au milieu de l'a - zur, des va-gues, des splen-deurs,<smiles>[3H][13CH3]</smiles>

iniciar a frase com voz bem de cabeça, para que saia clara e, para haver igualdade em plenitude, deve se fazer anasalado.

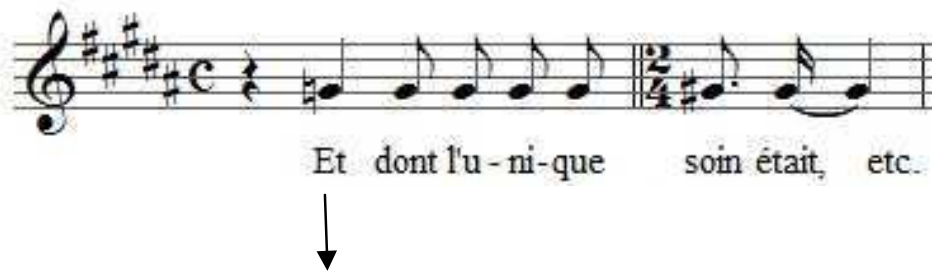

fazer muito diferente; a voz mais quente para que não seja infantil.

Les Berceaux precisa fazer a $1^{*}$ frase bem balançada.

Le poleau indicateur

$(1797+1828) \quad$ (Schubert)

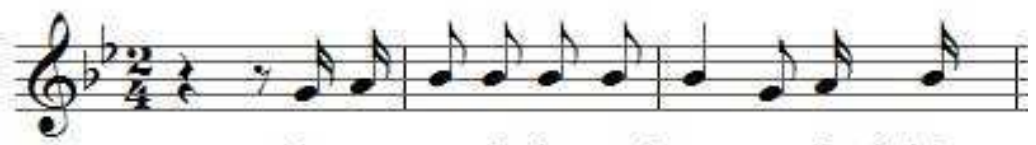

Re non çant à la grand rou - te Je choisis,etc.

fazer ligado e crescer um pouco nas notas repetidas. 


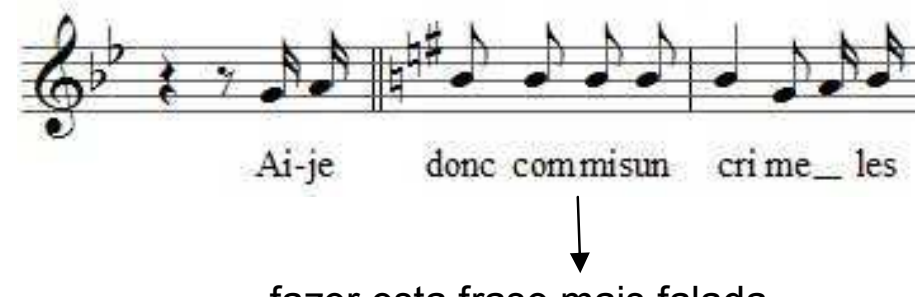

fazer esta frase mais falada.

Terça-feira, 13 junho 1939

$\left(123^{a}\right.$. aula)

Da aula de hoje nada tenho a anotar.

\section{Quinta-feira, 15 junho 1939}

$\left(124^{\mathrm{a}}\right.$. aula)

Fui muitíssimo bem na aula de hoje.

\section{Quinta-feira, 15 junho, 1939}

Foi hoje a 3a audição que Dona Vera deu. Cantei com desembaraço, com respiração calma e boa interpretação, "Les berceaux", Le poleau indicateur" e "La vie anterieure".

Vocalizes

I. Deve-se emitir com muito bocejo; língua pousada, flexibilidades e todas as vogais iguais.

II. A $1^{\text {a }}$. terça sentindo bem a vibração dos maxilares, na 28 abrir bem a boca em o, altura flexível.

III. Por muita altura na nota grave, apoio na $3^{*}$ nota e não perder a altura no um

IV. Para adquirir altura, é bom estudar em ou; queixo bem para trás, bem de cabeça, mexer as orelhas.

V. Deve-se demorar pouco na $1^{*}$ nota, aplicar os yy; mexer com a língua para suspender o véu palatino. As notas saem pelos olhos.

Vocalizes 

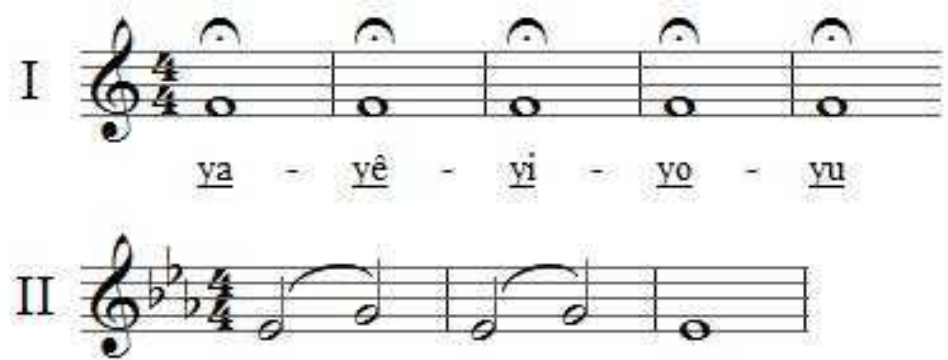

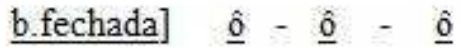

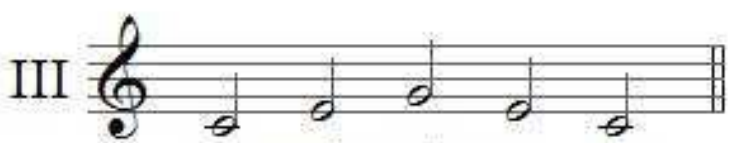

$\underline{\mathrm{ma}}-\underline{\mathrm{mê}}-\underline{\mathrm{mi}}-\underline{\mathrm{mo}}-\underline{\mathrm{mu}}$

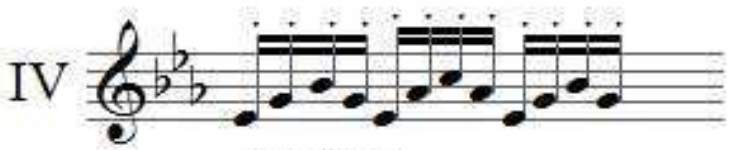

o-u- - piqué

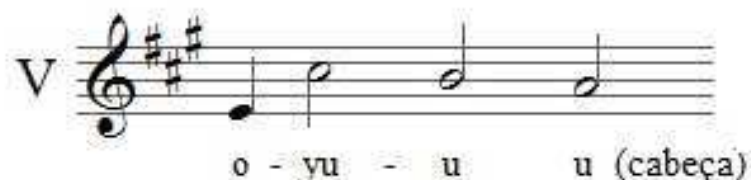

VI. Para ser maleável convém dizer sem cantar 4 vezes osmoy-mo. Marcar 8 em 8. Apoio.

VII. Prepara-se da mesma maneira que o 6. Quando chegar ao muito agudo fazer bem leve. Estes 2 ultimos fazer sem $\mathrm{M}$.

VIII. Marcar bem de 4 em 4. Altura nos graves, queixo para atrás, muita altura e apoio nos agudos.

IX. Marcar de 4 em 4, na altura de ou, o pique bem leve, bem situado.

X. O difícil é fazer sem sopro as notas agudas. Para estudar é bom aplicar os yyy.

XI. Fazer bem leves os grupelos, em cada nota separada, por o queixo para trás. Pode se fazer em $\mathrm{O}$. 

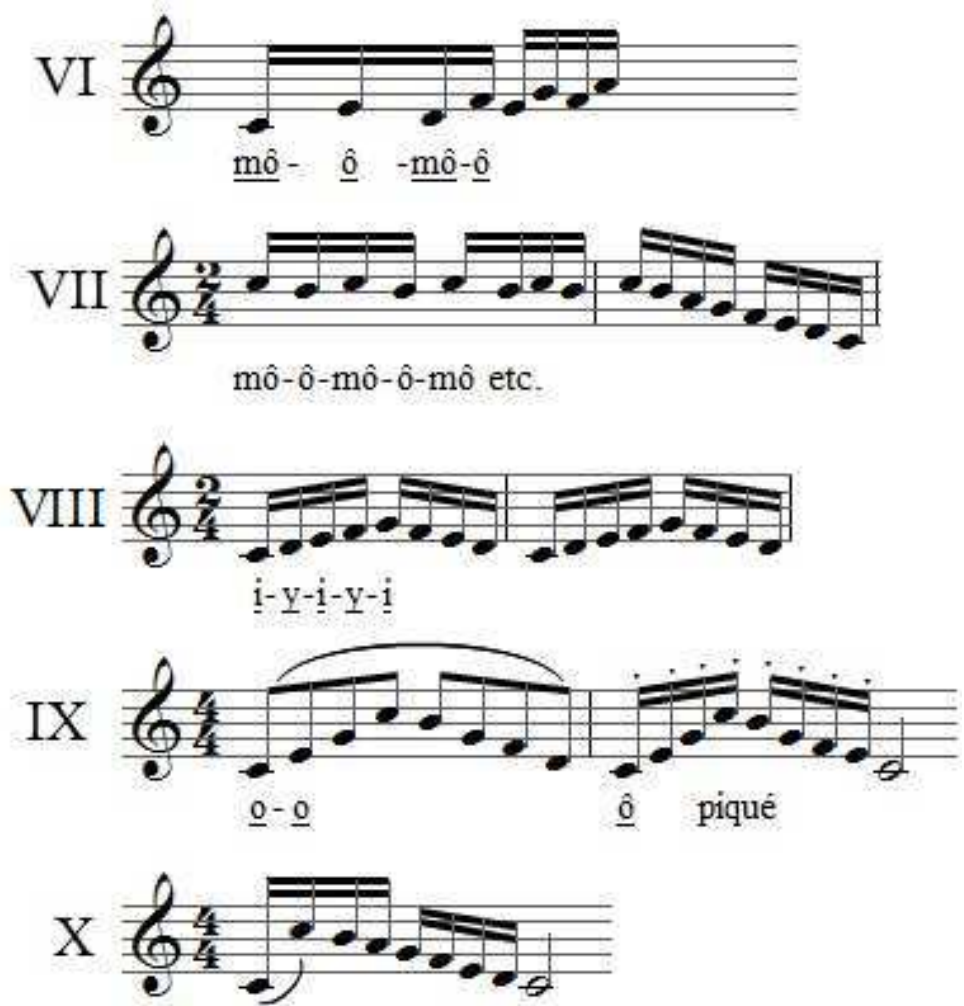

$\underline{0}-\underline{y}-\underline{0}$

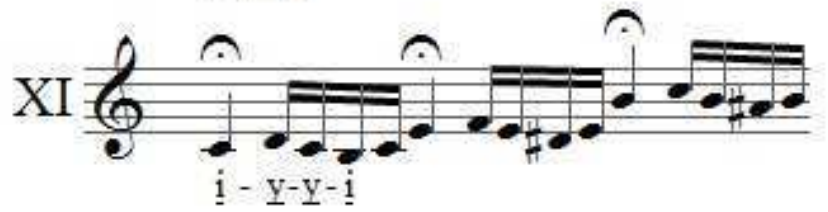

XII. Muita altura na $1^{*}$ nota y na $2^{*}$ alargamento.

XIII. Fazer bem marcado. Para impedir que o queixo vá para a frente, estuda-se com 1 lápis na boca.

XIV. Tomar cuidado para não haver queda de laringe nos graves.

XV. Muita altura, tranqüilidade nas respirações.

XVI. Bem calmo, respirar pelo nariz. Não mastigar os graves. Mudar as vogais.

XVII. Muita altura especialmente no penúltimo dó, para preparar o agudo $\mathrm{O}$. 

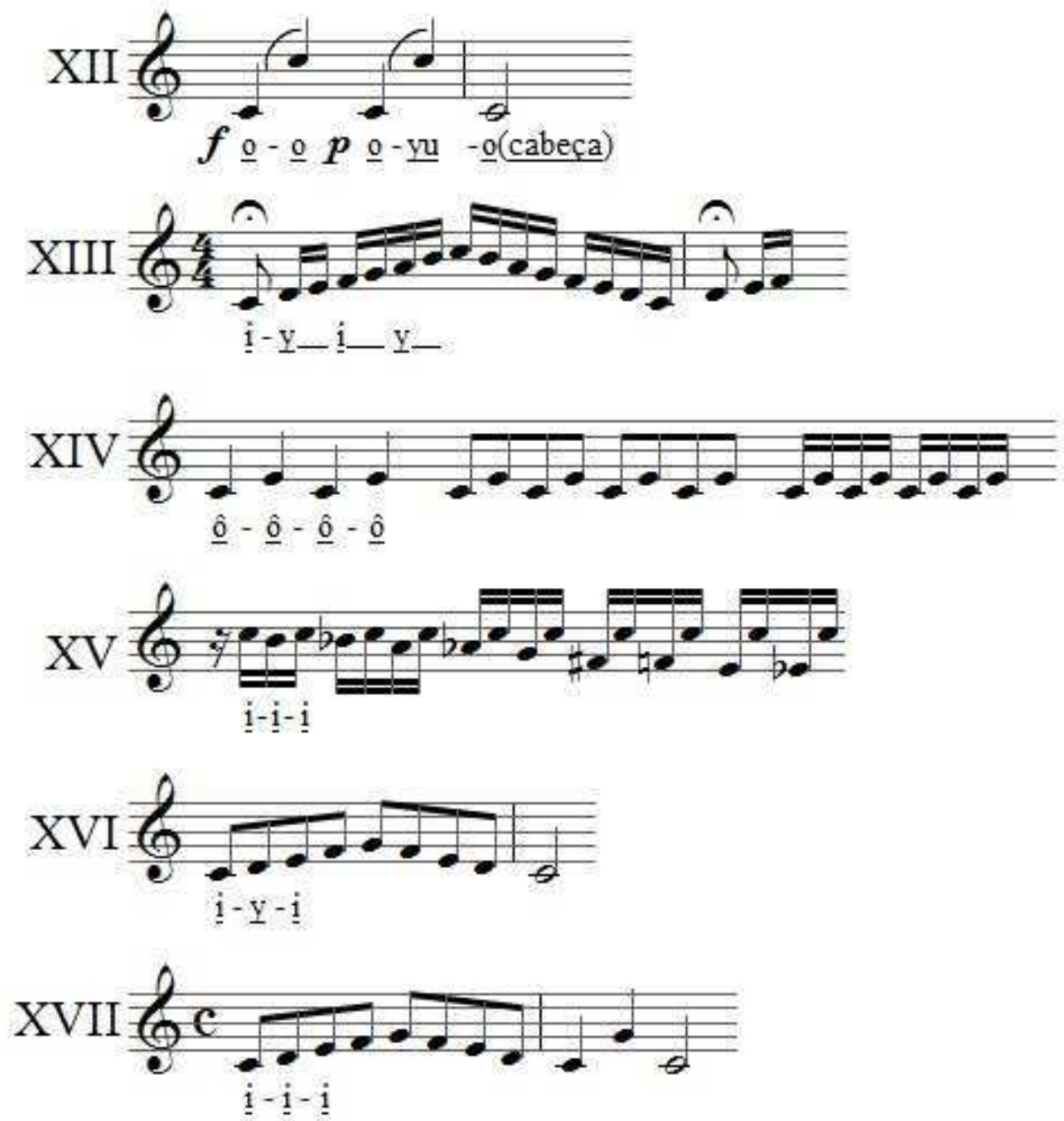

XVIII. Começar com o som pontudo. < o tórax, altura.

XIX. Começar de cabeça, pontudo, ir < com altura, alargamento < >

XX. Esse é mais preparação para os dos arpejos. Por altura e fazer ás vezes ou.

XXI. Fazer bem leves os agudos. Altura nos graves, queixo para trás.

XXII. marcar de 3 em $3,1^{*}$ vez forte, $2^{*}$ vez piano, $3^{*}$ de cabeça, isto é pique e numa só respiração.

XXIII. Começar bem pontudo, bem ritmado, até largar o trinado p. deve ficar solto. 

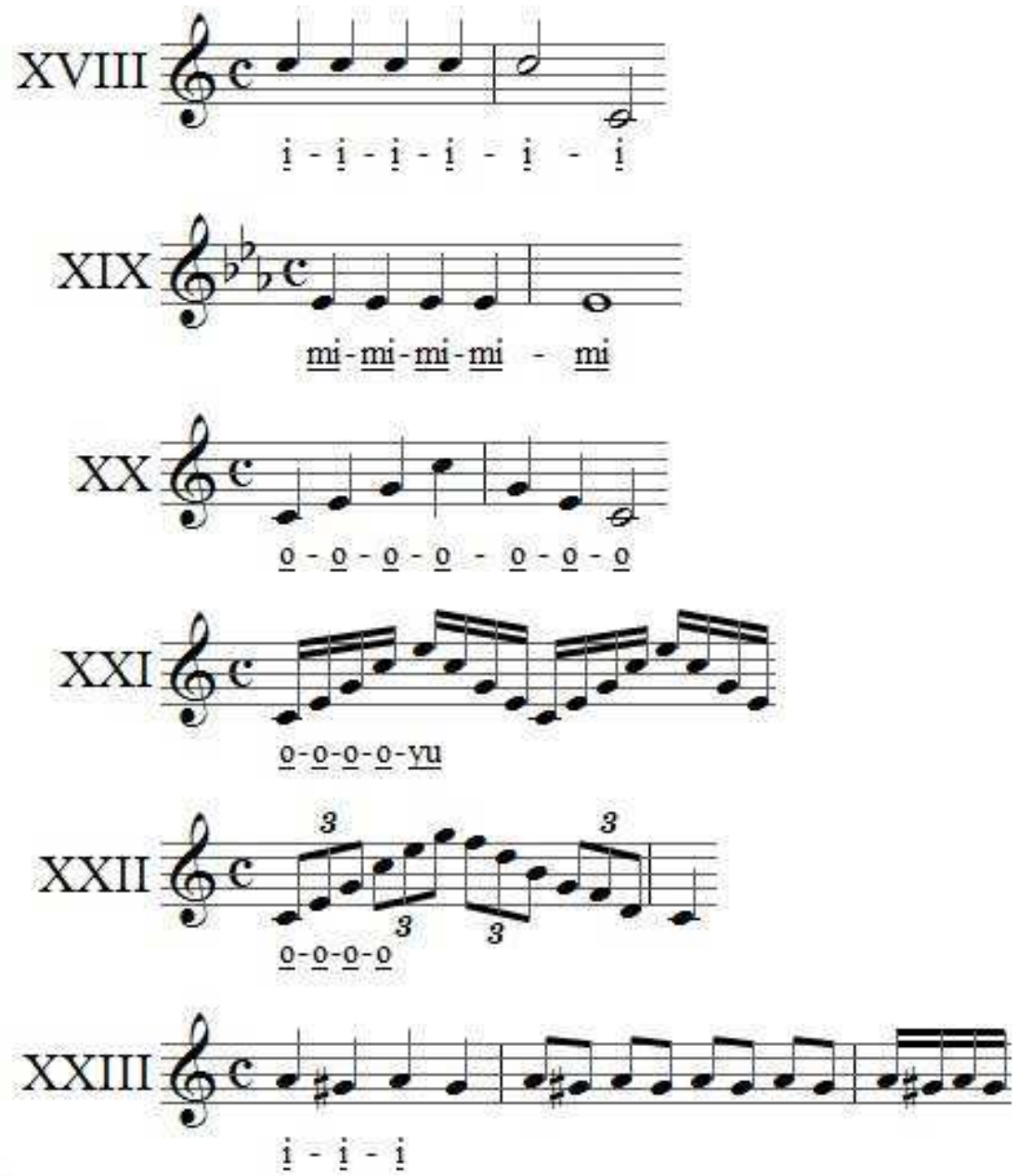
MUSICAS ESTUDADAS E DECORADAS

NOS ANOS DE 1937 - 1938 - 1939.

J. B. Pergolesi - Que me suis-je la fougère (10/11/37)

Paisiello - Nel cor più nom mi sento $(16 / 11 / 37)$

A.Caldara - Comme raggio di sol (10/12/37)

Scarlatti - Sento nel core (5/1/1938)

Caccini - Amarilli (26/1/38)

Durante - Vergin tutto amor (31/1/38)

Marcello - Quella fiamma che m'accende (14/3/38)

Caldara - Sebben crudele (14/3/38)

Fauré - Les berceaux (21/3/38)

Beethoven - Apaisement (9/4/38)

Fauré - Le secret (20/4/38)

Schumann - Quand Mai (23/4/38)

L'auore, La rose $(23 / 4 / 38)$

Quand je regard etc (23/4/38)

Schumann - Mes Larmes (27/4/38)

Campra - Chanson du papillon (30/4/38)

Fauré - Rencontre (9/5/38)

Fauré - Toujour (16/5/38)

"Adieu - (16/5/38)

Schumann - Au Loin (2/6/38)

Mozart - Alleluia (2/6/38)

Fauré - Clair de Lune (2/6/38)

Lully - Air des Songes (13/6/38)

Mozart - Voi che sapete (7/7/38)

Monteverdi - Lasciatemi morire (11/7/38)

Mozart - Non so più (15/7/38)

Fauré - Les roses d’Ispahan (26/7/38)

Fauré - Prière (13/9/38)

Au bord de L'eau (13/9/38)

Fauré - Splleen (20/9/38)

Brahms - D`amours eternelles (30/9/38)

Fauré - Chanson du Pecheur (30/9/38)

Fauré - Tristesse (27/10/38)

Hasse - Ritornerai fra poco (14/10/38)

Schumann - Ai-je fait un rêve (21/10/38)

Gluck - O del mio dolce ardor (11/11/38)

Pergolesi - Se tu m'ami (16/11/38)

Schumann - Ah! Viens calmer ma fièvre (16/11/38)

Schumann- Tu veux lire dans mes jeux (9/12/38)

Schumann - L'aube rayonne (13/12/38)

Debussy - Romance (13/12 38)

Schumann - O pleurs amers! $(21 / 12 / 38)$ 
1939

Haendel - Ch'io m'ai vi possa (3/3/39)

Schubert - La poste (3/3/39)

Haendel - Recitativo e ária del Rinaldo (10/3/39)

Martín - Plaisir d’amour (17/3/39)

Duparc - Chanson triste (17/3/39)

Schubert - Bonne nuit (14/4/39)

Scarlatti - Se Florindo è fedele (28/4/39)

Chauson - Le charme (5/5/39)

Lulli - Amour que veux tu de moi (19/5/39)

Schubert - Rêve du printemps (19/5/39)

Duparc - La vie anterieure (26/5/39)

Schubert - Le poleau indicateur (30/5/39)

La Grande Game

Lili Lehmann

Deve se fazer uma vez por dia.

Ex 283 (Escala de Lili Lehmann)

Cantar lentamente; respirar pelo nariz; muita flexibilidade, muita altura!!! Pode-se aplicar as palavras "ILLUSION FIDELITÉ - DIVINITE - ALLELUIA - FELICIDADE, etc" Melhor ainda é aplicar as palavras das músicas.

Dona Vera (Rio) 27-1577

(SP) 4.1665

Salles $5-1040$

Guarnieri $\quad 4-2758$

Suza Lima 8-4524

Cultura Artística 2-1787

Antonio Chechin 2-1535

Augusto Perth -5-3710

Cella 2 
Autorizo a reprodução e divulgação total ou parcial deste trabalho, por qualquer meio convencional ou eletrônico, para fins de estudo e pesquisa desde que citada a fonte.

\section{Catalogação na publicação \\ Serviço de Biblioteca e Documentação \\ Escola de Comunicações e Artes da Universidade de São Paulo}

Vasconcelos, Emerson Adriano Gomes

Magdalena Lébeis e o registro sistemático de um processo pedagógico: resgate histórico e análises iniciais / Emerson Adriano Gomes Vasconcelos - São Paulo:

E. A. G. Vasconcelos, 2012.

199 p. : il.

Dissertação (Mestrado) - Escola de Comunicações e Artes / Universidade de São Paulo.

Orientadora: Silvia Maria Pires Cabrera Berg

1. Pedagogia vocal 2. Processos pedagógicos 3. Técnica vocal 4. Interpretação 5. Canção de câmara brasileira 6. Lébeis, Magdalena, 1912-1984 7. Janacópulos, Vera, 1892-1955 I. Berg, Silvia Maria Pires Cabrera II. Título 